Universidad deValladolid

PROGRAMA DE DOCTORADO EN INGENIERÍA QUÍMICA Y

AMBIENTAL

TESIS DOCTORAL:

\title{
THERMAL HYDROLYSIS PRE-TREATMENT TO ENHANCE ANAEROBIC DIGESTION OF WASTE ACTIVATED SLUDGE. OPTIMIZATION OF OPERATING CONDITIONS AND EVALUATION OF ALTERNATIVE SCHEMES
}

Presentada por IEVA SAPKAITE para optar al grado de

Doctora por la Universidad de Valladolid

Dirigida por:

Sara Isabel Pérez Elvira 

Universidad deValladolid

PROGRAMA DE DOCTORADO EN INGENIERÍA QUÍMICA Y

AMBIENTAL

TESIS DOCTORAL:

\title{
PRETRATAMIENTO POR HIDRÓLISIS TÉRMICA PARA MEJORAR LA DIGESTIÓN ANAEROBIA DE LODO ACTIVADO. OPTIMIZACIÓN DE LAS CONDICIONES DE OPERACIÓN Y EVALUACIÓN DE ESQUEMAS ALTERNATIVOS
}

\author{
Presentada por IEVA SAPKAITE para \\ optar al grado de
}

Doctora por la Universidad de Valladolid

Dirigida por:

Sara Isabel Pérez Elvira 

Memoria para optar al grado de Doctor, con Mención Doctor Internacional, presentada por la Ingeniera Ambiental:

leva Sapkaite

Siendo tutora en la Universidad de Valladolid:

Sara Isabel Pérez Elvira

Y investigadora responsable en Universidad de la República (Montevideo, Uruguay):

Prof. Titular Liliana Borzacconi

Valladolid, a __ de ___ de 2017 

Universidad deValladolid

\section{Secretaría}

La presente tesis doctoral queda registrada en el folio número del correspondiente libro de registro número

Valladolid, a de de 2017

Fdo. El encargado del registro. 



\author{
Dra. Sara Isabel Pérez Elvira \\ Profesor Contratado Doctor \\ Departamento de Ingeniería Química y Tecnología del \\ Medio Ambiente \\ Universidad de Valladolid
}

Certifica que:

IEVA SAPKAITE ha realizado bajo su dirección el trabajo "Thermal hydrolysis pre-treatment to enhance anaerobic digestion of waste activated sludge. Optimization of operating conditions and evaluation of alternative schemes", en el Departamento de Ingeniería Química y Tecnología del Medio Ambiente de la Escuela de Ingenierías Industriales de la Universidad de Valladolid. Considerando que dicho trabajo reúne los requisitos para ser presentado como Tesis Doctoral, expresan su conformidad con dicha presentación.

Valladolid, a de de 2017

Fdo. Sara Isabel Pérez Elvira 

Reunido el tribunal que ha juzgado la Tesis Doctoral Titulada: "Thermal hydrolysis pre-treatment to enhance anaerobic digestion of waste activated sludge. Optimization of operating conditions and evaluation of alternative schemes" presentada por la Ingeniera Ambiental leva Sapkaite, y en cumplimiento de lo establecido por el Real Decreto 99/2011 de 28 de enero de 2011 acuerda conceder por la calificación de

Valladolid, a de de 2017

PRESIDENTE

SECRETARIO

VOCAL 



\section{INDICE DE CONTENIDOS}

Resumen I

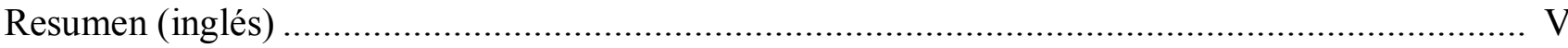

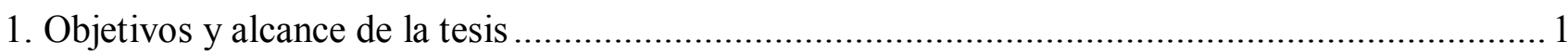

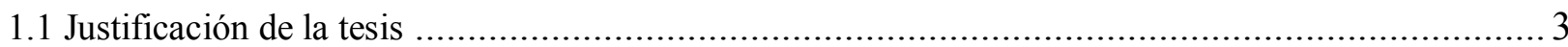

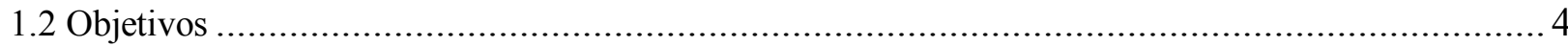

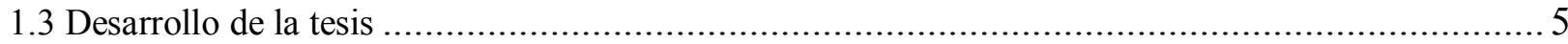

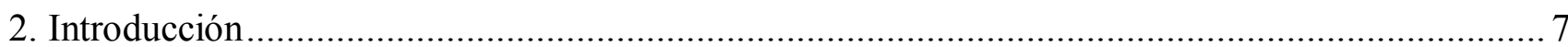

2.1 Tratamiento de aguas residuales y lodos: situación global ................................................ 9

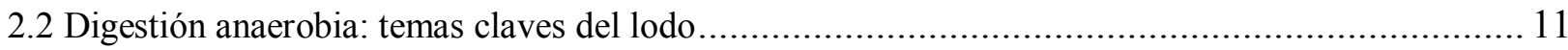

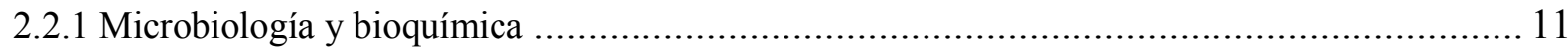

2.2.2 Digestión anaerobia del lodo secundario ......................................................................... 12

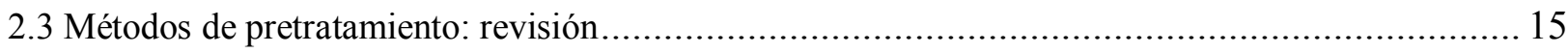

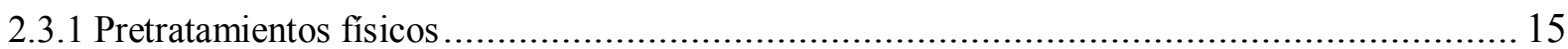

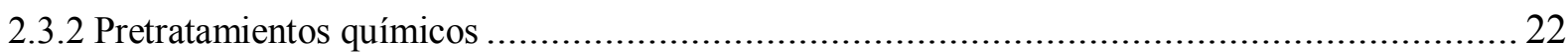

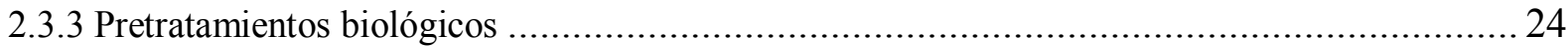

2.3.4 Discusión sobre los métodos de pretratamiento ......................................................... 25

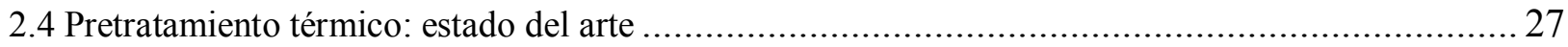

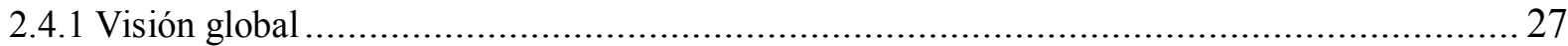

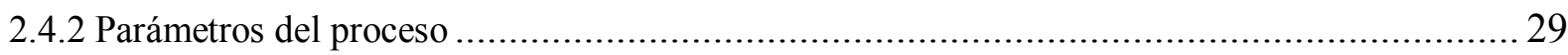

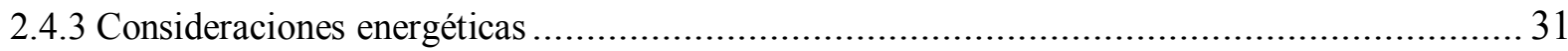

2.4.4 Influencia del pretratamiento térmico sobre la solubilización del lodo y sobre la producción de

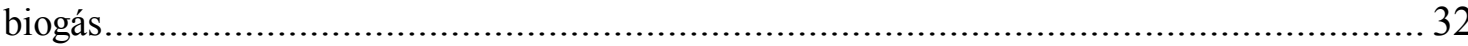

2.4.5 Influencia del pretratamiento térmico sobre la deshidratación y la viscosidad del lodo ............ 33

2.4.6 Influencia del pre-tratamiento térmico sobre el tiempo de residencia en digestión anaerobia.... 34

2.4.7 Pretratamientos térmicos a escala de laboratorio: revisión ........................................... 35

2.4.8 Procesos comerciales de pretratamiento térmico: revisión ............................................. 42

2.4.9 Discusión general acerca de la aplicabilidad de la hidrólisis térmica ................................. 50

2.5 Métodos alternativos al esquema convencional de hidrólisis térmica ...................................... 56

2.5.1 Nueva configuración de proceso: Hidrólisis Térmica Intermedia ........................................ 56

2.5.2 Alternativa al tratamiento térmico: Pretratamiento de explosión de gas ............................... 58

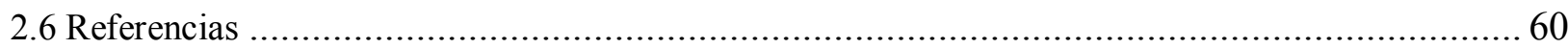

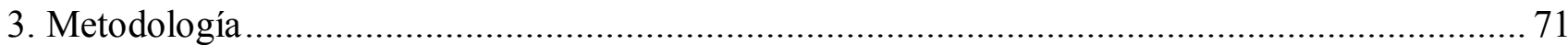




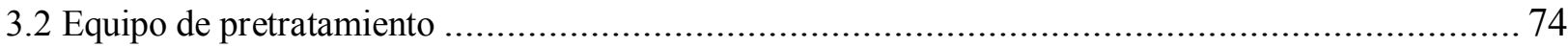

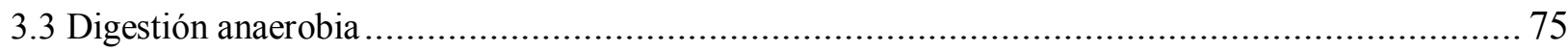

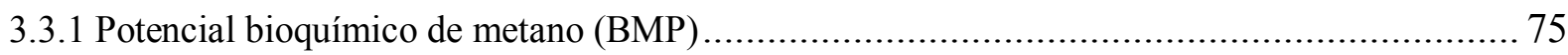

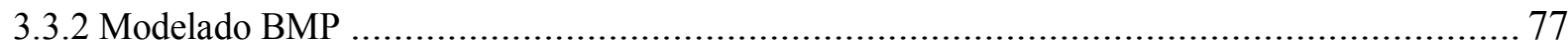

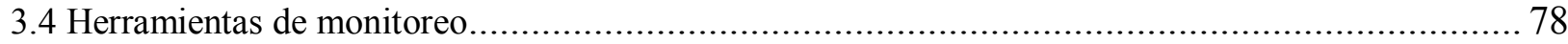

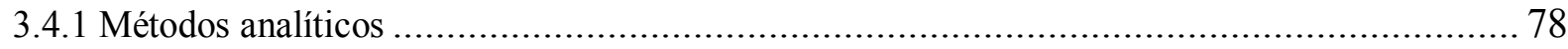

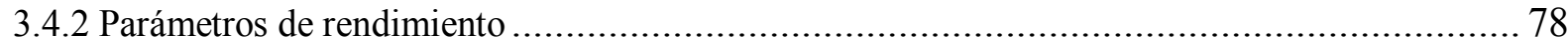

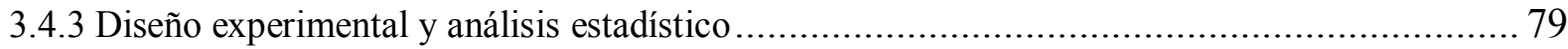

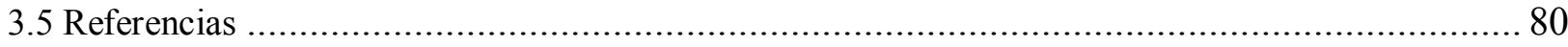

4. Evaluation of thermal steam-explosion key operation factors to optimize biogas production from

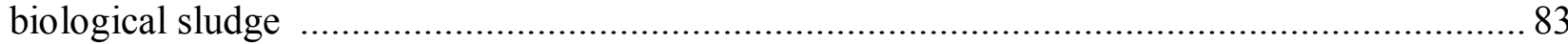

5. Optimization of a thermal hydrolysis process for sludge pre-treatment ................................. 95

6. Thermal hydrolysis of sludge over a limiting temperature. Effect on prediction parameters....... 103

7. Separate digestion of liquid and solid fractions of thermally pretreated secondary sludge. Assessment and global evaluation

8. Assessment of "gas explosion" pre-treatment on the anaerobic digestion efficiency in terms of methane production

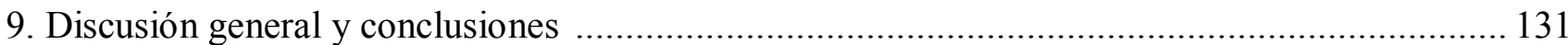

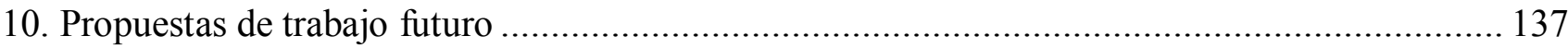

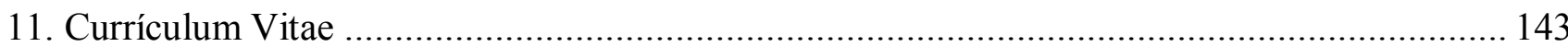




\section{TABLE OF CONTENTS}

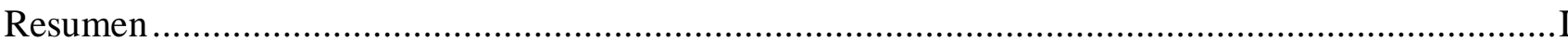

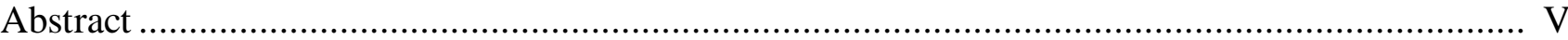

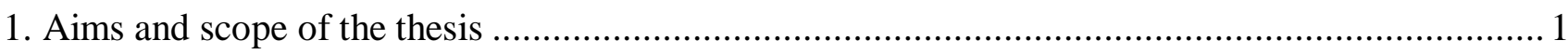

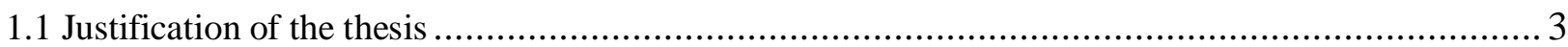

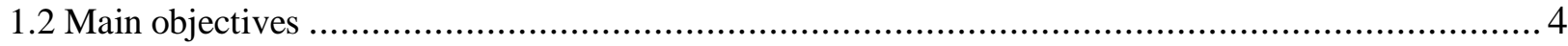

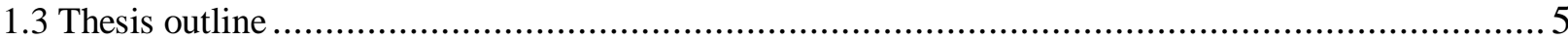

2. Introduction

2.1 Wastewater and sludge treatment: global situation.................................................... 9

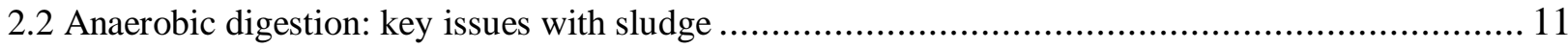

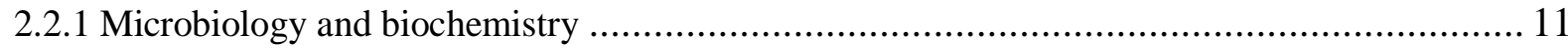

2.2.2 Anaerobic digestion of waste activated sludge ........................................................ 12

2.3 Sludge pre-treatment processes: a review ................................................................... 15

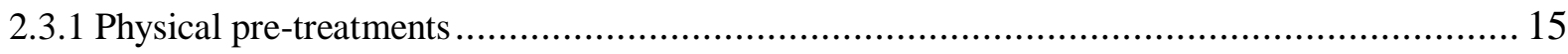

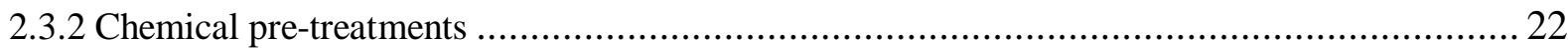

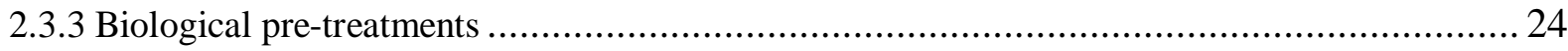

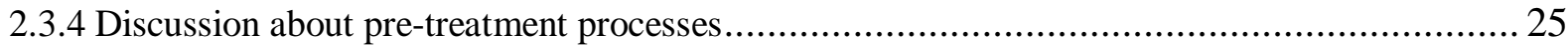

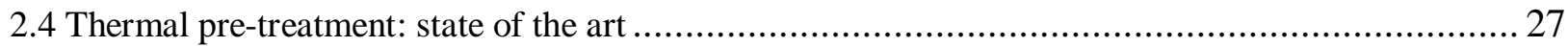

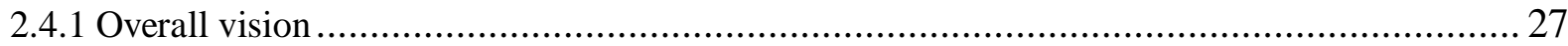

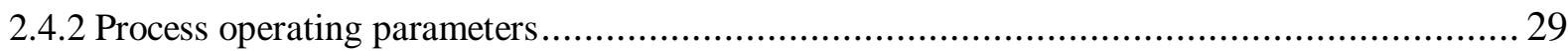

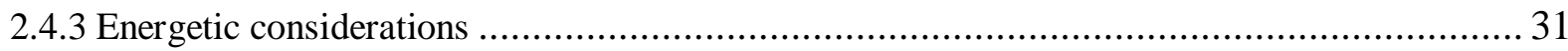

2.4.4 Influence of thermal pre-treatment on sludge solubilisation and biogas production................ 32

2.4.5 Influence of thermal pre-treatment on sludge dewaterability and viscosity ......................... 33

2.4.6 Influence of thermal pre-treatment on anaerobic digestion retention time ............................ 34

2.4.7 Laboratory scale thermal pre-treatments: a review..................................................... 35

2.4.8 Commercial thermal pre-treatment processes: a review .............................................. 42

2.4.9 General discussion of thermal hydrolysis applicability ............................................. 50

2.5 Alternative approaches to conventional thermal hydrolysis schemes ....................................... 56

2.5.1 A novel process configuration: Intermediate Thermal Hydrolysis .................................... 56

2.5.2 A variation to the thermal process: Gas explosion pre-treatment ...................................... 58

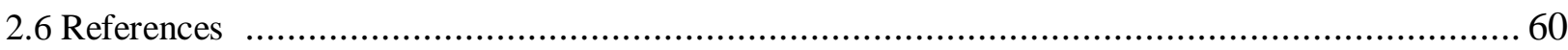

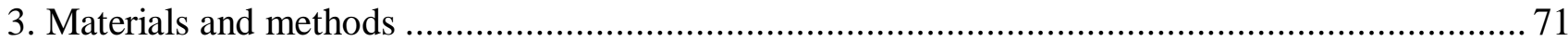

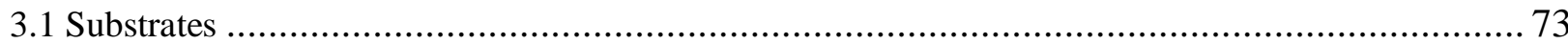




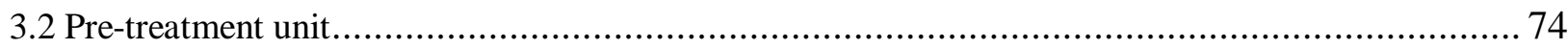

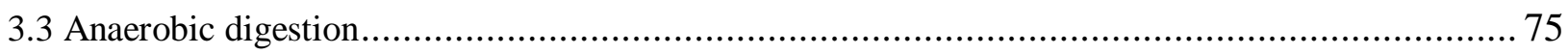

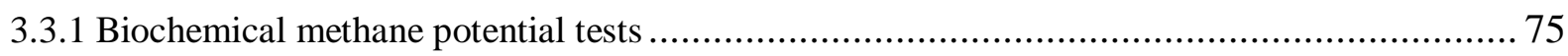

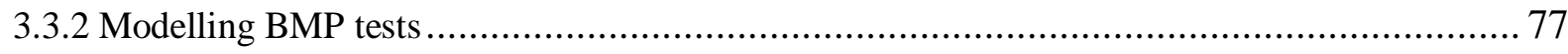

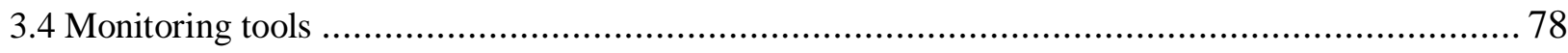

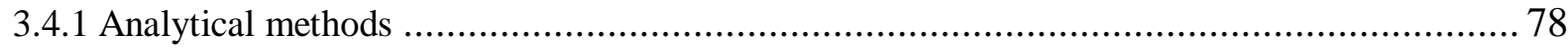

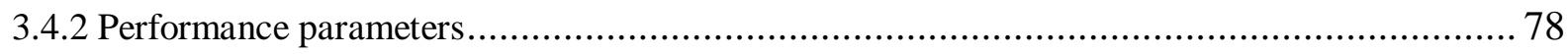

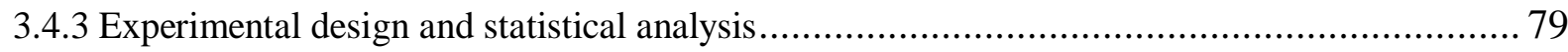

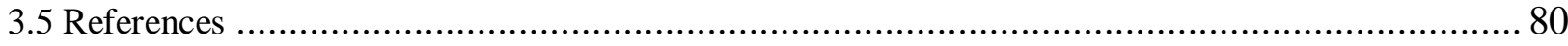

4. Evaluation of thermal steam-explosion key operation factors to optimize biogas production from

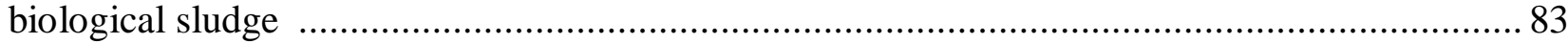

5. Optimization of a thermal hydrolysis process for sludge pre-treatment ................................. 95

6. Thermal hydrolysis of sludge over a limiting temperature. Effect on prediction parameters....... 103

7. Separate digestion of liquid and solid fractions of thermally pretreated secondary sludge. Assessment and global evaluation

8. Assessment of "gas explosion" pre-treatment on the anaerobic digestion efficiency in terms of methane production

9. General discussion and conclusions

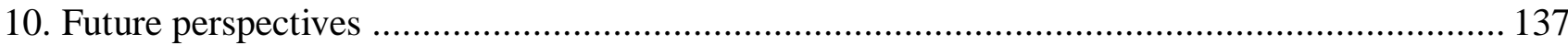

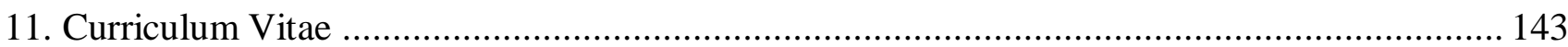


En la actualidad se generan grandes cantidades de sólidos durante el proceso de tratamiento de aguas residuales, y debido a que los requisitos de protección ambiental se están volviendo cada vez más estrictos, la gestión de estos lodos se está convirtiendo en un gran problema.

La digestión anaerobia (DA) de lodos es considerado el tratamiento más adecuado debido a su escaso impacto ambiental, su alto potencial de recuperación de energía en forma de biogás (60 $70 \%$ de metano) y a la reducción de la cantidad de biosólidos a eliminar. Sin embargo, debido a la biodegradabilidad compleja del lodo secundario (en la cual la fase limitante es la hidrólisis), las plantas de tratamiento de aguas residuales se ven obligadas a reevaluar sus estrategias de gestión de lodos. Han sido varios los métodos de pretratamiento previo a digestión desarrollados e investigados para mejorar la solubilización y desintegración de estos lodos. Todos ellos inducen la solubilización de materia particulada compleja (transferencia de las partículas a la fracción líquida), haciendo que ésta sea consumida más rápidamente durante la digestión anaerobia, aumentando el volumen de biogás producido y disminuyendo la cantidad final de biosólidos.

De entre todos ellos, el pretratamiento térmico (o hidrólisis térmica) representa la alternativa más rentable y fiable a escala industrial. Sus principales ventajas son: una atractiva integración energética del proceso completo y una mejora en la calidad y gestión de los biosólidos producidos después de la digestión. Ambos factores afectan positivamente el coste de operación de la planta de tratamiento de aguas residuales (ya que el balance energético neto podría resultar positivo), y los lodos hidrolizados (esterilizados a temperaturas elevadas) cumplen con los requerimientos de la Agencia de Protección Ambiental (EPA) para lodos de Clase A.

Los diferentes procesos comerciales de hidrólisis térmica que han sido desarrollados compiten entre sí a la hora de realizar el pretratamiento en las condiciones y configuraciones óptimas, con el fin de alcanzar su compromiso particular entre rendimiento y coste. En este contexto, la optimización de las condiciones de operación, la configuración del proceso global, y el esquema de integración energética son lógicamente los tres temas más importantes explorados hoy en día en el campo de la hidrólisis térmica.

En este escenario, esta tesis se centra concretamente en la identificación de los diferentes factores que afectan el rendimiento de generación de metano tras el pretratamiento térmico y la selección de aquellas condiciones de operación óptimas que desempeñan una función clave en la economía del proceso, con el fin de consolidar la hidrólisis térmica como una tecnología rentable para la digestión anaerobia de lodos activos.

Los objetivos y esquema del desarrollo de la tesis se presentan en el Capítulo 1, mientras que en el Capítulo 2 aparece un análisis general de actualidad sobre la digestión de lodos, las tecnologías de 
pretratamiento y la hidrólisis térmica, discutiendo y comparando el escenario actual para revisar los principales problemas en relación a la tesis.

La metodología experimental se resume en el Capítulo 3, donde se describen los equipos en que se han llevado a cabo la hidrólisis y la digestión, así como las herramientas de monitoreo y los parámetros claves del proceso. Se ha dedicado una sección especial al diseño experimental y al análisis estadístico como herramienta principal de optimización.

En el Capítulo 4 se evalúo la influencia de diferentes combinaciones de temperatura-tiempodescompresión (variando entre $110-180^{\circ} \mathrm{C}, 5-50 \mathrm{~min}, 1-3$ etapas de descompresión) sobre la degradación anaerobia de lodo secundario. Todas las condiciones probadas presentaron una mayor producción de metano en los valores finales para el día 30 en comparación con el control (muestra no tratada), mostrando un incremento desde el $20 \%$ (a $110^{\circ} \mathrm{C}$ ) hasta el $40 \%$ (a $180^{\circ} \mathrm{C}$ ). Sin embargo, únicamente la temperatura mostró una influencia positiva en la producción de metano, si bien en condiciones extremas de hidrólisis térmica $\left(180^{\circ} \mathrm{C}, \mathrm{t}>30 \mathrm{~min}\right)$, la fase de latencia aumentó drásticamente hasta 3.5 días, probablemente debido a la formación de compuestos recalcitrantes. Tanto el tiempo de reacción como las etapas de descompresión no mostraron influencia significativa. La hidrólisis térmica a tiempos cortos $(5 \mathrm{~min})$ y a temperaturas moderadas $\left(145^{\circ} \mathrm{C}\right)$ parece ser muy atractiva desde el punto de vista de la degradación, ya que presentó un aumento de la producción de metano similar al obtenido a $180^{\circ} \mathrm{C}$, sin influenciar negativamente en la fase de latencia (a diferencia de lo sucedido a $180^{\circ} \mathrm{C}$ ).

Las condiciones óptimas para la hidrólisis térmica del lodo activo fueron determinadas a través de un diseño experimental de tipo Box-Behnken y analizadas usando el Método de Superficies de Respuesta (RSM). Estos resultados se muestran en el Capítulo 5. Se generó un modelo cuadrático polinomial para comparar el rendimiento del proceso para 15 combinaciones de las variables de operación estudiadas (temperatura, tiempo y modo de descompresión). El análisis estadístico de los datos corroboró que la producción de metano y la solubilización se vieron significativamente afectadas por la temperatura de pretratamiento, mientras que el tiempo de reacción y las repetitivas descompresiones tuvieron una menor influencia. La producción máxima de metano (362 mL $\left.\mathrm{CH}_{4} / \mathrm{gVS}_{\mathrm{fed}}\right)$ se obtuvo para las condiciones óptimas de pretratamiento $\left(163^{\circ} \mathrm{C}, 35 \mathrm{~min}\right.$ y 1 etapa de descompresión) mientras que la solubilización máxima del $41 \%$ se obtuvo en las condiciones más altas de tratamiento $\left(180^{\circ} \mathrm{C}, 49 \min\right.$ y 1 etapa de descompresión). La superposición de las curvas de contorno de solubilización y de producción de metano mostró que no existen condiciones óptimas de hidrólisis que optimicen ambas variables de forma simultánea. Durante el pretratamiento de alta 
severidad (temperaturas altas y tiempos largos), la solubilización aumentó bruscamente, mientras que la producción de metano mostró el comportamiento opuesto, indicando la posible formación de material soluble pero no biodegradable. Tras la optimización de los parámetros operativos, el rango de condiciones óptimas estimadas de hidrólisis térmica para mejorar más de un 50\% la digestión del lodo secundario (de 220 a $360 \mathrm{~mL} \mathrm{CH}_{4} / \mathrm{g} \mathrm{VS}_{\text {fed}}$ ) fueron: $140-170^{\circ} \mathrm{C}$ temperatura de calentamiento, 5 - 35 min tiempo de reacción, y una descompresión súbita.

En el Capítulo 6 se evaluó el efecto de sobrepasar la temperatura de pretratamiento térmico por encima del rango estudiado en los capítulos anteriores. Sólo el pretratamiento a $150^{\circ} \mathrm{C}$ presentó un aumento en la producción de metano de hasta un $30 \%$ (de 254 to $327 \mathrm{~mL} \mathrm{CH}_{4} / \mathrm{g} \mathrm{VS}_{\text {fed }}$ ) en comparación con la muestra no tratada. La producción de metano a partir de fangos pretratados a una temperatura de $200^{\circ} \mathrm{C}$ se mantuvo casi constante. Por otro lado, se obtuvo una fase de latencia muy marcada (mayor de 8 días) a las temperaturas más altas, lo que confirma cambios evidentes en el comportamiento de la degradación anaerobia del lodo. De modo contrario a la producción de metano, la eficiencia de solubilización aumentó proporcional al aumento de temperatura, y por lo tanto con la severidad del pretratamiento, mostrando una vez más que la solubilización no es un parámetro fiable para evaluar el rendimiento de la hidrolisis térmica.

Los Capítulos 7 y 8 se dedicaron a la evaluación de esquemas alternativos que combinan la hidrólisis térmica y la digestión anaerobia.

El primer enfoque (Capítulo 7) trató la digestión separada de las fracciones líquida y sólida del lodo secundario pretratado térmicamente $\left(170^{\circ} \mathrm{C}, 50 \mathrm{~min}\right)$. Este estudio mostró que el $30 \%$ de la materia orgánica particulada se liberó durante el pretratamiento, con el consiguiente incremento de

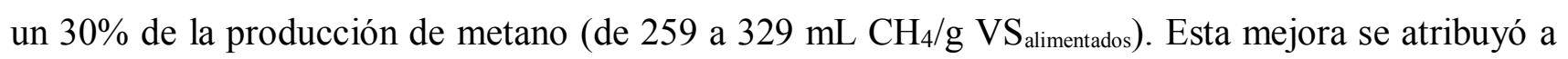
la fracción líquida, ya que la biodegradabilidad de la fracción sólida permaneció constante después del pretratamiento. Los balances de masa mostraron que el 34\% de los sólidos volátiles fueron solubilizados en la fracción líquida, generando casi el 50\% del metano total producido, con una cinética mucho más rápida que la presentada por la fracción sólida. Estos resultados apoyan la hipótesis de una digestión separada de las fracciones líquida y sólida del lodo pretratado térmicamente, ya que resultaría en la disminución del volumen de digestión a la mitad mientras se duplica la producción de metano por kilogramo de lodo llevado a digestión.

El segundo enfoque, presentado en el Capítulo 8, se trata de una alternativa al tratamiento térmico: un pretratamiento de presión o "explosión de gas", sin calentamiento. $\mathrm{CO}_{2} \mathrm{y} \mathrm{CH}_{4}$ fueron los dos gases utilizados para la presurización del lodo. Las variables evaluadas del proceso fueron 
presión, tiempo y modo de descompresión ( 5 - 8 bar, 1 - 10 minutos, modo de descompresión lento o súbito y diferentes etapas de descompresión), y se evaluaron dos tipos de lodos: lodo activo y lodo digerido. Todas las condiciones de pretratamiento evaluadas mejoraron escasamente o directamente no mejoraron ni la solubilización de lodos ni la producción de metano durante la subsiguiente digestión anaerobia. Tampoco se obtuvieron diferencias significativas entre las combinaciones de las variables de pretratamiento o el gas utilizado.

La discusión general de los resultados obtenidos en la presente tesis se presenta en el Capítulo 9 junto con una conclusión clara: no existe un óptimo generalizado para todo tipo de lodo ni para todo caso de estudio, y por tanto la propuesta óptima de un esquema de tratamiento dependerá de las regulaciones (disposición, energía, etc.), los valores de mercado actuales (los costes de capital, gestión y energía) y los requisitos específicos de cada situación particular (renovación de una planta de tratamiento de aguas residuales existente o nueva construcción, necesidades de digestión, opciones de gestión disponibles, etc.).

Finalmente, en el Capítulo 10 se proponen perspectivas futuras, con el fin de llenar los huecos existentes y poder llevar a cabo una valoración global más completa del proceso combinado de pretratamiento térmico y digestión anaerobia de lodos de depuradora. 
Huge amounts of solids are generated during sewage treatment process, while sludge disposal is becoming the bottleneck due to increasingly strict environmental protection laws and standards.

Anaerobic digestion ( $\mathrm{AD}$ ) of sludge is considered as the most suitable method for sludge treatment due to its limited environmental impact, high potential for energy recovery as biogas $(60-$ $70 \%$ methane), and reduction in the amount of biosolids to be disposed. However, due to the complex biodegradability of waste activated sludge (rate-limiting hydrolysis step), wastewater treatment plants are forced to re-evaluate their sludge management strategies.

A number of pre-treatment methods prior to AD have been developed and investigated in order to improve and enhance the solubilisation and disintegration of sludge solids. They all induce the solubilisation of complex particulate matter (a transfer from the particles to the liquid fraction), so it is more rapidly and completely consumed during anaerobic digestion, increasing the volume of biogas produced, and decreasing the amount of solids to be disposed. Among all them, at industrial scale, the thermal pre-treatment represents the most profitable and reliable alternative. The main drivers for the use of thermal hydrolysis are an attractive energy integration of the full process and an improvement on quality and disposal of the biosolids produced after digestion. Both factors positively affect the operating cost of the treatment plant, as the net energy balance could be positive and the hydrolysed sludge (sterilized at elevated temperatures) comply with the Environmental Protection Agency (EPA) requirements for Class A sludge.

Different existing commercial thermal hydrolysis processes compete to perform the pretreatment in the optimum conditions and configurations, in order to reach their particular compromise between performance and cost. With this background, the optimization of the operating conditions, process configurations and integration scheme are reasonably the three mayor issues explored nowadays in the field of thermal hydrolysis.

Specifically, this thesis focuses on the identification of the factors which affect methane yield through thermal pre-treatment, and the selection of those optimal operating conditions that play a key role on the process economics in order to consolidate thermal pre-treatment process as a costeffective technology for anaerobic digestion of waste activated sludge.

The objectives and outline of the thesis are presented in Chapter 1, while a general review on digestion of sludge, pre-treatment technologies and thermal hydrolysis is submitted in Chapter 2, discussing and comparing the current scenario in order to revise the main issues related to the thesis. In Chapter 3, the experimental methodology was summarized, describing the equipment for hydrolysis and digestion, and the monitoring tools. The key operating and performance parameters 
were also described, and a special section was dedicated to the experimental design and statistical analysis as the main tool for screening and optimization.

In Chapter 4, the influence of different temperature-time-flash combinations (ranging: 110 $180^{\circ} \mathrm{C}, 5-50 \mathrm{~min}, 1-3$ re-flashing) on the anaerobic degradation of secondary sludge through biochemical methane potential (BMP) tests was assessed. All the conditions tested presented higher methane production in the final values for day 30 compared to the control (untreated sample), from $20 \%$ improvement (at $110^{\circ} \mathrm{C}$ ) to $40 \%$ (at $180^{\circ} \mathrm{C}$ ). However, only temperature showed a positive influence on the methane production, although at extreme thermal hydrolysis conditions $\left(180^{\circ} \mathrm{C}\right)$, the lag phase increased dramatically up to 3.5 days for a treatment severity $\left(\log \mathrm{R}_{0}\right)$ over $3\left(180^{\circ} \mathrm{C}, \mathrm{t}>\right.$ $30 \mathrm{~min}$ ), probably due to the formation of recalcitrant compounds. Time and re-flashing exhibited no significant influence. Finally, thermal steam-explosion at short operating times ( $5 \mathrm{~min}$ ) and moderate temperatures $\left(145^{\circ} \mathrm{C}\right)$ seemed to be very attractive from a degradation point of view thus presenting a methane production enhancement similar to the one obtained at $180^{\circ} \mathrm{C}$ and without negative influence of the lag phase.

Through statistically guided Box-Behnken experimental design and Response Surface Method, the optimum conditions for thermal hydrolysis of waste activated sludge were determined and are presented in Chapter 5. A quadratic polynomial model was generated to compare the process performance (solubilisation and methane increase during $\mathrm{AD}$ ) for the 15 different combinations of operating conditions (temperature, time and decompression mode). The statistical analysis performed exhibited again that methane production and solubility were significantly affected by pre-treatment temperature, while the reaction time and decompression mode had a lower incidence. A maximum methane production of $362 \mathrm{mLCH}_{4} / \mathrm{gVS}_{\text {fed }}$ was predicted at the optimum conditions $\left(163^{\circ} \mathrm{C}, 35 \mathrm{~min}\right.$ and 1 flash) while a maximum solubilisation of $41 \%$ was achieved at higher operating conditions $\left(180^{\circ} \mathrm{C}, 49 \mathrm{~min}\right.$ and $\left.1 \mathrm{flash}\right)$. Contour plot curves of solubilisation and methane production were superimposed to exhibit that there is no joint optimum thermal hydrolysis conditions for both variables. During high intensity pre-treatment (high temperature and long times), the solubility increased sharply while the methane production exhibited the opposite behaviour, indicating the possible formation of some soluble but non-biodegradable materials. Based on the operating parameters optimization, the estimated optimal thermal hydrolysis conditions to enhance of sewage sludge digestion (exceeding 50\% increases, from 220 to $360 \mathrm{~mL} \mathrm{CH} 4 / \mathrm{g} \mathrm{VS}_{\text {fed }}$ ) were: $140-170^{\circ} \mathrm{C}$ heating temperature, 5 - $35 \mathrm{~min}$ residence time, and one sudden decompression. 
The effect of exceeding thermal pre-treatment temperature over the evaluated range was investigated in Chapter 6. Only pre-treatment at $150^{\circ} \mathrm{C}$ presented higher methane production up to $30 \%$ (from 254 to $327 \mathrm{~mL} \mathrm{CH}_{4} / \mathrm{g} \mathrm{VS}_{\text {fed }}$ ) compared to the untreated sample. Methane production at pre-treatment temperature of $200^{\circ} \mathrm{C}$ remained almost constant. Moreover, a very marked lag phase (larger than 8 days) also appeared at higher temperatures confirming evident changes in sludge degradability behaviour. Contrary to methane production, solubilisation efficiency increased proportional to the temperature rise, and therefore with the severity of the pre-treatment, exhibiting once again that solubilisation is not a trustworthy parameter to evaluate the pre-treatment performance. In our specific case, some soluble but non biodegradable compounds such as melanoidins could be produced at high pre-treatment temperatures.

Chapters 7 and 8 were dedicated to evaluate alternative schemes combining thermal hydrolysis and anaerobic digestion.

The first approach (Chapter 7) was the separate digestion of the liquid and solid fractions from thermally pre-treated $\left(170^{\circ} \mathrm{C}, 50 \mathrm{~min}\right)$ secondary sludge. This study exhibited that $30 \%$ of the particulate organic matter was released during the pre-treatment, correspondingly increasing the methane production of that particulate matter by $30 \%$ (from 259 to $329 \mathrm{~mL} \mathrm{CH} / \mathrm{g}$ VSfed). The responsible of this enhancement was the liquid fraction, as the biodegradability of the solid fraction remained constant after the pre-treatment. Mass balances showed that $34 \%$ of the volatile solids were released to the liquid fraction, generating nearly $50 \%$ of the total methane produced, with much faster kinetics compared to the solid fraction. These results supported the hypothesis of a separate liquid-solid digestion of thermally pre-treated sludge, which would result in decreasing the digestion volume to half while duplicating the methane productivity per kilogram of sludge fed to digestion.

The second approach, presented in Chapter 8, was an alternative to the thermal pre-treatment: a pressure pre-treatment ("gas explosion" performed with $\mathrm{CO}_{2}$ and $\mathrm{CH}_{4}$ ) without heating. $\mathrm{CO}_{2}$ and $\mathrm{CH}_{4}$ were the gases used for the sludge pressurization. The process variables were pressure, time and decompression mode (ranging: 5 - 8bar, 1 - 10 minutes, slow or sudden decompression mode, and re-flasing), and two types of sludge were assessed: waste activated sludge and digested sludge. All the pre-treatments improved poorly or did not improve neither sludge solubilisation nor methane production during subsequent anaerobic digestion. No significant differences between pre-treatment variables combinations or gas used were obtained.

The general discussion of the results obtained in the present thesis was summarized in Chapter 9 together with the specific consideration: there is no joint optimum for any type of sludge and case 
study, and the proposal of the optimum scheme will depend on regulations (disposal, energy and etc.), current market values (capital, disposal and energy costs), and on the specific requirements of the particular situation (renovation of existing WWTPs or new construction, digestion needs, available disposal options and etc.).

A final Chapter 10 proposes the future perspectives that can be considered for further insight in order to fill out the existing niches for thermal pre-treatment and anaerobic digestion process enrichment. 
CHAPTER 1

Aims and scope of the thesis 



\subsection{Justification of the thesis}

Nowadays, wastewater treatment plants (WWTP) are widely implemented in most municipalities and industries to reduce harmful wastewater discharge into receiving water bodies. However, due to increasing contaminant load caused by population growth, increasingly strict environmental protection laws and standards for water quality and reclaimed water, huge amounts of solids are generated during sewage treatment process. The most commonly applied sludge disposal methods (incineration, landfill and land application) are, to the same, progressively subjected to more social and legal constraints. Therefore, more efficient sludge treatments (composting, aerobic digestion and anaerobic digestion) are applied in order to reduce sludge quantity in the WWTPs.

Anaerobic digestion $(\mathrm{AD})$ of sludge is considered a critical sludge treatment option that can fit into the frameworks of new regulations, reducing the overall amount of sludge to be disposed and, moreover, generating energy rich biogas (60 - 70\% methane) that can be valorised energetically. Even so, the problems arise due to the complex biodegradability of waste activated sludge: slow degradation with a high retention time; still large quantities of biosolids produced, because of low biodegradability; huge operating volume of traditional digesters due to the high water content in sludge, which is difficult to remove; incomplete eliminations of pathogens, thereby, digested sludge is considered as potential source of pathogens. Those circumstances have forced wastewater treatment plants to re-evaluate their sludge management strategies.

A number of pre-treatment methods prior to AD have been developed and investigated in order to improve and enhance the solubilisation and disintegration of sludge solids. They all induce the solubilisation of complex particulate matter (a transfer from the particles to the liquid fraction), so it is more rapidly and completely consumed during anaerobic digestion, increasing the volume of biogas produced, and decreasing the amount of solids to be disposed. Pre-treatment methods that have been shown to have a positive effect include: physical (high pressure homogenization, ultrasonic, grinding-stirred ball mills, lysis centrifuge, focused-pulses, thermal pre-treatment), chemical (ozonization, acid or alkaline hydrolysis) and biological (bacterial and enzyme hydrolysis) techniques. Among all them, thermal pre-treatment has emerged as the most commercialised pretreatment choice, due to its techno-economic benefits: increase in organic loading rates to the anaerobic digesters, higher biogas yield, improved digester's hydrodynamic, reduced biosolids volume, biosolids pasteurization to Environmental Protection Agency (EPA) Class A standards.

Alongside these advantages, a key benefit of thermal hydrolysis is related to the process economics and operating costs. The energy needed to operate a thermal pre-treatment system is heat (not electricity), produced by cogeneration from the biogas. The overall profitability of the process is 
therefore directly related to the global energy integration of the system (pre-treatment and digestion), and is optimized when all the biogas is used to produce energy in a gas engine and the residual heat from cogeneration is enough to run the thermal process (no biogas burning or heat purchase). This optimization is only possible for continuous systems that use live steam heating.

With this background, the optimization of the operating conditions, process configurations and integration scheme are reasonably the three mayor issues explored nowadays in the field of thermal hydrolysis. In fact, different existing commercial thermal hydrolysis processes compete to perform pre-treatment in the most advantageous conditions and configurations, thus encumbering the assessment of that global equilibrium between maximum biogas production and minimum energy requirement.

This situation justifies the approach of this thesis: the identification of the factors which affect methane yield through thermal pre-treatment, and selection of optimal operating conditions that play a key role on the process economics in order to consolidate thermal pre-treatment process as a costeffective technology for anaerobic digestion of waste activated sludge improvement.

\subsection{Main objectives}

In order to overcome the above mentioned limitations, the main objective of the present thesis was the optimization of the thermal pre-treatment key operating factors for process efficiency improvement in terms of methane production during anaerobic digestion of waste activated sludge. Looking for new niches for global digestion enhancement the additional objective was the evaluation of novel thermal pre-treatment configurations on the anaerobic digestion of waste activated sludge efficiency in terms of methane production.

More specifically, the objectives were:

Optimization of thermal pre-treatment operating conditions

1. Analysis of viability of considering the severity factor and sludge solubilisation as prediction parameters for pre-treatment process efficiency.

2. Assessment of the influence of key thermal pre-treatment parameters on sludge solubilisation and methane production for waste activated sludge.

3. Determination of the optimum conditions for thermal pre-treatment of waste activated sludge in terms of methane production improvement. 
4. Assessment of the effect of exceeding thermal pre-treatment temperature on anaerobic digestion enhancement.

Evaluation of alternative schemes combining thermal hydrolysis and anaerobic digestion

5. Study of the different approach of thermal hydrolysis and anaerobic digestion: separate digestion of liquid and solid fractions of thermally pre-treated secondary sludge.

6. Evaluation of an alternative pre-treatment approach - "gas explosion" on the anaerobic digestion efficiency in terms of methane production.

\subsection{Thesis outline}

In order to fulfill the objectives stated above, the development of the thesis was as below described.

A general review on digestion of sludge, pre-treatment technologies and thermal hydrolysis is presented in Chapter 2, where the current situation was discussed and compared in order to revise the main issues related to the thesis. Next, in Chapter 3, the experimental methodology was summarized, describing the equipment for hydrolysis and digestion, and the monitoring tools. The key operating and performance parameters were also described, and a special section was dedicated to the experimental design and statistical analysis as the main tool for screening and optimization. Subsequently, the influence of different temperature-time-flash combinations was assessed in terms of sludge solubilisation and anaerobic biodegradability of thermally pre-treated waste activated sludge (Chapter 4). Through statistically guided Box-Behnken experimental design and Response Surface Method, the optimum conditions for thermal hydrolysis of waste activated sludge were determined and are presented in Chapter 5. The effect of exceeding thermal pre-treatment temperature was evaluated in terms of thermal pre-treatment behaviour and efficiency (Chapter 6). Analysis of physical (sludge solubilisation) and biological (sludge biodegradation) behaviour obtained applying different severity conditions was performed and is demonstrated in Chapters 5\&6. Looking for new approach methods, the study of the novel application of thermal hydrolysis and anaerobic digestion integration - separate digestion of liquid and solid fractions of thermally pretreated secondary sludge was accomplished (Chapter 7). To the same, innovative method of the pretreatment process was performed and is submitted in Chapter 8 where "gas explosion" pre-treatment (simple pressure effect performed with $\mathrm{CO}_{2}$ and $\mathrm{CH}_{4}$ ) was applied for sludge solubilisation and anaerobic digestion improvement. After all, the general discussion of the results obtained in the 
present thesis together with the specific conclusions was summarized in Chapter 9. In the last thesis part, Chapter 10, the future perspectives were proposed and described in order to fill out the existing niches for thermal pre-treatment and anaerobic digestion process enrichment. 
CHAPTER 2

Introduction 



\subsection{Wastewater and sludge treatment: global situation}

As the quality of life and people's awareness has improved, an increasingly significant responsibility has emerged - to protect the environment. Therefore, to enhance the quality of the water ecosystem, the number of waste water treatment plants (WWTP) has rapidly increased, following the increasingly restrictive regulations. Sewage treatment generally includes three main levels: primary, secondary (biological) and tertiary (or advanced) treatments.

Primary treatment is designed to remove gross, suspended and floating solids from raw sewage. It includes screening to trap solid objects and sedimentation by gravity to remove suspended solids. Secondary (biological) treatment removes the dissolved organic matter that escapes primary treatment. This is achieved by microbes consuming the organic matter as food, and converting it to carbon dioxide, water, and energy for their own growth and reproduction. The biological process is then followed by additional settling tanks (secondary sedimentation), to remove most of the suspended solids. Tertiary treatment is simply an additional treatment beyond secondary. Tertiary treatment can remove more than $99 \%$ of all the impurities from sewage, producing an effluent of almost drinking-water quality. The related technology can be very expensive, requiring a high level of technical know-how and well trained treatment plant operators, a steady energy supply, and chemicals and specific equipment which may not be readily available (World Bank Group, 2016).

Biological waste water treatment process is commonly used as a core process in a majority (approx. 90\%) of municipal WWTP, producing huge amounts of solid waste - sludge (Kuglarz et al. 2013). It is estimated that in WWTPs located in the European Union, about 11.5 million tons of dry matter is generated annually (European Commission, 2010). The most commonly used sludge disposal methods are incineration, landfill and land application (Salsabil et al. 2010). However, the overall situation is not so straightforward and has several negative aspects.

The enforcement of the European legislation regarding Urban Wastewater Treatments Directive (91/271/EEC) leads to a non-negligible increase in sludge production. At the same time, disposal routes are subjected to more social and legal constraints (Bougrier et al. 2008). Incineration is quite expensive because it needs the treatment of flue gas in order to remove toxic compounds and ash has to be treated like a hazardous waste; it is thus highly debated. The main disposal route, land application or agricultural use (42\% in 2010), has uncertainties about its potential risk on human health and the environment due to a variety of potentially harmful substances, such as organic contaminants, heavy metals and pathogens (Bougrier et al. 2007; European Commission, 2010).

Furthermore, it is assumed that the annual quantity of sludge produced in Europe will increase in the future (13.0 million tons in 2020) due to the increasing population, the greater number of sewage 
treatment facilities and the high quality standards required for sewage purification (Carballa et el. 2009; European Commission, 2010). After all, sludge handling is one of the most difficult and expensive items for a WWTP, since it accounts for $30-40 \%$ of capital costs and $50 \%$ of operating costs of the plant (Wilson and Novak, 2009; Ruffino et al. 2015). So, this increasing sludge production causes a large problem to communities and wastewater treatment plant operators, forcing them to look for and apply more efficient treatment in order to reduce sludge quantity in the WWTP.

The most commonly sludge treatment methods used nowadays are: composting, aerobic digestion and anaerobic digestion (AD) (Hanjie, 2010; Pilli et al. 2015).

Composting is an aerobic bacterial decomposition process to stabilise organic wastes and produce humus (compost). Compost contains nutrients and organic carbon which are excellent soil conditioners. Composting takes place naturally on a forest floor where organic materials are converted to more stable organic materials (humus) and the nutrients are released and made available for plant uptake. However, drawbacks of composting by-products are cost for site preparation and equipment, the lengthy treatment period, targeting final use of compost product, and environmental issues such as odors and dust if not managed properly. Some investment in equipment and site preparation is required or recommended. Composting is not a rapid stabilization process and, depending upon technique, could take several weeks to achieve stable compost. Moreover, the process control is often insufficient to achieve high-quality compost that meets the disinfection criteria (Brown et al. 1998). Aerobic digestion is a biological treatment process that uses long-term aeration to stabilize and reduce the total mass of organic waste by biologically destroying volatile solids. The process uses natural microbial colonies and molecular oxygen to decompose organic substances in the wastewater. The microbes feed on undesired biological substances in the water, creating aggregates or "flocks" of organic substances and microorganisms that settle to the bottom of the container. Nevertheless, there are a number of drawbacks. Aerobic digestion does not produce energy; contrariwise, the process is energy intensive. Temperature variability throughout the year causes variability in the operating performance and stabilized sludge may be difficult to dewater (Hill, 2012).

Anaerobic digestion (AD) of sludge is considered the main sludge treatment option that can fit into the frameworks of new regulations, reducing the overall amount of sludge to be disposed (about $30-40 \%)$ and generating energy rich biogas (60 - 70\% methane) that can be valorised energetically (Appels et al. 2010). Moreover, it has very limited adverse environmental impact thanks to few emissions and low energy consumption (Khalid et al. 2011; Mata-Alvarez et al. 2011).

This priority process is further described and analyzed in a following section 2.2 . 


\subsection{Anaerobic digestion: key issues with sludge}

\subsubsection{Microbiology and biochemistry}

Anaerobic digestion is a multi-step biological process that converts organic material into biogas and digestate by microbial action in the absence of oxygen through four main steps (Figure 1): (I) hydrolysis step degrades both insoluble organic material and high molecular weight compounds such as lipids, polysaccharides, proteins and nucleic acids into soluble organic substances (e.g. amino acids, fatty acids and sugar); (II) acidogenesis or fermentation of the hydrolysed products to volatile fatty acids (VFA) along with ammonia $\left(\mathrm{NH}_{3}\right)$, carbon dioxide $\left(\mathrm{CO}_{2}\right)$, hydrogen sulphide $\left(\mathrm{H}_{2} \mathrm{~S}\right)$ and other by-products; (III) acetogenesis, where the higher organic acids and alcohols produced by acidogenesis are further digested by acetogens to produce mainly acetic acid as well as $\mathrm{CO}_{2}$ and hydrogen $\left(\mathrm{H}_{2}\right)$; and the final (IV) methanogenesis processes, the conversion of acetic acid, carbon dioxide and hydrogen into methane and carbon dioxide.

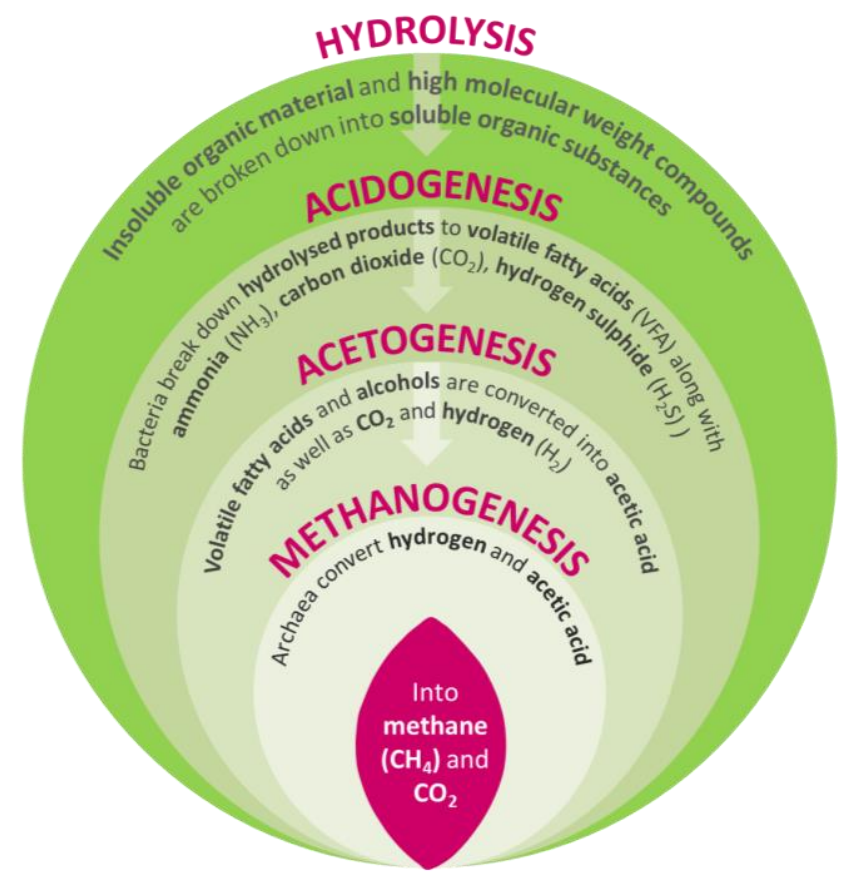

Figure 1. Stages of anaerobic digestion.

These steps are interdependent and the performance of each affects the next. For maximum anaerobic digestion process efficiency, i.e., hydrolysis, acidogenesis, acetogenesis and methanogenesis, there must be a balance in the rate of conversion from one step to the next (Vivalin et al. 2004; Appels et al. 2008; Shana et al. 2013).

The $\mathrm{AD}$ is normally carried out as one-stage process at mesophilic $\left(30-40^{\circ} \mathrm{C}\right)$ or thermophilic $\left(50-55^{\circ} \mathrm{C}\right)$ temperatures. In general, mesophilic anaerobic digestion of sewage sludge is more widely used compared to thermophilic digestion, mainly because of the lower energy requirements 
and higher stability of the process (Gavala et al. 2003; Climent et al. 2007). It is important to maintain a stable operating temperature in the digester, since sharp and/or frequent fluctuations in temperature affect the bacteria, especially methanogens. Process failure can occur at temperature changes in excess of $1{ }^{\circ} \mathrm{C} /$ day (Appels et al. 2008).

\subsubsection{Anaerobic digestion of waste activated sludge}

In waste water treatment plants, anaerobic digestion is generally applied to the mixture of primary and secondary (waste activated - WAS) sludge (Table 1) (Metcalf and Eddy Inc. et al. 2003, Turovskiy and Mathai 2006, Fabregat et al. 2011, Suárez-Iglesias et al. 2017). It is worth mentioning that from the point of view of anaerobic degradation, these two types of sludge are quite different.

Primary sludge is the result of the capture of suspended solids and organics in the primary treatment process through gravitational sedimentation, typically by a primary clarifier. It is composed by water ( $>90 \%$ by weight) and easily biodegradable solids (because of its higher amounts of carbohydrates and fats) and results in a volatile solids removal of $50-60 \%$ and high biogas yields (Oosterhuis et al. 2014).

Table 1. General characteristics of primary and secondary sludge.

\begin{tabular}{lll}
\hline Parameter & Primary sludge & Secondary sludge \\
\hline Total solids (\%TS) & $2.0-8.0$ & $0.8-3.3$ \\
Organic solids (\%TS) & $60-80$ & $59-88$ \\
Grease and fats (\%TS) & $6-35$ & $2-12$ \\
Carbohydrates (\%TS) & app. 34 & app. 20 \\
Protein (\%TS) & app. 16 & app. 34 \\
Lipids (\%TS) & app. 17 & n.a. \\
Nitrogen (N, \%TS) & $1.5-4$ & $2.5-4$ \\
Phosphorus (P, \%TS) & $0.17-0.6$ & $0.6-2.3$ \\
Organic acids (mg/L as acetic acid) & $200-2000$ & $1100-1700$ \\
pH & $5-8$ & $6.5-8$ \\
Biodegradability $\left(\% \mathrm{COD}_{\mathrm{T}}\right)$ & $55-60$ & $27-55$ \\
\hline $\mathrm{a}_{\mathrm{n} . \mathrm{a} . \text { not available. }}$ & &
\end{tabular}

The biological sludge obtained in the secondary treatment process is composed by water ( $>95 \%$ by weight) and a mixture of microbial cells and extracellular polymeric substances (EPS), which are a complex mixture of biopolymers comprising polysaccharides, proteins, nucleic acids, uronic acids, humic substances, and lipids, amongst others. EPS are three-dimensional, gel-like and relatively recalcitrant by nature thus reducing its availability to anaerobic micro-organisms (Jung et al. 2015). Furthermore, microbial cells, cell walls and membranes in the WAS are strong barriers that do not easily permit the penetration of hydrolytic enzymes making a hydrolysis rate-limiting step during the 
anaerobic digestion (Romero et al. 2013; Cho et al. 2014). Therefore secondary sludge has a slow degradation process resulting in high retention times ( $>20$ days), large quantities of biosolids produced because of low biodegradability with volatile solids removal rates of $32-50 \%$ and restricted methanogenic production (Strong et al. 2011; Abelleira-Pereira et al. 2015).

In spite of their different nature, primary and secondary sludge are digested together. Moreover, due to the high water content in sludge, which is difficult to remove, traditional digesters commonly require a huge operating volume. Consequently, application of AD is difficult in small WWTPs and in highly urbanized areas where space is limited (Duan et al. 2012; Liao et al. 2016). Furthermore, pathogens, present is sewage, are frequently transferred to sludge during treatment processes, where their concentration can be even higher, as compared to raw (non-digested) sludge. It is commonly known that $\mathrm{AD}$ process conducted in mesophilic conditions usually does not ensure complete removal of pathogens. Thereby, both, raw and digested sludge are considered as potential source of pathogens (Kuglarz et al. 2013).

The pressure of more stringent regulations on sludge treatment and disposal routes, and the complex biodegradability of waste activated sludge have forced wastewater treatment plants to reevaluate their sludge management strategies. The achievement of faster degradation rates, reduction of final amounts of biosolids to be disposed, sludge sanitation, improvement of dewaterability and enhancement of biogas production are nowadays the main goals for WWTP operators developing novel process for sludge treatment.

A graphical scheme of global situation faced by waste water treatment plants and sludge treatment is below enclosed. 


\section{Global situation of WWTP and sludge treatment}

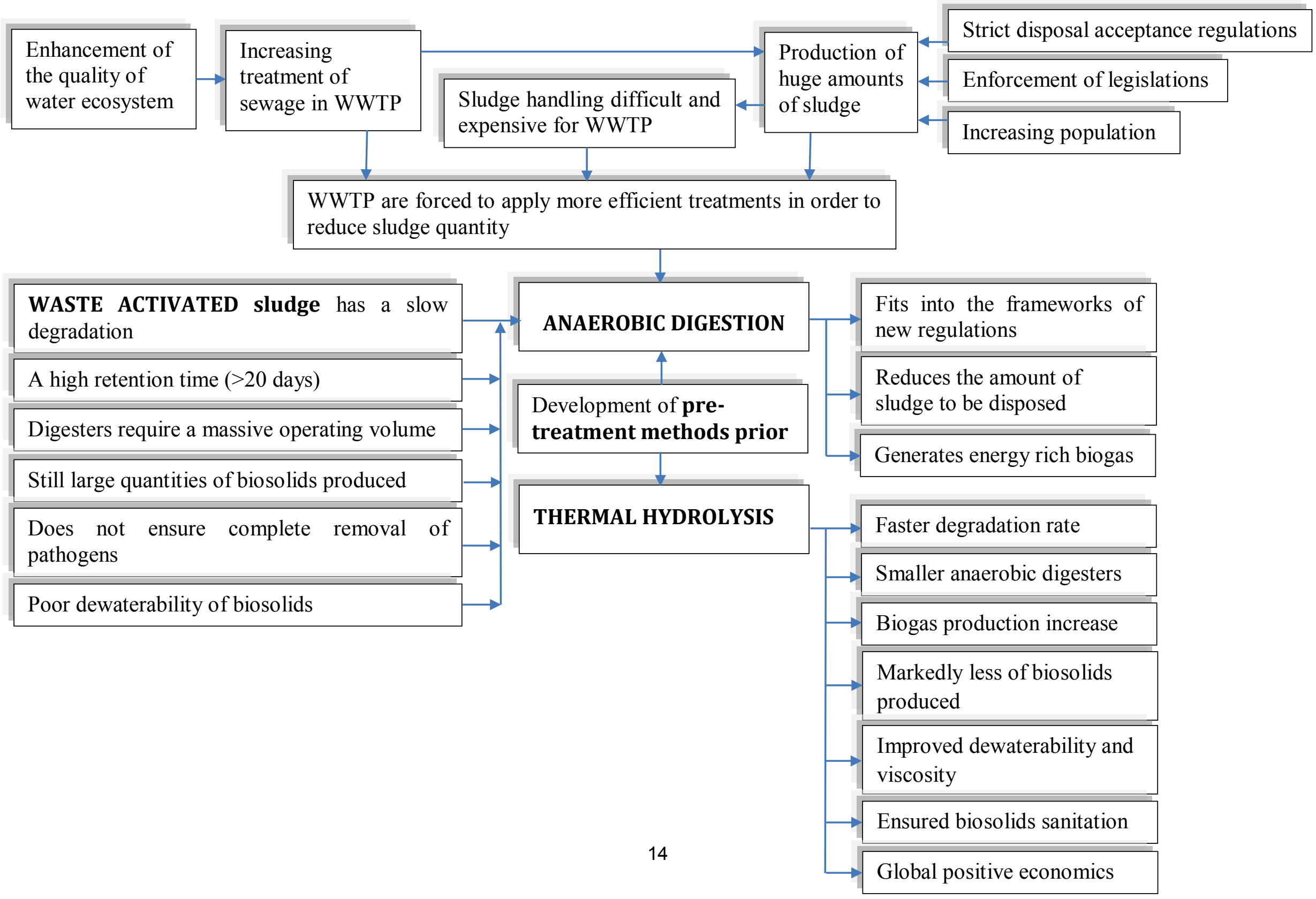




\subsection{Sludge pre-treatment processes: a review}

A number of pre-treatment methods prior to $\mathrm{AD}$ have been developed and investigated in order to improve and enhance the disintegration and solubilisation of sludge solids. They all induce the solubilisation of complex particulate matter (a transfer from the particles to the liquid fraction), so it is more rapidly and completely consumed during anaerobic digestion, increasing the volume of biogas produced, and decreasing the amount of solids to be disposed (Pérez-Elvira et al. 2010). Pretreatment methods that have been shown to have a positive effect include physical, chemical and biological techniques, or a combination of them.

Next sections (2.3.1-2.3.3) describe all the existing sludge pre-treatment processes, indicating the main positive and negative aspects of each, and a final global comparison is summarized in section 2.3.4.

\subsubsection{Physical pre-treatments}

High pressure homogenizers: These pre-treatment units consist of a multistep high-pressurepump and a homogenising valve (Figure 2). The pump compresses the sludge to pressures up to several hundred bar. When passing through the homogenising valve, the pressure drops below the vapour pressure of the fluid, and the velocity increases up to $300 \mathrm{~m} / \mathrm{h}$. Formed cavitation bubbles implode, inducing the fluid temperature of several hundred degrees Celsius, which disrupts the cell membranes. This process has been tested at full-scale for anaerobic digestion. A fraction of digested sludge was treated at 150 bar and re-introduced in the digester, which led to an increase of biogas production by $30 \%$ and a reduction of sludge volume by $23 \%$ (Onyeche, 2007).

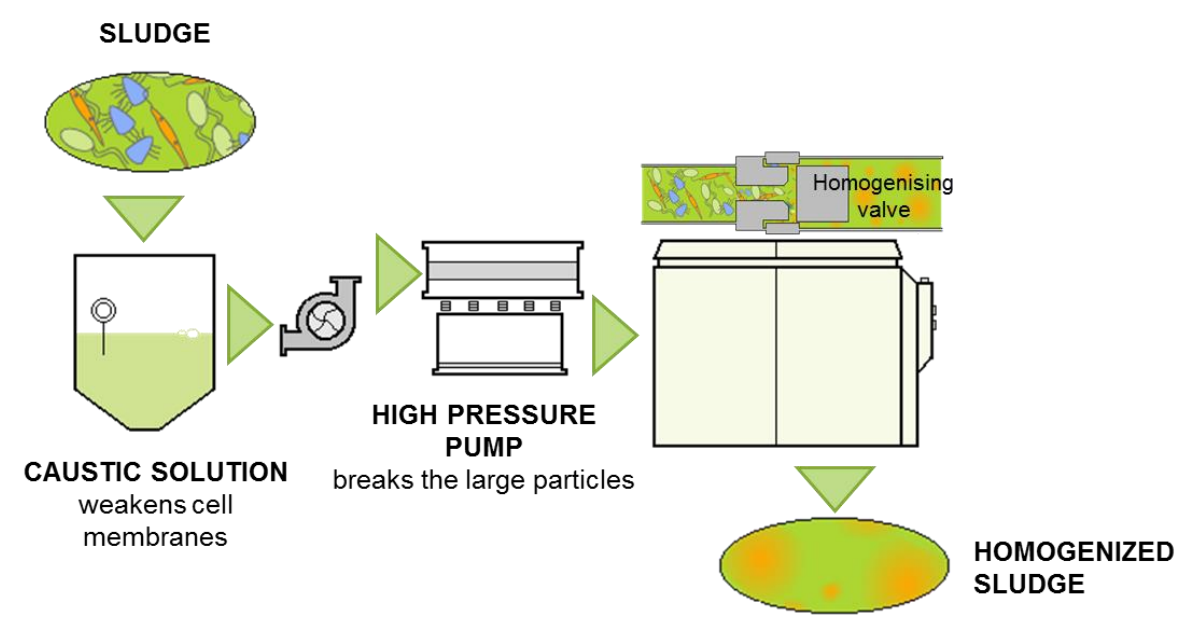

Figure 2. High pressure homogenizer. 
Several other processes which are based on sludge pressurisation and depressurisation are commercially available. Examples are:

* The Crown ${ }^{\circledR}$ process (Biogest, Germany), operating at 12 bar in several full-scale implementations (Biogest).

* Cellruptor or Rapid non-equilibrium decompression (RnD®) process (Ecosolids, UK). Sludge is compressed at pressures higher than 1 bar. A gas, which is soluble in the sludge stream, is introduced in the sludge stream. The gas, due to its rapid rate of diffusion across the cell walls, is transported across the cell walls. The gasified sludge stream is then depressurised. This rapid, non-equilibrium decompression causes exceedingly high shear rates and irreversible cell rupture, decreasing particle size, and releasing the interstitial water to the sludge stream. Biogas production can be increased from $0.3-0.6 \mathrm{~m}^{3} / \mathrm{kgVS}$ to $0.5-0.8 \mathrm{~m}^{3} / \mathrm{kgVS}$ (Giachino, 2011).

* Microsludge ${ }^{\circledR}$ process (Paradigm Environmental Technologie Inc, USA). Sludge is first treated with chemicals with the aim of adjusting the $\mathrm{pH}$ to 11 or 2 in order to weaken cell walls. A high pressure homogeniser at 830 bar then provides cellular disruption. This process was applied in Los Angeles WWTP. Treated waste activated sludge was introduced in a digester together with primary sludge, with a ratio 68/32 (w/w). The degradation of mixed sludge was increased from $50 \%$ to $57 \%$ (Stephenson et al. 2007).

Positive $(\checkmark)$ and negative $(\boldsymbol{x})$ aspects of high pressure homogenizers are:

$\checkmark$ Compact equipment;

$\checkmark$ Better dewaterability of the final sludge;

$\boldsymbol{x}$ Low reduction of pathogens;

× Clogging problems caused by coarse and fibrous particles;

x High maintenance cost;

$\boldsymbol{x}$ High tensions and erosion in the pump and homogenising valve;

× High operating cost.

Ultrasonic pre-treatment: The ultrasonic disintegration unit (Figure 3) consists of an ultrasound generator operating at frequencies of $20-40 \mathrm{kHz}$ to transmit mechanical impulses to the bulk liquid through a sonotrode. Pressure waves lead to cavitation bubbles forming in the liquid phase, which grow and then implode releasing localised high energy (local heating and high pressure), which cause sludge disintegration and, at high energy, the rupture of microbial cells. 


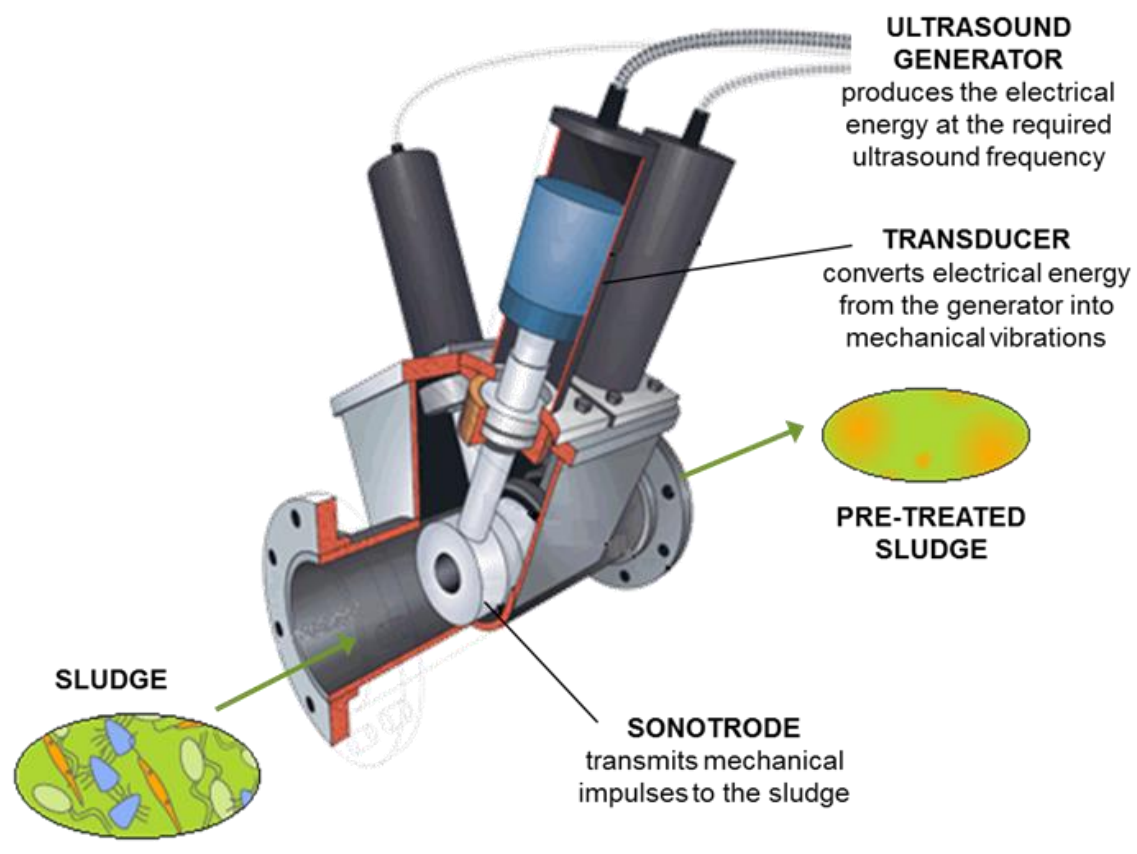

Figure 3. Ultrasonic pre-treatment unit.

The application of ultrasonication for sludge treatment was studied by various researchers in laboratory and full scale systems. Ultrasonic pre-treatment enhances the rate of hydrolysis by disrupting the cells, which leads to elution of intracellular organic substances. Laurent et al. (2009) observed a significant increase of $22.4 \%$ in COD solubilisation, $39.9 \%$ in TSS solubilisation and $48.8 \%$ in VSS solubilisation at specific energy input of $163,300 \mathrm{~kJ} / \mathrm{kg} \mathrm{TS}$, respectively. Several studies showed that sludge solubilisation is proportional to supplied energy. Higher input of specific energy will lead to higher sludge solubilisation. Xu et al. (2010) reported that on increasing the ultrasound energy density from $0.12 \mathrm{~W} / \mathrm{mL}$ to $1.5 \mathrm{~W} / \mathrm{mL}$, the SCOD varied from $10.78 \%$ to $15.11 \%$ at $30 \mathrm{~min}$ and from $15.96 \%$ to $20.76 \%$ at $60 \mathrm{~min}$, respectively. Both biogas generation and solids reduction were improved and SRT was decreased notably during the anaerobic digestion of ultrasonicated sludge. Erden et al. (2010) observed 36\% VS reduction in the digester fed with sonicated sludge $(9,690 \mathrm{~kJ} / \mathrm{kg}$ TSS $)$ at the end of the operation. Ultrasonication also proved to be an efficient method to reduce the pathogens. Jean et al. (2000) reported that the heterotrophic bacteria had been reduced by $82 \%$ at a high ultrasonic intensity level $(0.33 \mathrm{~W} / \mathrm{mL})$ for 40 min reaction time. A $93 \%$ reduction was observed for total coliforms within 10 min of treatment and the survival ratio of total coliforms bacteria was less than $1 \%$ at 40 min of ultrasonication.

Ultrasounds have been implemented extensively in industry, mainly as pre-treatment for anaerobic digestion. For example, the implementation in Bamberg's WWTP (280,000 PE, Germany) has been described by Neis et al. (2008). Xie et al. (2007) estimated the energy ratio 
between net energy generation and electricity consumption by an ultrasound device. In this full scale experiment carried out in Singapore, the methane production increased by $45 \%$, with an energy ratio of 2.5 (assuming an electricity yield of $2.2-3 \mathrm{kWhm} \mathrm{CH}$ ). There are some commercial devices, such as Sonix (Sonico, UK), Biosonator (Ultrawaves, Germany), Smart DMS (Weber Ultrasonics, Germany) and Sonolyzer (Ovivo, USA).

Positive $(\checkmark)$ and negative $(\boldsymbol{x})$ aspects of ultrasonic homogenizers are:

$\checkmark$ Reliability of operation (high degree of research and development);

$\checkmark$ No clogging problems;

$\checkmark$ Simple management and compactness;

$x$ Erosion in the sonotrode;

x High maintenance cost;

x Negative energy balance due to the high energy consumption of the equipment.

Grinding-Stirred ball mills: This technology consists of a cylindrical grinding chamber almost completely filled with grinding beads (Figure 4). An agitator forces the beads into a rotational movement. The micro-organisms are disintegrated in between the beads by shear- and pressureforces.
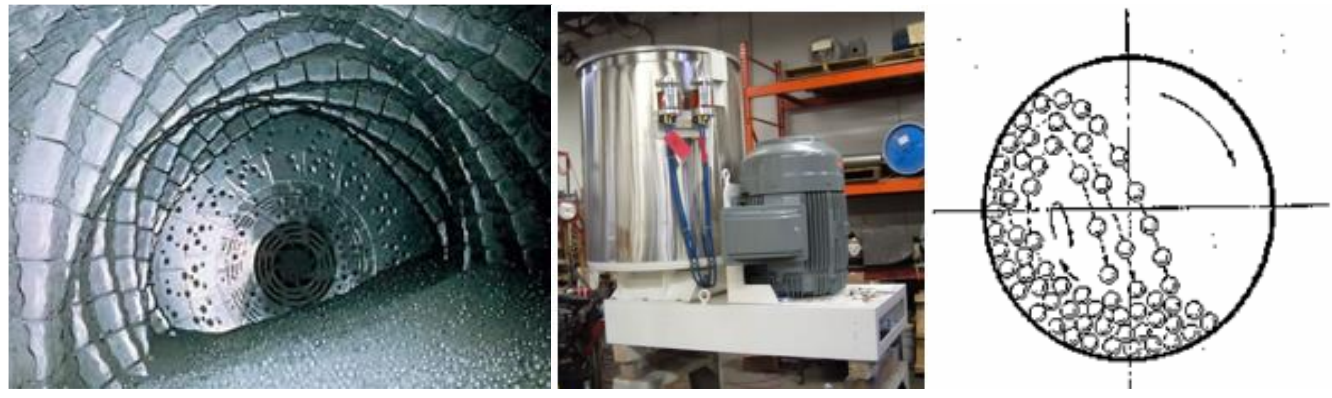

Figure 4. Grinding-Stirred ball mills.

Main research has been done by Kunz and Wagner (1994), Baier and Schmidheiny (1997), Winter (2002) and Müller et al. (2004). Although batch laboratory studies showed potential volatile solids destruction and enhanced biogas production, at full scale the results were poor. The technology was developed by Kady International, USA (Bio-Lysis ${ }^{\circledR}$ Sludge reduction process), consisting of high-speed "rotary mills" that shear the activated sludge. The Bio-Lysis did not have an effect on the sludge yield in a full-scale demonstration at the Plum Island WWTP near Charleston, S.C. 
Positive $(\checkmark)$ and negative $(\boldsymbol{x})$ aspects of stirred ball mills are:

Equipment robustness;

$\times$ Huge erosion in the grinding chamber;

× High energy friction losses;

× Clogging problems;

$\times$ The degree of disintegration of the sludge is lower compared to other techniques.

Lysis centrifuge: The centrifugal forces created in the lysate-thickening centrifuge (Figure 5) are deliberately applied to cell destruction. This disruption takes place using a special beater (ring) which is integrated into the centrifugal thickener and which dissipates the kinetic energy provided by the centrifuge. Cell destruction takes place in the centrifuge effluent following thickening. Lysis-centrifuge operates directly on the thickened sludge stream in a dewatering centrifuge (Dohanyos et al. 1997). After this, it is then re-suspended with the liquid stream.

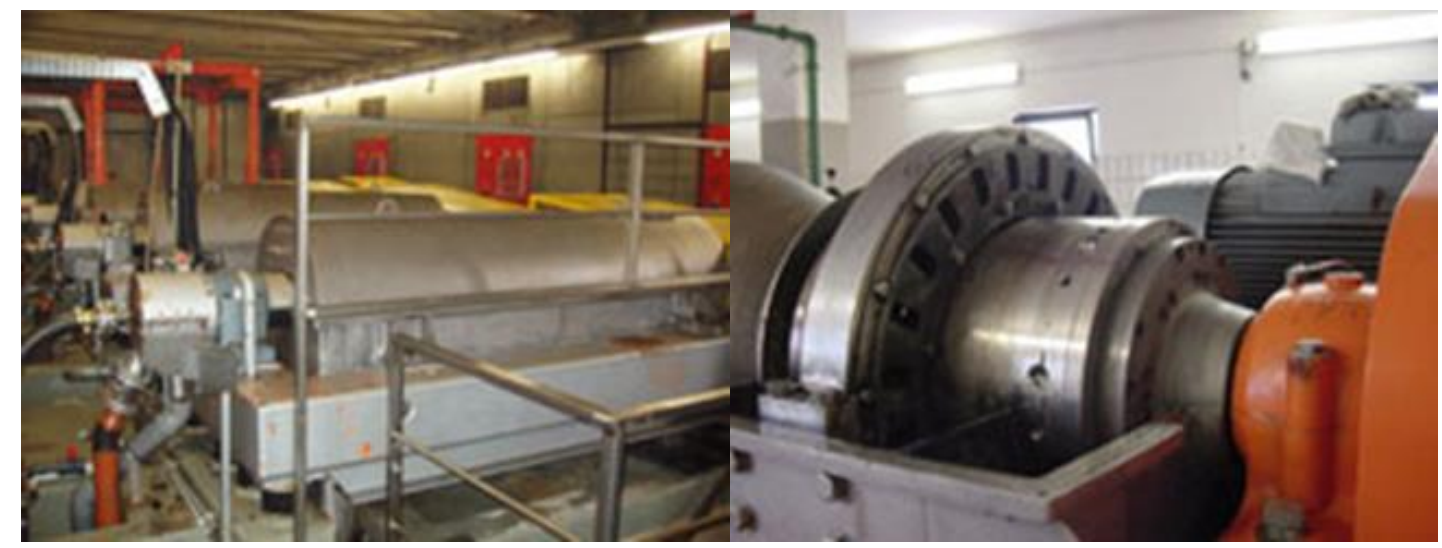

Figure 5. Lysate-thickening centrifuge.

It has been implemented in several wastewater treatment plants as a pre-treatment for anaerobic digestion: Liberec (100,000 PE, Czech Republic), Furstenfeldbruck (70,000 PE) and AachenSoers (650,000 PE) in Germany (Zabranska et al. 2006). The increase of biogas production is 15 $-26 \%$.

Positive $(\checkmark)$ and negative $(\boldsymbol{x})$ aspects of the Lysat centrifuge are:

$\checkmark$ Moderate energetic consumption;

$\times$ Low degree of sludge disintegration;

x High operating and maintenance cost;

$\times$ Wear on the equipment plates. 
Focused-pulse technology: This technology consists of an electro-hydraulic method. The idea is to treat the sludge by a high voltage electric field $(20-30 \mathrm{kV})$ in very rapid pulse periods. The shockwaves created in the sludge induce sudden disruption of cellular membranes, and polymeric structures (Figure 6) (Weise and Jung 1998; Weise and Jung 2001; Müller, 2001).

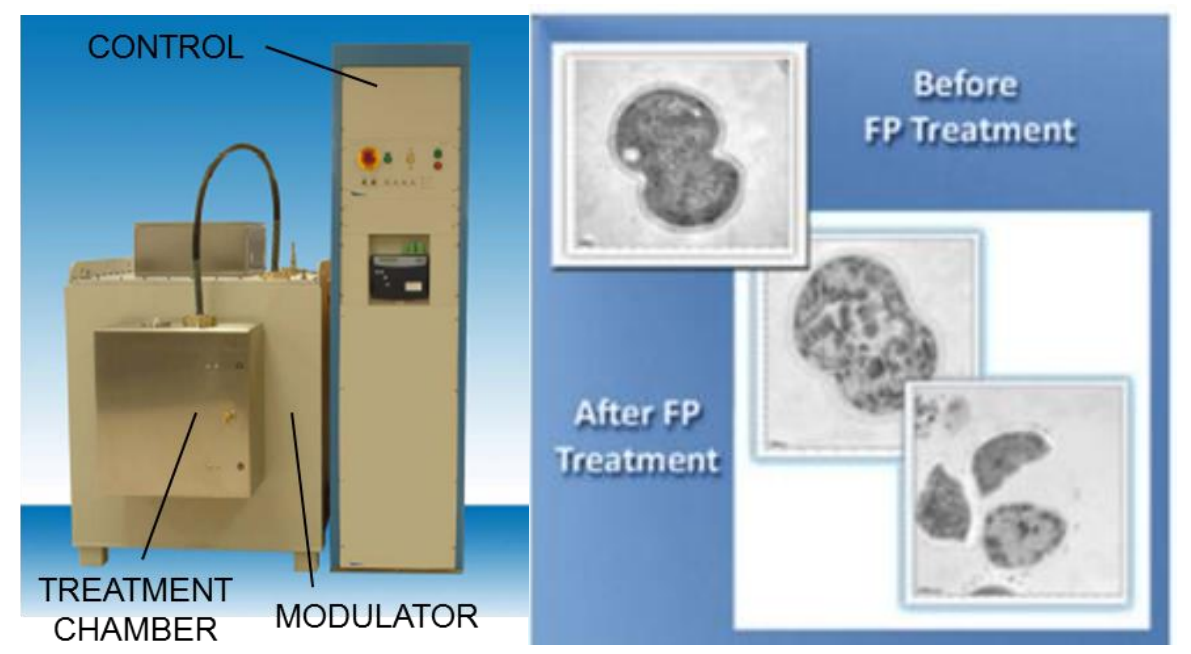

Figure 6. Focused-pulse pre-treatment unit.

Commercial technologies are OpenCel® (Trojan Technologies, USA) and BioCrack® (Vogelsang, German). Both combine mechanical maceration with an electrokinetic process. According to the commercializing companies, the cyclic exposure to positive and negative charges weakens the cell wall, and eventually the cyclic forces cause cell rupture and release of internal contents.

Positive $(\checkmark)$ and negative $(\boldsymbol{x})$ aspects of the high performance pulse technique are:
$\checkmark$ Compact equipment;
$\times$ Erosion in the electrodes;
$\times$ Low research and development;
$\times$ Contradictory results.

Thermal pre-treatment: Thermal hydrolysis (TH) process is the most widespread high pressure steam pre-treatment process used in Europe where sludge is heated in a hydrolysis reactor with live steam from a steam boiler to about $170^{\circ} \mathrm{C}$ and 8 bars pressure for about $30 \mathrm{~min}$ (Figure 7). Heat applied during thermal pre-treatment disrupts the chemical bonds of the cell wall and membrane, thus solubilising the cell components. 


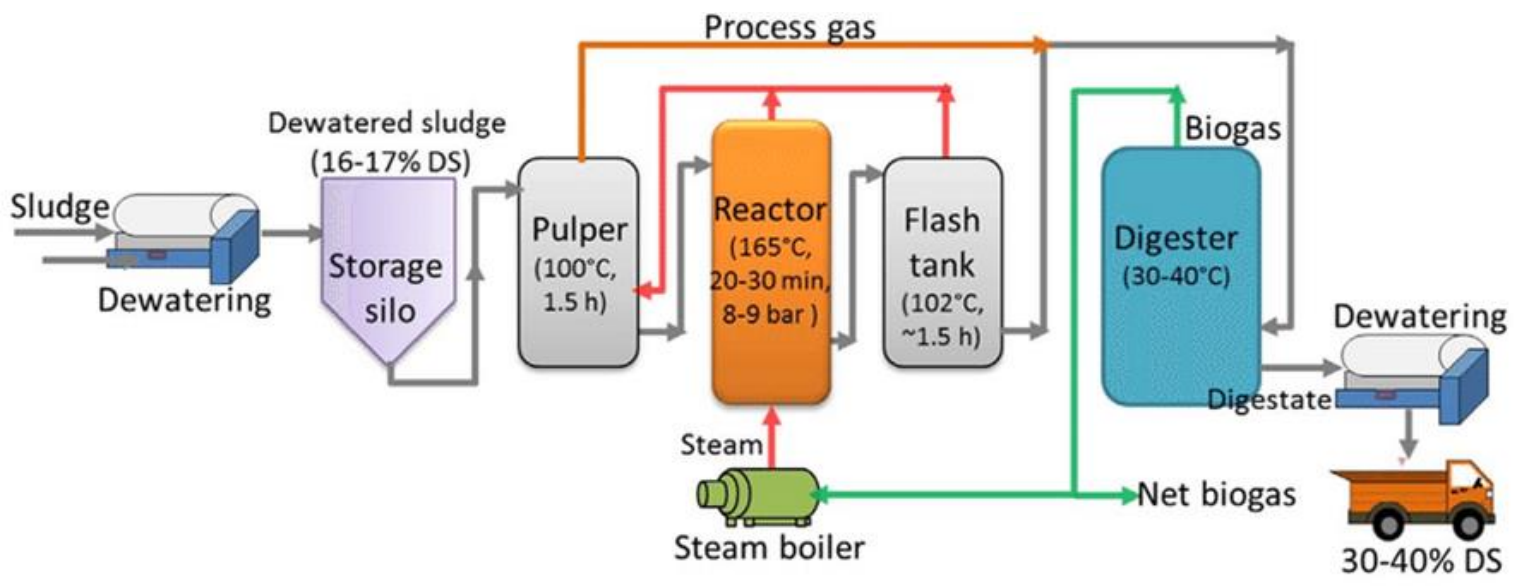

Figure 7. Schematic of thermal pre-treatment process.

Thermal hydrolysis and related heat treatment processes have long been used in sludge treatment, although for different purposes. Traditionally, sludge from wastewater treatment processes were simply dewatered and disposed immediately. Thermal hydrolysis was originally used for conditioning the sludge and improving its dewaterability. Early research on $\mathrm{TH}$ processes began as early as the 1970's aimed at improving the settleability and filterability of sludge by altering the sludge's physical characteristics. Thermal hydrolysis was found to destroy the structural integrity of microbes in the sludge and cause the lysis of cell walls, which released cell contents. Higher temperatures and treatment times were found to destroy more cell walls and insoluble proteins could also be broken down into more soluble amino acids. Later, it was realized that combining thermal pre-treatment with anaerobic digestion could potentially improve biogas production and remove odour. Early tests on both the laboratory and pilot-scale showed good results. Anaerobic digestion has today become a promising method for sludge treatment and $\mathrm{TH}$ is an important pre-treatment method to improve the efficiency of the process, especially for the digestion of WAS. Essentially, under high temperature conditions (130 $200^{\circ} \mathrm{C}$ ), a hydrolysis reaction occurs to break down complex molecules in sludge into simpler compounds. This results in the improved bioavailability of sludge contents for $\mathrm{AD}$ ( $\mathrm{Li}$ and Noike, 1992; Strong et al., 2011). Additional advantages of thermal treatments include sludge sanitation, reduction of sludge viscosity with subsequent enhancement of sludge handling, and no extra energy needs, since energy requirements can be covered by excess biogas production and energy balance is positive (Kepp et al. 2000). Disadvantages are largely increased soluble inert fraction and final effluent colour (Dwyer et al. 2008), increased ammonia inhibition in the main digester due to increased performance (Batstone et al. 2010), and possibly, poorer centrifuge or press solids capture due to an increase in fines. 
Current commercial thermal pre-treatment processes are discussed in a section 2.4.7 Commercial thermal pre-treatment processes.

Positive $(\checkmark)$ and negative $(\mathbf{x})$ aspects of thermal hydrolysis are:

$\checkmark$ Most effective treatment according to energetic considerations;

$\checkmark$ Significantly improves the biodegradability of sludge;

$\checkmark$ Allows significantly higher loading rates resulting in smaller digestion plants;

$\checkmark$ Increases rate of biogas production;

$\checkmark$ Very good dewaterability of the final sludge;

$\checkmark$ Sludge viscosity reduction; better digester mixing;

$\checkmark$ Removal of digester foaming;

$\checkmark$ Best sludge disinfection (Class A); reduces odour;

$\checkmark$ Significantly reduces downstream requirements for drying and other thermal processes;

$\checkmark$ Numerous sites successfully operating at full-scale;

$x$ Fouling of the heat exchangers (when existing);

× Pumps maintenance (if existing);

× Higher ammonia concentration than standard digestion;

$\times$ Requires boilers;

× Sludge need cooling prior to AD;

× Requires centrifuge thickening to $16-18 \%$ DS

\subsubsection{Chemical pre-treatments}

Oxidation: The most widely used chemical pre-treatment method is ozonation. Ozonation leads to partial sludge solubilisation and methane yield increases with ozone dose. A too high ozone dose will result in reduced apparent solubilisation due to oxidation of the solubilised components (Yeom et al. 2002). In addition, it is oxidative, and may therefore increase destruction at the expense of methane yield. Several studies have shown an optimal ozone dose for the enhancement of anaerobic biodegradability: $0.1 \mathrm{gO}_{3} / \mathrm{gCOD}$ (Weemaes et al. 2000), 0.2 $\mathrm{gO}_{3} /$ gTSS (Yeom et al. 2002), $0.15 \mathrm{gO}_{3} / \mathrm{gTS}$ (Bougrier et al. 2007).

Ozonation has been combined with anaerobic digestion as a pre-treatment (Weemaes et al. 2000, Yeom et al. 2002, Bougrier et al. 2007) or post-treatment and recycling back to the anaerobic digester (Goel et al. 2003, Battimelli et al. 2003). Goel et al. (2003) showed better performance and lower ozone consumption in the case of post-treatment and recycling in the digester. 
Hydrogen peroxide has also been used as an oxidant (Valo et al. 2004, Rivero et al. 2006). The COD removal during anaerobic digestion was enhanced by means of oxidation at $90^{\circ} \mathrm{C}$ with 2 $\mathrm{gH}_{2} \mathrm{O}_{2} / \mathrm{kgVSS}$, but not by the oxidation at $37^{\circ} \mathrm{C}$ (Rivero et al. 2006).

However, the process consisting of one anaerobic digester, high temperature oxidation and a second digester led to the highest removal of faecal coliforms (Rivero et al. 2006). Use of Fenton catalysed oxidation (0.067 g Fe(II)/gH $\mathrm{gH}_{2}$ and $60 \mathrm{gH}_{2} \mathrm{O}_{2} / \mathrm{kgTS}$ ) decreased sludge resistance to dewatering in terms of capillary suction time (CST), but did not have a positive effect on sludge dewatering performance on a belt press simulation (Kaynak et al. 2008).

Positive $(\checkmark)$ and negative $(\mathbf{x})$ aspects of ozone pre-treatment are:

$\checkmark$ Better dewaterability of the final sludge;

× High energy consumption;

x Metals present in the initial sludge $(\mathrm{Fe}, \mathrm{Zn}, \mathrm{Ag}, \mathrm{Cu})$ are transferred to the liquid phase, that should be purified.

Alkaline hydrolysis: During the alkaline pre-treatment, the $\mathrm{pH}$ of the sludge is increased up to 12, maintaining this value for a period of time (normally 24 hours). This process may be used to hydrolyse and decompose lipids, hydrocarbons and proteins into smaller soluble substances such as aliphatic acids, polysaccharides and amino acids (Chiu et al. 1997; Mukherjee and Levine 1992). Alkali treatment is relatively effective in sludge solubilisation, with in order of efficacy being $\left(\mathrm{NaOH}>\mathrm{KOH}>\mathrm{Mg}(\mathrm{OH})_{2}\right.$ and $\mathrm{Ca}(\mathrm{OH}) 2$ ) (Kim et al. 2003). However, too high concentrations of $\mathrm{Na}+$ or $\mathrm{K}+$ may cause subsequent inhibition of anaerobic digestion (Mouneimne et al. 2003). It is normally combined with thermal treatment. Sludge solubilisation and anaerobic biodegradability increase with alkali dose and temperature, with an upper limit (Kim et al. 2003, Valo et al. 2004). Compared to thermal hydrolysis, alkali treatment temperature is normally lower, and the increase in temperature normally driven by chemical processes (from 170 to $120-130^{\circ} \mathrm{C}$ ). Alkali treatment $(\mathrm{pH} 12, \mathrm{NaOH})$ combined with microwave irradiation $\left(160^{\circ} \mathrm{C}\right)$ led to methane production $10 \%$ higher than microwave irradiation alone (Dogan et al. 2009). However, since the addition of alkali increases mineral content of digested sludge, it reduces the interest of co-treatment on sludge reduction (Valo et al. 2004). In addition, sludge dewaterability may be diminished by KOH addition (Everret, 1974). Dogan and Sanin (2009) observed an improvement on the dewaterability (measured by CST) by 
about $22 \%$ after anaerobic digestion of pre-treated sludge $\left(\mathrm{pH} 12,160^{\circ} \mathrm{C}\right.$ microwave) compared to anaerobic digestion of waste activated sludge.

Positive $(\checkmark)$ and negative $(\mathbf{x})$ aspects of acid or alkaline hydrolysis are:

$\checkmark$ Low energetic requirements;

$\checkmark$ Very good dewaterability of the final sludge;

$\times$ Modification of the sludge composition;

x Possible damage to the bacteria responsible for the microbiologic activities;

$\times$ Bad odour generation;

$x$ Corrosion and fouling of the equipment;

× Higher COD in the final effluent due to the presence of non-biodegradable substances.

\subsubsection{Biological pre-treatments}

Bacterial and enzyme hydrolysis: The biological-enzymatic pre-treatments include the possibility of applying commercial enzymes, which can be selected based of the type of enzyme and quantity required (Davidsson et al. 2007). It is also possible to use an enzyme-producing microorganism that releases hydrolytic enzymes during the hydrolysis step (Hasegawa et al. 2000). Finally, it is possible to use the inherent enzymatic activity of the secondary sludge, called autohydrolysis. This option is the most interesting one from a practical point of view.

The autohydrolysis pre-treatment is a biological-enzymatic pre-treatment, which involves subjecting the secondary sludge to a temperature of $55^{\circ} \mathrm{C}$ and a limited amount of oxygen in batch operation. These conditions allow the microorganisms in the secondary sludge to release the hydrolytic enzymes contained in their own metabolic system, which ultimately leads to the hydrolyzation of the secondary sludge (Carvajal et al., 2013). The autohydrolysis pre-treatment uses synergic effects produced by the temperature applied and the hydrolytic enzymes released, thus obtaining a pre-treatment with a simple operation process and low requirement of an external energy source. As a consequence, the product expected is a solubilized and hydrolysed organic matter, with improved anaerobic degradation, but without associated high costs.

The hydrolytic enzymes of the activated sludge may be located in the soluble phase or in the sludge floc (Burgess et al. 2008). Some researchers have observed that when secondary sludge is subjected to environmental change, such as an increase in temperature or a decrease in oxygen concentration, the production of hydrolytic enzymes is promoted (Yan et al. 2008). A high solubilisation of organic matter and an improvement in dewaterability and pathogen have been reported (Mayhew et al. 2002). 
The full scale development of this technology corresponds to the GE Monsal's Biological Hydrolysis process (GE Water \& Process technologies, USA). GE Monsal's Biological Hydrolysis process (advanced digestion) separates the hydrolysis phase of anaerobic digestion from the methanogenesis (biomethanation) phase and creates an ideal environment to maximize the efficiency of each phase.

Positive $(\checkmark)$ and negative $(\boldsymbol{x})$ aspects of biological pre-treatment are:

$\checkmark$ Low energy consumption;

$\checkmark$ No stress on the equipment;

× High operating cost if commercial enzymes are used;

× The enzymatic mechanisms are still not clear;

× Autohydrolysis: more research needed;

$x \quad$ The usage of enzymes to better the sludge stability is not clear;

x High generation of odours.

\subsubsection{Discussion about pre-treatment processes}

The different sludge pre-treatment methods have improved recently in popularity due to a number of factors, including: (i) increased energy production and positive balance in WWTPs, (ii) increased final handling costs (especially for dewaterability and transport) and (iii) increased legislative requirements for sludge stabilisation performance and pathogen removal.

Table 2 summarizes the development level of the different sludge pre-treatment processes, indicating if it is laboratory (LAB) or full-scaled (FULL), and the corresponding name of the process. The activity regarding research and development $(R \& D)$ is also presented, indicating those processes that are nowadays subject of mayor interest.

Table 2. General comparison of existing processes to reduce sludge impact (LAB: only proven at laboratory scale; FULL: full-scaled).

\begin{tabular}{|c|c|c|c|}
\hline Process & Technology & Development & R\&D activity \\
\hline High pressure homogenizers & $\begin{array}{l}\text { Crown } \AA, \text { Cellruptor } \AA \text {, } \\
\text { Microsludge } \AA\end{array}$ & FULL & YES \\
\hline Ultrasonic pre-treatment & $\begin{array}{l}\text { Sonix }{ }^{\circledR}, \text { Biosonator }{ }^{\circledR} \text {, } \\
\text { Sonolyzer }{ }^{\circledR} \text {, Smart DMS }\end{array}$ & FULL & YES \\
\hline Grinding-stirred ball mills & Bio-Lysis ${ }^{\circledR}$ & FULL & YES \\
\hline The lysis centrifuge & - & FULL & $\mathrm{NO}$ \\
\hline
\end{tabular}




\begin{tabular}{llll}
\hline Focused-pulse technology & OpenCEL ${ }^{\circledR}$, BioCrack ${ }^{\circledR}$ & FULL & YES \\
\hline Thermal hydrolysis & Cambi ${ }^{\circledR}$, Biothelys ${ }^{\circledR}$, & & \\
& $\begin{array}{l}\text { Exelys }{ }^{\circledR}, \text { Lysotherm }{ }^{\circledR}, \\
\text { Haarslev CHS, Turbotec }{ }^{\circledR}, \\
\text { Aqualysis }{ }^{\circledR}, \mathrm{tH}_{4}^{+}, \mathrm{TPH}\end{array}$ & FULL & YES \\
\hline Alkaline hydrolysis & - & LAB & NO \\
\hline Oxidation & - & LAB & NO \\
\hline $\begin{array}{l}\text { Bacterial and enzyme } \\
\text { hydrolysis }\end{array}$ & Monsal & FULL & YES \\
\hline
\end{tabular}

Although knowledge and experience is being gained when operating full-scale installations, and despite that there is still limited knowledge concerning routine operation of some of the technologies, a general analysis can be done based on the current state-of-the-art.

Table 3 presents some features regarding applicability of different sludge pre-treatment processes.

Table 3. Main features of the sludge pre-treatment processes.

\begin{tabular}{|c|c|c|c|c|c|}
\hline & $\begin{array}{c}\text { Increased } \\
\text { biogas }\end{array}$ & $\begin{array}{l}\text { Dewaterability } \\
\text { improvement }\end{array}$ & $\begin{array}{c}\text { Biosolids } \\
\text { hygienization }\end{array}$ & $\begin{array}{l}\text { Maintenance } \\
\text { requirements }\end{array}$ & $\begin{array}{l}\text { Operating } \\
\text { costs }\end{array}$ \\
\hline High pressure homogenizers & ++ & + & - & -- & -- \\
\hline Ultrasonic pre-treatment & ++ & - & + & -- & + \\
\hline Grinding-stirred ball mills & - & - & - & -- & -- \\
\hline The lysis centrifuge & + & - & - & - & - \\
\hline Focused-pulse technology & - & - & - & -- & -- \\
\hline Thermal hydrolysis & ++ & ++ & ++ & $+/++$ & ++ \\
\hline Alkaline hydrolysis & + & - & - & - & - \\
\hline Oxidation & + & - & - & - & - \\
\hline $\begin{array}{l}\text { Bacterial and enzyme } \\
\text { hydrolysis }\end{array}$ & + & + & + & + & + \\
\hline
\end{tabular}

Although lab and full-scale studies generally indicate the increase in biogas production, the best results correspond to high pressure homogenizers, ultrasonic pre-treatment and thermal hydrolysis. Worse results are presented for technologies such as grinding and focused-pulse.

When analysing the characteristics of the biosolids, concerning dewaterability and hygienization, thermal hydrolysis appears as the only technology that guarantees good results in both items. Ultrasonic pre-treatment normally worsens the sludge dewaterability, while high pressure 
homogenization does not assure sanitization. Bacterial and enzymatic hydrolysis also presents good performance in both aspects.

Finally, no energy assessments neither maintenance nor operating considerations are usually discussed in scientific reports. Table 3 also presents a comparison of these items, based on reported full-scale experience.

From a practical approach of the maintenance requirements, all the technologies, except thermal and enzymatic pre-treatments, demand continuous replacement of parts (in general technologically expensive for those mechanic technologies) or reagents consumption (for chemical treatment). Regarding operating costs (energy), Cano et al. (2016) presented an energy feasibility study of the main sludge pre-treatment technologies. By making a simple evaluation of the energy consumption by the pre-treatments, they stated that unfortunately not all the pre-treatment technologies have an energy self-sufficiency to be implemented in a WWTP, thus requiring a continuous energy investment. Generally, pre-treatments consuming electricity do not satisfy its energy demands from the biogas production in the same process, although high solubilization or biogas production increases are reached. Just ultrasonic pre-treatment applied in full-scale plants, with commercial technologies such as Sonix or Biosonator, provide an energetically self-sufficient pre-treatment. In the case of thermal pre-treatment, the potential to be implemented with full energy integration is much higher, since this pre-treatment can recover heat from the biogas engine as well as electrical energy in the same extent as for electric pre-treatments. This way, full energy integration can be achieved in thermal hydrolysis plants. Several theoretical approaches and simulations also state that thermal pre-treatment presents a high potential to be fully integrated in WWTP with a complete energy recovery and self-sufficiency, being sludge concentration the main key factor to assure this important feature.

\subsection{Thermal pre-treatment: state of the art}

\subsubsection{Overall vision}

Thermal pre-treatment or thermal hydrolysis (TH) is basically a process whereby biosolids are pressure-cooked in a reactor at high temperature and pressure to improve the digestibility of the biosolids, usually before anaerobic digestion. In some technologies a sudden drop in pressure, resulting in so-called "steam explosion" is included, although none of the bibliographic information analyses whether the steam explosion or even re-flashing (repetition of sudden decompression without extra heat consumption) of sludge can enhance further the solubilisation of organic matter. Direct sewage sludge pre-treatment preceding sludge anaerobic digestion, may be either on primary, to waste activated sludge or to the mix of primary and waste activated sludge. However, since 
primary sludge is already readily degradable, pre-treatment may be less effective. Waste activated sludge, for the reasons described above, has relatively low degradability. Thus, waste activated sludge pre-treatment is often used in preference to primary sludge pre-treatment. Pre-treatment of mixed sludge may be useful when the sludge sanitation is needful.

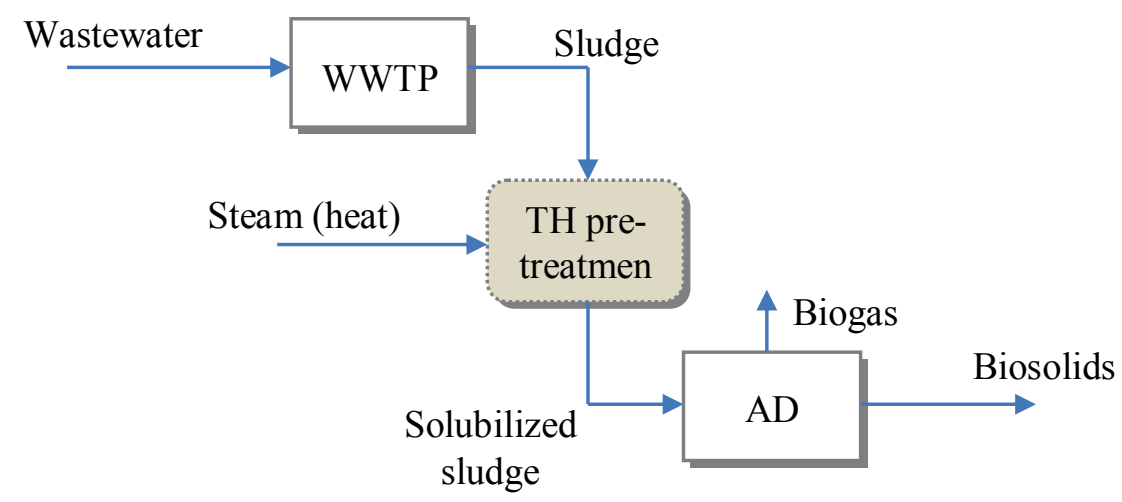

Figure 8. Schematic of a conventional thermal hydrolysis.

A substantial number of studies over the years has documented that thermal pre-treatment of waste activated sludge prior to anaerobic digestion can significantly improve the methane yield in biogas of WAS (Nielsen et al. 2011; Pilli et al. 2015). Therefore, thermal hydrolysis has a high level of acceptance in the scientific and industrial fields, with an increasing number of full scale units in WWTPs all over the world (Morgan-Sagastume et al. 2011). The mechanism of thermal pretreatment consists of chemical effect - reduction of particulate organic matter into lower molecular weight and simpler structure compounds that can be more easily and effectively assimilated by the active biomass, and physical effect - cell lysis (including the cell wall and the cell membrane) thus releasing organic compounds from the cell. In theory, this transformation is performed firstly by cell lysis and secondly by reducing the size of organic matter molecules (Prorot et al. 2011; Serrano et al. 2015).

During the pre-treatment under high temperature and steam pressure, the bacterial flock structure is disintegrated, the cells are opened and the cell content is released to the surroundings and made more accessible to the anaerobic microorganisms (Nielsen et al. 2011). This fact improves the overall digestion process velocity and the degree of sludge degradation thus reducing anaerobic digester retention time and increasing methane production rates (Climent et al. 2007). Final quantity of residual sludge and time of digestion can thus be reduced and biogas production can be increased (Bougrier et al. 2007). The types of molecules that are solubilised during thermal hydrolysis play a significant role in the enhancement of the subsequent anaerobic digestion. A successful anaerobic 
digestion process requires an efficient degradation of complex particulate substrate to methane gas, and various compounds may promote or inhibit some steps in this process. It is reasonable to surmise that such components could be set free during thermal treatment (e.g. heavy metals) or could be produced through the thermal pre-treatment of insoluble structures (e.g. volatile fatty acids from degradation of lipids) (Chowdhury et al. 2007; Appels et al. 2010). The majority of the sludge reduction studies indeed focused either on soluble chemical oxygen demand (SCOD) increase, sludge mass reduction, or floc size decrease. Hence, little information has been obtained about cell lysis or changes in the biological activity. The characterization of the impact of enhanced hydrolysis by the pre-treatment in terms of microbial activity (active cells able to convert organic matter) and viability (cell lysis with the resulting release of intracellular materials) is yet fundamental for sludge reduction optimization (Prorot et al. 2011). But still, thermal hydrolysis allows a high level solubilisation, an improvement in dewaterability and biogas production, modification in sludge characteristics (increase in filterability and viscosity reduction) (Bougrier et al. 2007; Salsabil et al. 2010). In addition, thermal pre-treatment has the benefit of sterilization and sanitation by killing most of the pathogens and bacteria in the feedstock (Hu and Chen, 2007). Therefore, the sludge after enhanced hygienization of thermal process can not only comply with the European Union (EU) policy on the elimination of pathogens, but also reach class A biosolid standard of the US Environmental Protection Agency (EPA), making it more suitable for subsequent land application (Xue et al. 2015).

\subsubsection{Process operating parameters}

Thermal hydrolysis has been studied using a wide range of temperatures ranging from 60 to $270^{\circ} \mathrm{C}$, for $10-180 \mathrm{~min}$ (Bougrier et al. 2007; Appels et al. 2010). If we consider temperatures impact on biogas production, thermal pre-treatments can be classified into two groups: treatments at temperatures of 70 or $121^{\circ} \mathrm{C}$ which led to a $20-30 \%$ biogas production increase and treatments at $160-180^{\circ} \mathrm{C}$ which led to a $40-100 \%$ biogas production increase (Figure 9 ). The $160-180^{\circ} \mathrm{C}$ pretreatments are thus most efficient to enhance sludge anaerobic digestion. Most of the studies reported an optimal temperature in the range from 160 to $180^{\circ} \mathrm{C}$ and treatment times for 30 to $60 \mathrm{~min}$ ( $\mathrm{Li}$ and Noike 1992; Bougrier et al. 2007). However, treatment time is often shown to have little effect in this temperature range (Valo et al. 2004; Climent et al. 2007; Donoso-Bravo et al. 2011). There is a statement saying that the higher the temperature, the more efficient the treatment (Prorot et al. 2011). However, temperatures higher than $180^{\circ} \mathrm{C}$ (by other authors temperatures over $200^{\circ} \mathrm{C}$ ) lead to the production of recalcitrant soluble organics or toxic/inhibitory intermediates, hence reducing the biodegradability (Wilson and Novak, 2009; Appels et al. 2010; Nielsen et al. 2011). These coloured 
recalcitrant compounds, which are called melanoidins, are produced by polymerisation of low molecular weight intermediates, such as carbohydrates and amino compounds at elevated temperature (Maillard reaction) (Dwyer et al. 2008). Thus, for higher temperature, biodegradability of sludge is no more improved and decreased. Penaud et al. (2000) have founded that by removing these refractory dissolved organic compounds responsible for brown color from the thermally treated sludge, the biodegradability increase. This highlighted that melanoidins may be undegradable to biological treatment (Liu et al. 2012). But, a thermal hydrolysis around $175^{\circ} \mathrm{C}$, combained with anaerobic digestion, can highly reduce sludge production. This reduction can reach $50-70 \%$ according to the process (Bougrier et al. 2007). High temperatures treatments are usually applied to sludge by heat exchangers or by steam injection (Climent et al. 2007).

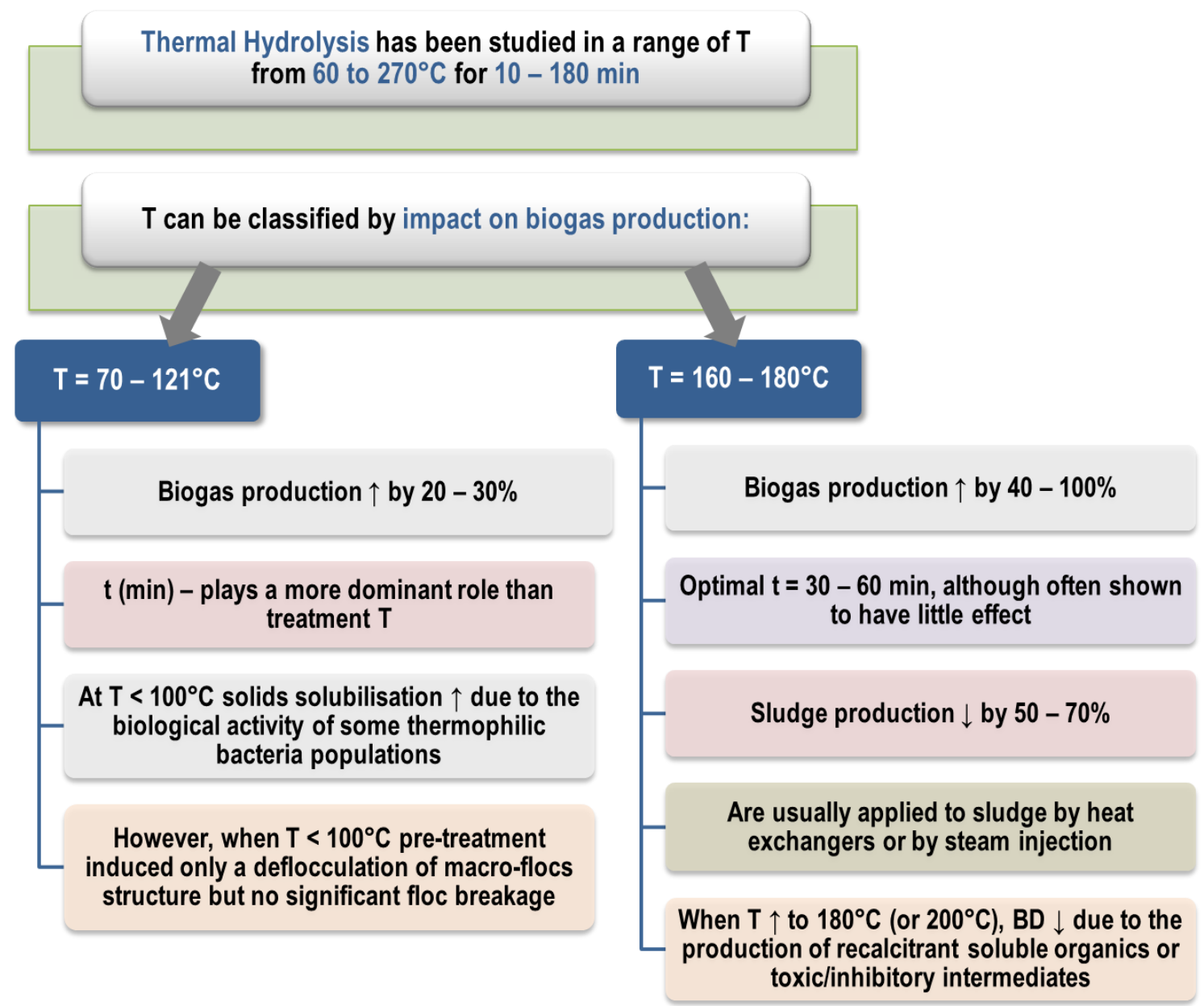

Figure 9. Thermal hydrolysis process operating parameters.

Application of low temperature thermal pre-treatment $\left(<100^{\circ} \mathrm{C}\right)$ can also solubilize organic substances in sludge solids (Ferrer et al. 2008). It has been pointed out as an effective treatment for increasing biogas production for both primary and secondary sludge (Climent et al. 2007). At low temperatures, treatment time plays a more dominant role than treatment temperature. Some authors have concluded that the solids solubilisation at temperatures around $70^{\circ} \mathrm{C}$ is enhanced 
because of the biological activity of some thermophilic bacteria populations with optimum activity temperatures in the high values of the thermophilic range (Appels et al. 2010). Prorot et al. (2011) hypothesized that, in the considered temperature range (from $50^{\circ} \mathrm{C}$ to $95^{\circ} \mathrm{C}$ ), heat treatment induced only partial sludge destructuration. Results from organic matter solubilisation and cell lysis indicated that thermal treatment below $100^{\circ} \mathrm{C}$ generated a release of organic components from the particulate to the soluble fraction, including intracellular materials. However, the results from floc structure analysis showed that thermal treatment at temperatures below $100^{\circ} \mathrm{C}$ induced only a deflocculation of macro-flocs structure but no significant floc breakage. This lack of extracellular material solubilisation could explain that anaerobic intrinsic biodegradability of heat treated sludge did not increase even if the specific digestion rate was enhanced. So, it was supposed that improvement of activated sludge biodegradability require both intracellular material release (cell lysis) and complete floc disintegration (exopolymeric substances breakage). Ruffino et al. (2015) reported that specific methane production increased by $21 \%$ and $31 \%$ for WAS samples treated for $3 \mathrm{~h}$ at 70 and $90^{\circ} \mathrm{C}$, respectively. Thermal pre-treatments also decreased waste activated sludge viscosity.

\subsubsection{Energetic considerations}

The most significant drawback of this treatment (especially at high temperature/pressure) is the high requirement of energy for steam production that can have a negative impact on the total energy balance of sludge treatment. Some authors have pointed out that the energetic expense can be balanced due to the increment in sludge biodegradability and, to the same, biogas production, and to the use of sludge residual heat in the maintenance of digester temperature, thus resulting in an energetically neutral or even self-sufficient process (Climent et al. 2007; Appels et al. 2010). Haug et al. (1978) performed energy balances for thermal pre-treatment and an anaerobic digestion system to treat WAS and mixed primary/secondary sludge. In case of WAS, a $70 \%$ increase in gas production rate was expected and required in this system to obtain a net energy production when an anaerobic digestion followed thermal pre-treatment. A thorough energy balance study was also carried out by Pérez-Elvira et al. (2012), which considered different configurations of the thermal pre-treatment and anaerobic digestion system as well as different options for energy integration. Without implementing an energy integration scheme, it was found that the feed concentration of sludge must be increased (from 3\% to $7 \%$ total solids) in order to produce enough biogas in the system for the process to become energetically self-sufficient. An energy integration scheme which considered heat recovery from the flash vapor outlet of the reactor can lower the required feed concentration. It was also found out that only thermal hydrolysis of WAS is beneficial rather than the 
mixture of primary sludge and WAS to be pre-treated using thermal pre-treatment. This scheme can help a 30\% increase in biogas production to achieve net energy production. Oosterhuis et al. (2014) reported when a mixture of $40 \%$ of primary and $60 \%$ of waste activated sludge is digested, the amount of heat that will be generated by the co-generation of heat and electricity will be sufficient to produce steam for thermal pre-treatment of waste activated sludge alone. Pilli et al. (2015) from the mass-energy balance study reported that the least quantity of digestate produced to dewater, transport and land application was generated by thermal pre-treated secondary sludge at $30.0 \mathrm{~g} \mathrm{TS} / \mathrm{L}$. To the same, thermal pre-treatment was energetically beneficial at $30.0 \mathrm{~g} \mathrm{TS} / \mathrm{L}$ for the secondary sludge compared to the primary and the mixed sludge at different solids concentrations $(20.0,30.0$ and 40.0 g TS/L). Furthermore, thermally pre-treated secondary sludge required lower retention time (10 days) to have a positive energy balance (i.e. energy output was greater than energy input).

\subsubsection{Influence of thermal pre-treatment on sludge solubilisation and biogas production}

Thermal hydrolysis is a favorable pre-treatment technology with a long-term development. In the 70's researches have already found out that excess sludge treated by thermal pre-treatment showed better digestion capabilities in the subsequent reactions of the anaerobic digestion process with a higher removal efficiency of organics and more methane gas production (Zhang et al. 2014). The effect of thermal pre-treatment on the anaerobic biodegradability and toxicity of activated (secondary) sludge was investigated in the study of Stuckey and McCarty (1984). The temperature range studied was between $150^{\circ} \mathrm{C}$ and $275^{\circ} \mathrm{C}$. They observed an optimum in methane production after pre-treatment at $175^{\circ} \mathrm{C}$ whereas at more elevated temperatures, a decline in methane production and sludge biodegradability was observed which was attributed to the formation of toxic, refractory compounds. Another experiment involving pre-treatment of primary and secondary sludge for $1 \mathrm{~h}$ at temperatures between $120^{\circ} \mathrm{C}$ and $220^{\circ} \mathrm{C}$ was described by Pinnekamp (1989). A decrease in gas production below that of the non pre-treated sludge was observed for temperatures higher than $180^{\circ} \mathrm{C}$; however, the differences in gas yield increase at pre-treatment temperatures between $120^{\circ} \mathrm{C}$ and $180^{\circ} \mathrm{C}$ were not considerable. Li and Noike (1992) focussed on the thermal pre-treatment of secondary sludge and they reported $170^{\circ} \mathrm{C}$ and $60 \mathrm{~min}$ as the most favourable pre-treatment temperature and duration regarding COD removal and gas production during mesophilic $\left(37^{\circ} \mathrm{C}\right)$ anaerobic digestion yielding an increase of approximately $100 \%$ compared to the non pre-treated sludge. Valo et al. (2004) reported increments in SCOD of around 25\% and 60\% after thermal treatment of secondary sludge at 130 and $170^{\circ} \mathrm{C}$, respectively. The author also evaluated the biogas production of thermally treated sludge in batch tests at mesophilic temperatures and observed increment of $21 \%$ and $45 \%$ in biogas production, respectively compared to untreated sludge. Pérez- 
Elvira et al. (2010) reported 40\% higher yield of biogas from the system of thermal pre-treatment and anaerobic digestion than from the conventional $\mathrm{AD}$, experimenting with mixed sludge. DonosoBravo et al. (2011) reported around 55\% higher yield of biogas from the system of TH and AD than from the conventional $\mathrm{AD}$, testing with waste activated sludge. Wilson et al. (2011) reported biogas production increase between $24 \%$ and $59 \%$ after thermal pre-treatment at temperatures $150-170{ }^{\circ} \mathrm{C}$ and 5-8 bar pressure when compared with conventional mesophilic anaerobic digestion. Abe et al. (2013) reported that biogas production by anaerobic digestion of sludge with thermal pre-treatment at $200^{\circ} \mathrm{C}$ decreased by $33 \%$ in comparison to the gas yield from the digestion of sludge with thermal pre-treatment at $170^{\circ} \mathrm{C}$, and even less than the control in which the fed sludge was not pre-treated.

In the study of Wang et al. (1997) the effectiveness of lower temperature pre-treatment (60 $\left.100^{\circ} \mathrm{C}\right)$ on mesophilic $\left(37^{\circ} \mathrm{C}\right)$ anaerobic digestion of activated sludge was investigated. It was concluded that thermal pre-treatment resulted in a significant increase $(30-52 \%)$ in methane yield; however, no significant differences were observed between pre-treatments at $60^{\circ} \mathrm{C}, 80^{\circ} \mathrm{C}$ and $100^{\circ} \mathrm{C}$. The rate of the methane generation was higher after the pre-treatment at $60^{\circ} \mathrm{C}$ compared with $80^{\circ} \mathrm{C}$ and $100^{\circ} \mathrm{C}$. Due to the improved sludge hydrolysis resulting from thermal pre-treatment, methane production increased by $11 \%$ after $48 \mathrm{~h}$ pre-treatment at $50^{\circ} \mathrm{C}$ (Nges and Liu, 2009), and by $30-$ $50 \%$ after $9 \mathrm{~h}$ thermal pre-treatment at $70^{\circ} \mathrm{C}$ (Ferrer at el. 2008; Climent et al. 2007) compared to methane yields achieved without thermal pre-treatment. For the maximal temperature $\left(95^{\circ} \mathrm{C}\right)$ applied, COD, proteins and sugars solubilisation degrees reached $12.4 \%, 18.6 \%$ and $7.4 \%$, respectively, showing clearly the transfer of organic matter from the particulate to the soluble fraction of the sludge. The results from cell lysis analysis showed that thermal treatment induces a progressive cell lysis when increasing temperature from 50 to $95^{\circ} \mathrm{C}$. However, the impact on floc structure seemed to be limited as floc destructuration was limited to the temperature elevation at $50^{\circ} \mathrm{C}$. Above $50^{\circ} \mathrm{C}$ floc size distribution remained almost constant (Prorot et al. 2011).

\subsubsection{Influence of thermal pre-treatment on sludge dewaterability and viscosity}

Rheology change due to the thermal hydrolysis is arguably the most important consequence of the technology on sludge treatment as it allows higher digester loading rates - due to increase ease of downstream transport - and aids in dewatering (Stickland 2015).

Due to the high content of water in waste activated sludge ( $>95 \%$ by weight) and its poor removal efficiency, thermal pre-treatment was first applied to sludge to improve dewaterability. Extracellular polymeric substances have been found to bind large volumes of water, making WAS especially difficult to dewater. The aqueous phase is generally described as free water and bound water. The bound water needs a higher energy to be removed and some cannot be removed at all. 
This bound water content is one of the main limiting factors in the water removal efficiency (Neyens et al. 2003). Therefore, sludge dewaterability was reported to be improved after a treatment at a temperature higher than $150^{\circ} \mathrm{C}$ due to the breakdown of the gel structure of the sludge and the release of intracellular bound water (Bougrier et al. 2008). The increment by $50-100 \%$ of WAS dewaterability was obtained by Neyens and Baeyens (2003) which resulting in significant solidliquid separation and mass reduction of digestate dewatered cake. Thermal pre-treatment have improved dewaterability of primary and secondary solids mixtures with increasing temperature between $130^{\circ} \mathrm{C}$ and $170^{\circ} \mathrm{C}$ in a linear fashion from approximately 27 to $32 \%$ DS (Higgins et al. 2015). Baudez et al. (2013) and Farno et al. (2014) reported that thermal pre-treatment could reduce the viscosity of sewage sludge. The proportionality of the increase of soluble COD with the decrease of the yield stress as well as increase of infinite viscosity was found in the study of Farno et al. (2014). Zhang et al. (2014) reported that under the thermal hydrolysis conditions $170^{\circ} \mathrm{C}$ and $30 \mathrm{~min}$ volatile solids and viscosity reduced by $69.65 \%$ and $92.8 \%$ respectively. Viscosity is a useful parameter for operating and monitoring of biological processes, and the reduction of viscosity means that the sludge is more fluid so that a higher solid concentration of $8-12 \%$ can be fed to the digester. Conventional anaerobic digestion commonly treats sludge with a total solids content of 2 $5 \%$, because the high viscosity of sludge at greater total solids hampers mixing and mass transfer (Jolis, 2008). Moreover, if the viscosity of sludge is decreased by thermal pre-treatment, the energy required for stirring is lessened and the mass transfer is improved (Liao et al. 2016).

\subsubsection{Influence of thermal pre-treatment on anaerobic digestion retention time}

As thermal hydrolysis allows an increase in sludge solubility due to the microbial cells and extracellular polymeric substances disintegration, improvement in sludge biodegradability is obtained. Moreover, due to the enhanced hydrolysis stage, it is possible to accelerate the rate of biogas production, such that the same amount of biogas can be produced in a shorter time. The work of Xue et al. (2015) shows this influence very clearly. In their thorough study which looked at reaction temperatures between 60 and $180^{\circ} \mathrm{C}$ and times between 15 and $180 \mathrm{~min}$, the value of accelerated biogas production was optimal at approximately 10 days. Observing data taken at a reaction temperature $140^{\circ} \mathrm{C}$, biogas production was approximately $70 \%$ higher with thermal hydrolysis than without at a reduced retention time of 10 days. When retention time was increased to 20 days, the difference dropped to $<25 \%$ additional biogas for the hydrolysed system, as the biogas production from the control sluggishly narrowed the gap. Interestingly, in the control, the biogas yield at 10 days was approximately two thirds of that at 20 days, whist the reactor with pre-treatment was producing almost $95 \%$ of the 20 day yield within 10 days. This finding is mirrored by Ngwenya 
et al. (2015) who showed statistically insignificant difference in biogas production with thermal hydrolysis between 10 and 18 days at the same loading rates at laboratory scale. Chertsey, in the UK, has been running at hydraulic retention time of approximately 12 days at full-scale with good performance (Pook et al. 2013) whilst Wilson et al. (2008) concluded that digestion performance at 15 days retention time with thermal hydrolysis was equivalent to that without at 20 days. Therefore it may be hypothesized that running digestion plants at approximately 10 rather than 20 days retention time may be preferable when coupled with thermal hydrolysis.

\subsubsection{Laboratory scale thermal pre-treatments: a review}

Whilst there is a great deal of useful information in the literature, closer observation reveals that is difficult to cross-reference findings on both laboratory- and full-scale.

At laboratory-scale there appears to be no standardized apparatus for thermal hydrolysis testing, neither a standard protocol for running a thermal hydrolysis unit at that scale. This leads to inconsistent or even contrary results, such as steam explosion being highly influential (AbelleiraPereira et al. 2015, Perrault et al. 2015) or insignificant (Ngwenya et al. 2015); the requirement for long reaction times (Li and Noike 1992) or not (Nayens and Baeyens 2003, Abelleira-Pereira et al. 2015, Donoso-Bravo et al. 2011), as examples (Barber 2016). Furthermore, the optimum treatment conditions and digestion improvement are largely depending on the composition and nature of the sludge, which can vary over time, and between different wastewater treatment plants (Gavala et al. 2003, Appels et al. 2010). Thus, the variation in the obtained results may occur between different batches of sludge. And most studies are carried out either at one temperature for different pretreatment times or over a narrow temperature range for a determined pre-treatment time, thus resulting in a the contrary conclusions. Exact conclusions on the most efficient treatment procedures are, therefore, not fully possible (Nielsen et al. 2011).

In spite of these issues, the literature provides valuable information on expected trends and potential performance expectations based on use of thermal hydrolysis. Table 4 presents the short review of laboratory scale thermal pre-treatment processes: pre- treatment unit, operating conditions, substrate, anaerobic digestion conditions and main results.

$>$ Thermal pre-treatment unit: for the low temperature thermal pre-treatment $\left(<100^{\circ} \mathrm{C}\right)$ water baths, pre-treatment reactor with temperature controlled water jackets, steel vessels equipped with a heating coil, microwave and thermal reactor are used in laboratories. For the high temperature thermal hydrolysis $\left(>100^{\circ} \mathrm{C}\right)$ autoclaves or Zipperclave reactor, teflon jars heated in an oven, stainless steel hydrolysis reactor with the oil bath and pilot plants are used. Researches 
normally do not detail the structure of the equipment thus in some cases the operating principle can be not very clear. The most used high temperature TH unit autoclave is essentially a steel vessel (pressure system) through which steam (or electric) or other gas is circulated to perform scientific experiments. Typically the chambers in autoclaves are cylindrical. The high-pressure makes them self-sealing (the words "auto" and "clave" mean automatic locking), though for safety reasons most are also sealed manually from outside (Woodford, 2009). Pilot TH plants consist of a steam generator, hydrolysis reactor, where sludge is heated with a live steam until the required operating pressure and temperature, and decompression tank, to where hydrolysed sludge flows after the pre-treatment process. The most experiments are controlled in temperature.

Operating types: depending on the objective of the study, the operating conditions vary in a wide range. In all experiments the sludge is "cooked" at a set temperature for a certain period of time. However, at a high temperature $\mathrm{TH}$ the pressure forms in the reactor. This operating pressure is the equilibrium pressure corresponding to saturated steam inside the reactor (Abelleira et al. 2012). Therefore in some laboratory experiments sudden drop in pressure, resulting in so-called "steam explosion" is included. Zhang et al. (2014) detailed that hydrolysed sludge was delivered into the decompression tank by high-pressure steam. Shana et al. (2012) indicated that hydrolysed sludge was flashed out into the flash tank. Donoso-Bravo et al. (2010) and Pérez-Elvira et al. (2010) also pointed in their studies that at the end of the reaction time the decompression valve was automatically opened and the hydrolysed sludge flowed to the flash tank. Although there is no bibliographic information about the effect of steam explosion on hydrolysed sludge, it is supposed that sudden drop in pressure tears cells and fibers apart, further improving the disintegration effect (Menco, 2012).

Operating conditions varied in a wide range. The lowest pre-treatment temperature used was $30^{\circ} \mathrm{C}$ and the highest $190^{\circ} \mathrm{C}$. To the same, the shortest reaction time applied was $15 \mathrm{~min}$ and the longest 72 hours. However, it is worthy to mention, that extremely long pre-treatment times, like 10, 24 and $74 \mathrm{~h}$, were used for low pre-treatment temperatures $\left(<100^{\circ} \mathrm{C}\right)$.

Substrate and AD: due to the complex biodegradability and, therefore, low AD efficiency the majority of the thermal pre-treatment studies are performed for the WAS. Since primary sludge is already readily degradable and thus the pre-treatment is less effective, however some studies are performed for comparison purposes. Pre-treatment of mixed sludge may be useful when the sludge sanitation after AD is needful. At laboratory scale anaerobic digestion is carried out either 
in batch or in continuous (or semi) stirred tank reactors. The most studies are performed at mesophilic conditions $\left(35 \pm 2^{\circ} \mathrm{C}\right)$ with the hydraulic retention time $20-30$ days.

Despite the extensive TH process type (experimental unit, substrate, operating parameters) amplitude, all the researches work for the same aim - to improve anaerobic digestion of WAS. In most of the studies the main results are related with the enhanced biogas (methane) production, increased sludge reduction, enhanced COD solubilisation and biodegradability, affirmative sludge sterilization and improved sludge viscosity and dewaterability. However, it is worthy to mention, that just a very small number of researches introduce the energy balance in their works. From this short review just two authors performed the energetic cost comparison. Bougrier et al. (2007) reported that when the organic flow is equal to $32 \mathrm{~kg} / \mathrm{h}$ and that methane production is equal to $314 \mathrm{~mL} \mathrm{CH}_{4} / \mathrm{g} \mathrm{VS}$ added, the system would thus produce around $10 \mathrm{~m}^{3} \mathrm{CH}_{4} / \mathrm{h}$. Burning this methane would permit to obtain a power of $100 \mathrm{~kW}$, which would be largely sufficient to heat sludge. This confirms that energy required to perform the process can be positively balanced by biogas production. Salsabil et al. (2010) in their study estimated that high thermal treatment $\left(90^{\circ} \mathrm{C}\right.$ and autoclave) led to interesting cost reduction: about $30 \%$ under aerobic conditions and about $25 \%$ under anaerobic conditions. Even low thermal treatment led to non-negligible cost reduction: respectively $11 \%$ and $8 \%$ under aerobic and anaerobic conditions. 
Table 4. Literature data on laboratory scale $\mathrm{TH}$ processes.

\begin{tabular}{|c|c|c|c|c|c|}
\hline $\begin{array}{c}\text { Thermal pre-treatment } \\
\text { unit }\end{array}$ & Conditions & Substrate & Anaerobic digestion & Results & References \\
\hline \multirow[t]{4}{*}{$\begin{array}{l}\text { Water bath; } \\
\text { autoclave reactor }\end{array}$} & $\begin{array}{l}70^{\circ} \mathrm{C} ; 9,24,48,72 \mathrm{~h} \\
110-134^{\circ} \mathrm{C} ; 20- \\
90 \mathrm{~min}\end{array}$ & WAS & $\begin{array}{l}\text { Batch tests, at } 55^{\circ} \mathrm{C} 32 \\
\text { days }\end{array}$ & $\begin{array}{l}\text { No differences in biogas production were observed } \\
\text { when high temperature thermal treatment was } \\
\text { compared with untreated sludge. A } 50 \% \text { increment in } \\
\text { biogas production was observed for } 70^{\circ} \mathrm{C} \text { thermally } \\
\text { treated sludge. }\end{array}$ & Climent et al. 2007 \\
\hline & $\begin{array}{l}121^{\circ} \mathrm{C} 15 \mathrm{~min} \\
40,60,90^{\circ} \mathrm{C} 60 \mathrm{~min}\end{array}$ & WAS & $\begin{array}{l}\text { Stirred tank reactors, at } \\
37^{\circ} \mathrm{C}\end{array}$ & $\begin{array}{l}\text { The contribution in sludge reduction ranged between } \\
12 \% \text { and } 20 \% \text { when the temperature varied from } 40^{\circ} \mathrm{C} \\
\text { to } 90^{\circ} \mathrm{C} \text {. High thermal treatment }\left(90^{\circ} \mathrm{C} \text { and autoclave }\right. \\
\left.121^{\circ} \mathrm{C}\right) \text { led to cost reduction about } 25 \% \text { and low } \\
\text { treatment } 8 \% \text {. }\end{array}$ & Salsabil et al. 2010 \\
\hline & $\begin{array}{l}50,65,80,95^{\circ} \mathrm{C} \\
20 \mathrm{~min}\end{array}$ & WAS & $\begin{array}{l}\text { Batch tests, at } 33^{\circ} \mathrm{C} 24 \\
\text { days }\end{array}$ & $\begin{array}{l}\text { Thermal treatment below } 100^{\circ} \mathrm{C} \text { generated a release } \\
\text { of organic components from the particulate to the } \\
\text { soluble fraction, including intracellular materials, but } \\
\text { was not sufficient to produce a total floc breakage, } \\
\text { and was therefore not sufficient to increase intrinsic } \\
\text { biodegradability of activated sludge. }\end{array}$ & Prorot et al. 2011 \\
\hline & $\begin{array}{l}80^{\circ} \mathrm{C} ; 10 \mathrm{~h} \\
130 \& 170^{\circ} \mathrm{C} ; 15 \mathrm{~min}\end{array}$ & WAS & $\begin{array}{l}\text { Batch tests, at } 37^{\circ} \mathrm{C} 40 \\
\text { days }\end{array}$ & $\begin{array}{l}\text { Pre-treatment at } 80^{\circ} \mathrm{C} \text { had no effect on methane yield. } \\
\text { Pre-treatment at } 130 \& 170^{\circ} \mathrm{C} \text { increased the methane } \\
\text { production within the first } 4 \text { days but the } \\
\text { improvement following } 40 \text { days of digestion was only } \\
13 \% \text { and } 9 \% \text {, respectively. }\end{array}$ & Nielsen et al. 2011 \\
\hline Zipperclave reactor & $\begin{array}{l}130^{\circ} \mathrm{C} \mathrm{pH} 10,170^{\circ} \mathrm{C} ; \\
15,30,60 \mathrm{~min}\end{array}$ & WAS & $\begin{array}{l}\text { Batch tests, at } 35^{\circ} \mathrm{C} 23 \\
\text { days; continuous reactor, } \\
\text { HRT } 20 \text { days }\end{array}$ & $\begin{array}{l}\text { Waste activated sludge biodegradability increased by } \\
21 \% \text { and } 45 \% \text { with sludge pre-treated at } 130^{\circ} \mathrm{C} \mathrm{pH} 10 \\
\text { and } 170^{\circ} \mathrm{C} \text {. In a continuous reactor pre-treatment at } \\
170^{\circ} \mathrm{C} \text { was more efficient than pre-treatment at } 130^{\circ} \mathrm{C} \\
\mathrm{pH} 10 \text { for WAS reduction. It led to } 71 \% \text { of COD } \\
\text { degradation and } 59 \% \text { of TS degradation, with an } \\
\text { improvement of } 45 \% \text { in biogas production. }\end{array}$ & Valo et al. 2004 \\
\hline
\end{tabular}


$135^{\circ} \mathrm{C} 30 \mathrm{~min}$; $190^{\circ} \mathrm{C} 15 \mathrm{~min}$

$90-210^{\circ} \mathrm{C} ; 30 \mathrm{~min}$

WAS

Batch tests, from 17 to

24 days
Results obtained with a treatment at $190^{\circ} \mathrm{C}$ were

better than those obtained with treatment at $135^{\circ} \mathrm{C}$.

Semicontinuous reactor, With a thermal pre-treatment at $190^{\circ} \mathrm{C}, \mathrm{COD}$ removal HRT 20 days

yield increased from $52 \%$ to $64 \%$, and methane

Bougrier et al. 2007 production by $25 \%$.

For temperatures lower than $200^{\circ} \mathrm{C} \mathrm{COD}$

solubilisation was found to increase linearly with treatment temperature. Thermal treatments up to $190^{\circ} \mathrm{C}$ allowed the biogas production to increase during BMP tests. Biogas volume enhancement was linked to sludge COD solubilisation.

Pre-treatment reactor with temperature controlled water jackets

$50-65^{\circ} \mathrm{C}$, HRT 2 days $35^{\circ} \mathrm{C}$, HRT 2 days

Primary sludge

Semicontinuous reactor HRT 14 days

Thermophilic-mesophilic temperature phased anaerobic digestion (TPAD) achieved 54\% VS

destruction compared to $44 \%$ in mesophilicmesophilic TPAD, with a $25 \%$ parallel increase in methane production.

\section{Application of microwave irradiation before AD}

turned out to be superior over thermal pre-treatment, which was confirmed by the release of sludge

Steel vessels equipped with a heating coil; microwave $30-100^{\circ} \mathrm{C} 1,5-8 \mathrm{~h}$

WAS
Batch tests, at $37^{\circ} \mathrm{C} 25$ days components and the increase in methane production.

Microwave irradiated sludge had a $35 \%$ increase in methane yield compared to digestion of untreated sludge. Finally, microwave pre-treatment at $70^{\circ} \mathrm{C}$ ensured absence of Salmonella spp. and E. coli as well as $50 \%$ decrease of $\mathrm{C}$. perfringens. 


\begin{tabular}{|c|c|c|c|}
\hline $\begin{array}{l}\text { Teflon jars heated in an } \\
\text { oven }\end{array}$ & $\begin{array}{l}120,140,160,180^{\circ} \mathrm{C} \\
15,30,45,60,75,90 \\
105,120,150,180 \mathrm{~min}\end{array}$ & WAS & $\begin{array}{l}\text { Batch tests, at } 37^{\circ} \mathrm{C} 28 \\
\text { days }\end{array}$ \\
\hline
\end{tabular}

The solid retention time could be reduced from 18-20

days to 12-14 days when high solid samples were pre-treated under $\mathrm{TH}$ at $140-160^{\circ} \mathrm{C}$ based on the corresponding results of acceleration of methane production after the treatment.

The results show that thermal pre-treatment at $175^{\circ} \mathrm{C}$

60 min significantly decreases viscosity, improves the municipal biomass waste dewatering performance.

$\begin{aligned} & \text { Stainless steel hydrolysis } \\ & \text { reactor with the oil bath }\end{aligned} \quad 175^{\circ} \mathrm{C} 60 \mathrm{~min}$
WAS $\quad \begin{aligned} & \text { Batch tests, at } 35^{\circ} \mathrm{C} \\ & 15 \text { days }\end{aligned}$
For WAS $25.2 \%$ of the organic compounds can be separated in the liquid phase after thermal treatment. WAS achieves a $34.8 \%$ methane potential increase and a doubled methane production rate after thermal pre-treatment.

A higher temperature and a larger treatment time are beneficial for organic and inorganic compounds

$\begin{array}{lll}70,80,90^{\circ} \mathrm{C} ; & \text { WAS } \quad \text { Batch reactors, 20days } \quad \begin{array}{l}\text { release. The efficiency of anaerobic digestion slightly } \\ \text { decreased for sludge pre-treated at } 70^{\circ} \mathrm{C} . \text { At higher } \\ \text { pre-treatment temperatures, the biogas production } \\ \text { increased significantly. }\end{array}\end{array}$
increased significantly.

\section{Pilot experimenta} apparatus with a vapor generator, hydrolysis reactor and decompression tank (with steam explosion effect)
The optimum conditions for thermal hydrolysis were $170^{\circ} \mathrm{C}$ and $30 \mathrm{~min}$, under which the VSS and viscosity reduced by $69.65 \%$ and $92.8 \%$ respectively while the SCOD increased by $21.90 \%$. Under the optimum conditions, no fecal coliforms were detected. 
Pilot plant with a steam

boiler, hydrolysis reactor and flash tank (with

automatic valves and

steam explosion effect)
Thermal pre-treatment $\left(175^{\circ} \mathrm{C}\right.$ and $\left.30 \mathrm{~min}\right)$ showed an important effect on the secondary sludge reaching an improvement of around $90 \%$ and $80 \%$ in the maximum production rate and the total biogas produced respectively. Comparing the sludge type,

Donoso-Bravo et al. thermal pre-treatment had a major effect on the secondary sludge, reaching an increase close to the $90 \%$.

Due to the thermal treatment, sludge flocs are disintegrated and sludge soluble COD increases by $40 \%$. The $\mathrm{AD}$ of the hydrolysed sludge generates $40 \%$

$175^{\circ} \mathrm{C} 30 \mathrm{~min}$

Mixed Continuous reactor, HRT more biogas in half the time, and removes $30 \%$ more biosolids. No coliforms were detected in the digested 2010
2010

$$
\text { sludge } 20 \text { days }
$$

sludge from the digester fed with hydrolysed sludge compared to a conventional digester. 


\subsubsection{Commercial thermal pre-treatment processes: a review}

At full-scale, difficulty comparing sites is attributable to site-specific variables involving: sludge type (configuration of waste water treatment plant; aeration sludge age; industrial loads); anaerobic digestion (configuration, retention time, operating temperature, quantity and type of mixing); cogeneration (configuration, size and efficiency) amongst others, like different commercial thermal hydrolysis processes.

There are several commercial thermal pre-treatment processes nowadays, for different applications and with different operating schemes. The technologies differ in many aspects, such as: operation (batch or continuous), reactor configuration, operating conditions (pressure, temperature, time), energy integration scheme (key for the process economics).

$>$ Cambi ${ }^{\circledR}$. It is a high-pressure steam pre-treatment process for anaerobic digestion of sludge and bio-waste, developed by the Norwegian company Cambi, in 1995 (Cambi). The principle of Cambi thermal hydrolysis is presented in Figure 10.

The technology consists of a series of reactors including a pulper vessel, a hydrolysis reactor and a flash tank. The system operates batchwise. Solids are first dewatered in centrifuges or beltpresses (to approximately $16-17 \%$ dry solids) and then transferred to the pulping vessel where are pre-heated to $80-97^{\circ} \mathrm{C}$ with recycled steam from the flashing of other parallel reactor. The preheated sludge is then pumped to the thermal hydrolysis reactor that operates at a temperature of $150-165^{\circ} \mathrm{C}(5-6$ bar) for about $20-30$ minutes with direct steam injection. After the thermal treatment, the sludge is transferred to the flash tank operating at atmospheric pressure. The hydrolyzed sludge is then cooled in a heat exchanger for mesophilic anaerobic digestion. The process is nowadays the most extended thermal hydrolysis technology worldwide (Steve and Panter, 2002; Panter and Kleiven, 2005; Hii et al. 2014). 


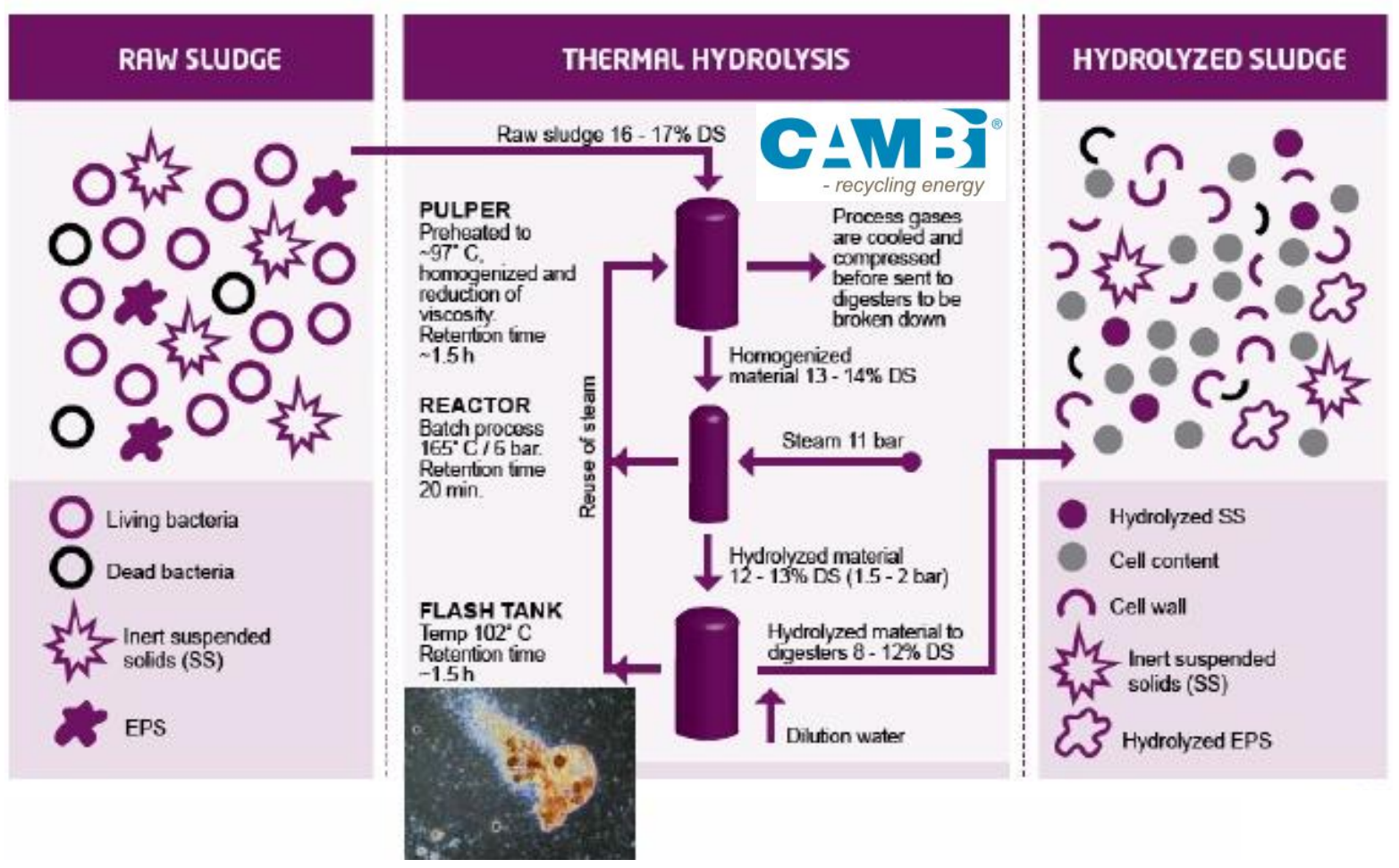

Figure 10. Principle of Cambi thermal hydrolysis process.

Biothelys ${ }^{\circledR}$. The technology is developed by the French Company Veolia (Veolia Water, Biothelys) for treating sludge prior to anaerobic digestion. The process is similar to the Cambi process, with the exception that the Biothelys system has no pulper or flash tank, just reactors of the same size operating in parallel (Figure 11).

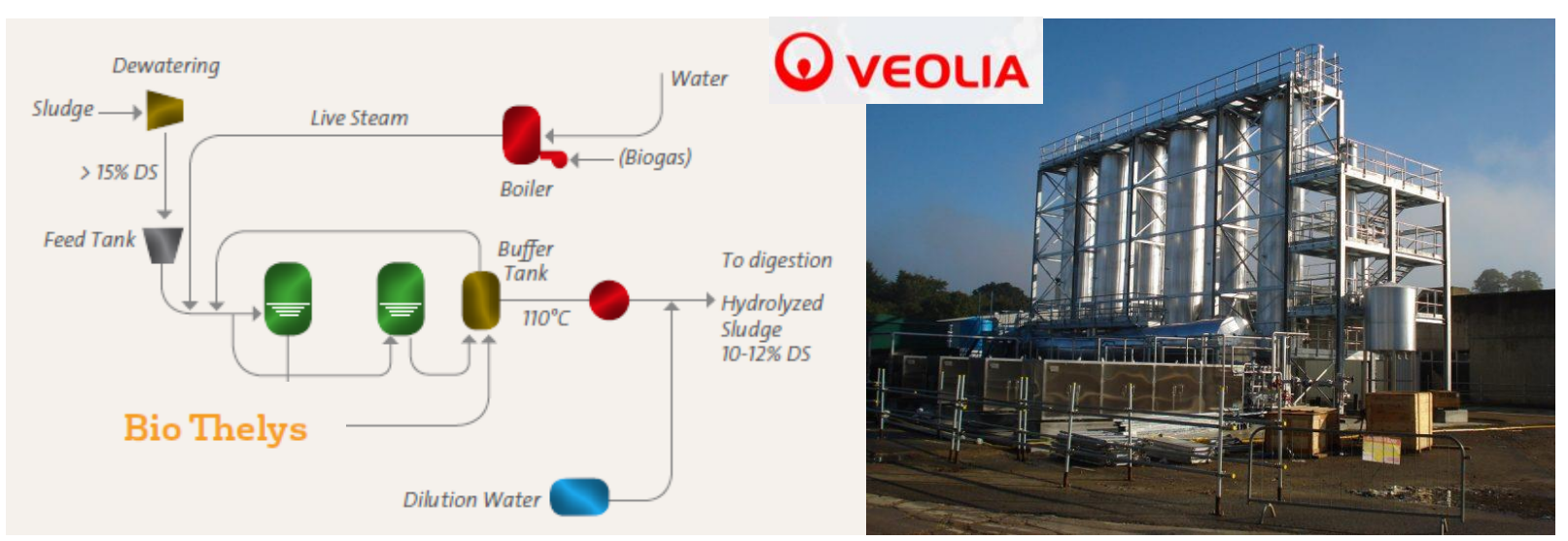

Figure 11. Schematic and full-scale plant of BioThelys process.

The process consists of 2 hydrolysis reactors working in parallel out of phase with each other, going through a $150-170$ minutes multi-step cycle. Dewatered sludge ( $>15 \% \mathrm{DS})$ is pre-heated in the reactor with recycled flash steam from the other reactor. Heating to the hydrolysis temperature $\left(150-165^{\circ} \mathrm{C} ; 6-8\right.$ bar $)$ is completed by injecting live steam, and after the desired 
retention time (approximately $30 \mathrm{~min}$ ) the pressure is reduced by flash. The hydrolysed sludge is stored and cooled, and fed to digestion (Veolia Water).

Exelys ${ }^{\circledR}$. It is a similar treatment process to Biothelys, sold by Kruger, a subsidiary of Veolia Water (Veolia Water, Exelys). This technology was developed as a continuous process that handles biosolids with dry solids content greater than $20 \%$ with the objective of minimizing steam consumption and reducing the operating cost compared to the batch (Figure 12).

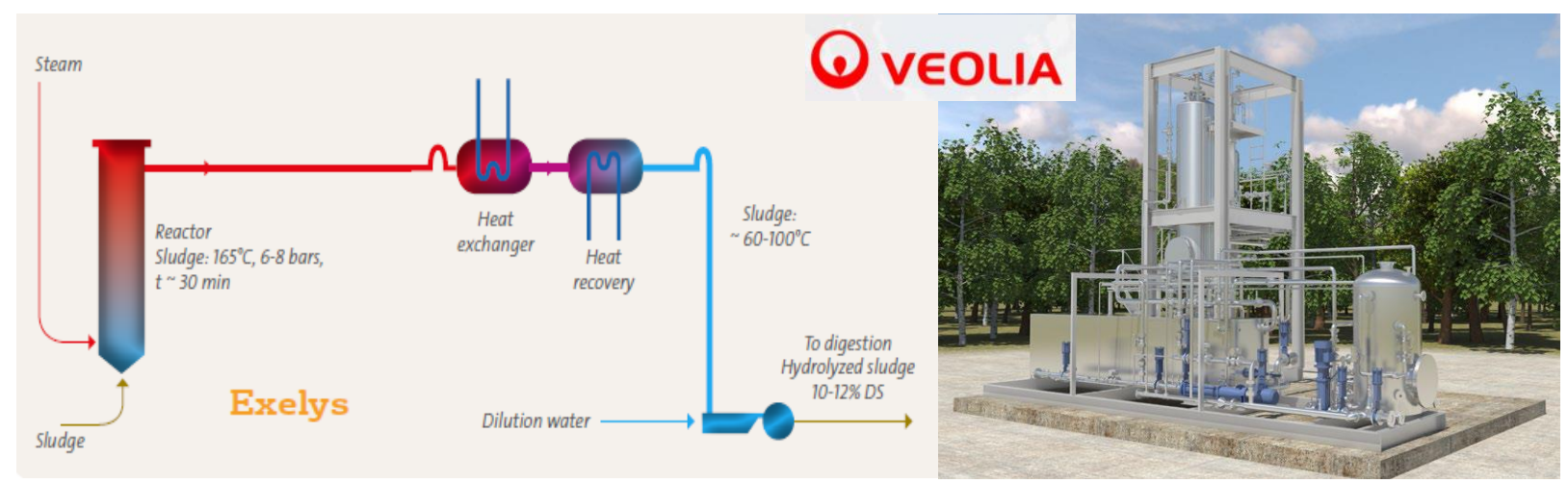

Figure 12. Schematic and full-scale plant of Exelys process.

Exelys operates under controlled temperature $\left(165^{\circ} \mathrm{C}\right)$, pressure $(9$ bar) and duration time (approximately 30 minutes) conditions. Dewatered solids and steam are continuously fed to the steam condenser section, where the steam condenses transferring heat to the biosolids raising the temperature to the desired value. Then the biosolids enter the reactor and flow at low velocity resulting in plug flow, and finally they go to a heat exchanger system where they cool before entering the digestion (Gurief et al., 2011).

Lysotherm®. The German company Eliquo STULZ, a subsidiary company of Eliquo Water \& Energy patented a thermal and pressure system of low viscous to medium-viscous organic sludge (dry solids $2-12 \%$ ), in particular for sewage sludge from WWTP. The operation is based in an indirect multi-stage thermal system (Figure 13). In a first stage (regenerative circuit) the sludge is preheated and then heated to the hydrolysis temperature $\left(140-175^{\circ} \mathrm{C}, 30-60 \mathrm{~min}\right)$ in a tubular reactor (thermal oil circuit). The regenerative circuit uses water as the transfer medium, recovering the heat from the hydrolysed sludge to preheat the sludge. The thermal oil in the process heat circuit is heated by the CHP exhaust gas heat (Eliquo Water and Energy). 


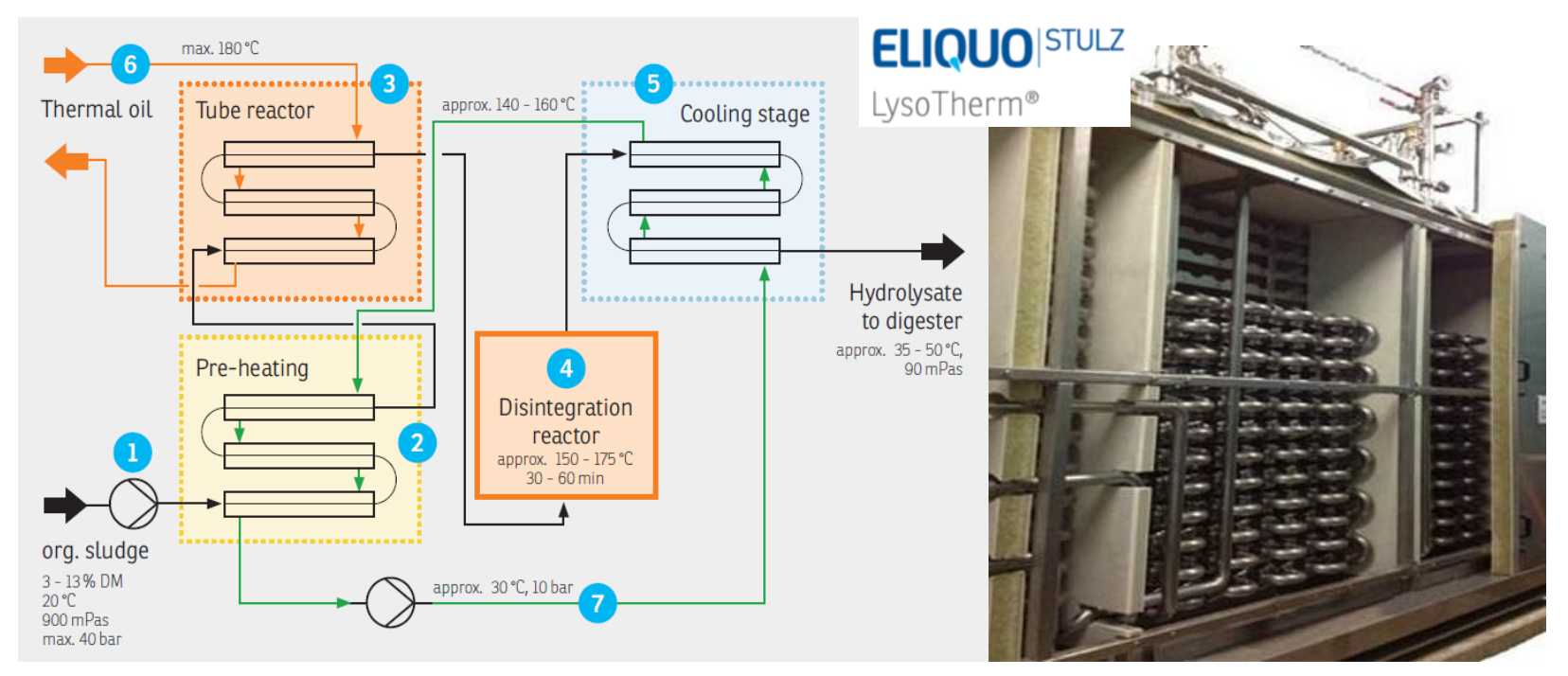

Figure 13. Schematic and full-scale plant of Lysotherm process.

Haarslev's Continuous Hydrolysis System (HCHS). In Danish company’s Haarslev Industries thermal hydrolysis system (Figure 14) the combined biosolids are dewatered to $17-22 \%$ and treated with saturated steam at a pressure of 6 bar with a temperature of $150-170^{\circ} \mathrm{C}$. Following the hydrolysis stage, a sudden decompression (or flashing) causes a destruction of the cell walls and frees the intracellular material for higher efficient digestion. Finally the sludge temperature is reduced to the mesophilic range by a second flash stage which results in further evaporative cooling (Haarslev Industries).

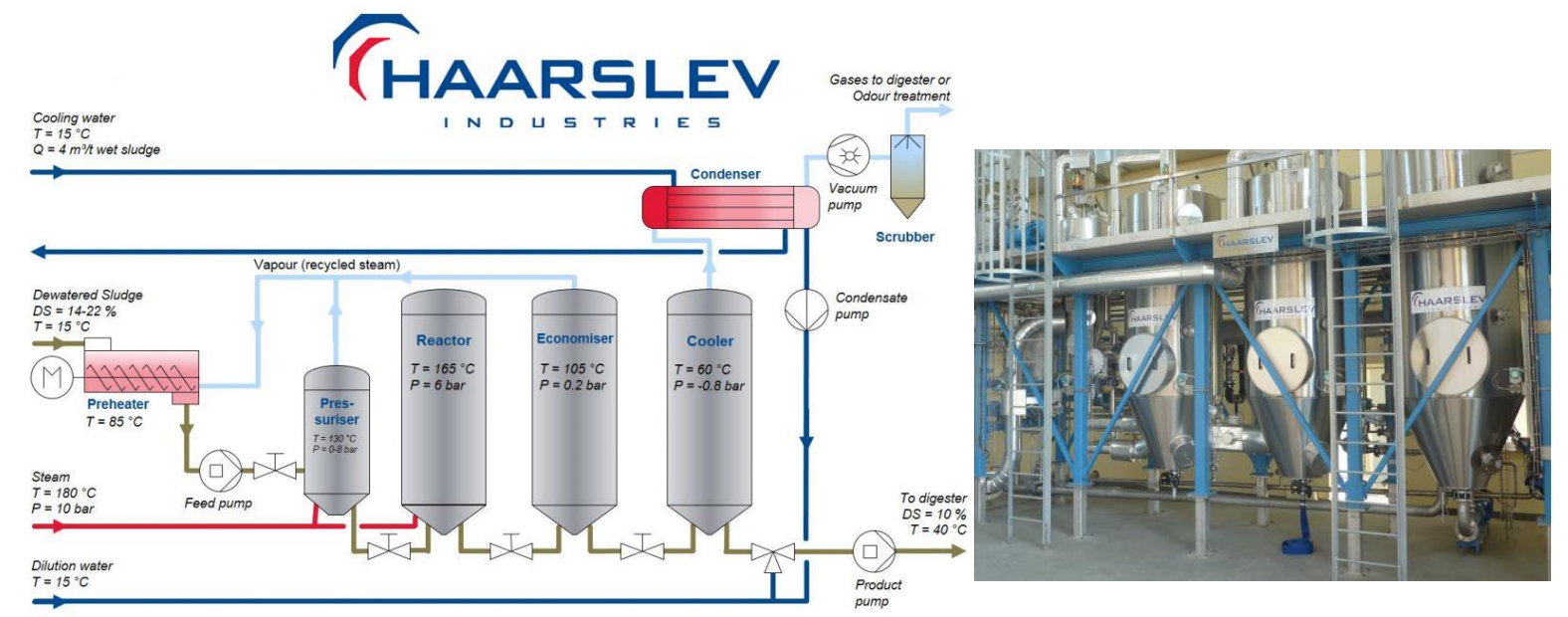

Figure 14. Schematic and full-scale plant of HCHS process.

Turbotec ${ }^{\circledR}$. A commercial company Sustec (Netherlands) offers Turbotec $I^{\circledR}$ as a continuous process for sewage sludge. After thickening or mechanical dewatering, the sludge is fed to the hydrolysis reactor heated with waste heat from the gas engine (Figure 15). Due to optimal heat recovery, a minimum amount of external heat needs to be supplied to the reactor. Crucial in the design of the continuous TurboTec ${ }^{\circledR}$ technology is the patented Mobius mixing/separation step 
which facilitates efficient heat exchange between raw and treated sludge, and enables the use of heat exchangers (Sustec).

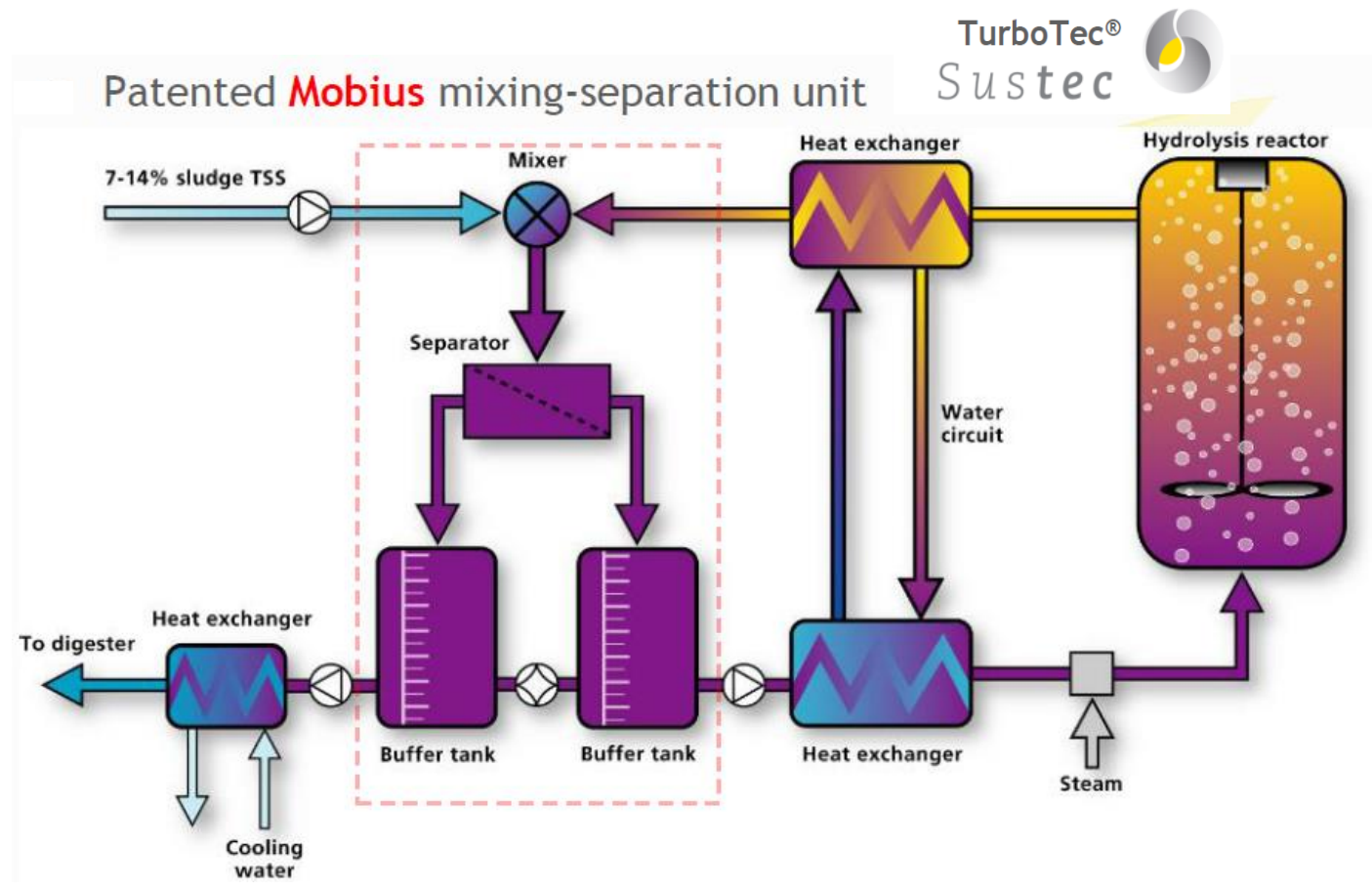

Figure 15. Schematic and full-scale plant of Turbotec process.

Aqualysis ${ }^{\circledR}$. Technology developed by Spanish company Aqualogy in collaboration with the University of Valladolid, offers a continuous thermal hydrolysis solution which combines the thermal treatment in a pressurized reactor with the steam-explosion effect, achieved by continuous decompression of the reactor content into a flash chamber (Figure 16). The continuous operation together with the plant configuration allows pre-heat the sludge in a feeding tank with the vapours generated and recirculated in the flash, thus decreasing the amount of live steam to be used (Aqualogy).

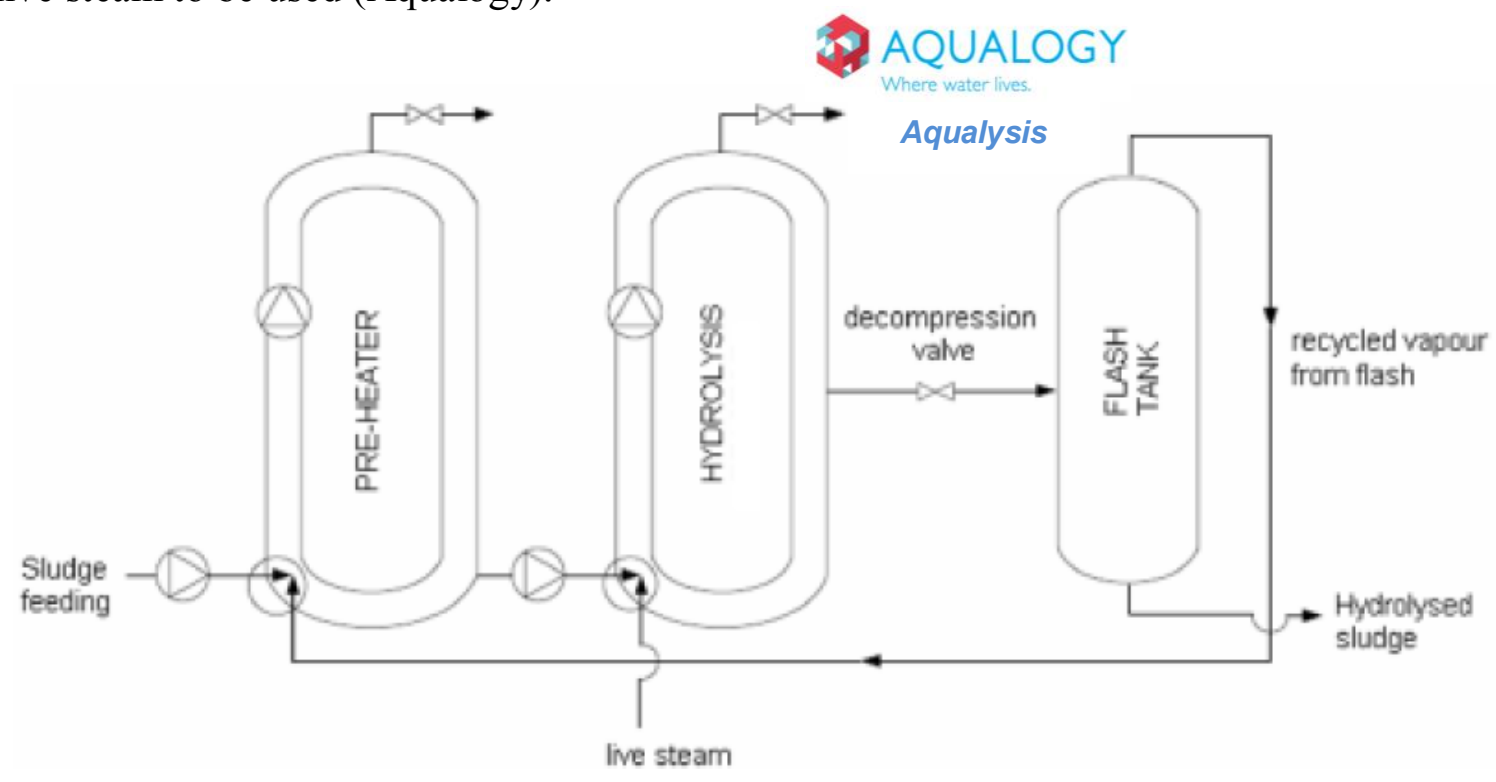

Figure 16. Schematic and full-scale plant of Aqualysis process. 
$\mathbf{T H}_{4}{ }^{+}$. An engineering company teCH$_{4}{ }^{+}$offers an innovative thermal hydrolysis process, where sludge is fed into dosification vessels and heated up with vapours from the heat recovery section for optimum heat integration and energy efficiency (Figure 17). Two parallel dosification vessels sequentially feed the organic material to pressurization tanks, where the waste is pressurized using compressed air or steam. This allows the organic material to flow through the process without the need for pumps or any other mechanical means. The pressurized material enters a mixer, where live steam is injected to achieve the temperature set point in an extremely rapid manner. This greatly minimizes the impact of the secondary reactions even at temperatures as high as $220^{\circ} \mathrm{C}$. The hot material is flashed to a regulation tank that provides a stable pressure throughout the system (Tech4plus).

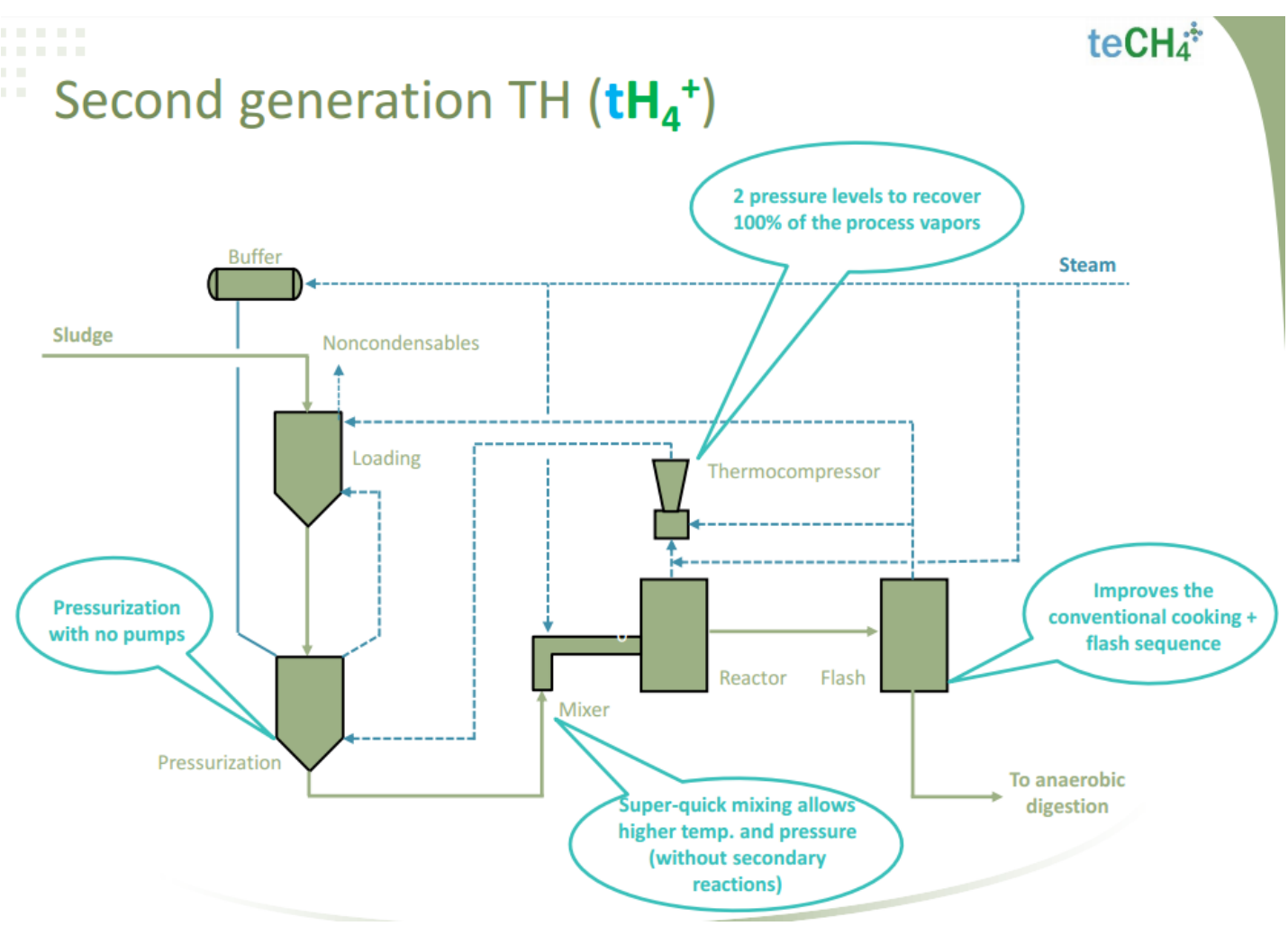

Figure 17. Schematic of $\mathrm{TH}_{4}{ }^{+}$process.

Thermal Pressure Hydrolysis (TPH). Dutch company HoSt supplies thermal pressure hydrolysis plants, where sludge is heated up to $140-180^{\circ} \mathrm{C}$ at a pressure of 4 to 10 bar, by the use of steam injections. After a retention time of $20-40$ minutes, the material is flashed. The flash vapor is recovered to minimize the energy consumption. The increased biogas production and re-using the heat from the flash vapour lead to a positive energy balance. The energy 
production is higher than the energy costs (HoSt). Full-scale plant of Thermal Pressure Hydrolysis process in Netherlands is presented in Figure 18.

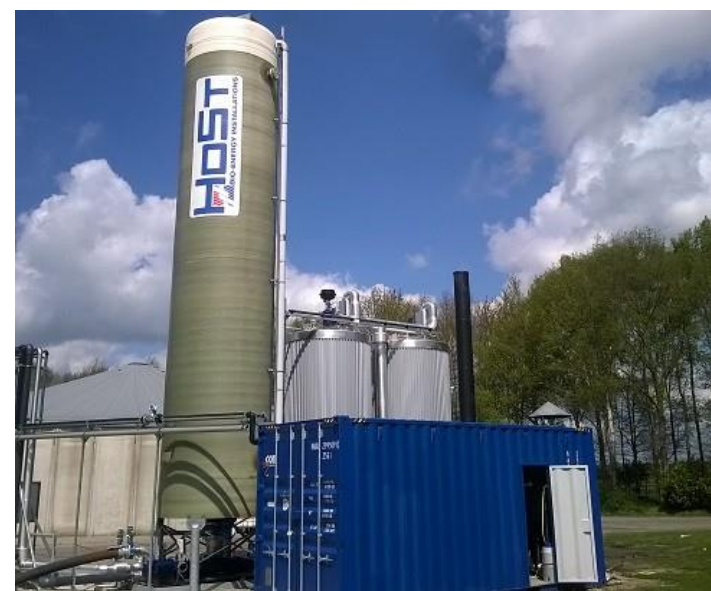

Figure 18. Full-scale plant of Thermal Pressure Hydrolysis process (Netherlands).

In order to roughly compare the existing processes, the available information is summarized in Tables 5, 6 and 7. Even there are still some knowledge gaps, some interesting aspects can be commented.

Although based on the same objective (to enhance the biodegradability of sludge) and operating principle (subjecting the sludge to high temperature and high pressure in a hydrolysis reactor) the operating schemes of the diverse thermal processes are different. Regarding the operating conditions, the technologies have three aspects in common: 1) the operation with concentrated biosolids, 2) no use of chemicals, and 3) operating conditions in the range of $140-220^{\circ} \mathrm{C}$ for $15-70$ minutes.

Table 5. Comparison of operation and performance reported for the commercial thermal pre-treatment processes.

\begin{tabular}{|c|c|c|c|c|c|c|c|c|c|c|}
\hline \multicolumn{2}{|c|}{ Technology } & Cambi & Biothelys & Exelys & Lysotherm & HCHS & Turbotec & Aqualysis & $\mathbf{T H}_{4}^{+}$ & ТPH \\
\hline \multirow{3}{*}{\multicolumn{2}{|c|}{$\begin{array}{l}\text { References to plants } \\
\text { Operating type } \\
\text { \%TS in feeding }\end{array}$}} & 41 & 7 & 4 & 3 & 2 & 2 & 1 & - & 1 \\
\hline & & Batch & Batch & Cont. & Cont. & Cont. & Cont. & Cont. & Cont. & N.A. \\
\hline & & $16-18$ & $>15$ & $>22$ & $2-12$ & $17-22$ & $10-12$ & 16 & $6-15$ & N.A. \\
\hline \multirow{4}{*}{$\begin{array}{l}\text { Operating } \\
\text { conditions }\end{array}$} & $\mathrm{T}\left({ }^{\circ} \mathrm{C}\right)$ & $150-165$ & 165 & 165 & $140-175$ & $150-170$ & $140-175$ & $165-180$ & 220 & $140-180$ \\
\hline & P (bar) & $5-6$ & $6-8$ & 9 & $5-10$ & $7-8$ & $4-6$ & $7-10$ & $12-14$ & $4-10$ \\
\hline & $\mathrm{t}(\min )$ & $20-30$ & 30 & 30 & $30-60$ & 20 & $30-70$ & $15-30$ & $<5$ & $20-40$ \\
\hline & Flash & + & - & - & + & + & - & + & +2 & + \\
\hline \multicolumn{2}{|c|}{$\%$ biogas increase* } & $100-150$ & $30-50$ & $30-50$ & $20-50$ & + & 35 & 30 & 30 & + \\
\hline \multicolumn{2}{|c|}{$\%$ VS removal } & $60-70$ & $25-35$ & $25-35$ & + . & + & 30 & 30 & + & + \\
\hline \multicolumn{2}{|c|}{ Pasteurization } & + & + & + & + & + & + & + & + & + \\
\hline \multicolumn{2}{|c|}{$\begin{array}{l}\% \mathrm{DS} \text { in dewatered } \\
\text { cake }\end{array}$} & $30-40$ & 35 & $22-30$ & $25-35$ & + & $>30$ & + & + & + \\
\hline \multicolumn{2}{|c|}{ Viscosity reduction } & + & + & + & + & + & + & + & + & + \\
\hline
\end{tabular}

* respect to conventional

N.A.: not available

Table 6. Comparison of thermal pre-treatment technologies ( $\checkmark$-positive; $\boldsymbol{x}$ - negative). 


\begin{tabular}{l|c|c|c|c|c|c}
\hline Technology & $\begin{array}{c}\text { Steam } \\
\text { explosion }\end{array}$ & $\begin{array}{c}\text { Heat } \\
\text { exchangers }\end{array}$ & Pumps & Maintenance & Footprint & $\begin{array}{c}\text { Energy } \\
\text { integration }\end{array}$ \\
\hline Cambi & Yes & No & Yes & $\mathbf{x}$ & $\mathbf{x}$ & $\mathbf{x}$ \\
Exelys & No & Yes & Yes & $\boldsymbol{x}$ & $\mathbf{x}$ & $\mathbf{x}$ \\
Lysotherm & Yes & Yes & Yes & $\mathbf{x}$ & $\mathbf{x}$ & $\mathbf{x}$ \\
HCHS & Yes & No & No & $\checkmark$ & $\checkmark$ & $\mathbf{x}$ \\
TurboTec & No & Yes & Yes & $\mathbf{x}$ & $\mathbf{x}$ & $\mathbf{x}$ \\
Aqualysis & Yes & No & Yes & $\mathbf{x}$ & $\checkmark$ & $\mathbf{x}$ \\
$\mathrm{TH}_{4}^{+}$ & Yes (2) & No & No & $\checkmark$ & $\checkmark$ & $\checkmark$ \\
\hline
\end{tabular}

Table 7. General features of thermal hydrolysis technologies.

\begin{tabular}{|c|c|}
\hline Biogas production & $\begin{array}{l}\text { Keeping digestion HRT constant, biogas yield increases by } 40-60 \% \text { for } \\
\text { waste activated sludge (WAS) and by } 10-25 \% \text { for mixed sludge }\end{array}$ \\
\hline $\begin{array}{l}\text { Digested sludge } \\
\text { (biosolids) }\end{array}$ & $\begin{array}{l}\text { Reduced volumes (proportional to biogas yield increase) } \\
\text { Lower viscosity } \\
\text { Improved dewaterability (DS > 30\%) } \\
\text { - Pasteurization: EPA Class A; no pathogen regrowth. Agricultural } \\
\text { application } \\
\text { No odors }\end{array}$ \\
\hline Anaerobic process & $\begin{array}{l}\text { Reduced energy consumption in mixing } \\
\text { Higher DS concentration in feed }(10 \% \mathrm{DS}) \\
\text { Higher organic loading rates }\left(4 \mathrm{~kg} \mathrm{SSV} / \mathrm{m}^{3} \cdot \mathrm{d}\right) \\
\text { - No foam formation } \\
\text { - Increased elimination yield of emergent compounds } \\
\text { Higher COD and } \mathrm{N} \text { concentration in dewatering recycle }\end{array}$ \\
\hline
\end{tabular}

However, the process configuration, heating mechanism and energy recovery scheme varies in all the technologies. While the origin of the thermal pre-treatment was a batch process (Cambi ${ }^{\circledR}$ and Biothelys $\left.{ }^{\circledR}\right)$, the more recent developments claim continuous operation, searching for more costeffective process by exploiting the energy recovery. To the same, the proposal of second-generation technologies (such as $\mathrm{tH}_{4}^{+}$) point to reduce operating time (reduced footprint) by increasing hydrolysis temperature and exploiting the steam explosion effect.

Without a thermal mechanism of the thermal hydrolysis process, which is included in all the commercialized technologies reviewed, sludge flashing (or steam explosion) is still not a common operating condition. Just two companies (Cambi and teCH4+) highlighted its importance for the process, while others just mentioned its' introduction to the process. When a hot, pressurized liquid is suddenly decompressed, flash boiling occurs. In the case of sludge, the water contained in the external polymer structure and inside the cells partially vaporizes, resulting in a cell structure fracture, both internally and externally. For temperatures of $170^{\circ} \mathrm{C}$ and times in the $0-30$ min range, 
Donoso-Bravo et al. (2011) concluded that the impact of steam explosion is much more significant than the thermal effect (Tech4plus). An effect of thermal hydrolysis and steam explosion on sludge state are demonstrated in Figure 19 (Menco, 2012). Obvious changes are obtained in sludge structure when thermal pre-treatment with or without steam explosion is applied to sludge pre-treatment.
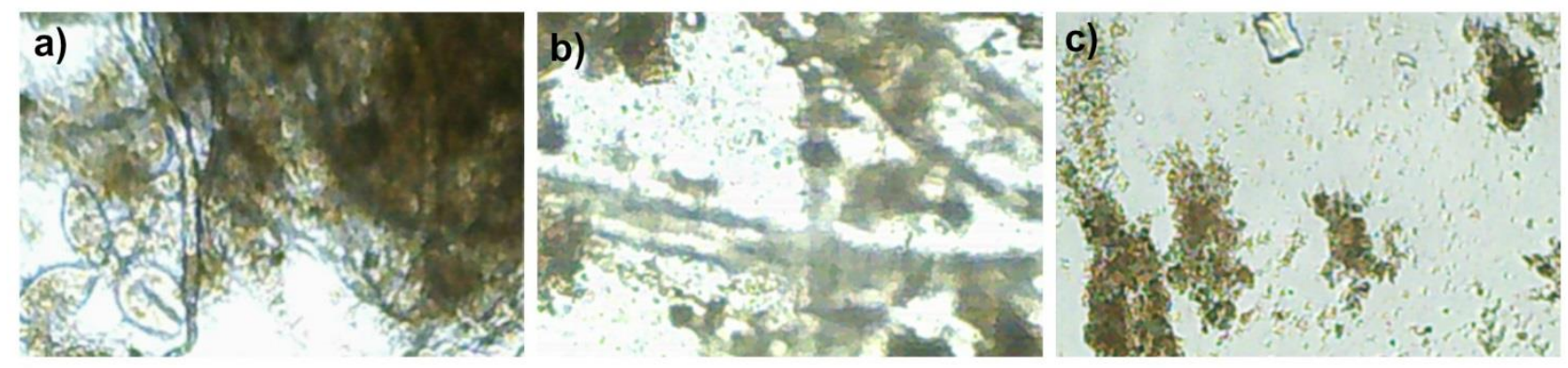

Figure 19. a) Thickened mixed sludge without pre-treatment; b) thickened mixed sludge after thermal hydrolysis at $165^{\circ} \mathrm{C}$ for 20 min without steam explosion; c) thickened mixed sludge after thermal hydrolysis at $165^{\circ} \mathrm{C}$ for $20 \mathrm{~min}$ and steam explosion. Photo $400 \times 550$ micras (Environmentindex).

These photos once more confirm the beneficial effect of thermal hydrolysis and, moreover, of steam explosion on sludge pre-treatment, when a destruction of the cell walls occurs thus releasing the intracellular material for higher efficient of anaerobic digestion.

Regarding the process performance, globally most of the technologies offer the same qualitative benefits: enhancement of biogas production and VS removal, pasteurization, reduction of viscosity and better dewaterability.

Finally, scarce references to disadvantages have been found. Some issues reported by Cambi are: system complexity, need for high level operator training, shutdowns (regulatory inspections and approved maintenance), and increase in soluble inert fraction and ammonia in the recycled stream. While not mentioned, all the technologies may also be subjected to these and even more concerns.

\subsubsection{General discussion of thermal hydrolysis applicability}

Thermal hydrolysis has proven to be a one of the most successful approach to making sewage sludge more amenable to anaerobic digestion. A substantial number of laboratory studies and fullscale applications (there are 75 facilities of which 39 are operating and the remaining are in various stages of design (Barber 2016)) over the years have documented many process advantages. The most investigated are presented with approximate values for WAS:

Improves solubility of COD ( $25-40 \%$ of WAS);

Significantly improves the biodegradability of sludge $(30-60 \%$ more biogas; VSR increase of $60 \%$; biodegradability $60 \%$ ); 


\section{$\checkmark$ Decrease particle size;}

$\checkmark$ Increases rate of biogas production;

$\checkmark$ Reduce sludge viscosity (decrease of app. 90\%);

$\checkmark$ Allows significantly higher loading rates (DS $8-12 \%$ ) resulting in smaller digesters with better mixing;

$\checkmark$ Improves dewaterability of the final sludge (DS $>30 \%$ );

$\checkmark$ Removes digester foaming;

$\checkmark$ Ensures sludge disinfection (Class A);

$\checkmark$ Reduces odour;

$\checkmark$ And others.

Sludge treatment process modification, innovative technologies integration within WWTP (like thermal pre-treatment), achieved considerable improvement of the anaerobic digestion and many other advantages - everything sounds unexceptionable. But all process changes, even if they are positive, with respect to the previous process configuration, have consequences for the downstream sludge processing and overall WWTP operation. Thus, several questions appear - how does the integration of thermal hydrolysis pre-treatment affect the global process of WWTP? How does the introduction of novel technology, that significantly consumes energy, affect the WWTP energetically?

Answers to these questions could vary quite widely, depending on many variables involved at a WWTP. Different regions, different waste water treatment plant sizes, different configurations and technologies of WWTP and thermal pre-treatment unit, final objective of the pre-treatment ( hydrolyze only the secondary sludge when the aim is to increase biogas yield and reduce biosolids volume or hydrolyze both the primary and the secondary sludge when the additional objective is to pasteurize the biosolids), sludge type and concentration used in a thermal hydrolysis, anaerobic digestion conditions, energy recovery and others could greatly adjust the outcomes. However, a general estimation could be performed in accordance with the information existing in a literature and data from the WWTP with the full scale thermal hydrolysis plants.

Drivers for thermal hydrolysis installation are geographically market driven but typically include: increased loading rates (to minimize size of new digestion plants, or maximize use of existing facilities); improved sludge cake dewaterability which reduces downstream transport and processing cost; increased production of renewable energy, and sterilization of sludge. When the innovative technology (in this case thermal hydrolysis) is integrated to the sludge treatment line, the 
responsible process evaluation should be done in order not to increase the overall consumption of energy or, at the best case, make or maintain WWTP energy self-sufficient. Energy self-sufficient WWTPs commonly refer to plants generating $100 \%$ or more of their energy requirement for operation solely from the energy embedded in the water and wastes they treat with zero external energy supply (Gu et al. 2017). Thus, it is important to optimize the quantity of the sludge being processed and the process temperature, while the selection of these two parameters plays a key role on the process economics.

As the sludge moiety has a lower specific heat capacity than water ( $\mathrm{Xu}$ and Lancaster 2009), increasing the dry solids of the sludge will intrinsically reduce energy requirements. Typically, the sludge dry solids are thickened to approximately 15 - 18\% DS before TH, but further thickening may incur heat transfer limitation as well as practical processing concerns. Rheology change due to thermal hydrolysis is arguably the most important consequence of the technology on sludge treatment. Sludge rheology is a useful parameter for operation and monitoring of the anaerobic digestion and downstream sludge processes, and the reduction of viscosity means that the sludge is more fluid so that a higher solid concentration of $8-12 \%$ can be fed to the digester. Conventional anaerobic digestion commonly treats sludge with a total solids content of $2-5 \%$, because the high viscosity of sludge at greater total solids hampers mixing and mass transfer. Moreover, if the viscosity of sludge is decreased by thermal pre-treatment, the energy required for pumping and stirring is lessened and the mass transfer is improved. To the same, improved sludge dewaterability decreases polyelectrolyte consumption, and the most important, biosolids amount to be disposed together with the downstream operating cost.

As thermal hydrolysis allows an increase in sludge solubility due to the microbial cells and extracellular polymeric substances disintegration, improvement in sludge biodegradability during anaerobic digestion is obtained. Moreover, due to the enhanced hydrolysis stage, it is possible to accelerate the rate of biogas production, such that the same amount of biogas can be produced in a shorter time. For example, running digestion plants at approximately 10 rather than 20 days retention time may be preferable when coupled with thermal hydrolysis. This relevant advantage lets to minimize construction of anaerobic digestion plant thus also maximizing overall energy balance around digestion.

In addition, thermal pre-treatment has the benefit of sterilization and sanitation by killing most of the pathogens and bacteria in the feedstock. Therefore, the sludge after enhanced hygienization of thermal process can not only comply with the European Union (EU) policy on the elimination of pathogens, but also reach class A biosolid standard of the US Environmental Protection Agency (EPA), making it more suitable for subsequent land application. With this classification, no land 
application restrictions exist, which provides plant owners long-term certainty of biosolids disposition.

It is well known that wastewater is commonly considered a potential energy resource because it contains a wealth of organic matter and carbon energy. The main energy source in a WWTP is the biogas produced during anaerobic digestion. Furthermore, advanced anaerobic digestion with thermal pre-treatment led to a $30-60 \%$ biogas production increase. This biogas can be directly used to produce electrical and thermal energy or, after upgrading, it can be transformed into biomethane and be injected in the natural gas grid or used by the automotive sector.

However, WWTPs are frequently recognized as the largest independent energy consumers managed by municipalities (Gu et al. 2017). Most major stages in WWTP, such as the collection and conveyance of wastewater, physical and chemical treatment, biological treatment, sludge treatment and discharge, require considerable energy. In a conventional WWTP, $25-40 \%$ of operating costs are attributed to energy consumption (Panepinto et al. 2016). Sludge treatment is a very energyintensive process in WWTPs. Research focusing on 10 WWTPs in Greece, with 15,000-4,000,000 population equivalents (PE), indicated that sludge treatment sections were significant energy consumers, accounting for about $8 \%$ of the total energy consumption of these WWTPs (Mamais et al. 2015). Therefore, the integration of thermal hydrolysis within WWTP should improve the anaerobic digestion performance in an energy-favorable way as the energy sufficiency of waste water treatment plants is now becoming a topic of interest. For this, an obvious way to reduce the power consumption is to generate it internally from the digesters biogas. This not only reduces the operating costs, but also utilizes a renewable energy source and displaces fossil fuels (FernándezPolanco and Tatsumi 2016).

A graphical scheme of reported effects of thermal hydrolysis and their influences are below enclosed. 


\section{Effects of thermal pre-treatment and their influences}

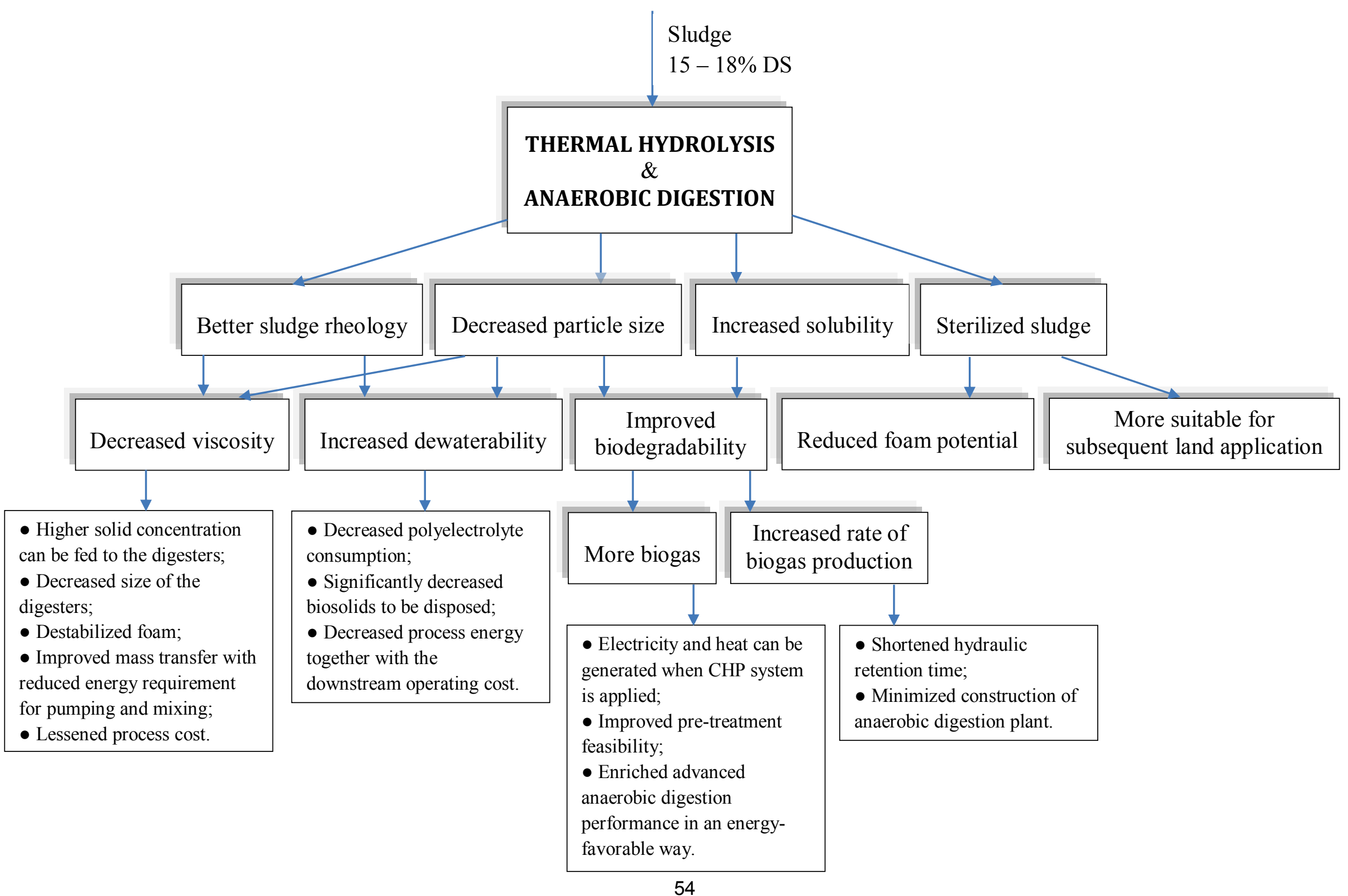


Combined Heat and Power (CHP) technologies generate both electricity and heat from a single fuel source at the same time. CHP systems using anaerobic digestion of sludge is the technology most adopted in the existing energy self-sufficient WWTP (Gu et al. 2017). This system (Figure 20) is an efficient way to produce electricity (E.E) and recover heat in a gaseous stream at $400^{\circ} \mathrm{C}$ (exhaust gases, E.G) and in a liquid stream at low temperature (hot water, H.W). Typically, 15\% of the biogas energy is lost and, from the rest, $35 \%$ is converted into electric energy and $65 \%$ into thermal energy (30\% in E.G and 35\% is H.W). Unfortunately, most of the times, just the electric energy is useful and generates profit, which only represents a $30 \%$ of the total energy contained in the biogas.

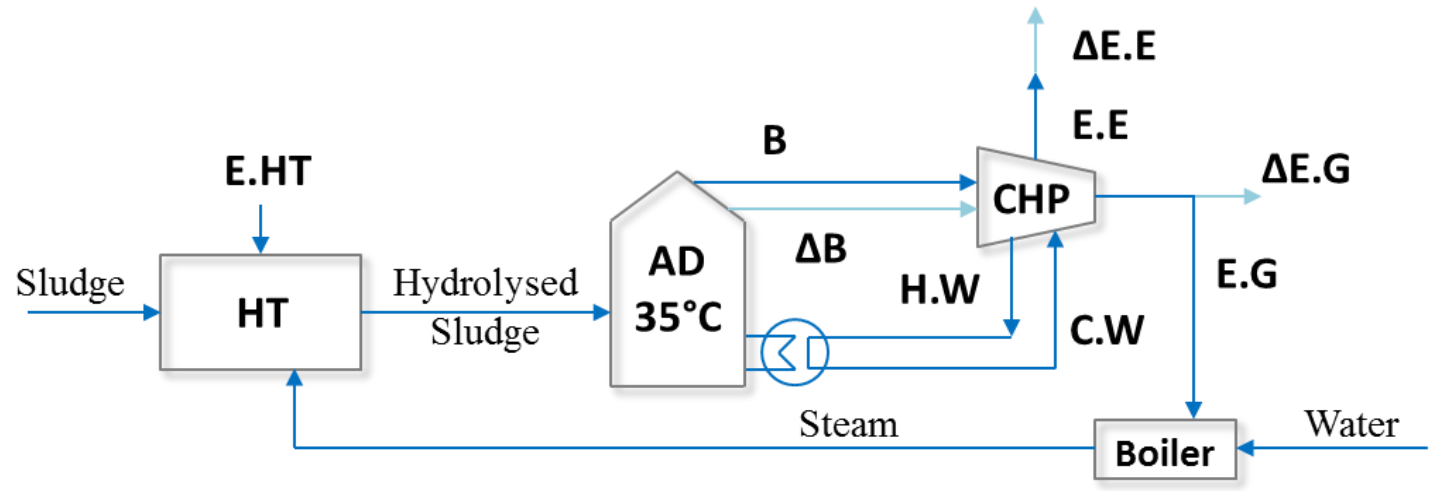

Figure 20. Schematic of energy recovery from biogas with a CHP system.

Therefore, when a pre-treatment is implemented before anaerobic digestion, its energy requirements (E.HT) should be lower than the increase of electric energy that produces $(\Delta \mathrm{E} . \mathrm{E})$ in order to assure an energetically self-sufficient process.

It is immediately noticeable that the extra biogas produced in the digestion will directly influence the pre-treatment feasibility, but the amount of recovered energy in terms of heat or electricity to the pre-treatment is what would lead to an energy integrated process. For this reason, the most favorable scenario consist of thermal hydrolysis pre-treatment with a recovery of heat from the flash vapours (Figure 21) to pre-heat the sludge that leads to considerably saving the energy consumption. 


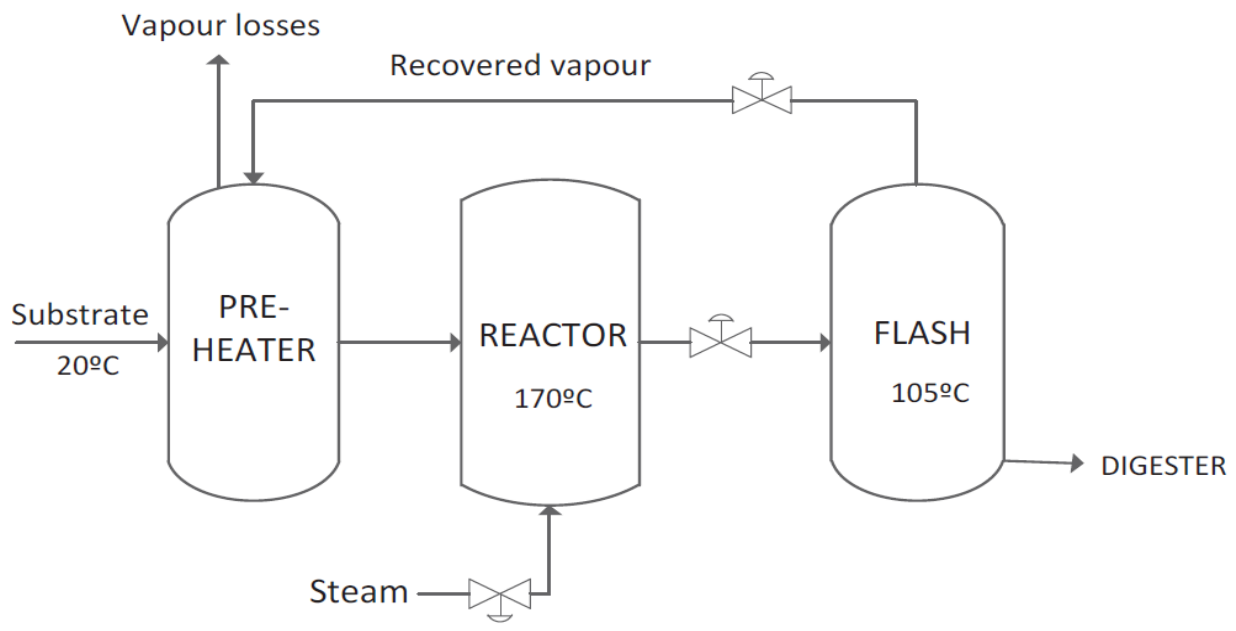

Figure 21. Schematic of TH with a heat recovery the flash vapours.

Further, the biogas is burned in a combined heat and power system providing three main streams:

$>$ Electrical green energy (E.E) - to be sold, providing net benefits;

Hot exhaust gases (E.G) - waste stream which heat can be recovered in a boiler to produce steam for the thermal hydrolysis pre-treatment (natural gas is not anymore needed if the heat is sufficient);

Hot water $(H . W)$ - it can be used to heat the digester (Figure 20).

From that, it is clear that while the operation of the conventional AD (without thermal pretreatment) represents a cost, due to considerable high requirement of energy and greatly expensive sludge downstream transport and processing, the scenarios of advanced digestion drive to a benefit.

Combining primary benefit of the advanced anaerobic digestion technology, that involves changes in sludge rheology, together with energy benefit around anaerobic digestion due to additional biogas production and CHP systems application, and consequent significant energy benefit due to improved dewaterability, which reduces downstream transport and processing requirements, is elucidated that thermal hydrolysis of sludge has a high potential to be fully integrated in WWTP with a complete energy recovery and self-sufficiency.

\subsection{Alternative approaches to conventional thermal hydrolysis schemes}

\subsubsection{A novel process configuration: Intermediate Thermal Hydrolysis}

While the digester throughput is increased by utilising the thermal hydrolysis process, the biogas yield has not increased significantly or the expected increase in volatile solid reduction (VSR) has 
not been realised (Shana et al. 2011). Existing sludge digestion technologies are not as efficiency as they should be in reducing sludge organic matter and enhancing biogas production. The sludge recycled to land often contains about $60-66 \%$ organic matter and even with $\mathrm{TH}$, around $50 \%$ of the initial biodegradable organic matter is disposed (Shana et al. 2012). This remaining quantity of energy rich sludge could be further subjected to anaerobic digestion while optimising the sludge treatment process, investing in novel treatment technologies or changing existing process configurations. These reforms would lead to an obtainment of additional biogas and reduction of sludge volume for tinkering, improvement of quality of digested cake, hence reducing the carbon footprint and leading to more sustainable overall sludge treatment process.

For this reason, a novel sludge treatment configuration, which consists of an intermediate step of thermal hydrolysis (ITH) of digested sludge before a second digestion, was developed. The ITH pretreatment (Figure 22), consist of a conventional mesophilic anaerobic digestion (AD) followed by $\mathrm{TH}$ and a second stage of mesophilic AD of the resulting stage.

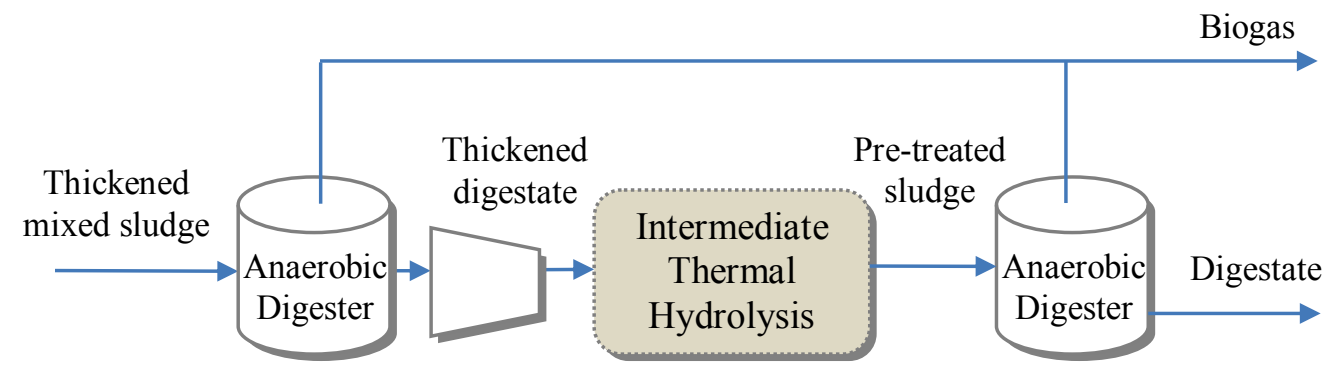

Figure 22. Schematic of an Intermediate Thermal Hydrolysis.

Very limited information exists on the pre-treatment or co-treatment of digested sludge and the re-digestion of already digested sludge, but some researches have already confirmed that ITH dealt well with an already digested sludge and achieved enhanced overall sludge digestion process efficiency. In the study of Nielsen et al. (2011) different types of pre-treatments under moderate thermal $\left(80^{\circ} \mathrm{C}\right)$, high thermal $\left(130-170^{\circ} \mathrm{C}\right)$ and thermochemical $\left(170^{\circ} \mathrm{C}, \mathrm{pH} 10\right)$ conditions were compared with inter-stage treatments under the same conditions. Next they reported that comparing pre-treatment with inter-stage treatment the latter method was superior or comparable under all tested conditions, with regard to improvement of the final methane yield. Shana et al. (2011) and Mills et al. (2013) also confirmed that the novel ITH combination produced $20 \%$ more biogas compared to TH pre-treatment. In the study of Ortega-Martinez et al. (2016) the biodegradability of mixed sludge rose up to $62 \%$ from $36 \%$ when the digestate was thermally pre-treated and then digested again. 


\subsubsection{A variation to the thermal process: Gas explosion pre-treatment}

In parallel with the thermal hydrolysis ("steam explosion") process, "gas explosion" technology - Cellruptor as a pre-treatment method to improve anaerobic digestion is similarly used. The main difference of the processes is that instead of the steam used in thermal pre-treatment, biogas is applied for the substrate pressurisation in an alternative technology.

The Cellruptor process has been developed by Eco-Solids International Limited (UK) (first installation in 2010) as a cell disruption process, principally for the pre-treatment of feedstock prior to the anaerobic digestion of the sludge. Cellruptor uses a unique pressure swing technology (few pressure-depressure cycles) to open up biosolids materials, such as waste activated sludge or crop biomass, to increase the rate of subsequent fermentative processes, including anaerobic digestion. Full-scale plant is presented in Figure 23.

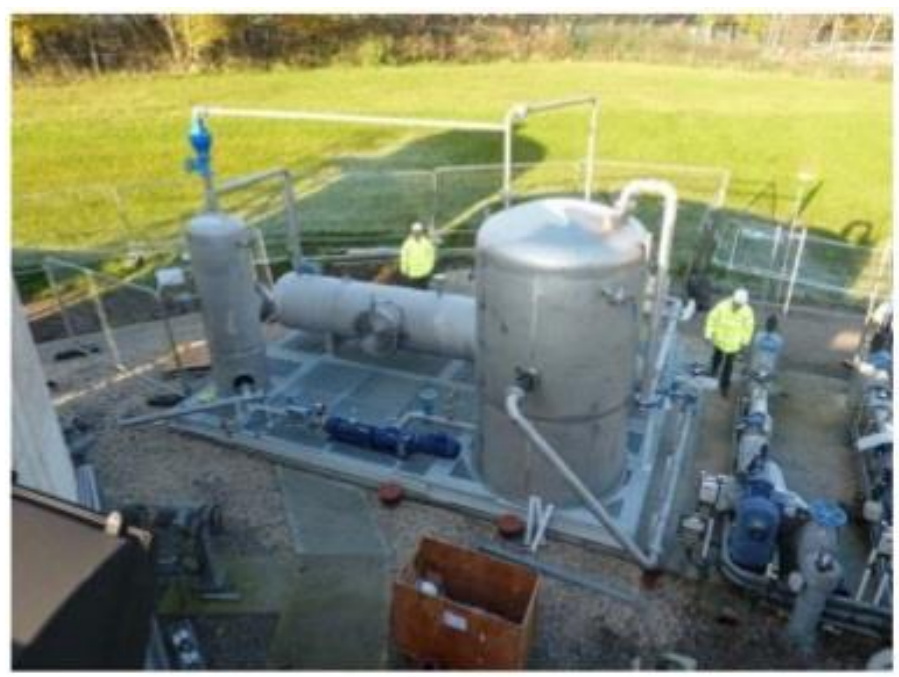

Figure 23. Full-scale plant of Cellruptor process.

For anaerobic digestion, the feedstocks, ideally containing up to $10 \%$ solids, compressed to a pressure between 3 and 6 bar. Biogas (or other soluble gas like $\mathrm{CO}_{2}, \mathrm{CH}_{4}$ or $\mathrm{NH}_{3}$ ) is then introduced to the sludge stream. The properties of the gas are such that the gas is soluble in the sludge stream. Through subsequent mixing, equilibration and depressurisation steps, the continuous process results in dissolved gases "exploding" the cellular material. This rapid decompression causes exceeding high shear rates and irreversible cell rupture, decreasing particle size, and releasing the interstitial water to the sludge stream (Jolly et al. 2009). This process allows the resultant sludge to be more readily converted to biogas in the digester.

Cellruptor's cell-disintegration technology dramatically improves the process economics of anaerobic digestion. It is a simple system that enhances the reduction of volatile solids to increase overall gas generation - without introducing additional large energy requirements or complex operating process equipment. Depending on the nature of these feedstocks, biogas production rates 
may increase in the range $5-20 \%$. And unlike some alternative technologies that require high pressures, skid-mounted Cellruptor only needs a maximum of 10bar. Additional gas also means less digestate solids to be stored, moved and transported, with Cellruptor (which in some cases has a rapid payback of less than 24 months) improving the throughput of the treatment works and prolonging the life of capital equipment.

Features:

$\checkmark$ Low power requirement

$\checkmark$ Simple operation and maintenance

$\checkmark$ Proven effective cell disruption technology

$\checkmark$ Lower volatile solids in the digestate

$\checkmark$ Homogeneous feed for anaerobic digestion

$\checkmark$ Lowest capital investment cost for proven pre-treatment technologies

$\checkmark$ Maximise the net energy gain from increased biogas production

$\checkmark$ No high cost equipment servicing or replacement

$\checkmark$ Guaranteed effect of pre-treatment means increased downstream digestion kinetics

$\checkmark$ More mineralised digestate leads to lower odour generation potential and potentially improved dewatering

$\checkmark$ More stable digestion process with lower operating and chemical additive costs

$\checkmark$ Lower capital threshold and faster payback period (Ecosolids).

Despite of no relevant literature available, some results of the "gas explosion" technology can be searched out in investigation works. Zheng et al. (1998) compared $\mathrm{CO}_{2}$ explosion with steam and ammonia explosion for pre-treatment of recycled paper mix, sugarcane bagasse, and re-pulping waste of recycled paper and found that $\mathrm{CO}_{2}$ explosion was more cost-effective than ammonia explosion. Further, it did not cause the formation of inhibitory compounds that could occur in steam explosion. An increase in pressure facilitated faster penetration of $\mathrm{CO}_{2}$ molecules into the crystalline structures, producing more glucose after the explosion. Because $\mathrm{CO}_{2}$ explosion is operated at low temperatures, it does not cause degradation of sugars such as the degradation of sugars observed with steam explosion due to the high temperature involved. Ma et al. (2011) performed a $\mathrm{CO}_{2}$ pretreatment study with kitchen waste. The substrate was pressurized to 10 bar with $\mathrm{CO}_{2}$ as pressurizing gas. After few minutes of contact time, the depressurization of the reactor to atmospheric pressure (1 bar) was performed by quick release of the $\mathrm{CO}_{2}$ gas. The solubilisation achieved was just $12 \%$, however the cumulative biogas production was the highest, corresponding to $0.52 \mathrm{~L} / \mathrm{gCODt}$ 
removed. This discrepancy between the solubilisation effect and the biodegradability was explained by the dependence on the mode of pressurization (number of pressure-depressure cycles) and the pressure applied. Thiruvenkadam (2011) in his master thesis reported Cellruptor pre-treatment (10 bar; $\mathrm{CO}_{2}$ ) being an effective technology in increasing the biogas production, especially with dry substrates, such as maize, hay, etc., than sewage sludge. From the batch experiments, Cellruptor pretreatment showed maximum and minimum increase of methane yield in hay (32\%) and dewatered waste activated sludge sludge (2\%) respectively.

\subsection{References}

1. Abe, N., Tang, Y.Q., Iwamura, M., Morimura, S., Kida, K. (2013). Pretreatment followed by anaerobic digestion of secondary sludge for reduction of sewage sludge volume. Water Science and Technology 67 (11), 2527-2533.

2. Abelleira, J., Pérez-Elvira, S.I., Portela, J.R., Sanchez-Oneto, J., Nebot, E. (2012). Advanced thermal hydrolysis: optimization of a novel thermochemical process to aid sewage sludge treatment. Environmental Science and Technology 46 (11), 6158-6166.

3. Abelleira-Pereira, J.M., Pérez-Elvira, S.I., Sánchez-Oneto, J., de la Cruz, R., Portela. J., Nebot, E. (2015). Enhancement of methane production in mesophilic anaerobic digestion of secondary sewage sludge by advanced thermal hydrolysis pretreatment. Water Research 71, 330-340.

4. Appels, L., Baeyens, J., Degrève, J., Dewil, R. (2008). Principles and potential of the anaerobic digestion of waste-activated sludge. Progress in Energy and Combustion Science 34, 755-781.

5. Appels, L., Degreve J., Van der Bruggen B., Van Impe J., Dewil R. (2010). Influence of low temperature thermal pre-treatment on sludge solubilisation, heavy metal release and anaerobic digestion. Bioresource Technology 101, 5743-5748.

6. Aqualogy [online]. Available at: http://www.aqualogy.net/esp/en/notabletechnologies/aqualysis [access 2016/08/03].

7. Baier, U., Schmidheiny, P. (1997). Enhanced anaerobic degradation of mechanically disintegrated biosolids. IAQW International Conference on waste water sludge, Cestochowa, Poland, Part 1, 106-112.

8. Barber, W.P.F. (2016). Thermal hydrolysis for sewage treatment: A critical review. Water Research 104, 53-71.

9. Batstone, D.J., Balthes, C., Barr, K. (2010). Model Assisted Startup of Anaerobic Digesters Fed with Thermally Hydrolysed Activated Sludge. Water Science and Technology 62(7), 1661-1666.

10. Battimelli, A., Millet, C., Delgenès, J.P., Moletta, R. (2003). Anaerobic digestion of waste activated sludge combined with ozone post-treatment and recycling. Water Science and Technology 48(4), 61-68. 
11. Baudez, J.C., Gupta, R.K., Eshtiaghi, N., Slatter, P. (2013). The viscoelastic behavior of raw and anaerobic digested sludge: strong similarities with softeglassy materials. Water Research 47, 173-180.

12. Biogest. CROWN-disintegration system [online]. Available at: http://www.biogest.com/ [access 01/08/16].

13. Bougrier, C., Delgenès, J.P., Carrère, H. (2007). Impacts of thermal pre-treatment on the semicontinuous anaerobic digestion of waste activated sludge. Biochemical Engineering Journal 34, 20-27.

14. Bougrier, C., Delgenès, J.P., Carrère, H. (2008). Effects of thermal treatments on five different waste activated sludge samples solubilisation, physical properties and anaerobic digestion. Chemical Engineering Journal 139 (2), 236-244.

15. Brown, S.L., Angle, J.S., Jacobs, W.L. (1998). Beneficial Co-Utilization of Agricultural, Municipal and Industrial by-Products. Netherlands: Springer Science+Business Media B.V.

16. Burgess, J.E., Pletschke, B.I. (2008). Hydrolytic enzymes in sewage sludge treatment: a minireview. Water S.A 34, 343-349.

17. Cambi [online]. Available at: http://www.cambi.com/Products/CambiTHP [access 2016/08/03].

18. Carballa, M., Omil, F., Lema, J.M. (2009). Influence of Different Pretreatments on Anaerobically Digested Sludge Characteristics: Suitability for Final Disposal. Water Air and Soil Pollution 199, 311-321.

19. Carrère, H., Dumas, C., Battimelli, A., Batstone, D., Delgenes, J., Steyer, J. \& Ferrer, I. (2010). Pretreatment methods to improve sludge anaerobic degradability: a review. Journal of hazardous materials 183, 1-15.

20. Carvajal, A., Peña, M., Pérez-Elvira, S.I. (2013). Autohydrolysis pretreatment of secondary sludge for anaerobic digestin. Biochemical Engineering Journal 75, 21-31.

21. Chiu, Y.C., Chang, C.N., Lin, L.G., Huang, S.J. (1997) Alkaline and ultrasonic pre-treatment of sludge before anaerobic digestion. Water Science and Technology 36(11), 155-162.

22. Cho, S.K., Ju, H.J., Lee, J.G., Kim, S.H. (2014). Alkaline-mechanical pretreatment process for enhanced anaerobic digestion of thickened waste activated sludge with a novel crushing device. Performance evaluation and economic analysis. Bioresource Technology 165, 183-190.

23. Chowdhury, N., Lalman, J.A., Seth, R., Ndegwa, P. (2007). Biohydrogen production by mesophilic anaerobic fermentation of glucose in the presence of linoleic acid. Journal of Environmental Enineering (ASCE) 133, 1145-1152.

24. Climent, M., Ferrer, I., Mar Baeza, M., Artola, A., Vázquez, F., Font, X. (2007). Effects of thermal and mechanical pretreatments of secondary sludge on biogas production under thermophilic conditions. Chemical Engineering Journal 133, 335-342.

25. Davidsson, A., Wawrzynczyk, J., Norrlow, O., Jansen, J.L. (2007). Strategies for enzyme dosing to enhance anaerobic digestion of sewage sludge. Journal of Residuals Science and Technology 4, 1-7. 
26. Dogan, I., Sanin, F.D. (2009). Alkaline solubilization and microwave irradiation as a combined sludge disintegration and minimization method. Water Research 43(8), 2139-2148.

27. Dohanyos, M., Zabranska, J., Jenicek, P. (1997). Enhancement of sludge anaerobic digestion by using of a special thickening centrifuge. Water Science and Technology 36 (11), 145-153.

28. Donoso-Bravo, A., Pérez-Elvira, S.I., Fdz-Polanco, F. (2010). Application of simplified models for anaerobic biodegradability tests. Evaluation of pre-treatment processes. Chemical Engineering Journal 160(2), 607-614.

29. Donoso-Bravo, A., Pérez-Elvira, S., Aymerich, E., Fdz-Polanco, F. (2011). Assessment of the influence of thermal pre-treatment time on the macromolecular composition and anaerobic biodegradability of sewage sludge. Bioresource Technology 102 (2), 660-666.

30. Dwyer, J., Starrenburg, D., Tait, S., Barr, K., Batstone, D.J., Lant, P. (2008). Decreasing activated sludge thermal hydrolysis temperature reduces product colour, without decreasing degradability. Water Research 42, 4699-4709.

31. Ecosolids [online]. Available at: https://www.environmental-expert.com/products/cellruptor$\underline{140806}$ [access 2016/08/10].

32. Eliquo Water and Energy [online]. Available at: http://www.eliquo-we.com/en/lysotherm.html [access 2016/08/03].

33. European Commission, (2010). Environmental, economic and social impacts of the use of sewage sludge on land. Final Report - Part I: Overview Report, Report by Milieu Ltd WRc and RPA for the European Commission, DG Environment under Study Contract DG ENV.G.4/ETU/2008/0076r.

34. Everret, J.G. (1974). The effect of $\mathrm{pH}$ on the heat treatment of sewage sludges. Water Research 8, 899-906.

35. Erden, G., Demir, O., Filibeli, A. (2010). Disintegration of biological sludge: effect of ozone oxidation and ultrasonic treatment on aerobic digestibility. Bioresource Technology 101, 80938098.

36. Fabregat, A., Bengoa, C., Font, J., Stueber, F. (2011). Reduction, Modification and Valorization of Sludge (Removals). IWA Publishing, UK.

37. Farno, E., Baudez, J.C., Parthasarathy, R., Eshtiaghi, N. (2014). Rheological characterization of thermally-treated anaerobic digested sludge: impact of temperature and thermal history. Water Research 56, 156-161.

38. Farno, E., Baudez, J.C., Parthasarathy, R., Eshtiaghi, N. (2015). Impact of temperature and duration of thermal treatment on different concentrations of anaerobic digested sludge: kinetic similarity of organic matter solubilisation and sludge rheology. Chemical Engineering Journal $273,534-542$.

39. Fernández-Polanco, D., Tatsumi, H. (2016). Optimum energy integration of thermal hydrolysis through pinch analysis. Renewable Energy 96, 1093-1102.

40. Ferrer, I., Ponsab, S., Vazquezc, F., Fontb, X. (2008). Increasing biogas production by thermal $\left(70{ }^{\circ} \mathrm{C}\right)$ sludge pre-treatment prior to thermophilic anaerobic digestion. Biochemical Engineering Journal 42, 186-192. 
41. Gavala, H.N., Yenal, U., Skiadas I.V., Westermann, P., Ahring, B.K. (2003) Mesophilic and thermophilic anaerobic digestion of primary and secondary sludge. Effect of pre-treatment at elevate temperature. Water Research 37, 4561-4572.

42. Ge, H., Jensen, P.D., Batstone, D.J. (2010). Pre-treatment mechanisms during thermophilicmesophilic temperature phased anaerobic digestion of primary sludge. Water Research 44, 123-130.

43. Giachino, N. (2011). Anaerobic digestion degradability of waste sludge after ultrasound and enzymic hydrolysis pretreatment. Master thesis. Department of Civil and Environmental Engineering, Polytechnic University of Milan, Italy.

44. Goel, R., Tokutomi, T., Yasui, H., Noike, T. (2003). Optimal process configuration for anaerobic digestion with ozonation. Water Science and Technology 48(4), 85-96.

45. Gu, Y., Li, Y., Li, X., Luo, P., Wang, H., Robinson, Z.P., Wang, X., Wu, J., Li, F. (2017). The feasibility and challenges of energy self-sufficient wastewater treatment plants. Applied Energy. Article in Press.

46. Gurieff, N., Bruus, J., Hoejsgaard, S., Boyd, J., Kline, M. (2011). The Next Generation of Thermal Hydrolysis: Exelys ${ }^{\mathrm{TM}}$ - A Continuous Process for Maximizing Biogas Production. Proceedings of the Water Environment Federation. Energy and Water (14), 1012-1025

47. Haarslev Industries [online]. Available at: http://www.haarslev.com/BusinessAreas/Environment-Division/Thermal-Treatment-of-Sludge/Hydrolysis [access 2016/08/03].

48. Hanjie, Z. (2010). Sludge Treatment to Increase Biogas Production. (Trita-LWR Degree Project). Royal Institute of Technology (KTH), Stockholm, Sweden.

49. Hasegawa, S., Shiota, N., Katsura, K., Akashi, A. (2000). Solubilization of organic sludge by thermophilic aerobic bacteria as a pretreatment for anaerobic digestion. Water Science and Technology 41, 163-169.

50. Haug, R.T., Stuckey, D.C., Gossett, J.M., Mccarty, P.L. (1978). Effect of thermal pretreatment on digestibility and dewaterability of organic sludges. Journal of the Water Pollution Control Federation, 73-85.

51. Higgins, M., Beightol, S., Mandahar, U., Xiao, S., Hung-Wei, L., Le, T., Mah, J., Pathak, B., Novak, J., Al-Omari, A., Murthy, S. (2015). Effect of thermal hydrolysis temperature on anaerobic digestion, dewatering and filtrate characteristics. In: Proceedings of WEFTEC 2015, New Orleans.

52. Hii, K., Baroutian, S., Parthasarathy, R., Gapes, D.J., Eshtiaghi, N. (2014). A review of wet air oxidation and Thermal Hydrolysis technologies in sludge treatment. Bioresource Technology $155,289-299$.

53. Hill, D. Michigan water environment association. Aerobic Digesters Anaerobic Digesters [online]. Available at: http://www.mi-wea.org/docs/Hill\%20-\%20Dueling\%20Digesters.pdf [access 13/07/16].

54. HoSt [online]. Available at: http://www.host.nl/en/biogas-plants/thermal-hydrolysis/ [access 2016/08/03]. 
55. Hu, B., Chen, S. (2007). Pretreatment of methanogenic granules for immobilized hydrogen fermentation. International Journal of Hydrogen Energy 32, 3266-3273.

56. Jean, D.S., Chang, B.V., Liao, G.S., Tsou, G.W., Lee, D.J. (2000). Reduction of microbial density level in sewage sludge through $\mathrm{pH}$ adjustment and ultrasonic treatment. Water Science and Technology 42(9), 97-102.

57. Jolis, D. (2008). High-solids anaerobic digestion of municipal sludge pretreated by thermal hydrolysis. Water Environment Research 80, 654-662.

58. Jolly, M., Gillard, J. (2009). The economics of advanced digestion. $14^{\text {th }}$ European Biosolids and Organic Resources Conference and Exhibition. United Kingdom.

59. Jung, K.W., Hwang, M.J., Cha, M.J., Ahn, K.H. (2015). Application and optimization of electric field-assisted ultrasonication for disintegration of waste activated sludge using response surface methodology with a Box-Behnken design. Ultrasonics Sonochemistry 22, 437-445.

60. Kaynak, G.E., Filibeli, A. (2008). Assessment of Fenton process as a minimization technique for biological sludge: Effects on anaerobic sludge bioprocessing. Journal of Residuals Science and Technology 5(3), 151-160.

61. Kepp, U., Machenbach, I., Weisz, N., Solheim, O.E. (2000). Enhanced stabilisation of sewage sludge through thermal hydrolysis - three years of experience with full scale plant. Water Science and Technology 42 (9), 89-96.

62. Khalid, A., Arshad, M., Anjum, M., Mahmood, T., Dawson, L. (2011). The anaerobic digestion of solid organic waste. Waste Management 31 (8), 1737-1744.

63. Kim, J., Park, C., Kim, T.H., Lee, M., Kim, S., Kim, S.W., Lee, J. (2003). Effects of various pretreatments for enhanced anaerobic digestion with waste activated sludge. Journal of Bioscience Bioengineering 95(3), 271-275.

64. Korres, N.E., O'Kiely, P., Benzie J.A.H., West, J.S. (2013). Bioenergy Production by Anaerobic digestion: Using agricultural biomass and organic waste. United Kingdom: Routledge.

65. Kuglarz, M., Karakashev, D., Angelidaki, I. (2013). Microwave and thermal pretreatment as methods for increasing the biogas potential of secondary sludge from municipal wastewater treatment plants. Bioresource Technology 134, 290-297.

66. Kunz, P., Wagner, S. (1994). Ergebnisse und Perspektiven aus Untersuchungen zur Klärschlammdesintegration, awt Abwassertechnik 44(2), 33-40.

67. Laurent, J., Casellas, M., Pons, M.N., Dagot, C. (2009). Flocs surface functionality assessment of sonicated activated sludge in relation with physico-chemical properties. Ultrasonics Sonochemistry 16, 488-494.

68. Li, Y.Y., Noike, T. (1992). Upgrading of anaerobic digestion of waste activated sludge by thermal pretreatment. Water Science and Technology 26, 857-866.

69. Liao, X., Li, H., Zhang, Y., Liu, C., Chen, Q. (2016). Accelerated high-solids anaerobic digestion of sewage sludge using low-temperature thermal pretreatment. International Biodeterioration \& Biodegradation 106, 141-149. 
70. Liu, X., Wang, W., Gao, X., Zhou, Y., Shen, R. (2012). Effect of thermal pretreatment on the physical and chemical properties of municipal biomass waste. Waste Management 32, 249255.

71. Ma, J., Duong, T.H., Smits, M., Verstraete, W., Carballe, M. (2011). Enhanced biomethanation of kitchen waste by different pre-treatments. Bioresource Technology 102, 592-599.

72. Mamais, D., Noutsopoulos, C., Dimopoulou, A., Stasinakis, A., Lekkas, T. (2015). Wastewater treatment process impact on energy savings and greenhouse gas emissions. Water Science and Technology 71, 303-308.

73. Mata-Alvarez, J., Dosta, J., Mace, S., Astals, S. (2011). Codigestion of solid wastes: a review of its uses and perspectives including modeling. Critical Reviews in Biotechnology 31(2), 99111.

74. Mayhew, M.E., Le, M.S., Ratcliff, R. (2002). A novel approach to pathogen reduction in biosolids: the enzymic hydrolyser. Water Science and Technology 46, 427-434.

75. Menco, L. (2012). CAMBI Thermal hydrolysis Sludge Treatment: Medium to large-scale application [online]. Available at: http://www.environmentindex.com/en/article/cambi-thermalhydrolysis-sludge-treatment-medium-to-large-scale-application-677.aspx [access 28/07/16].

76. Metcalf \& Eddy Inc., Tchobanoglous, G., Burton, F.L., Stensel, H.D. (2003). Wastewater Engineering: Treatment and Reuse. McGraw-Hill Companies Inc., New York.

77. Mills, N., Martinicca, H., Fountain, P., Shana, A., Ouki, S., Thorpe, R. (2013). Second generation thermal hydrolysis process. 18th European Biosolids and Organic Resources Conference, United Kingdom.

78. Morgan-Sagastume, F., Pratt, S., Karlsson, A., Cirne, D., Lant, P.,Werker, A. (2011). Production of volatile fatty acids by fermentation of waste activated sludge pre-treated in fullscale thermal hydrolysis plants. Bioresource Technology 102 (3), 3089-3097.

79. Mouneimne, A.H., Carrère, H., Bernet, N., Delgenès, J.P. (2003). Effect of saponification on the anaerobic digestion of solid fatty residues. Bioresource Technology 90(1), 89-94.

80. Mukherjee, S.R., Levine, A.D. (1992) Chemical solubilization of particulate organics as a pretreatment approach. Water Science and Technology, 26(9-11), 2289-2292.

81. Müller, J.A. (2001). Prospects and problems of sludge pre-treatment processes. Water Science and Technology 44(10), 121-128.

82. Müller, J.A., Winter, A., Strünkmann, G. (2004). Investigation and assessment of sludge pretreatment processes. Water Science and Techology 49(10), 97-104.

83. Neis, U., Nickel, K., Lunden, A. (2008). Improving anaerobic and aerobic degradation by ultrasonic disintegration of biomass. Journal of Environmental Science and Health. Part A, Toxic/hazardous Substances and Environmental Engineering 43 (13), 1541-1545.

84. Neyens, E., Baeyens, J. (2003). A review of thermal sludge pre-treatment processes to improve dewaterability. Journal of Hazardous Materials B98, 51-67. 
85. Neyens, E., Baeyens, J., Dewil, R. (2004). Advanced sludge treatment affects extracellular polymeric substances to improve activated sludge dewatering. Journal of Hazardous Materials $106(2), 83-92$.

86. Nges, I., Liu, J. (2009). Effects of anaerobic pretreatment on the degradation of dewatered sludge. Renewable Energy 34, 1795-1800.

87. Ngwenya, Z., Beightol, S., Ngone Oo, T., Vega, J., Pathak, B., Al-Omari, A., Zhu, K., Wadhawan, T., Murthy, S.N., Higgins, M.J. (2015). A stoichiometric a roach to control digester chemistry and ammonia inhibition in anaerobic digestion with thermal hydrolysis pretreatment: model development. In: Proceedings of WEF Residuals and Biosolids 2015. Water and Environment Federation, Washington DC.

88. Nielsen, H.B., Thygesen, A., Thomsen, A.B., Schmidt, J.E. (2011). Anaerobic digestion of waste activated sludge - comparison of thermal pre-treatments with thermal inter-stage treatments. Journal of Chemical Technology and Biotechnology 86, 238-245.

89. Onyeche, T.I. (2007). Economic benefits of low pressure sludge homogenization for wastewater treatment plants. IWA specialist conferences. Moving Forward Wastewater Biosolids Sustainability, Canada, 2007.

90. Oosterhuis, M., Ringoot, D., Hendriks, A., Roeleveld, P. (2014). Thermal hydrolysis of waste activated sludge at Hengelo Wastewater Treatment Plant, The Netherlands. Water Science and Technology 70(1), 1-7.

91. Ortega-Martinez, E., Sapkaite, I., Fdz-Polanco, F., Donoso-Bravo, A. (2016). From pretreatment toward inter-treatment. Getting some clues from sewage sludge biomethanation. Bioresource Technology, 212, $227-235$.

92. Panepinto, D., Fiore, S., Zappone, M., Genon, G., Meucci, L. (2016). Evaluation of the energy efficiency of a large wastewater treatment plant in Italy. Applied Energy 161, 404-411.

93. Panter, K., Kleiven, H. (2005). Ten years experience of full scale thermal hydrolysis projects. 10th European Biosolids and Biowastes Conference, United Kingdom.

94. Penaud, V., Delgenes, J.P., Moletta, R. (2000). Influence of thermochemical pretreatment conditions on solubilization and anaerobic biodegradability of a microbial biomass. Environmental Technology 21, 87-96.

95. Pérez-Elvira, S.I., Fdz-Polanco, M., Fdz-Polanco, F. (2010). Increasing the performance of anaerobic digestión: Pilot scale experimental study for thermal hydrolysis of mixed sludge. Frontiers of Environmental Science \& Engineering 4(2), 135-141.

96. Perez-Elvira, S.I., Fdz-Polanco, F. (2012). Continuous thermal hydrolysis and anaerobic digestion of sludge. Energy integration study. Water Science and Technology 65, 1839-1846.

97. Pérez-Elvira, S. I.; Sapkaite, I.; Fernández-Polanco, F. (2014). Evaluation of thermal steamexplosion key operation factors to optimize biogas production from biological sludge. Water Science and Technology 72.6, 937-945.

98. Perrault, A., Thorpe, R.B., Cataldi, A., Mills, N., Barua, R. (2015). Steam explosion of sludge in the THP process. In: Proceedings of Sludgetech Conference, Guilford, Surry, UK. 
99. Pilli, S., More, T., Yan, S., Tyagi, R.D., Surampalli, R.Y. (2015). Anaerobic digestion of thermal pre-treated sludge at different solids concentrations - Computation of mass-energy balance and greenhouse emissions. Journal of Environmental Management 157, 250-261.

100. Pinnekamp, J. (1989). Effects of thermal pretreatment of sewage sludge on anaerobic digestion. Water Science and Technology 21, 97-108.

101. Pook, M., Mills, N., Heitmann, M., Panter, K., Walley, P. (2013). Exploring the upper limits of thermal hydrolysis at Chertsey STW. In: Proceedings of Aqua-enviro $18^{\text {th }}$ European Biosolids and Organic Residuals Conference and Exhibition, Manchester, UK.

102. Prorot, A., Laurent, J., Dagot, C., Leprat, P. (2011). Sludge disintegration during heat treatment at low temperature: A better understanding of involved mechanisms with a multiparametric approach. Biochemical Engineering Journal 54, 178-184.

103. Rivero, J.A.C., Madhavan, N., Suidan, M.T., Ginestet, P., Audic, J.M. (2006). Enhancement of anaerobic digestion of excess municipal sludge with thermal and/or oxidative treatment. Journal of Environmental Engineering ASCE 132(6), 638-644.

104. Romero, P., Coello, M.D., Quiroga, J.M., Aragon, C.A. (2013). Overview of sewage sludge minimisation: techniques based on cell lysis-cryptic growth. Desalination and Water Treatment 51, 5918-5933.

105. Ruffino, B., Campo, G., Genon, G., Lorenzi, E., Novarino, D., Scibilia, G., Zanetti, M. (2015). Improvement of anaerobic digestion of sewage sludge in a wastewater treatment plant by means of mechanical and thermal pre-treatments: Performance, energy and economical assessment. Bioresource Technology 175, 298-308.

106. Salsabil, M.R., Laurent, J., Casellas, M., Dagot, C. (2010). Techno-economic evaluation of thermal treatment, ozonation and sonication for the reduction of wastewater biomass volume before aerobic or anaerobic digestion. Journal of Hazardous Materials 174, 323-333.

107. Serrano, A., Siles, J.A., Gutiérrez, M.C., Martín, M.A. (2015) Improvement of the biomethanization of sewage sludge by thermal pre-treatment and co-digestion with strawberry extrudate. Journal of Cleaner Production 90, 25-33.

108. Shana, A. D., Ouki, S., Asaadi, M., Pearce, P. (2011). Application of an innovative process for improving mesophilic anaerobic digestion of sewage sludge. 16th European Biosolids and Organic Resources Conference, Scotland.

109. Shana, A.D., Ouki, S., Asaadi, M., Pearce, P. (2012) A study of the impact of an innovative intermediate thermal hydrolysis process on the performance of anaerobic sewage sludge digestion process. IWA World Congress on Water, Climate and Energy, Ireland.

110. Shana, A.D., Ouki, S., Asaadi, M., Pearce, P., Mancini, G. (2013). The impact of intermediate thermal hydrolysis on the degradation kinetics of carbohydrates in sewage sludge. Bioresource Technology 137, $239-244$.

111. Stephenson, R.J., Laliberte, S., Hoy, P.M., Britch, D. (2007). Full scale and laboratory scale results from the trial of microsludge at the joint water pollution control plant at Los Angeles County. IWA Specialist Conferences. Moving Forward Wastewater Biosolids Sustainability, Canada. 
112. Steve, W., Panter, K. (2002). Operating experience of Aberdeen Cambi thermal hydrolysis plant. CIWEM/Aqua Enviro 7th European Biosolids and Organic Residuals Conference, United Kingdom.

113. Stickland, A.D. (2015). Compressional rheology: a tool for understanding compressibility effects in sludge dewatering. Water Research 82, 37-46.

114. Strong, P.J., McDonald, B., Gapes, D.J. (2011). Combined thermochemical and fermentative destruction of municipal biosolids: a comparison between thermal hydrolysis and wet oxidative pre-treatment. Bioresource Technology 102 (9), 5520-5527.

115. Stuckey, D.C., McCarty, P.L. (1984). The effect of thermal pretreatment on the anaerobic biodegradability and toxicity of waste activated sludge. Water Research 18(11),1343-1353.

116. Suárez-Iglesias, O., Urrea, J.L., Oulego, P., Collado, S., Díaz, M. (2017). Valuable compounds from sewage sludge by termal hydrolysis and wet oxidation. A review. Science of the Total Environment (584-585), 921-934.

117. Sustec [online]. Available at: http://sustec.nl/[access 2016/08/03].

118. Tech4plus [online]. Available at: http://tech4plus.com/technology/ [access 2016/08/03].

119. Thiruvenkadam, S. (2011). Evaluation of Cellruptor pre-treatment on biogas yield from various substrates. Masther thesis. Department of Biotechnology, Royal Institute of Technology, Stockholm, Sweden.

120. Turovskiy, I.S., Mathai, P.K. (2006). Wastewater sludge processing. John Wiley \& Sons, Inc., Hoboken (New Jersey).

121. Valo, A., Carrère, H., Delgenès, J. (2004). Thermal, chemical and thermo-chemical pretreatment of waste activated sludge for anaerobic digestion. Journal of Chemical Technology and Biotechnology

122. 79, 1197-1203.

123. Veolia Water [online]. Available at:

http://technomaps.veoliawatertechnologies.com/processes/lib/municipal/3472-

150612_Thermal_Hydrolysis_EN_2016.pdf [access 2016/08/03].

124. Veolia Water, Biothelys [online]. Available at:

http://technomaps.veoliawatertechnologies.com/biothelys/en/ [access 2016/08/03].

125. Veolia Water, Exelys [online]. Available at:

http://technomaps.veoliawatertechnologies.com/exelys/en/ [access 2016/08/03].

126. Vivalin, V.A., Loksina, L.Ya., Jokela, J.P.Y., Rintala, J.A. (2004). Modelling solid waste decomposition. Bioresource Technology 94, 69-81.

127. Wang, Q., Noguchi, C., Hara, Y., Sharon. C., Kakimoto, K., Kato, Y. (1997). Studies on anaerobic digestion mechanism: influence of pretreatment temperature on biodegradation of waste activated sludge. Environmental Technology 18, 999-1008.

128. Weemaes, M., Grootaerd, H., Simoens, F., Verstraete, W. (2000). Anaerobic digestion of ozonized biosolids. Water Research 34(8), 2330-2336. 
129. Weise, Th.H.G.G., Jung, M. (1998). Klärschlammbehandlung mit der Hochleistungspulstechnik. Veröffentlichung des Institutts für Siedlungswasserwirtschaft der TU Braunschweig, Heft 61, 75-82.

130. Weise, Th.H.G.G., Jung, M. (2001). Sludge disintegration by electrical shockwaves. International Conference on Pulsed Power Applications. Gelsenkirchen, March 2001.

131. Wilson, C.A., Murthy, S.M., Fang, Y., Novak, J.T. (2008). The effect of temperature on the performance and stability of thermophilic anaerobic digestion. Water Science and Technology 57 (2), 297-304.

132. Wilson, C.A., Novak, J.T. (2009). Hydrolysis of macromolecular components of primary and secondary wastewater sludge by thermal hydrolytic pretreatment. Water Research 43, 44894498.

133. Wilson, C.A., Tanneru, C.T., Banjade, S., Murthy, S.N., Novak, J.T. (2011). Anaerobic digestion of raw and thermally hydrolyzed wastewater solids under various operational conditions. Water Environmental Research 83, 815-825.

134. Winter, A. (2002). Minimisation of costs by using disintegration at a full-scale anaerobic digestion plant. Waterer Science and Technology 46(4-5), 405-412.

135. World Bank Group. Introduction to Wastewater Treatment Processes [online]. Available at: http://water.worldbank.org/shw-resource-guide/infrastructure/menu-technicaloptions/wastewater-treatment [access 13/07/16].

136. Woodford, C. (2009). Autoclaves [online]. Available at:

http://www.explainthatstuff.com/autoclaves.html [access 27/07/2016].

137. Xie, R., Xing, Y., Ghani, Y.A., Ooi, K.E., Ng, S.W. (2007). Full-scale demonstration of an ultrasonic disintegration technology in enhancing anaerobic digestion of mixed primary and thickened secondary sewage sludge. Journal of Environmental Engineering and Science 6(5), 533-541.

138. Xu, C.C., Lancaster, J. (2009). Treatment of Secondary Sludge for Energy Recovery. Energy recovery, Nova Science Publishers Inc., New York, pp. 187-211.

139. Xu, G., Chen, S., Shi, J., Wang, S., Zhu, G. (2010). Combination treatment of ultrasound and ozone for improving solubilisation and anaerobic biodegradability of waste activated sludge. Journal of Hazardous Materials 180,340-346.

140. Xue, Y., Liu, H., Chen, S., Dichtl, N., Dai, X., Li, N. (2015). Effects of thermal hydrolysis on organic matter solubilisation and anaerobic digestion of high solid sludge. Chemical Engineering Journal 264, 174-180.

141. Yan, S., Miyanaga, K., Xing, X.H., Tanji, Y. (2008). Succession of bacterial community and enzymatic activities of activated sludge by heat-treatment for reduction of excess sludge. Biochemical Engineering Journal 39, 598-603.

142. Yeom, I.T., Lee, K.R., Lee, Y.H., Ahn, K.H., Lee, S.H. (2002). Effects of ozone treatment on the biodegradability of sludge from municipal wastewater treatment plants. Water Science and Technology, 46 (4-5), 421-425. 
143. Zabranska, J., Dohanyos, M., Jenicek, P., Kutil, J. (2006) Disintegration of excess activated sludge - evaluation and experience of full-scale applications. Water Science and Technology 53(12), 229-236.

144. Zhang, L., Zhang, Y., Zhang, Q., Verpoort, F., Cheng, W., Caoi, 1., Li, M. (2014). Sludge gas production capabilities under various operational conditions of the sludge thermal hydrolysis pretreatment process. Journal of the Energy Institute 87, 121-126.

145. Zheng, Y.Z., Lin, H.M., Tsao, G.T. (1998). Pretreatment for cellulose hydrolysis by carbon dioxide explosion. Biotechnology Progress 14, 890-896 
CHAPTER 3

Materials and
methods 

A graphical scheme of the materials and equipment used to perform the research is below enclosed and described.
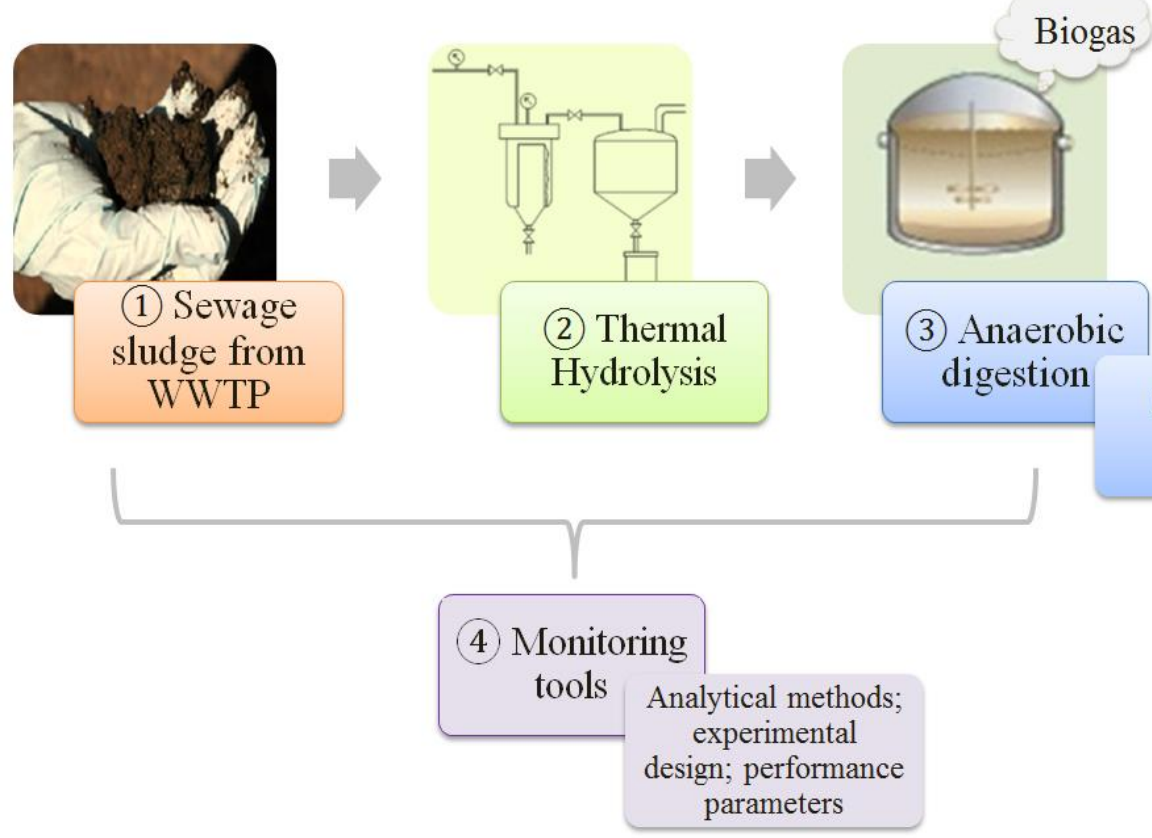

BMP tests; Modelling

\subsection{Substrates}

All the study was performed with concentrated waste activated sludge. The selection of this type of substrate was based on previous results obtained by the research group (Pérez-Elvira et al. 2010; Pérez-Elvira and Fdz-Polanco 2012). These studies exhibited that primary sludge biodegradability (naturally better than for secondary sludge) does not improve substantially after a pre-treatment, and that sludge concentration plays a key role for the process economics, although presenting a technical limit. For anaerobic digestion, digested sludge was sampled as inoculum.

An average characterization of both is presented in Table 8:

Table 8. Substrates characteristics.

\begin{tabular}{llll}
\hline & TS $(\mathrm{g} / \mathrm{kg})$ & $\mathrm{VS}(\mathrm{g} / \mathrm{kg})$ & DQO $_{\mathbf{T}}(\mathrm{g} / \mathrm{L})$ \\
\hline Waste activated sludge & 137.6 & 108.9 & 164.0 \\
Digested sludge/Inoculum & 21.2 & 11.7 & 15.8 \\
\hline
\end{tabular}

The sludge was sampled from the waste water treatment plant (WWTP) of Valladolid, Spain. Waste activated sludge came from the settling operation after the secondary clarifier, and the inoculum was taken from the anaerobic digester, treating mixed sludge. 


\subsection{Pre-treatment unit}

The main operating conditions or factors to decide a thermal process were:

* Temperature / Pressure: The sludge was "cooked" under vapor-liquid equilibrium, at the desired temperature. The heating was achieved with direct steam injection from a steam boiler.

* Time: Duration of the "cooking" under the pressure.

* Decompression: The release of the operating pressure in the reactor can be performed slowly (no flash occurs) or fast (steam explosion effect). According to previous research in the group (Donoso-Bravo et al. 2011), sudden decompression has a crucial positive impact on thermal pretreatment process.

Two thermal hydrolysis pre-treatment equipments (Figure 24) were operated in batch to perform the experiments. A brief description of them is enclosed:

Thermal hydrolysis laboratory-scale: The plant consists of a $1.5 \mathrm{~L}$ total volume hydrolysis reactor heated with the live steam from a steam boiler, and connected to an atmospheric flash tank (6 L) by a decompression valve that opens in a steam-explosion effect (sudden decompression). The system is equipped with outlet pipes for steam injection and hydrolysed sludge flushing, with manual valves that control the steam entrance from boiler and the sludge exit from the reactor to the flash tank. The operation is batch, and the pressure, temperature and time of the thermal hydrolysis are measured offline by a manometer, a temperature sensor and a chronometer, respectively.

Thermal hydrolysis pilot-scale: This pilot plant is bigger compared to the laboratory unit, and automatically controlled instead of manual. This unit consists of a $20 \mathrm{~L}$ total volume hydrolysis reactor heated with the live steam from a steam boiler, and connected to an atmospheric flash tank (100 L) by a decompression valve. The operation is batch, and automatically controlled by fixing both temperature and hydrolysis time. Pre-treatment time is controlled by software that controls the entrance of steam in function of pressure inside the reactor. Pressure and temperature values are measured by sensors that are inside of the reactor and automatically registered by software. When the process is finished decompression valve opens automatically in a steamexplosion effect and the hydrolysed sludge flows to the flash tank. 

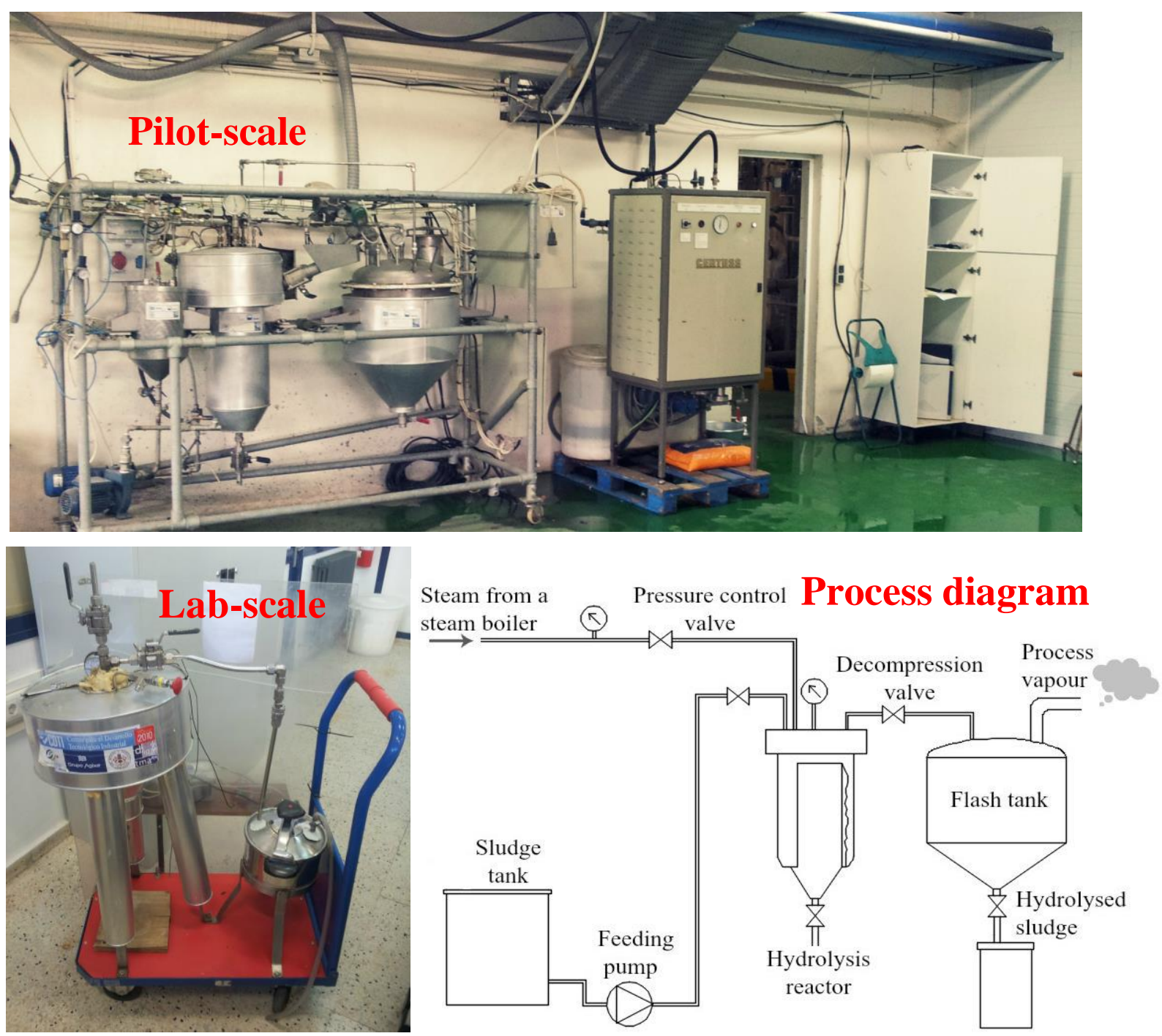

Figure 24. Thermal hydrolysis pilot-scale, lab-scale and process diagram.

\subsection{Anaerobic digestion}

\subsubsection{Biochemical methane potential tests}

Biochemical methane potential (BMP) tests are the most appropriate experimental methodology to evaluate and compare the kinetics and methane potential during anaerobic degradation of different substrates or of a specific substrate under different conditions. Although results from continuous digesters are more realistic, in some situations it is not viable, such as the comparison of the wide number of alternatives explored in this thesis.

The BMP methodology used in this research followed an internal protocol based on standardized assays for research purposes (Angelidaki et al. 2009), with the following criteria:

$>$ The assays were always performed by triplicate.

Serum bottles of $160 \mathrm{~mL}, 300 \mathrm{~mL}$ and $2 \mathrm{~L}$ were used. 
Substrate to inoculum ratio (SIR) of $0.5 \mathrm{~g} / \mathrm{g}$ on volatile solids basis was applied.

The anaerobic inoculum was WWTP mesophilic digested sludge and was pre-incubated for 2 days at $35^{\circ} \mathrm{C}$ in a thermostatic chamber prior to use in order to activate the microorganisms and to deplete most of the residual organic matter.

In the tests micro and macro nutrients $(1 \mathrm{ml} / \mathrm{L}$ of each) were used for optimal function of anaerobic microorganisms. Moreover, $\mathrm{NaHCO}_{3}(5 \mathrm{~g} / \mathrm{L})$ and $\mathrm{Na}_{2} \mathrm{~S} \cdot 9 \mathrm{H}_{2} \mathrm{O}$ small stone were added to provide a buffer capacity and avoid aerobic conditions, respectively.

Reference tests containing only anaerobic inoculum were also prepared to determine the endogenous methane production of the inoculum.

The assays were closed with rubber stoppers, sealed with aluminum caps and purged with helium in order to displace the air.

Serum bottles were incubated in a thermostatic chamber at $35^{\circ} \mathrm{C}$ (mesophilic conditions) in an orbital $(150 \mathrm{rpm} / \mathrm{min})$ or rotary $(5 \mathrm{rpm} / \mathrm{min})$ shaker.

$>$ The pressure in the headspace of the BMP bottles was periodically measured with a pressure sensor PN 5007 (IFM, Germany), and biogas composition was determined using a gas chromatograph (Varian CP-3800, USA) injecting biogas sample volume of $100 \mu \mathrm{L}$ with a gastight Hamilton syringe.

After each measurement assay vessels were depressurized until 10mbars (not less) to avoid the intake of air.

$>$ The tests were finished when the daily methane production was less than $1 \%$ of total $\mathrm{CH} 4$ accumulation.

The main equipment (serum bottles, orbital and rotary shakers, pressure sensor, gas-tight Hamilton syringe and gas chromatograph) used in BMP tests are presented in Figure 25. 

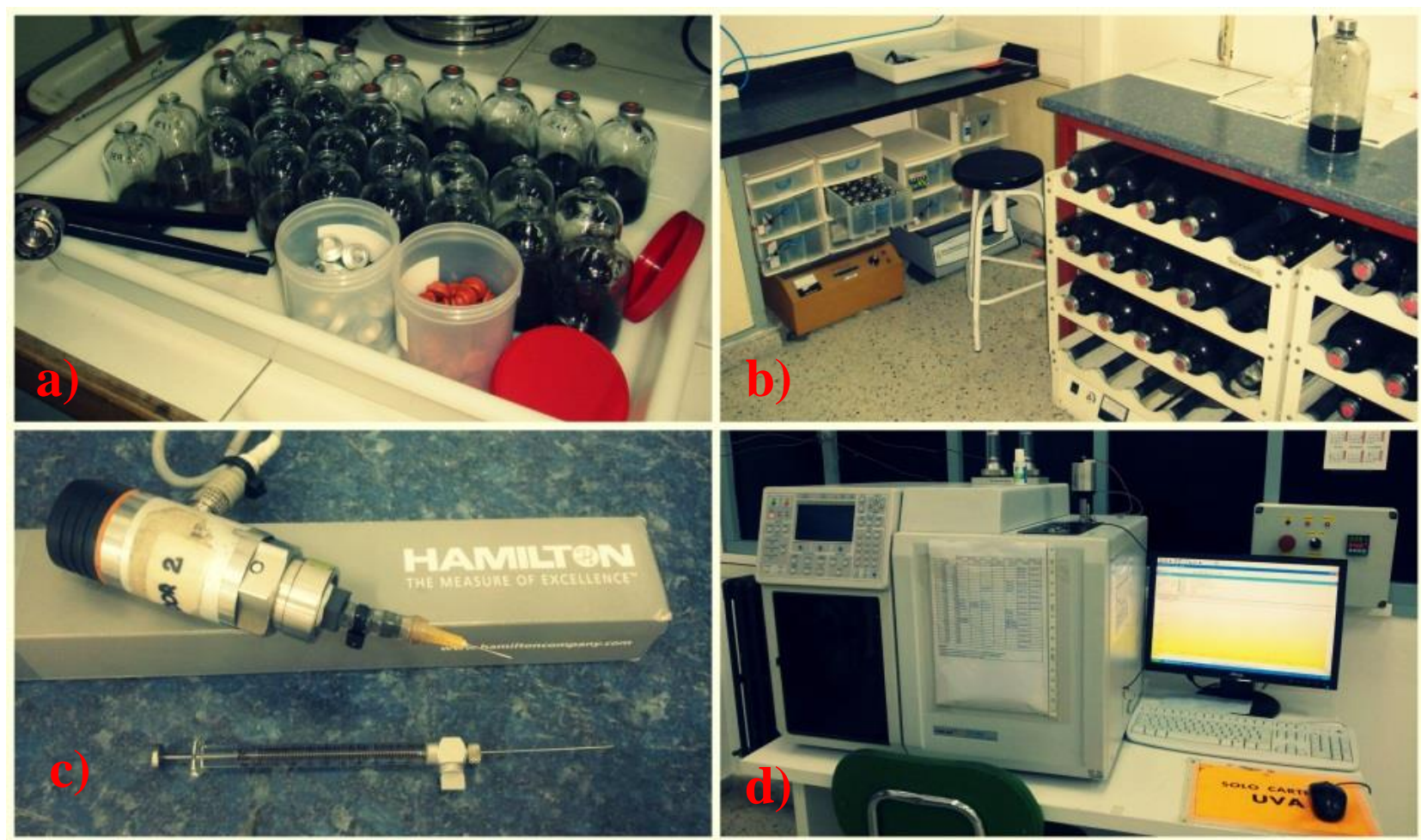

Figure 25. The main equipment used in BMP tests: Serrum bottles (a), shakers (b), pressure sensor and gas-tight syringe (c), gas chromatograph (d).

\subsubsection{Modelling BMP tests}

In Chapters 4 and 6 four models were considered to fine-tune the experimental data from BMP tests to theoretical equations in order to estimate kinetic parameters with a certain degree of confidence. Based on similar studies for solid wastes (Cano Herranz 2014), the models considered were (see Table 9): First Order equation (FO), Modified Gompertz equation (MG), Transference Function (TF), and Logistic Function (LF).

Table 9. Model equations.

\begin{tabular}{lcc}
\hline Model & Equation & References \\
\hline FO & $B=P \times\left[1-\exp \left(-\mu_{\text {max }} \cdot t\right)\right]$ & $\begin{array}{c}\text { Pavlostathis and } \\
\text { Giraldo-Gomez } \\
(1991)\end{array}$ \\
MG & $B=P \times \exp \left\{-\exp \left[\frac{R_{m} \times e}{P}(\lambda-t)+1\right]\right\}$ & $\begin{array}{c}\text { Lay et al. (1997); } \\
\text { Nopharatana et al. } \\
(2007)\end{array}$ \\
TF & $B=P \times\left[1-\exp \left(\frac{-R_{m}(t-\lambda)}{P}\right)\right]$ & $\begin{array}{c}\text { Donoso-Bravo et al. } \\
(2011) ; \\
\text { Redzwan \& Banks } \\
(2004)\end{array}$ \\
LF & $B=\frac{1}{P}\left[\begin{array}{c}\text { Donoso-Bravo et al. } \\
(2010) ; \\
\text { Altas (2009) }\end{array}\right.$ \\
\hline
\end{tabular}


Despite differing mathematically from each other, the four models have common features: a kinetic parameter $\left(\mathrm{R}_{\mathrm{m}}\right.$ or $\left.\mu_{\max }\right)$ which indicates the maximum slope of the curve $\left(\mathrm{mL} \mathrm{CH}_{4} / \mathrm{gVS} / \mathrm{d}\right)$, a maximum biogas production parameter $(\mathrm{P})$ expressed as $\mathrm{mL} \mathrm{CH}_{4} / \mathrm{gVS}$, and a lag-phase parameter $(\lambda)$, in days. $\mathrm{B}$ is the calculated methane production $\left(\mathrm{mL} \mathrm{CH}_{4} / \mathrm{gVS}\right)$ for each time $\mathrm{t}$. The correlation factor $\left(\mathrm{R}^{2}\right)$ was also calculated to assess the accuracy of each model with respect to the experimental data.

\subsection{Monitoring tools}

\subsubsection{Analytical methods}

Substrates characterization was performed in the University of Valladolid, following an internal protocol based on Standard methods (APHA, 2005) to determine the next parameters: total and volatile solids, soluble and total chemical oxygen demand.

Next, a brief description of the main parameters determination methodology is summarized:

Total and volatile solids (TS, VS): both were determined by gravimetric method and expressed as $\mathrm{g} / \mathrm{kg}$. Total solids were determined from the weight loss that $25-50 \mathrm{~g}$ of sample suffers after a drying process at $105^{\circ} \mathrm{C}$ for 24 hours. The sample is then subjected to a calcination process at $550^{\circ} \mathrm{C}$ until dry weight becomes constant (about 2 hours) to determine volatile solids.

Chemical oxygen demand (COD): the organic matter of the sample is oxidised with $\mathrm{K}_{2} \mathrm{Cr}_{2} \mathrm{O}_{7}$ (oxidiser) in an acidic medium $\left(\mathrm{H}_{2} \mathrm{SO}_{4}\right)$ with the addition of $\mathrm{Ag}_{2} \mathrm{SO}_{4}$ (catalyser) and $\mathrm{HgSO}_{4}$ (complexer agent of chlorides) at $105^{\circ} \mathrm{C}$ for 2 hours. After the digestion, the excess of oxidiser is quantified with Mohr salt $\left.\left(\mathrm{Fe}\left(\left(\mathrm{NH}_{4}\right)_{2} \mathrm{SO}_{4}\right)_{2} * 6 \mathrm{H}_{2} \mathrm{O}\right)\right)$ by titration with ferroin as indicator. For the soluble COD determination the sample was previously centrifuged at $5000 \mathrm{rpm}$ for 10 minutes and filtrated using a $47 \mathrm{~mm}$ hydrophilic Glass Fiber filter with a $0.7 \mu \mathrm{m}$ pore size (AP40).

\subsubsection{Performance parameters}

Severity factor - Used as a reference parameter to unify temperature and time pre-treatment conditions in a single severity indicator. As explained by Ferreira et al. (2014) this parameter is widely accepted for steam explosion process despite is does not take into account the flash decompression or any other factor involved. This parameter was calculated by Equation [1]:

$$
\log R_{0}=\log \left(t \cdot \exp \left(\frac{T-100}{14.75}\right)\right)
$$

Where $t$ is the time of reaction ( $\mathrm{min})$ and $T$ is the temperature $\left({ }^{\circ} \mathrm{C}\right)$. 
Solubilisation factor - This factor was determined after the pre-treatment process to quantify the increase of soluble matter which takes place for each treatment condition (Equation [2]). It is worth mentioning that this parameter was calculated with respect to the particulate fraction of the chemical oxygen demand (which is the potentially hydrolysable fraction during the pretreatment) in contrast to most of the references that express this parameter with respect to the total COD.

$$
\% S F=\frac{(\mathrm{SCOD} / \mathrm{TCOD})_{T H}-(S C O D / T C O D)_{0}}{((T C O D-S C O D) / T C O D)_{0}} \times 100
$$

where $T C O D_{0}$ and $S C O D_{0}$ are the total and soluble concentrations in the raw not pre-treated sludge, and $T C O D_{T H}$ and $S C O D_{T H}$ are the total and soluble concentrations after pre-treatment.

Methane potential - This one is the key parameter to quantify the methane production obtained in the BMP tests, and is expressed per unit of substrate fed (Equation [3]):

$$
\mathrm{CH}_{4}=\frac{m L C H_{4}}{g V S_{\text {fed }}} \mathrm{mL} \mathrm{CH} 4 / \mathrm{gS}_{\text {fed, }} \text {, at standard conditions }\left(0^{\circ} \mathrm{C}, 1 \mathrm{~atm}\right)
$$

Biodegradability - Calculated as the ratio of the experimental ( $\mathrm{mL} \mathrm{CH}_{4} / \mathrm{gCOD}$ ) to the theoretical methane production $\left(350 \mathrm{mLCH}_{4} / \mathrm{gCOD}_{\text {removed }}\right)$. This parameter was calculated by the Equation [4]:

$$
\% B D=\frac{m L C H_{4} / g V S_{f e d}}{\left(350 m L C H_{4} / g T C O D_{r e m}\right) \cdot(g T C O D / g V S)} \times 100
$$

Degradation factor - This factor is determined after anaerobic digestion of thermally pre-treated sludge, with the aim to quantify the increase of methane production from the solubilized particulate fraction of the COD (Equation [5]):

$$
\% D F=\frac{\left(\mathrm{mLCH}_{4} / \mathrm{gTCOD}\right)_{\mathrm{TH}}-(\mathrm{mLCH} / \mathrm{gTCOD})_{0}}{(\mathrm{mLCH} / \mathrm{gTCOD})_{0} \cdot((\mathrm{TCOD}-\mathrm{SCOD}) / \mathrm{TCOD})_{0}} \times 100
$$

\subsubsection{Experimental design and statistical analysis}

In Chapter 5, Response Surface Methodology (RSM) with Box-Behnken experimental Design (BBD) (Benito-Roman et al. 2013; Jung et al. 2015; Sarat Chandra et al. 2014) was used in order to 
statistically and mathematically compare the results (performance parameters described in section 3.4.2), and to determine the optimal thermal hydrolysis conditions and the effects of their interactions on the overall process efficiency. RSM is a collection of mathematical and statistical techniques that are useful for the modelling and analysis of problems in which a response of interest is influenced by several variables and the final objective is to optimize this response. The BBD was used because comparing this design and other response surface designs (central composite, Doehlert matrix and three-level full factorial design) the Box-Behnken design has demonstrated to be slightly more efficient than the central composite design but much more efficient than the three-level full factorial designs.

The relationship between the variables and responses was correlated with a quadratic polynomial Equation [6] that was fitted as follows:

$$
Y=\beta_{0}+\sum_{j=1}^{k} \beta_{j} X_{j}+\sum_{j=1}^{k} \beta_{j j} X_{j}^{2}+\sum_{i=1}^{k} \sum_{j=1}^{k} \beta_{i j} X_{i} X_{j}
$$

where $\mathrm{Y}$ is the estimated response variable to be optimized, $\mathrm{Xj}$ are the variables evaluated, $\beta_{0}$ is the constant, $\beta_{\mathrm{j}}$ is the linear coefficient, $\beta_{\mathrm{jj}}$ is a quadratic coefficient and $\beta_{\mathrm{ij}}$ is the interactive coefficient.

An analysis of variance (ANOVA) with 95\% confidence level was done for response variable in order to test the model significance and suitability. The significance of each coefficient was determined using the F-value test, at a 95\% confidence level.

\subsection{References}

1. Altas, L. (2009). Inhibitory effect of heavy metals on methane producing anaerobic granular sludge. Journal of Hazardous Materials 162 (2-3), 1551-1556.

2. Angelidaki, I., Alves, M., Bolzonella, D., Borzacconi, L., Campos, J.L., Guwy, A.J., Kalyuzhnyi, S., Jenicek, P., Van Lier, J.B. (2009). Defining the biomethane potential (BMP) of solid organic wastes and energy crops: a proposed protocol for batch assays. Water Science and Technology 59 (5), 927-934.

3. APHA, AWWA, WPCP. (2005). Standard Methods for the Examination of Water and Wastewater, 21th ed. Washington DC.

4. Benito-Roman, O., Alonso, E., Cocero, M.J. (2013). Ultrasound-assisted extraction of $\beta$ glucans from barley. LWT - Food Science and Technology 50, 57-63.

5. Cano Herranz, R. (2014). Pretreatment Technologies to Enhance Solid Wastes Anaerobic Digestion. PhD thesis, Department of Chemical Engineering and Environmental Technology, University of Valladolid, Spain. 
6. Donoso-Bravo, A., Pérez-Elvira, S.I., Fdz-Polanco, F. (2010). Application of simplified models for anaerobic biodegradability tests. Evaluation of pre-treatment processes. Chemical Engineering Journal 160 (2), 607-614.

7. Donoso-Bravo, A., Pérez-Elvira, S.I., Aymerich, E., Fdz-Polanco, F. (2011). Assessment of the influence of thermal pretreatment time on the macromolecular composition and anaerobic biodegradability of sewage sludge. Bioresource technology 102, 660-666.

8. Ferreira, L.C., Souza, T.S.O., Fdz-Polanco, F., Pérez-Elvira, S.I. (2014). Thermal steam explosion pretreatment to enhance anaerobic biodegradability of the solid fraction of pig manure. Bioresource Technology 152, 393-398.

9. Jung, K.W., Hwang, M.J., Cha, M.J., Ahn, K.H. (2015). Application and optimization of electric field-assisted ultrasonication for disintegration of waste activated sludge using response surface methodology with a Box-Behnken design. Ultrasonics Sonochemistry 22, 437-445.

10. Lay, J.J., Li, Y.Y., Noike, T. (1997). Influences of pH and moisture content on the methane production in high-solids sludge digestion. Water Research 31 (6), 1518-1524.

11. Nopharatana, A., Pullammanappallil, P.C., Clarke, W.P. (2007). Kinetics and dynamic modelling of batch anaerobic digestion of municipal solid waste in a stirred reactor. Waste Management 27 (5), 595-603.

12. Pavlostathis, S.G., Giraldo-Gomez, E. (1991). Kinetics of anaerobic treatment: A critical review. Critical Reviews in Environmental Control 21 (5-6), 411-490.

13. Pérez-Elvira, S.I., Fdz-Polanco, M., Fdz-Polanco, F. (2010). Increasing the performance of anaerobic digestión: Pilot scale experimental study for thermal hydrolysis of mixed sludge. Frontiers of Environmental Science \& Engineering 4(2), 135-141.

14. Perez-Elvira, S.I., Fdz-Polanco, F. (2012). Continuous thermal hydrolysis and anaerobic digestion of sludge. Energy integration study. Water Science and Technology 65, 1839-1846.

15. Redzwan, G., Banks, C. (2004). The use of a specific function to estimate maximum methane production in a batch-fed anaerobic reactor. Journal of Chemical Technology and Biotechnology 79 (10), 1174-1178.

16. Sarat Chandra, T., Suvidha, G., Mukherji, S., Chauhan, V.S., Vidyashankar, S., Krishnamurthi, K., Sarada, R., Mudliar, S.N. (2014). Statistical optimization of thermal pretreatment conditions for enhanced biomethane production from defatted algal biomass. Bioresourse Technology 162, 157-165. 


\section{CHAPTER 4}

Pérez-Elvira S.I, Sapkaite I, Fdz-Polanco F (2015)

Water Science \& Technology 72 (6), 937-945

\section{Evaluation of thermal steam- explosion key operation factors to optimize biogas production from biological sludge}





\title{
Evaluation of thermal steam-explosion key operation factors to optimize biogas production from biological sludge
}

\author{
S. I. Pérez-Elvira, I. Sapkaite and F. Fdz-Polanco
}

\begin{abstract}
Thermal steam-explosion is the most extended hydrolysis pretreatment to enhance anaerobic digestion of sludge. Thermal hydrolysis key parameters are temperature $(T)$ and time $(t)$, and the generally accepted values reported from full-scale information are: $150-230^{\circ} \mathrm{C}$ and $20-60 \mathrm{~min}$. This study assesses the influence of different temperature-time-flash combinations $\left(110-180^{\circ} \mathrm{C}\right.$, 5-60 min, 1-3 re-flashing) on the anaerobic degradation of secondary sludge through biochemical methane potential (BMP) tests. All the conditions tested presented higher methane production compared to the untreated sludge, and both solubilization (after the hydrolysis) and degradation (by anaerobic digestion) increased linearly when increasing the severity $(T-t)$ of the pretreatment, reaching $40 \%$ solubilization and degradation of the particulate matter at $180^{\circ} \mathrm{C}-60 \mathrm{~min}$. However, for the $180^{\circ} \mathrm{C}$ temperature, the treatment time impacted negatively on the lag phase. No influence of reflashing the pretreated matter was observed. In conclusion, thermal steam-explosion at short operation times $(5 \mathrm{~min})$ and moderate temperatures $\left(145^{\circ} \mathrm{C}\right)$ seems to be very attractive from a degradation point of view thus presenting a methane production enhancement similar to the one obtained at $180^{\circ} \mathrm{C}$ and without negative influence of the lag phase.

Key words | anaerobic digestion, BMP, secondary sludge, severity, thermal hydrolysis
\end{abstract}

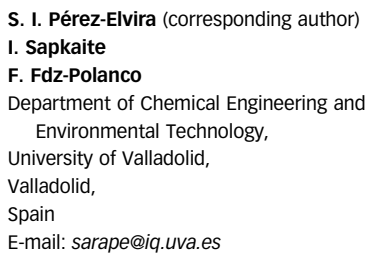

\section{INTRODUCTION}

Sludge production minimization and resource recovery are nowadays priority issues in modern wastewater treatment plants (WWTPs) due to stringent environmental laws on wastewater treatment and sludge disposal routes. In spite of the suitability of anaerobic digestion as the key management and valorization option, the biological nature of sludge, especially secondary, limits both digestion and dewatering. Thermal hydrolysis has proven to optimize the anaerobic digestion of biological sludge by accelerating the rate-limiting hydrolysis step, improving biogas production, volatile solids removal and sludge dewatering, preventing foam formation, and removing pathogens.

However, the reported results on performance are difficult to summarize and compare, varying depending on the sludge source and treatment conditions (Carrère et al. 20Io).

According to the reviews by Carrère et al. (2010) and Hii et al. (2014) most of the laboratory- or pilot-scale studies report optimum treatment temperature in the range of $160-180^{\circ} \mathrm{C}, 180^{\circ} \mathrm{C}$ being the generally accepted doi: $10.2166 /$ wst.2015.294 temperature limit to avoid inhibition by formation of refractory compounds at high temperatures (Dwyer et al. 2008; Ariunbaatar et al. 2014).

With regard to the treatment time, the range 30-60 min is mostly accepted, but recent studies (Donoso-Bravo et al. 20Io) found that for the pretreatment at $170{ }^{\circ} \mathrm{C}$ temperature, the time (ranging from 5 to $30 \mathrm{~min}$ ) did not influence sludge digestion, suggesting that long operation carried out at full scale could be unnecessary.

Regarding the effect of the flash, none of the bibliographic information analyses whether the re-flashing (repetition of sudden decompression without extra heat consumption) of sludge can enhance even further the solubilization of organic matter, thereby increasing the methane production.

From a full-scale implementation point of view, the available information on the operation conditions of the different thermal hydrolysis commercial processes $\left(\mathrm{Cambi}^{\circledR}{ }^{\circledR}\right.$, Biothelys $^{\circledR}$, Exelys $^{\circledR}$, TPH ${ }^{\circledR}$, Lysotherm ${ }^{\circledR}$, Turbotec ${ }^{\circledR}$ ) shows that the operation conditions are in the generally accepted range 
150-230 $\mathrm{C}, 20-60 \mathrm{~min}$ and one single sudden decompression (flash). As key factors for process design and economics, the revision of these values is a matter of major interest.

This study aims at evaluating different temperaturetime-flash combinations (ranging from 110 to $180{ }^{\circ} \mathrm{C}$ and 5 to $60 \mathrm{~min}$ ) on the biochemical methane potential (BMP) of steam-exploded secondary sludge, compared to untreated samples. The results are analyzed in terms of methane yield, kinetic parameters and severity factor.

\section{MATERIALS AND METHODS}

\section{Sludge sampling}

According to Pérez-Elvira et al. (2008), the study was performed for waste activated sludge (WAS) from the municipal WWTP of Valladolid (Spain), operated at 13 day solids retention time. A single sample of sludge was thickened without polyelectrolyte to 14\%TS (79\%VS) before being fed to the thermal hydrolysis unit in all the batch experiments performed.

The anaerobic inoculum for the BMP tests was sampled from the anaerobic digester in the WWTP treating mixed sludge, and pre-incubated for 2 days at $35^{\circ} \mathrm{C}$ in a thermostated chamber prior to use in order to activate the microorganisms and to deplete most of the residual organic matter.

\section{Steam explosion pretreatment, operation variables and experimental set-up}

The thermal hydrolysis pilot plant operated (Figure 1) consists of a $20 \mathrm{~L}$ hydrolysis reactor heated with live steam (12 bar) from a boiler, and connected to an atmospheric flash tank $(100 \mathrm{~L})$ by a decompression valve that opens in

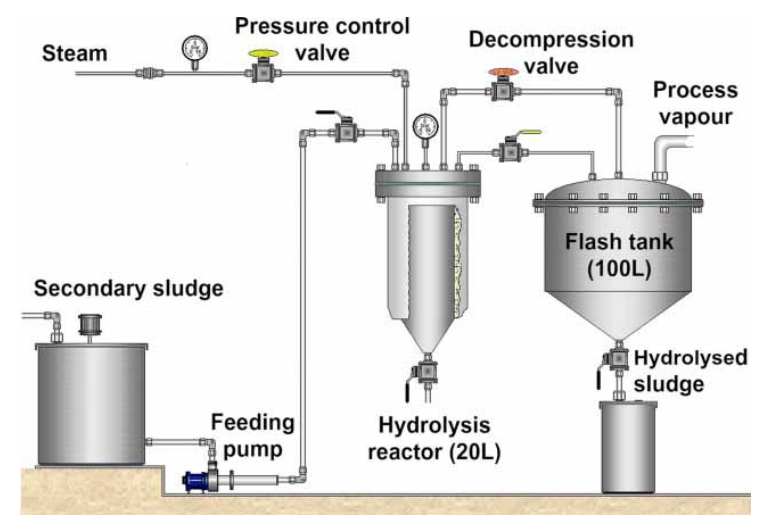

Figure 1 | Thermal pretreatment system (Fernández-Polanco et al. 2008). a steam-explosion effect (sudden decompression). The operation is batch, and automatically controlled by fixing both temperature and hydrolysis time.

To obtain the experimental plan (Table 1), a response surface methodology with Box-Behnken experimental design was used in this work. Three factors at two levels were considered: temperature $\left(110^{\circ}\right.$ and $\left.180{ }^{\circ} \mathrm{C}\right)$, time (5 and $\left.50 \mathrm{~min}\right)$ and number of flashes ( 1 and 3 ). This last variable was evaluated by re-flashing the treated sludge twice or three times. The experimental plan consisted of 15 runs, including three repetitions at the center point of the experimental design.

\section{Anaerobic digestion tests}

BMP assays at $35^{\circ} \mathrm{C}$ were conducted in triplicate in $160 \mathrm{~mL}$ serum bottles filled with $50 \mathrm{~mL}$ of a mixture of anaerobic inoculum and the corresponding substrate (untreated or treated secondary sludge) at a substrate to inoculum ratio of $0.5 \mathrm{~g} / \mathrm{g}$ (on volatile solids (VS) basis). In this test, micronutrients and macronutrients were used for optimal function of anaerobic micro-organisms. Moreover, $\mathrm{NaHCO}_{3}$ and $\mathrm{Na}_{2} \mathrm{~S}$ were added to provide a buffer capacity and avoid aerobic conditions, respectively. The methodology used was the one suggested by Angelidaki et al. (2009).

The bottles were closed with butyl septa, sealed with aluminum caps, purged with helium for $5 \mathrm{~min}$ and incubated in a

Table 1 | The Box-Behnken experimental design for thermal hydrolysis with three independent variables

\begin{tabular}{lllll} 
& $\mathbf{T}(\mathbf{C})$ & $\boldsymbol{t}(\mathbf{m i n})$ & $\log \boldsymbol{R}_{\mathbf{0}}$ & Number of flashes \\
\hline CONTROL & - & - & 0 & 0 \\
TH-1 & 110 & 5 & 1.0 & 2 \\
TH-2 & 110 & 30 & 1.8 & 1 \\
TH-3 & 110 & 30 & 1.8 & 3 \\
TH-4 & 110 & 50 & 2.0 & 2 \\
TH-5 & 145 & 5 & 2.0 & 1 \\
TH-6 & 145 & 5 & 2.0 & 3 \\
TH-7 & 145 & 30 & 2.8 & 2 \\
TH-8 & 145 & 30 & 2.8 & 2 \\
TH-9 & 145 & 30 & 2.8 & 2 \\
TH-10 & 145 & 50 & 3.0 & 1 \\
TH-11 & 145 & 50 & 3.0 & 3 \\
TH-12 & 180 & 5 & 3.1 & 2 \\
TH-13 & 180 & 30 & 3.8 & 1 \\
TH-14 & 180 & 30 & 3.8 & 3 \\
TH-15 & 180 & 50 & 4.1 & 2 \\
\hline & & & & \\
\hline
\end{tabular}


thermostated chamber at $35^{\circ} \mathrm{C}$ in an orbital shaker at $150 \mathrm{rpm} /$ min. Methane production in the BMP assays was determined by periodic measurements of pressure and biogas composition in the headspace of the bottles. Reference tests containing only anaerobic inoculum were prepared to determine the endogenous methane production of the inoculum, which was subtracted from the total methane production in the BMP tests to obtain the real methane production of the substrate. The experimental values obtained are always referred to average values, with the corresponding standard deviation.

\section{Performance parameters}

Table 2 summarizes the target parameters calculated.

It is worth mentioning that both solubilization and degradation factors (SF and DF) are calculated with respect to the particulate fraction of the chemical oxygen demand (COD), in contrast to most of the references that express these parameters with respect to the total COD. These proposed expressions are more accurate as the particulate matter is the potentially hydrolyzable fraction during the pretreatment.

And sludge biodegradability (BD) was calculated as the ratio of the experimental ( $\mathrm{mL} \mathrm{CH}_{4} / \mathrm{gCOD}$ ) to the theoretical methane production ( $\left.350 \mathrm{mLCH}_{4} / \mathrm{gCOD}_{\text {removed }}\right)$.

\section{Modelling}

Four models were considered to fine-tune the experimental data from BMP tests to theoretical equations in order to estimate kinetic parameters with a certain degree of confidence.

Based on similar studies with solid wastes (Cano Herranz 20I4), the models considered were (see Table 3): first order equation (FO), Modified Gompertz (MG) equation, transference function (TF), and logistic function (LF).

Despite differing mathematically from each other, the four models have common features: a kinetic parameter $\left(R_{m}\right.$ or $\left.\mu_{\max }\right)$ which indicates the maximum slope of the curve $\left(\mathrm{mL} \mathrm{CH}_{4} /\right.$ $\mathrm{gVS} / \mathrm{d}$ ), a maximum biogas production parameter $(\mathrm{P})$ expressed as $\mathrm{mL} \mathrm{CH}_{4} / \mathrm{gVS}$, and a lag-phase parameter $(\lambda)$, in days. $\mathrm{B}$ is the calculated methane production ( $\mathrm{mL} \mathrm{CH}_{4} / \mathrm{gVS}$ ) for each time $t$. The correlation factor $\left(R^{2}\right)$ was also calculated to assess the accuracy of each model with respect to the experimental data.

\section{Analytical methods}

Total solids (TS), VS, total chemical oxygen demand (TCOD) and soluble chemical oxygen demand (SCOD) concentrations were determined according to Standard Methods (Eaton et al. 2005). The soluble phase for SCOD was obtained by centrifugation at 5,000 rpm for $10 \mathrm{~min}$. The pressure in the headspace of the BMP bottles was measured with a pressure sensor PN 5007 (IFM, Germany), and biogas composition was determined using a gas chromatograph coupled with a thermal conductivity detector (Varian CP-3800, USA).

\section{RESULTS AND DISCUSSION}

\section{Evaluation of thermal hydrolysis operation parameters through BMP test curves}

Figure 2 presents the digestion curves obtained in the BMP tests: Figure 2(a), (b) and (c) the influence of temperature and time, whereas Figure 2(d) the influence of re-flashing.

Table 2 | Prediction parameters for the evaluation of $\mathrm{TH}$

\begin{tabular}{|c|c|c|c|}
\hline Parameter & Symbol & Units & Equation \\
\hline Severity factor & $\log R_{0}$ & - & $\log R_{0}=\log \left(t \cdot \exp \left(\frac{T-100}{14.75}\right)\right)$ \\
\hline Solubilization factor & SF & $\%$ & $\% \mathrm{SF}=\frac{(\mathrm{SCOD} / \mathrm{TCOD})_{\mathrm{TH}}-(\mathrm{SCOD} / \mathrm{TCOD})_{0}}{((\mathrm{TCOD}-\mathrm{SCOD}) / \mathrm{TCOD})_{0}} \times 100$ \\
\hline Methane potential & $\mathrm{CH}_{4}$ & $\mathrm{~mL} \mathrm{CH}_{4} / \mathrm{g} \mathrm{VS}_{\mathrm{fed}}$ & $\mathrm{CH}_{4}=\frac{\mathrm{mLCH}_{4}}{\mathrm{gVS}_{\mathrm{fed}}}$ at standard conditions $\left(0^{\circ} \mathrm{C}, 1 \mathrm{~atm}\right)$ \\
\hline Biodegradability & $\mathrm{BD}$ & $\%$ & $\% \mathrm{BD}=\frac{\mathrm{mLCH}_{4} / \mathrm{gVS}_{\mathrm{fed}}}{\left(350 \mathrm{mLCH}_{4} / \mathrm{gTCOD}_{\mathrm{rem}}\right) \cdot(\mathrm{gTCOD} / \mathrm{gVS})} \times 100$ \\
\hline Degradation factor & $\mathrm{DF}$ & $\%$ & $\% \mathrm{DF}=\frac{\left(\mathrm{mLCH}_{4} / \mathrm{gTCOD}\right)_{\mathrm{TH}}-\left(\mathrm{mLCH}_{4} / \mathrm{gTCOD}\right)_{0}}{\left(\mathrm{mLCH}_{4} / \mathrm{gTCOD}\right)_{0} \cdot((\mathrm{TCOD}-\mathrm{SCOD}) / \mathrm{TCOD})_{0}} \times 100$ \\
\hline
\end{tabular}


Table 3 | Model equations

\begin{tabular}{|c|c|c|}
\hline Model & Equation & References \\
\hline $\mathrm{FO}$ & $B=P \times\left[1-\exp \left(-\mu_{\max } \cdot t\right)\right]$ & $\begin{array}{l}\text { Pavlostathis \& } \\
\text { Giraldo- } \\
\text { Gomez (I99I) }\end{array}$ \\
\hline MG & $B=P \times \exp \left\{-\exp \left[\frac{R_{\mathrm{m}} \times e}{P}(\lambda-t)+1\right.\right.$ & $\begin{array}{l}\text { Lay et al. (I997); } \\
\text { Nopharatana } \\
\text { et al. (2007) }\end{array}$ \\
\hline $\mathrm{TF}$ & $B=P \times\left[1-\exp \left(\frac{-R_{\mathrm{m}}(t-\lambda)}{P}\right)\right]$ & $\begin{array}{l}\text { Donoso-Bravo } \\
\text { et al. (20II); } \\
\text { Redzwan \& } \\
\text { Banks (2004) }\end{array}$ \\
\hline $\mathrm{LF}$ & $B=\frac{P}{1+\exp \left[\frac{4 R_{\mathrm{m}}(\lambda-t)}{P}+2\right]}$ & $\begin{array}{l}\text { Donoso-Bravo } \\
\text { et al. (20Io); } \\
\text { Altas (2009) }\end{array}$ \\
\hline
\end{tabular}

The first evidence of these experimental results obtained is that all the conditions tested presented higher methane production in the final values for day 30 compared to the control (untreated sample), from 20\% improvement $\left(\right.$ at $110{ }^{\circ} \mathrm{C}$ ) to $40 \%$ (at $180^{\circ} \mathrm{C}$ ). Surprisingly, time was not a relevant parameter, the results for the different temperatures tested being rather similar for pretreatments at 110 and $145^{\circ} \mathrm{C}$ (Figure 1 (a) and $1(\mathrm{~b})$ ). Only at $180^{\circ} \mathrm{C}$ did the pretreatment time influence negatively the lag phase (see kinetic parameters in Table 2).

Therefore, thermal steam-explosion at short operation times (5 min) and moderate temperatures $\left(145^{\circ} \mathrm{C}\right)$ seems to be very attractive from a degradation point of view, thus presenting a methane production enhancement similar to the one obtained at $180^{\circ} \mathrm{C}$ and without negative influence of the lag phase. (a)

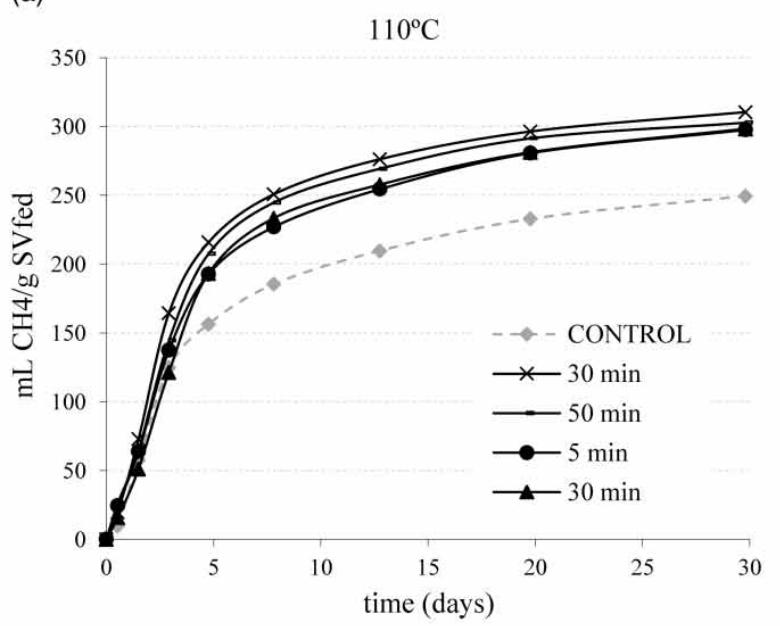

(c)

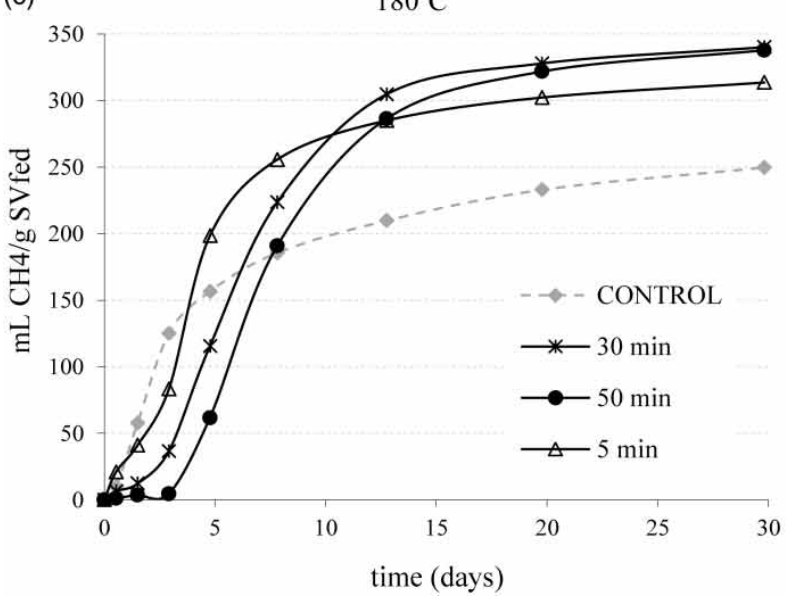

(b)

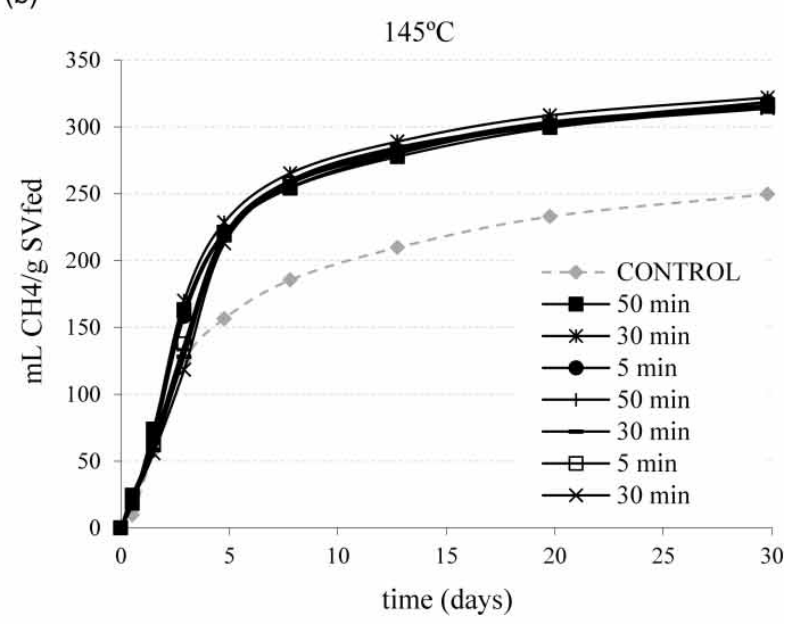

(d)

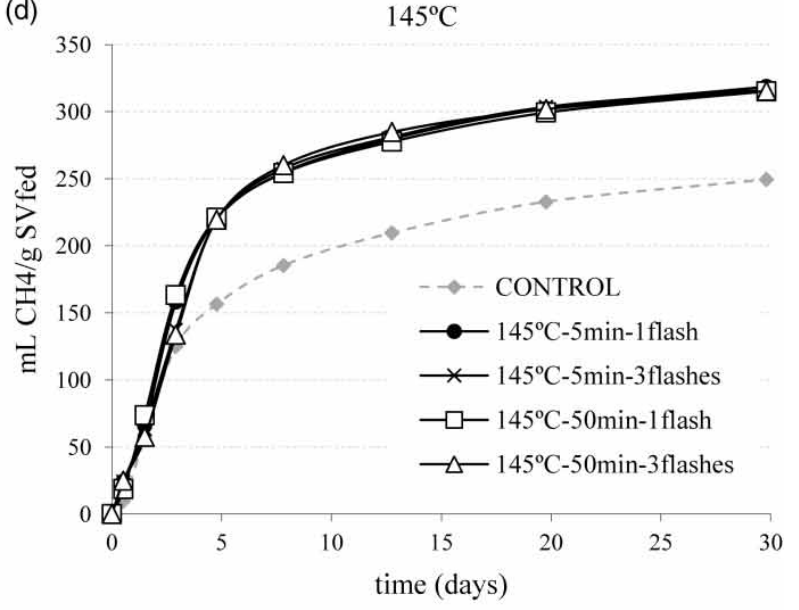

Figure 2 | Methane production curves from BMP test of the pretreated samples at $110^{\circ} \mathrm{C}(\mathrm{a}), 145^{\circ} \mathrm{C}$ (b) and $180^{\circ} \mathrm{C}(\mathrm{c})$, and after re-flashing (d). 
Figure 2(d)) clearly exhibits that neither time nor reflashing influenced the methane production.

\section{Evaluation of modeling accuracy}

The modeling approach was performed for all the samples, showing generally a good accuracy except for the tests with lag-phase. To summarize and focus the discussion, the results presented below correspond only to three samples: the untreated (CONTROL), TH-1 (pretreated, with no lag-phase) and TH-15 (pretreated, with lag-phase).

Table 4 summarizes the results of the estimated parameters obtained with the four models, and Figure 2 presents the model fit to the experimental BMP curves.

Table 4 shows that in most cases the estimated parameters were determined with a high degree of confidence $\left(R^{2}=0.98\right)$. Regarding the maximum methane production, the four models estimate similar values in all the tests. However, some differences can be observed among the different models. FO estimates the micro-organisms' growth velocity $\left(\mu_{\max }\right)$, which cannot be compared to the maximum methane production rate $\left(R_{\mathrm{m}}\right)$, which is estimated by the other models. While TF tends to overestimate this parameter, LF and MG estimate more similar values. DonosoBravo et al. (20Io) also found this coincidence between LF and MG models.

Regarding the lag-phase, it is only determined by all the tri-parametrical models (MG, TF and LF), but only MG and LF fine-tune correctly this kind of kinetic. Table 4 shows

Table 4 | Estimated parameters by the four models for control, TH-1 and TH-15 samples

\begin{tabular}{llllll} 
& & Model & & \\
\cline { 3 - 6 } Sample & Estimated parameters & MG & TF & LF & Fo \\
\hline CONTROL & $P\left(\mathrm{~mL} \mathrm{CH}_{4} / \mathrm{gS}_{\text {fed }}\right)$ & 226 & 238 & 221 & 239 \\
& $R_{\mathrm{m}}\left(\mathrm{mL} \mathrm{CH}_{4} / \mathrm{gSV}_{\text {fed }} / \mathrm{d}\right)$ & 37.4 & 52.0 & 39.9 & - \\
& $\lambda(\mathrm{d})$ & 0.105 & 0.109 & 0.387 & - \\
& $\mu \max \left(\mathrm{d}^{-1}\right)$ & - & - & - & 0.209 \\
& $R^{2}$ & 0.971 & 0.988 & 0.955 & 0.988 \\
TH-1 & $P\left(\mathrm{~mL} \mathrm{CH}_{4} / \mathrm{gS}_{\text {fed }}\right)$ & 274 & 287 & 269 & 288 \\
& $R_{\mathrm{m}}\left(\mathrm{mL} \mathrm{CH}_{4} / \mathrm{gSV}_{\text {fed }} / \mathrm{d}\right)$ & 43.3 & 60.8 & 46.7 & - \\
& $\lambda(\mathrm{d})$ & 0.077 & 0.066 & 0.403 & - \\
& $\mu \max \left(\mathrm{d}^{-1}\right)$ & - & - & - & 0.206 \\
$\mathrm{TH}-15$ & $R^{2}$ & 0.982 & 0.994 & 0.969 & 0.993 \\
& $P\left(\mathrm{~mL} \mathrm{CH}_{4} / \mathrm{gS}_{\text {fed }}\right)$ & 288 & 348 & 282 & 374 \\
& $R_{\mathrm{m}}\left(\mathrm{mL} \mathrm{CH}_{4} / \mathrm{gSV}_{\text {fed }} / \mathrm{d}\right)$ & 41.7 & 30.4 & 48.8 & - \\
& $\lambda(\mathrm{d})$ & 3.30 & 0.990 & 3.91 & - \\
& $\mu \max \left(\mathrm{d}^{-1}\right)$ & - & - & - & 0.067 \\
$R^{2}$ & 0.995 & 0.948 & 0.991 & 0.943 \\
& Average $R^{2}$ all samples & 0.989 & 0.986 & 0.981 & 0.985 \\
\hline
\end{tabular}

that in the test with 3-4 day lag-phase (TH-15), TF and FO exhibited a poor correlation $\left(R^{2}=0.948\right.$ and 0.943 , respectively), showing that these models do not fit lagphase kinetics. This experimental evidence is very clear in Figure 3, where only MG and LF follow accurately the experimental points in $\mathrm{TH}-15$, and is consistent with the experimental results of Cano Herranz (20I4) performed with grease waste.

Comparing the accuracy of the four models, the final conclusion is that the MG equation results to be in general the most appropriate to fine-tune thermal hydrolyzed secondary sludge kinetics, showing an average regression coefficient $R^{2}$ of 0.989 . Similar accuracy values were obtained by Donoso-Bravo et al. (20I0) and Cano Herranz (20I4) with solid substrates and thermally pretreated sludge, respectively.

\section{Relationship between pretreatment severity and performance parameters}

Most of the studies on thermal hydrolysis of secondary sludge report that it is an effective pretreatment method to improve anaerobic digestion kinetics and methane production from sludge (Wilson \& Novak 2009; Oosterhuis et al. 20I4; Zhang et al. 20I4). However, the quantification of this improvement is difficult to measure by the sole observation of BMP curves and the information that could be extracted can be inaccurate.

Therefore, Table 5 summarizes for the different operation conditions the prediction parameters calculated from the experimental curves (SF, methane, BD and DF), together with the parameters obtained with the application of the MG (which was the most accurate).

As previously stated, thermal pretreatment improved the anaerobic digestion of the sewage sludge evaluated ('control': $47 \%$ biodegradable, $250 \mathrm{~mL} \mathrm{CH}_{4} / \mathrm{g} \mathrm{VS}_{\mathrm{fed}}$ ) by increasing its $\mathrm{BD}$ and methane potential for all the conditions tested.

When correlating the main parameters with respect to the severity factor (Figure 4), some interesting behaviors can be observed.

First, the SF increased linearly with the severity as a direct consequence of the cell disruption that takes place during the thermal pretreatment (Dwyer et al. 2008), obtaining a solubilization of $40 \%$ of the particulate matter at the highest severity factor evaluated $\left(\log R_{0}=4.1\right.$ in TH-14\&15). The same results were obtained for the DF (maximum 40\% degradation of the particulate matter in $\mathrm{TH}-14 \& 15)$, thus meaning that all the organic matter 
MG

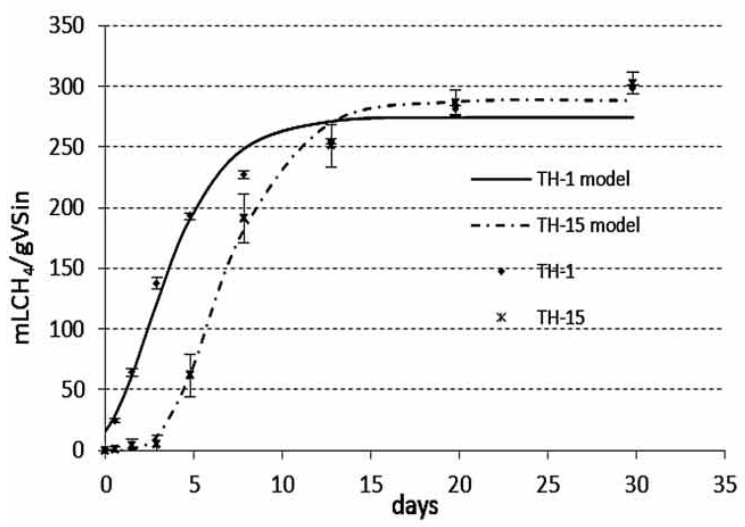

TF

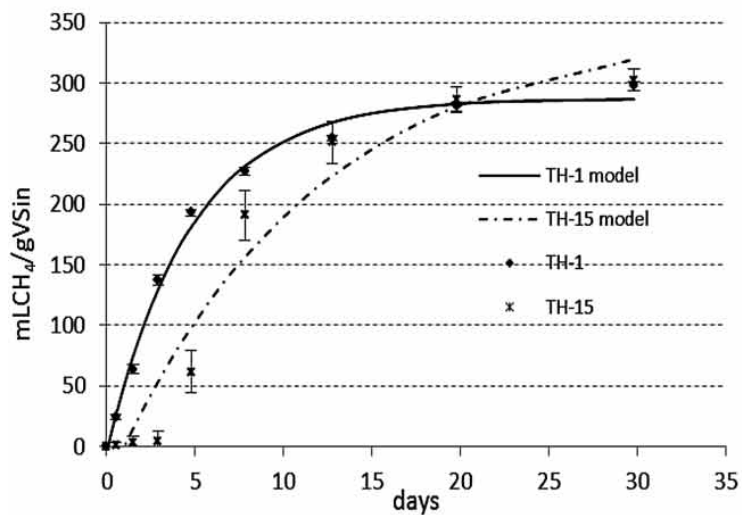

LF

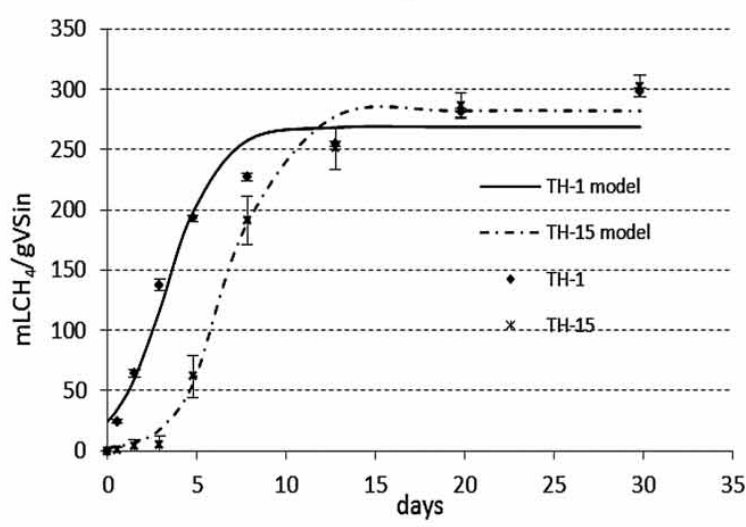

FO

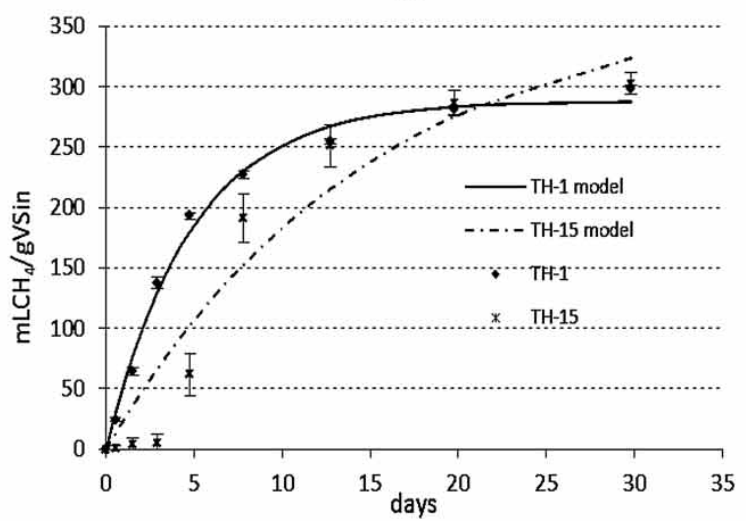

Figure 3 | Experimental (points) and estimated (lines) methane production curves.

Table 5 | Experimental set-up and corresponding results

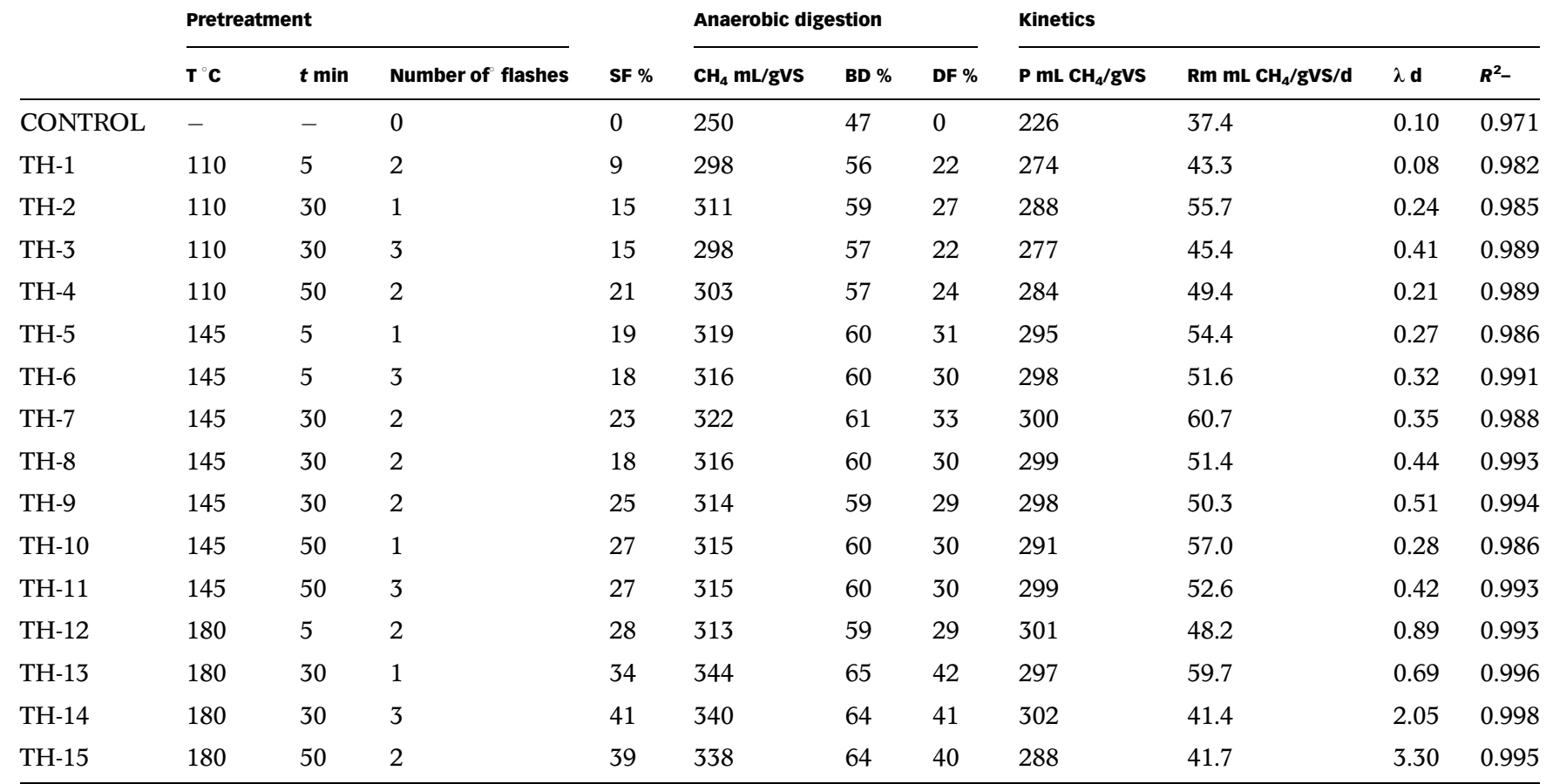



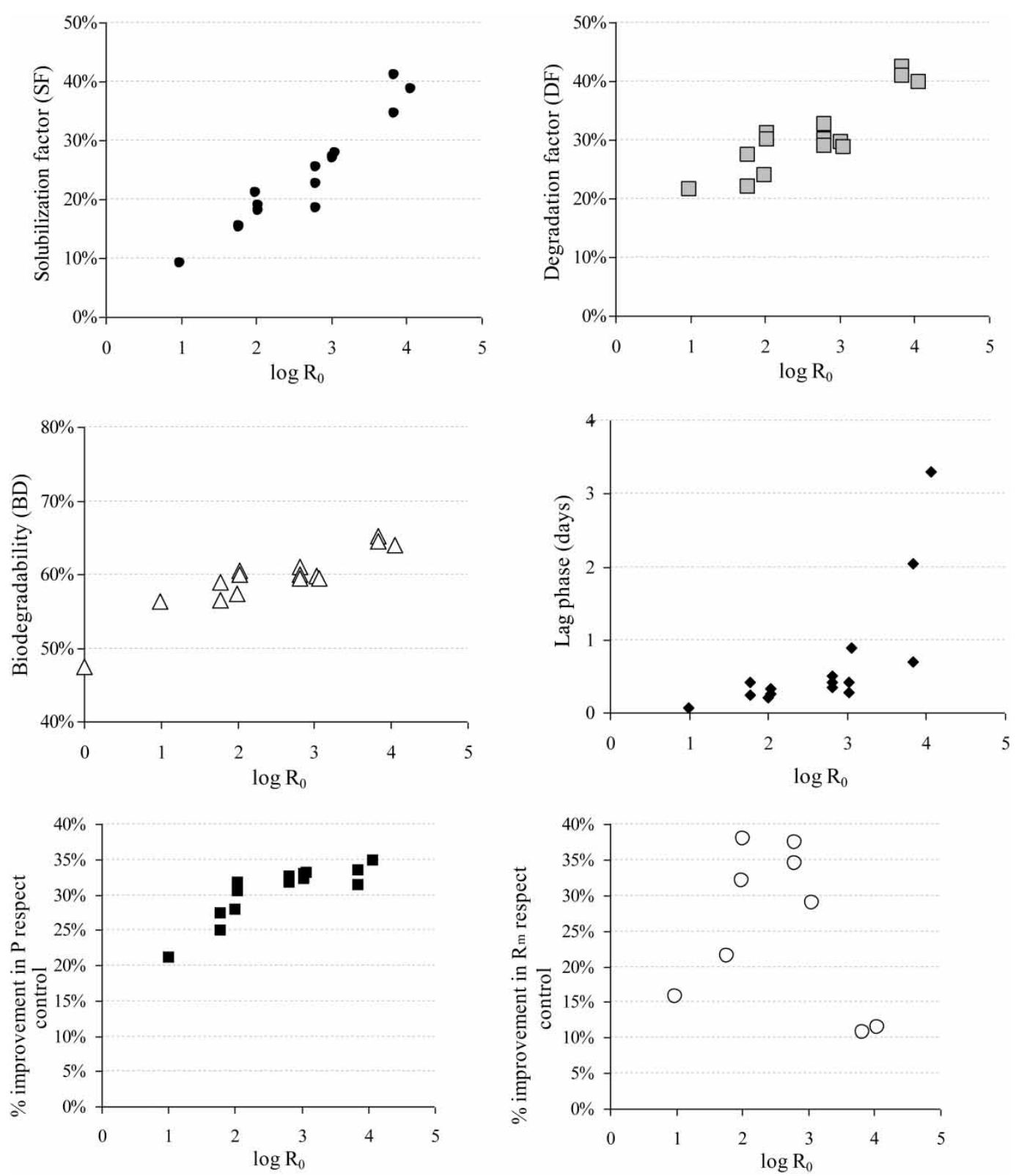

Figure 4 | Relationship between the different performance parameters and the severity factor ( $\left.\log R_{0}\right)$.

solubilized was degraded to methane. Correspondingly, the BD increased linearly, from 47 to $64 \%$ at $180{ }^{\circ} \mathrm{C}-50 \mathrm{~min}$ pretreatment (TH-14). This linear link between COD solubilization and methane production is consistent with the results obtained by Carrère et al. (2008).

The lag phase increased dramatically from $\lambda=0$ in the fresh control up to 3.5 days for severity $\log R_{0}>3\left(180{ }^{\circ} \mathrm{C}\right.$, $t>30 \mathrm{~min})$, as previously presented in Figure $1(\mathrm{c}))$. It is generally considered that the extreme thermal hydrolysis conditions could lead to producing some slowly biodegradable or non-biodegradable recalcitrant compounds (in most $\mathrm{TH}$ cases melanoidins), making slower the multiplication of necessary bacteria and decreasing soluble phase consumption (Dwyer et al. 2008; Ariunbaatar et al. 2014).

When comparing the improvement in the methane production ( $\mathrm{mL} \mathrm{CH}_{4} / \mathrm{g}$ VSfed) and in the production rate $(\mathrm{mL}$ $\mathrm{CH}_{4}$ /gVSfed.d), it can be observed that although the methane production increased with the severity (as previously commented), the methane production rate did not show the same trend, and exhibited an optimum at a severity factor of 3, then decreasing sharply, again pointing to the 
fact that the most severe pretreatment could lead to the formation of recalcitrant compounds.

An analysis of variance (ANOVA) was done for methane production in order to test the model significance and suitability. The significance of each coefficient was determined using the $F$-value test, at a 95\% confidence level.

The results of the variance analysis are presented in Table 6. From there it can be concluded that coefficient for the linear effect of the temperature (A) on methane production is a statistically significant model term at 95\% confidence level $(P<0.05)$, thus confirming that only temperature affected the increment of methane production.

Although neither linear effects of the time (B) nor of the flash $(\mathrm{C})$ on the methane production are statistically significant, the linear effect of the time (B) on methane production is more valid than the linear effect of the flash $(\mathrm{C})$.

Based on the model, a maximum methane production $345 \mathrm{~mL} \mathrm{CH}_{4} / \mathrm{g} \mathrm{VS}$ (40\% increase) was predicted at conditions: $180^{\circ} \mathrm{C}, 45 \mathrm{~min}$ and 1 flash, with a desirability of 0.882 .

\section{CONCLUSIONS}

This paper assesses through BMP tests of the influence of different temperature-time-flash thermal hydrolysis pretreatment conditions and combinations on the anaerobic degradation of secondary sludge. All the conditions tested (110-180 ${ }^{\circ} \mathrm{C}, 10-50 \mathrm{~min}, 1-3$ flashes) presented higher methane production, exhibiting a maximum improvement of $40 \%$ solubilization and subsequent degradation of the particulate matter. Generally, the correlation between the severity of the pretreatment and the performance of the subsequent digestion was linear. However, only temperature showed a positive influence on the methane production,

Table 6 | ANOVA table for the methane production of WAS using TH

\begin{tabular}{lccccc} 
Source & Sum of squares & DF & Mean square & F-value & P-value \\
\hline A: Temperature & $1,953.13$ & 1 & $1,953.13$ & 48.91 & 0.0001 \\
B: Time & 78.125 & 1 & 78.125 & 1.96 & 0.1995 \\
C: Flash & 50.0 & 1 & 50.0 & 1.25 & 0.2956 \\
AB & 100.0 & 1 & 100.0 & 2.50 & 0.1522 \\
BB & 123.626 & 1 & 123.626 & 3.10 & 0.1165 \\
CC & 74.5728 & 1 & 74.5728 & 1.87 & 0.2089 \\
Error total & 319.481 & 8 & 39.9351 & & \\
Total (corr.) & $2,713.73$ & 14 & & & \\
\hline
\end{tabular}

Critical value $\left(F_{0}\right)$ for the $F$-test: $5.32\left(F_{0.05}, 1,8\right)$. although at extreme thermal hydrolysis conditions, the lag phase increased dramatically, probably due to the formation of recalcitrant compounds. Time and re-flashing exhibited no significant influence.

\section{REFERENCES}

Angelidaki, I., Alves, M., Bolzonella, D., Borzacconi, L., Campos, J. L., Guwy, A. J., Kalyuzhnyi, S., Jenicek, P. \& Van Lier, J. B. 2009 Defining the biomethane potential (BMP) of solid organic wastes and energy crops: a proposed protocol for batch assays. Water Science and Technology 59 (5), 927-934.

Altas, L. 2009 Inhibitory effect of heavy metals on methane producing anaerobic granular sludge. Journal of Hazardous Materials 162 (2-3), 1551-1556.

Eaton, A. D., Clesceri, L. S. \& Greenberg, A. E. 2005 Standard Methods for the Examination of Water and Wastewater, 21st edn. American Public Health Association/American Water Works Association/Water Environment 633 Federation, Washington, DC.

Ariunbaatar, J., Panico, A., Esposito, G., Pirozzi, F. \& Lens, P. N. L. 20I4 Pretreatment methods to enhance anaerobic digestion of organic solid. Applied Energy 123, 143-156.

Cano Herranz, R. 20I4 Pretreatment Technologies to Enhance Solid Wastes Anaerobic Digestion. PhD thesis, Department of Chemical Engineering and Environmental Technology, University of Valladolid, Spain.

Carrère, H., Bougrier, C., Castets, D. \& Delgenes, J. P. 2008 Impact of initial biodegradability on sludge anaerobic digestion enhancement by thermal pretreatment. Journal of Environmental Science and Health. Part A, Toxic/hazardous Substances \& Environmental Engineering 43 (13), 1551-1555.

Carrère, H., Dumas, C., Battimelli, A., Batstone, D., Delgenes, J., Steyer, J. \& Ferrer, I. 2oro Pretreatment methods to improve sludge anaerobic degradability: a review. Journal of Hazardous Materials 183, 1-15.

Donoso-Bravo, A., Pérez-Elvira, S. I. \& Fdz-Polanco, F. 2010 Application of simplified models for anaerobic biodegradability tests. Evaluation of pre-treatment processes. Chemical Engineering Journal 160 (2), 607-614.

Donoso-Bravo, A., Pérez-Elvira, S. I., Aymerich, E. \& FdzPolanco, F. 20II Assessment of the influence of thermal pretreatment time on the macromolecular composition and anaerobic biodegradability of sewage sludge. Bioresource Technology 102, 660-666.

Dwyer, J., Starrenburg, D., Tait, S., Barr, K., Batstone, D. J. \& Lant, P. 2008 Decreasing activated sludge thermal hydrolysis temperature reduces product colour, without decreasing degradability. Water Research 42 (18) 4699-4.

Fernández-Polanco, F., Velázquez, R., Pérez-Elvira, S. I., Casas, C., Del Barrio, D., Cantero, F. J., Fernández-Polanco, M., Rodríguez, P., Panizo, L., Serrat, J. \& Rouge, P. 2008 Continuous thermal hydrolysis and energy integration in sludge anaerobic digestion plants. Water Science and Technology 57 (8), 1221-1226. 
Hii, K., Baroutina, S., Parthasarathy, R., Gapes, D. J. \& Eshtiaghi, N. 20I4 A review of wet air oxidation and thermal hydrolysis technologies. Bioresource Technology 155, 289-299.

Lay, J. J., Li, Y. Y. \& Noike, T. 1997 Influences of pH and moisture content on the methane production in high-solids sludge digestion. Water Research 31 (6), 1518-1524.

Nopharatana, A., Pullammanappallil, P. C. \& Clarke, W. P. 2007 Kinetics and dynamic modelling of batch anaerobic digestion of municipal solid waste in a stirred reactor. Waste Management 27 (5), 595-603.

Oosterhuis, M., Ringoot, D., Hendriks, A. \& Roeleveld, P. 2014 Thermal hydrolysis of waste activated sludge at Hengelo wastewater treatment plant, The Netherlands. Water Science and Technology 70 (1), 1-7.

Pavlostathis, S. G. \& Giraldo-Gomez, E. 199I Kinetics of anaerobic treatment: A critical review. Critical Reviews in Environmental Control 21 (5-6), 411-490.
Pérez-Elvira, S. I., Fdz-Polanco, F., Fdz-Polanco, M., Rodríguez, P. \& Rougé, P. 2008 Hydrothermal multivariable approach: fullscale feasibility study. Electronic Journal of Biotechnology 11, 7-8.

Redzwan, G. \& Banks, C. 2004 The use of a specific function to estimate maximum methane production in a batch-fed anaerobic reactor. Journal of Chemical Technology and Biotechnology 79 (10), 1174-1178.

Wilson, C. A. \& Novak, J. T. 2009 Hydrolysis of macromolecular components of primary and secondary wastewater sludge by thermal hydrolytic pretreatment. Water Research 43 (18), 4489-4498.

Zhang, L., Zhang, Y., Zhang, Q., Verpoort, F., Cheng, W., Caoi, L. \& Li, M. 2014 Sludge gas production capabilities under various operational conditions of the sludge thermal hydrolysis pretreatment process. Journal of the Energy Institute 87, 121-126.

First received 13 January 2015; accepted in revised form 26 May 2015. Available online 9 June 2015 


\section{CHAPTER 5}

Sapkaite I, Barrado E, Fdz-Polanco F, Pérez-Elvira S.I (2017) Journal of Environmental Management 192, 25-30

\section{Optimization of a thermal hydrolysis process for sludge pre-treatment}



Research article

\title{
Optimization of a thermal hydrolysis process for sludge pre-treatment
}

\author{
I. Sapkaite ${ }^{\text {a }}$, E. Barrado ${ }^{\text {b }}$, F. Fdz-Polanco ${ }^{\text {a }}$, S.I. Pérez-Elvira ${ }^{\text {a, * }}$ \\ ${ }^{a}$ Department of Chemical Engineering and Environmental Technology, University of Valladolid, Spain \\ ${ }^{\mathrm{b}}$ Department of Analytical Chemistry, University of Valladolid, Spain
}

\section{A R T I C L E I N F O}

\section{Article history:}

Received 25 October 2016

Received in revised form

13 January 2017

Accepted 19 January 2017

\section{Keywords:}

Waste activated sludge

Methane production

Response surface methodology

Solubilisation

Thermal hydrolysis

\begin{abstract}
A B S T R A C T
At industrial scale, thermal hydrolysis is the most used process to enhance biodegradability of the sludge produced in wastewater treatment plants. Through statistically guided Box-Behnken experimental design, the present study analyses the effect of $\mathrm{TH}$ as pre-treatment applied to activated sludge. The selected process variables were temperature $\left(130-180{ }^{\circ} \mathrm{C}\right)$, time $(5-50 \mathrm{~min})$ and decompression mode (slow or steam-explosion effect), and the parameters evaluated were sludge solubilisation and methane production by anaerobic digestion. A quadratic polynomial model was generated to compare the process performance for the 15 different combinations of operation conditions by modifying the process variables evaluated. The statistical analysis performed exhibited that methane production and solubility were significantly affected by pre-treatment time and temperature. During high intensity pre-treatment (high temperature and long times), the solubility increased sharply while the methane production exhibited the opposite behaviour, indicating the formation of some soluble but non-biodegradable materials. Therefore, solubilisation is not a reliable parameter to quantify the efficiency of a thermal hydrolysis pre-treatment, since it is not directly related to methane production. Based on the operational parameters optimization, the estimated optimal thermal hydrolysis conditions to enhance of sewage sludge digestion were: $140-170{ }^{\circ} \mathrm{C}$ heating temperature, $5-35 \mathrm{~min}$ residence time, and one sudden decompression.
\end{abstract}

๑) 2017 Elsevier Ltd. All rights reserved.

\section{Introduction}

In a conventional wastewater treatment plant, up to $60 \%$ of chemical oxygen demand (COD) initially present in the influent is recovered as a mixture of primary and activated sludge (Garrido et al., 2013). A new perspective is being generated due to the increase of the amount of sewage sludge and its disposal limitation by reason of strict environmental regulations, effective methods of making full use of sludge's rich organic components are on continuing interest (Zhang et al., 2014). Anaerobic digestion still appears as the most suitable method to treat the sludge due to its limited environmental impact, high potential for energy recovery as biogas, and reduction in the amount of biosolids to be disposed (Ariunbaatar et al., 2014). It is well known that for solid wastes the hydrolysis (liquefaction or solubilisation) step is the main rate limiting factor for digestion. The introduction of a physical, chemical or biological pre-treatment step before digestion has

\footnotetext{
* Corresponding author.

E-mail address: sarape@iq.uva.es (S.I. Pérez-Elvira).
}

demonstrated to improve the global kinetics and performance of the process.

On an industrial scale, the thermal hydrolysis represents the most profitable and reliable alternative (Cano et al., 2015). The main drivers for the use of thermal hydrolysis is the better energy balance due to the increase on biogas production and on better quality of the biosolids produced after digestion, both factors positively affect the operational cost of the treatment plant. From a disposal point of view, it is important to note that the hydrolysed sludge is sterilised at elevated temperatures and complies with the Environmental Protection Agency (EPA) requirements for Class A sludge.

Although nowadays developed at industrial scale (Cambi ${ }^{\circledR}$, Biothelys ${ }^{\mathbb{R}}$, Exelys $^{\mathbb{R}}, \mathrm{TPH}^{\mathbb{R}}$, Lysotherm ${ }^{\mathbb{R}}$, Turbotec $\left.{ }^{\mathbb{R}}\right)$, there is no general agreement on the optimum operation conditions.

Two different mechanisms can be applied to hydrolyse the sludge: i) thermal effect based on the single action of elevated temperatures and ii) steam explosion generated by a sudden decompression (Pérez-Elvira et al., 2008).

According to some researches, heating temperature and duration of the thermal pre-treatment depend on the nature of the 
sludge (Ariunbaatar et al., 2014; Appels et al., 2008). The generally accepted operation conditions vary between 150 and $230{ }^{\circ} \mathrm{C}$ temperature, with time ranging from 20 to $60 \mathrm{~min}$. Regarding the steam explosion option, some commercial processes flash the sludge, while other commercial technologies do not use this steam explosion mechanism. There is no bibliographical reference evaluating if flashing or re-flashing (several sudden decompressions) can further enhance the solubilisation of organic matter thereby increasing the methane production. However, the recovery of steam when flashing the sludge can be a clear economic advantage by steam recovery.

The objective of this study was therefore to determine the optimum conditions for thermal hydrolysis of waste activated sludge after studying the combined effect of pre-treatment temperature, time and flash by Response Surface Method (RSM) using the BoxBehnken experimental design (BBD). An optimal combination of factors that maximize methane production is proposed and analyzed.

\section{Materials and methods}

\subsection{Sludge sampling}

The study was performed with a single sample of waste activated sludge (WAS), provided by the municipal waste water treatment plant of Valladolid (Spain). According to Pérez-Elvira et al. (2008), the sludge was thickened without polyelectrolyte to $14 \%$ TS (73\% VS) to perform the study with concentrated sludge, which is the real operation in pre-treatment units.

The anaerobic inoculum for the biochemical methane potential (BMP) tests was sampled from the anaerobic digester in the WWTP treating mixed sludge, and pre-incubated for 2 days at $35^{\circ} \mathrm{C}$ in a thermostated chamber prior to use to activate the microorganisms and to deplete most residual organic matter.

\subsection{Thermal pre-treatment procedure}

The thermal hydrolysis pilot plant operated (Fig. 1) consisted of a $20 \mathrm{~L}$ hydrolysis reactor heated with live steam (12 bars) from a boiler, and connected to an atmospheric flash vessel $(100 \mathrm{~L})$ by a decompression valve. The operation is batch, controlling heating temperature and time. The decompression is also controlled by an automatic decompression valve, that reliefs the reactor pressure slowly (no flashing) or suddenly (in a steam-explosion effect). When the flash takes place, the hydrolysed solids are collected in the flash vessel at atmospheric pressure.

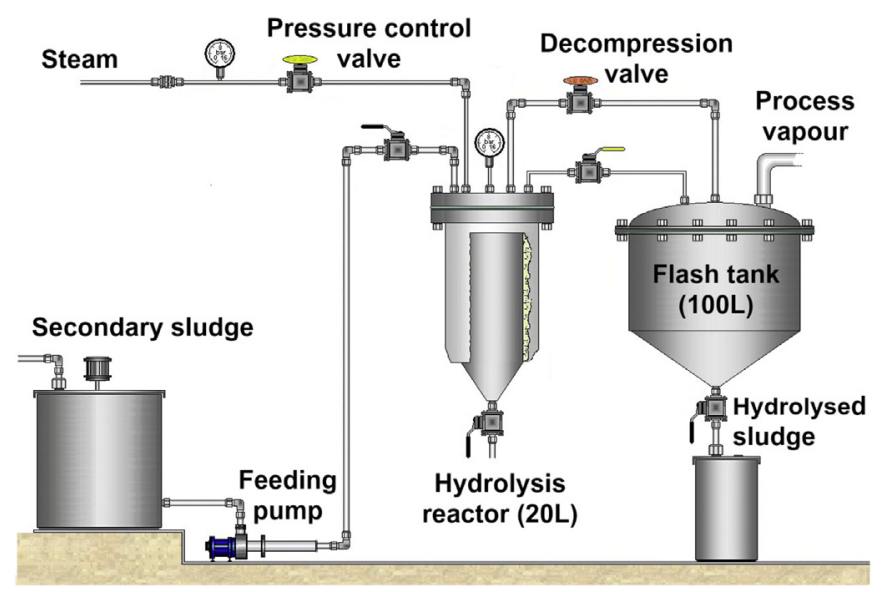

Fig. 1. Thermal pre-treatment system (Fernández-Polanco et al., 2008).

\subsection{Anaerobic digestion tests}

Biochemical methane potential (BMP) tests were performed in triplicate assays using $300 \mathrm{ml}$ serum bottles, filled with $100 \mathrm{ml}$ of a mixture of anaerobic inoculum and the corresponding substrate at a substrate to inoculum ratio (SIR) of $0.5 \mathrm{~g} / \mathrm{g}$ (on volatile solids (VS) basis). In this test, micronutrients and macronutrients were added ensuring no nutritional limitation for optimal function of anaerobic microorganisms. Moreover, $\mathrm{NaHCO}_{3}$ and $\mathrm{Na}_{2} \mathrm{~S}$ were added to provide buffer capacity and avoid aerobic conditions respectively. The methodology used was based on the one suggested by Angelidaki et al. (2009).

The bottles were incubated in a thermostated chamber at $35^{\circ} \mathrm{C}$ in an orbital shaker at $150 \mathrm{rpm} / \mathrm{min}$. Methane production in the BMP tests was determined by periodic measurements of pressure and biogas composition.

\subsection{Analytical methods and performance parameters}

Total solids (TS) and volatile solids (VS) concentrations were determined according to Standard Methods (21st edition, 2005). The soluble phase for chemical oxygen demand (SCOD) was obtained by centrifugation at $5000 \mathrm{rpm}$ for $10 \mathrm{~min}$ and filtration using a $47 \mathrm{~mm}$ hydrophilic Glass Fiber filter with a $0.7 \mu \mathrm{m}$ pore size (AP40). The total COD was obtained by a direct COD analysis.

The pressure in the headspace of the BMP bottles was measured with a pressure sensor PN 5007 (IFM, Germany), and biogas composition was determined using a gas chromatograph coupled to a thermal conductivity detector (Varian CP-3800, USA).

Two performance parameters were calculated: solubilisation and methane production increase.

The solubilisation factor (SB) (Equation (1)) was calculated with respect to the particulate fraction of the chemical oxygen demand (TCOD-SCOD), in contrast to the most of the references (Jung et al., 2015; Kim et al., 2015; Appels et al., 2010) that express this parameter with respect to the total TCOD. This proposed expression is more accurate as the particulate matter is the potentially hydrolysable fraction during the pre-treatment.

$\% S B=\frac{(\mathrm{SCOD} / \mathrm{TCOD})_{\mathrm{TH}}-(\mathrm{SCOD} / \mathrm{TCOD})_{0}}{((\mathrm{TCOD}-\mathrm{SCOD}) / \mathrm{TCOD})_{0}} \times 100$

The specific methane production was evaluated according to Equation (2):

$\mathrm{CH}_{4}=\frac{m L C H_{4}}{g V S_{f e d}}$, at standard conditions $\left(0^{\circ} \mathrm{C}, 1 \mathrm{~atm}\right)$

And the performance of the digestion was calculated by comparing the $\mathrm{CH}_{4}$ values obtained for the treated samples with respect to the untreated WAS, calculating the increase in methane production (Equation (3)):

$\% \mathrm{CH}_{4}=\frac{\left(\mathrm{CH}_{4}\right)_{T H}-\left(\mathrm{CH}_{4}\right)_{0}}{\left(\mathrm{CH}_{4}\right)_{0}} \times 100$

\subsection{Experimental design}

In order to statistically and mathematically determine the optimal conditions of the key operational conditions and the effects of their interactions on the global efficiency of the process, RSM with Box-Behnken experimental Design BBD (Benito-Roman et al., 2013; Jung et al., 2015; Sarat Chandra et al., 2014) was used in this work. 
Three factors at two levels were considered: temperature (130 and $180^{\circ} \mathrm{C}$ ), time ( 5 and $50 \mathrm{~min}$ ) and type of decompression ( 0 and 2 ). The value 0 means that the reactor pressure was relieved slowly, and the hydrolysed sludge was cooled directly without leaving the reactor. Value 2 indicates that the treated sludge was re-flashed twice (just decompressed, not heated twice).

The resulting experimental plan consisted of 15 runs (see Table 1), including three repetitions at the center point of the experimental design.

In order to develop the regression equation, the relationship between the coded values and actual values are described according to the following Equation (4):

$x=\frac{x_{j}-x_{0}}{\Delta x}$

where $\mathrm{x}$ is the coded value, $\mathrm{x}_{\mathrm{j}}$ is the corresponding actual value, $\mathrm{x}_{0}$ is the actual value in the center of the domain, and $\Delta x$ is the increment of $\mathrm{x}_{\mathrm{j}}$ corresponding to a variation of one unit of $\mathrm{x}$.

The relationship between the variables and responses was correlated with a quadratic polynomial Equation (5), that was fitted as follows:

$Y=\beta_{0}+\sum_{j=1}^{k} \beta_{j} X_{j}+\sum_{j=1}^{k} \beta_{j j} X_{j}^{2}+\sum_{i=1}^{k} \sum_{j=1}^{k} \beta_{i j} X_{i} X_{j}$

where $\mathrm{Y}$ is the estimated response variable to be optimized, $\mathrm{Xj}$ are the variables evaluated, $\beta_{0}$ is the constant, $\beta_{\mathrm{j}}$ is the linear coefficient, $\beta_{\mathrm{jj}}$ is a quadratic coefficient and $\beta_{\mathrm{ij}}$ is the interactive coefficient.

An analysis of variance (ANOVA) with $95 \%$ confidence level was done for response variable in order to test the model significance and suitability. The significance of each coefficient was determined using the F-value test, at a 95\% confidence level.

\section{Results and discussion}

\subsection{Experimental set-up and results}

Table 1 summarizes the experimental set-up together with the results obtained for the response variables evaluated (solubilisation and methane production). The CONTROL corresponds to the untreated WAS.

From these values, the effect of heating temperature, hydrolysis time and type of decompression (number of flashes) is analyzed. It

Table 1

Box-Behnken experimental design for the thermal hydrolysis and experimental results.

\begin{tabular}{|c|c|c|c|c|c|c|}
\hline \multirow[t]{2}{*}{ Trials } & \multicolumn{3}{|c|}{ Pre-treatment } & \multicolumn{3}{|l|}{ Results } \\
\hline & $\mathrm{T}\left({ }^{\circ} \mathrm{C}\right)$ & $\mathrm{t}(\min )$ & No. of flashes & SB (\%) & $\mathrm{CH}_{4}(\mathrm{~mL} / \mathrm{gVS})$ & $\Delta \mathrm{CH}_{4}(\%)$ \\
\hline CONTROL & - & - & - & 0 & 220 & - \\
\hline TH-1 & 150 & 50 & 0 & $40 \%$ & 318 & $45 \%$ \\
\hline TH-2 & 130 & 50 & 1 & $34 \%$ & 320 & $45 \%$ \\
\hline TH-3 & 130 & 5 & 1 & $30 \%$ & 316 & $44 \%$ \\
\hline TH-4 & 180 & 30 & 2 & $39 \%$ & 339 & $54 \%$ \\
\hline TH-5 & 150 & 5 & 2 & $31 \%$ & 312 & $42 \%$ \\
\hline TH-6 & 180 & 5 & 1 & $39 \%$ & 325 & $48 \%$ \\
\hline $\mathrm{TH}-7$ & 180 & 50 & 1 & $39 \%$ & 340 & $55 \%$ \\
\hline TH-8 & 150 & 30 & 1 & $36 \%$ & 336 & $53 \%$ \\
\hline TH-9 & 150 & 30 & 1 & $35 \%$ & 361 & $64 \%$ \\
\hline TH-10 & 150 & 30 & 1 & $37 \%$ & 378 & $72 \%$ \\
\hline TH-11 & 180 & 30 & 0 & $41 \%$ & 312 & $42 \%$ \\
\hline TH-12 & 150 & 50 & 2 & $38 \%$ & 335 & $52 \%$ \\
\hline TH-13 & 150 & 5 & 0 & $31 \%$ & 300 & $36 \%$ \\
\hline TH-14 & 130 & 30 & 0 & $33 \%$ & 276 & $25 \%$ \\
\hline TH-15 & 130 & 30 & 2 & $33 \%$ & 296 & $35 \%$ \\
\hline
\end{tabular}

can be noticed that all the pre-treatments evaluated increase the solubilisation and the methane production with respect to the untreated WAS. The results range between 30 and $41 \%$ solubilisation increase and $25-72 \%$ increase in methane production. However, and as will be analyzed, no direct correlation was observed between both responses.

\subsection{Effect of $T H$ variables on the WAS solubilisation}

Fig. 2 represents graphically the influence of the three variables on the waste activated sludge solubilisation. The results clearly exhibit that the increase in sludge solubility is mainly affected by temperature and time, in a rather linear trend: solubilisation is enhanced as the pre-treatment temperature and time increase. The maximum increase in soluble COD is therefore obtained in the most extreme operating conditions ( $180{ }^{\circ} \mathrm{C}$ and 50 min heating).

On the other hand, the decompression effect can be considered negligible.

From the analysis of variance evaluation, presented in Table 2, the obtained coefficients for the linear effect of the temperature (A) and time (B) on the WAS solubility are statistically significant model terms at $95 \%$ confidence level $(p<0.05)$. These results confirm that the temperature and time have a major effect on the sludge solubilisation during the thermal hydrolysis process.

Based on the ANOVA results, Equation (6) was obtained using Equation (5) to fit the experimental data of the sludge solubilisation, being $\mathrm{X}_{1}$ the heating temperature, $\mathrm{X}_{2}$ the hydrolysis time and $\mathrm{X}_{3}$ the decompression mode.

$$
\begin{aligned}
S B(\%)= & 2.29409+0.188889 * X_{1}+0.521411 * X_{2} \\
& +0.111111 * X_{3}-0.00177778 * X_{1} * X_{2} \\
& -0.00204586 * X_{2}^{2}-0.0222222 * X_{2} * X_{3}
\end{aligned}
$$

The model was considered valid because the criteria $\mathrm{r}^{2}>0.8$ was satisfied $\left(r^{2}=0.878\right)$ (Bup Nde et al., 2012). Fig. 3 presents the three-dimensional response surface plot and two dimensional contour plot for the solubilisation factor (\%SB) obtained from Equation (6) for the interaction between temperature and time (sudden decompression in 1 flash was maintained constant).

The graphs reveal that for the evaluated operation ranges of heating temperature and time, the more severe intensity of the thermal pre-treatment (higher temperature and longer times), the higher the solubilisation achieved. These results are in agreement with those obtained by other authors confirming that solubilisation efficiency increase proportional to the temperature rise. Higher pre-treatment temperatures enhance extracellular polymeric substances (EPS) solubilisation and cell lysis (Zhang et al., 2015;

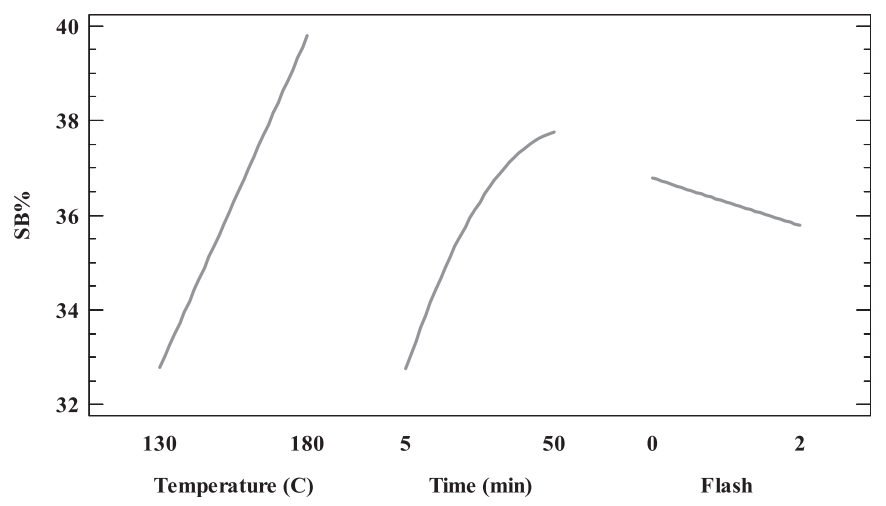

Fig. 2. Influence of the factors evaluated on WAS solubilisation. 
Table 2

ANOVA table for WAS solubility after thermal pre-treatment.

\begin{tabular}{llllll}
\hline Source & Sum of squares & DF & Mean square & F-value & P-value \\
\hline A:Temperature & 98.0 & 1 & 98.0 & 35.75 & 0.0003 \\
B:Time & 50.0 & 1 & 50.0 & 18.24 & 0.0027 \\
C:Flash & 2.0 & 1 & 2.0 & 0.73 & 0.4178 \\
AB & 4.0 & 1 & 4.0 & 1.46 & 0.2615 \\
BB & 4.0 & 1 & 4.0 & 1.46 & 0.2613 \\
BC & 1.0 & 1 & 1.0 & 0.36 & 0.5626 \\
Error total & 21.9 & 8 & 2.7 & & \\
Total (corr.) & 180.9 & 14 & & & \\
\hline
\end{tabular}

Critical value $\left(\mathrm{F}_{0}\right)$ for the F-test: $5.32\left(\mathrm{~F}_{0.05,1,8}\right)$.

Seongyeob et al., 2014; Xue et al., 2015).

It is also interesting to observe that same solubilisation is obtained for the thermal treatment at high temperature - short time, and lower temperature - higher time (i.e.: $36 \% \mathrm{SB}$ at $170{ }^{\circ} \mathrm{C}-10 \mathrm{~min}$ and $140{ }^{\circ} \mathrm{C}-50 \mathrm{~min}$ ).

\subsection{Effect of $T H$ variables on the methane production}

The methane production was compared with the production obtained for the control of untreated sludge $\left(220 \mathrm{ml} \mathrm{CH} 4 / \mathrm{VS}_{\mathrm{fed}}\right)$ following the same evaluation methodology followed for the solubilisation: separate influence of variables, analysis of variance and response plots.

Fig. 4 shows that methane production is affected by all the factors experimentally quantified. In contrast to the results previously obtained for solubilisation, the trend is not linear for the ranges evaluated, and an optimum is obtained for each factor analyzed. First, when temperature increased from $130^{\circ} \mathrm{C}$ to $160^{\circ} \mathrm{C}$, the methane production increased deeper and later started to decrease. The same trend was obtained for the treatment time, exhibiting a decrease in the methane enhancement for values higher than $30 \mathrm{~min}$. Finally, a single sudden flash is the optimum decompression alternative.

Results of the variance analysis are presented in Table 3, exhibiting that coefficients for the linear effect of the temperature (A) and for the squared effects of the temperature (AA) and flash (CC) on methane production are statistically significant model terms at $95 \%$ confidence level $(p<0.05)$. Although not statistically significant, the linear effect of the flash (C) on methane production appears to be more valid than the linear effect of the time (B).

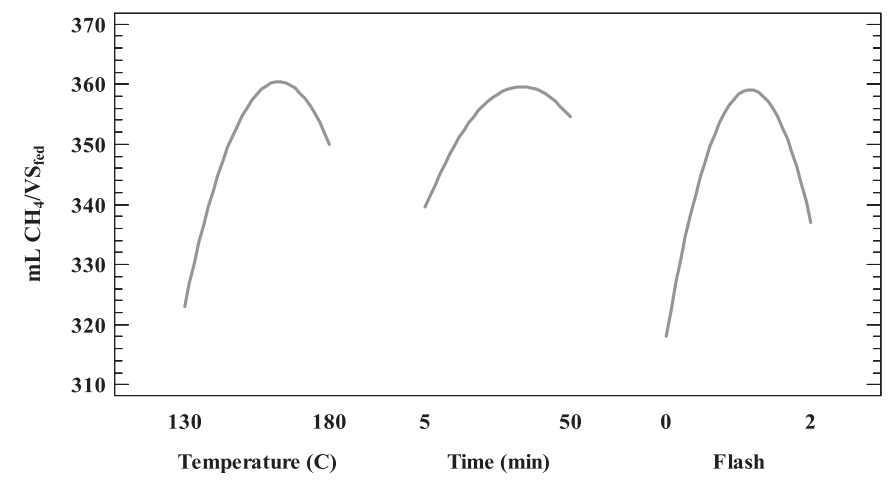

Fig. 4. Influence of the factors evaluated on methane production.

Based on the ANOVA results, Equation (7) was obtained using Equation (5) to fit the experimental data of the methane production, being $\mathrm{X}_{1}$ the heating temperature, $\mathrm{X}_{2}$ the hydrolysis time and $\mathrm{X}_{3}$ the decompression mode.

$$
\begin{aligned}
\mathrm{CH}_{4}\left(\mathrm{~mL} / \mathrm{VS}_{\text {fed }}\right)= & -629.364+11.3487 * X_{1}+1.56008 * X_{2} \\
& +71.0833 * X_{3}-0.0348667 * X_{1}^{2} \\
& -0.0223045 * X_{2}^{2}-30.7917 * X_{3}^{2}
\end{aligned}
$$

The model was considered valid with the same criteria as the previous model for WAS solubilisation, being $r^{2}=0.851$ in this case. The three dimensional response surface plot and two dimensional contour plot shown in Fig. 5 describe the interaction between

Table 3

ANOVA table for the methane production of WAS after thermal pre-treatment.

\begin{tabular}{llllll}
\hline Source & Sum of squares & DF & Mean square & F-value & P-value \\
\hline A:Temperature & 1458 & 1 & 1458 & 8.61 & 0.0189 \\
B:Time & 450 & 1 & 450 & 2.66 & 0.1417 \\
C:Flash & 722 & 1 & 722 & 4.26 & 0.0728 \\
AA & 1753 & 1 & 1753 & 10.35 & 0.0123 \\
BB & 470 & 1 & 470 & 2.78 & 0.1340 \\
CC & 3500 & 1 & 3500 & 20.67 & 0.0019 \\
Error total & 1354 & 8 & 169 & & \\
Total (corr.) & 9098 & 14 & & & \\
\hline
\end{tabular}

Critical value $\left(\mathrm{F}_{0}\right)$ for the F-test: $5.32\left(\mathrm{~F}_{0.05,1,8}\right)$.
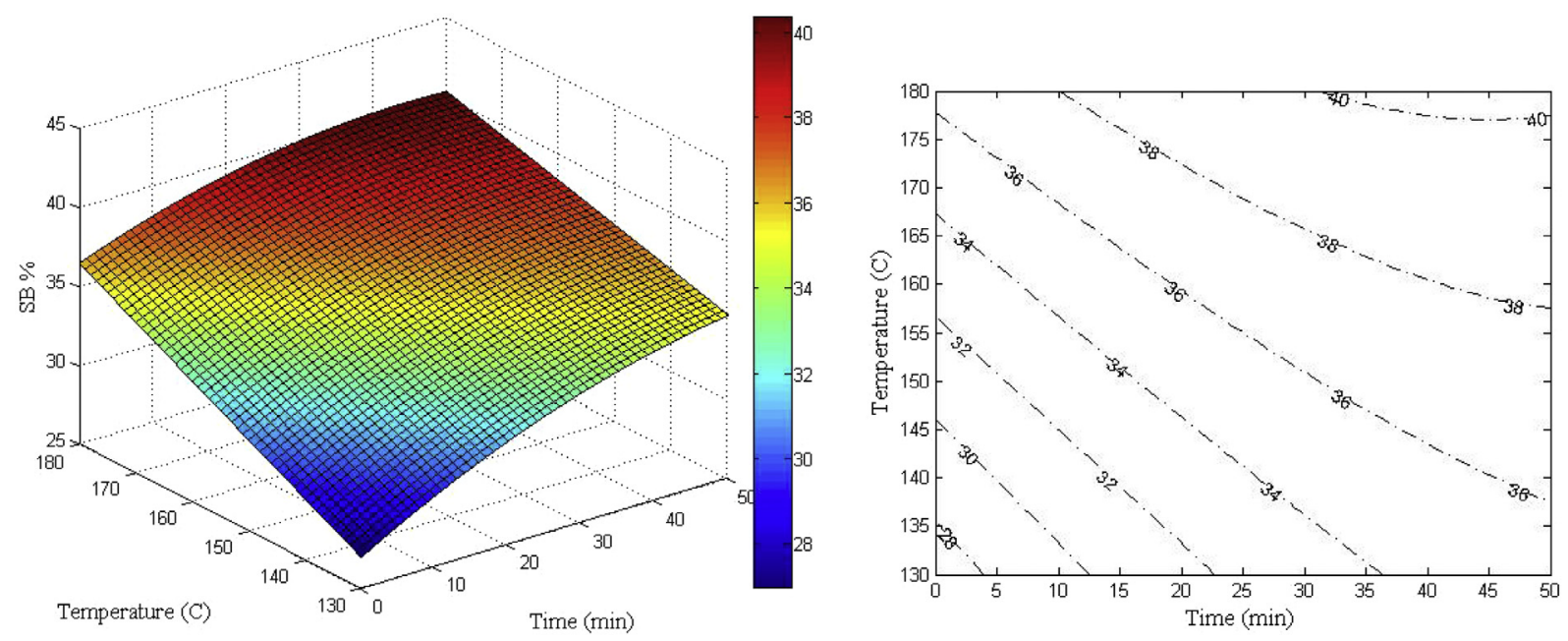

Fig. 3. Response surface plot and contour plot showing the effects of temperature and time on WAS solubilisation. 

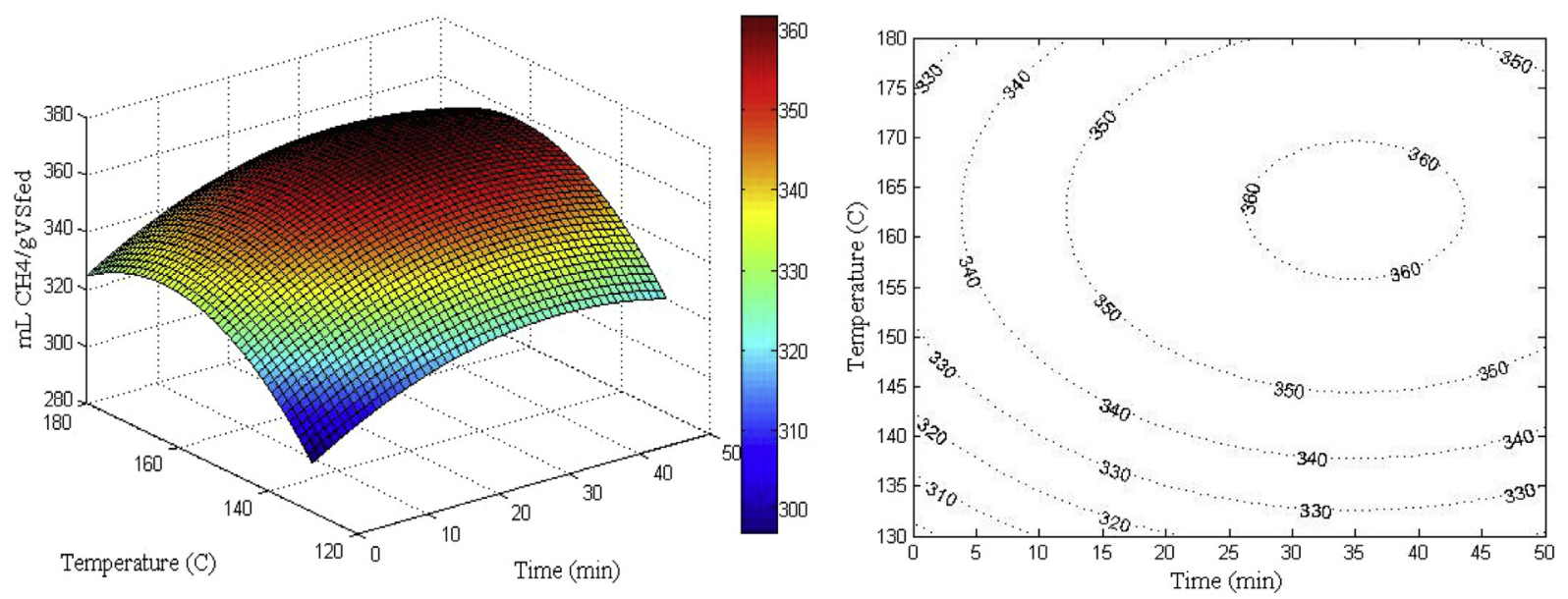

Fig. 5. Response surface plot and contour plot showing the effects of temperature and time on methane production.

thermal pre-treatment temperature and time (again, sudden decompression in 1 flash was maintained constant). These graphs can be used to predict the optimum level of each factor to obtain the maximum expected value for methane production (Sarat Chandra et al., 2014).

Both plots exhibit a peak value for methane production, not corresponding to the maximum values of pre-treatment temperature and time, in contrast to the results obtained for solubilisation. In fact, the negative quadratic effect of temperature and time obtained in Equation (7) implies that, at high severity of the pretreatment, the methane production decreases (Bup Nde et al., 2012). These results agree with those studies reporting inhibition by formation of refractory compounds at high temperatures, generally stated over $170{ }^{\circ} \mathrm{C}$ (Bougrier et al., 2008; Dwyer et al, 2008). This formation of complex substances can also occur at lower temperatures for longer pre-treatment time (Elliot and Mahmood, 2012) as also obtained in Fig. 5.

Fig. 5 also reveals that thermal hydrolysis allows operating in a wide range of conditions reaching similar methane production. In our experiment the highest specific production of $360 \mathrm{mLCH}_{4} /$ $\mathrm{gVS}_{\text {fed }}$ can be obtained in the range $155-175{ }^{\circ} \mathrm{C}$ and $25-45 \mathrm{~min}$. This wide range clearly demonstrates that $\mathrm{TH}$ is a robust process which does not require a very strict and sophisticated operation control system. Expanding the working field until a specific methane productivity $5 \%$ lower than the maximum $\left(340 \mathrm{mLCH}_{4}\right.$ )
$\mathrm{gVS}_{\text {fed }}$ ), the operational range can be extended to $145-170{ }^{\circ} \mathrm{C}$ and 5-45 min, with corresponding savings in energy consumption.

Finally, other relevant technical aspect to be mentioned is that at higher pre-treatment temperature, shorter reaction time is required. The contour plot (Fig. 5) shows that it is possible to achieve identical specific productivity $\left(340-350 \mathrm{mLCH}_{4} / \mathrm{gVS}_{\text {fed }}\right)$ operating at $140-145{ }^{\circ} \mathrm{C}$ during $20-35 \mathrm{~min}$ or at $160-170{ }^{\circ} \mathrm{C}$ for 5-10 min. These results are consistent with those obtained by Zhang et al. (2014) and Hii et al. (2014).

\subsection{Optimization of the $\mathrm{TH}$ process}

The previous discussion of results for solubilisation and methane production show that the evaluated parameters (heating temperature, time and decompression mode) do not influence both responses in the same way, and the trend followed is not the same.

First, the experimental results presented in Table 1 show that solubilisation and methane enhancement do not present a link. For example, a solubilisation around $30 \%$ can lead to a methane increase in the range of $25-44 \%$, and $40 \%$ solubilisation is responsible for $42-55 \%$ methane increase.

Second, based on the models, the optimal values for solubilisation and methane production can be compared. A maximum methane production of $362 \mathrm{mLCH}_{4} / \mathrm{gVS}_{\text {fed }}$ was predicted at the optimum conditions $\left(163^{\circ} \mathrm{C}, 35 \mathrm{~min}\right.$ and $\left.1 \mathrm{flash}\right)$ while a maximum

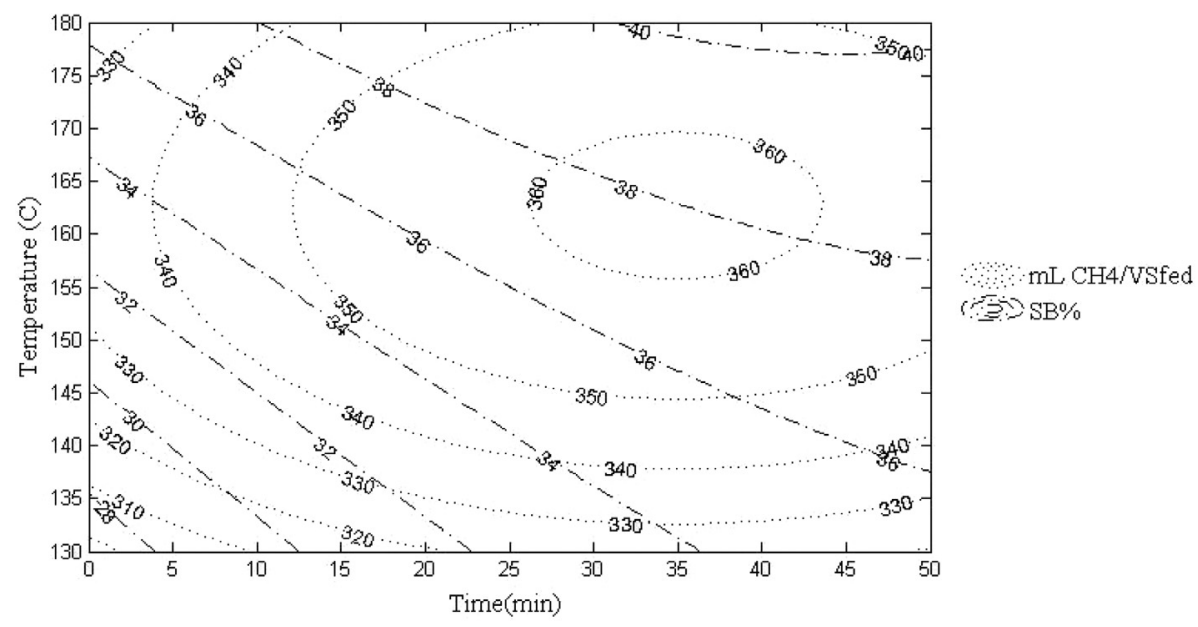

Fig. 6. Superimposed contour plots for methane production and solubilisation. 
solubilisation of $41 \%$ was achieved at higher operation conditions $\left(180^{\circ} \mathrm{C}, 49 \mathrm{~min}\right.$ and $1 \mathrm{flash}$ ). The increase of WAS solubilisation and parallel decrease on methane production at high pre-treatment temperature and long times, indicate that some soluble but nonbiodegradable compounds were produced during severe thermal pre-treatment. This is probably because of the production of melanoidins, as reported by many studies (Ariunbaatar et al., 2014; Xue et al., 2015).

Third, similar thermal hydrolysis efficiency (more than 50\%) could be obtained working at a wider process conditions: at 140-170 ${ }^{\circ} \mathrm{C}$ for $5-35 \mathrm{~min}$ respectively. These results are very interesting in order to minimize energy requirement of thermal hydrolysis process.

Finally, surface plots and contour plots for sludge solubilisation (Fig. 3) and methane production (Fig. 5) can be equated in order to compare the trend and optimal values for temperature and time. The contour plot curves of solubilisation and methane production were superimposed (Fig. 6) to exhibit that there is no joint optimum thermal hydrolysis conditions for both variables.

From Fig. 6 it can be clearly concluded that there is no common peak for both variables, meaning that thermal hydrolysis conditions for solubilisation do not correspond to maximum methane production. This conclusion approves that solubilisation is not a trustworthy parameter for thermal hydrolysis productivity.

The translation of these results from a practical point of view is that the solubilisation measurement is not a suitable prediction parameter to quantify thermal hydrolysis efficiency. The increase in solubilisation obtained at high intensity pre-treatment is not always associated with increase in methane production.

\section{Conclusions}

Thermal hydrolysis of waste activated sludge is a robust pretreatment, leading to significant improvements in anaerobic digestion (up to $70 \%$ increases in methane production) operating in a wide range of experimental conditions. The key mechanisms and variables of the process are: heating (temperature and time) and decompression mechanism (slow or steam explosion). The statistical analysis performed exhibited that efficiency of the pretreatment is mainly influenced by temperature, while the reaction time has a lower incidence. And there is no direct correlation between the solubilisation achieved and the methane production increase. While solubility increases sharply at high intensity pretreatment (high temperature and long times), the methane production presents an optimum, that when exceeded, recalcitrant compounds may appear. Consequently, it is not recommended the use of solubilisation as a prediction parameter to quantify pretreatment efficiency, since it is not related to methane production.

An increase in methane production exceeding $50 \%$ was obtained by a steam explosion pre-treatment performed in the range $140-170{ }^{\circ} \mathrm{C}$ heating and 5-35 min. Therefore, an exhaustive control of thermal pre-treatment conditions appears to be not necessary, while the selection of operation conditions play a key role on the process economics.

\section{References}

Angelidaki, I., Alves, M., Bolzonella, D., Borzacconi, L., Campos, J.L., Guwy, A.J. Kalyuzhnyi, S., Jenicek, P., Van Lier, J.B., 2009. Defining the biomethane potential (BMP) of solid organic wastes and energy crops: a proposed protocol for batch assays. Water Sci. Technol. 59 (5), 927-934.

Appels, L., Degreve, J., Van der Bruggen, B., Van Impe, J., Dewil, R., 2010. Influence of low temperature thermal pre-treatment on sludge solubilisation, heavy metal reléase and anaerobic digestion. Bioresour. Technol. 101, 5743-5748.

Appels, L., Baeyens, J., Degreve, J., Dewil, R., 2008. Principles and potential of the anaerobic digestion of waste activated sludge. Prog. Energy Combust. Sci. 34, 755-781.

Ariunbaatar, J., Panico, A., Esposito, G., Pirozzi, F., Lens, P.N.L., 2014. Pretreatment methods to enhance anaerobic digestion of organic solid. Appl. Energy 123, $143-156$.

Benito-Roman, O., Alonso, E., Cocero, M.J., 2013. Ultrasound-assisted extraction of $\beta$ glucans from barley. LWT - Food Sci. Technol. 50, 57-63.

Bougrier, C., Delgenès, J.P., Carrère, H., 2008. Effects of thermal treatments on five different waste activated sludge samples solubilisation, physical properties and anaerobic digestion. Chem. Eng. J. 139 (2), 236-244.

Bup Nde, D., Abi, C.F., Tenin, D., Kapseu, C., Tchiegang, C., 2012. Optimisation of the cooking process of sheanut kernels (Vitellaria paradoxa Gaertn.) using the doehlert experimental design. Food Bioprocess Technol. 5, 108-117.

Cano, R., Pérez-Elvira, S.I., Fdz-Polanco, F., 2015. Energy feasibility study of sludge pretreatments: a review. Appl. Energy 149, 176-185.

Dwyer, J., Starrenburg, D., Tait, S., Barr, K., Batstone, D.J., Lant, P., 2008. Decreasing activated sludge thermal hydrolysis temperature reduces product colour, without decreasing degradability. Water Res. 42 (18), 4699-4704.

Elliot, A., Mahmood, T., 2012. Comparison of mechanical pretreatment methods for the enhancement of anaerobic digestion of pulp paper waste. Water Sci. Technol. 84, 497-505.

Fernández-Polanco, F., Velázquez, R., Pérez-Elvira, S.I., Casas, C., Del Barrio, D. Cantero, F.J., Fernández-Polanco, M., Rodríguez, P., Panizo, L., Serrat, J., Rouge, P., 2008. Continuous thermal hydrolysis and energy integration in sludge anaerobic digestion plants. Water Sci. Technol. 57 (8), 1221-1226.

Garrido, J.M., Fdz-Polanco, M., Fdz-Polanco, F., 2013. Working with energy and mass balances: a conceptual framework to understand the limits of municipal wastewater treatment. Water Sci. Technol. 67, 2094-2301.

Hii, K., Baroutina, S., Parthasarathy, R., Gapes, D.J., Eshtiaghi, N., 2014. A review of wet air oxidation and thermal hydrolysis technologies. Bioresour. Technol. 155, 289-299.

Jung, K.W., Hwang, M.J., Cha, M.J., Ahn, K.H., 2015. Application and optimization of electric field-assisted ultrasonication for disintegration of waste activated sludge using response surface methodology with a Box-Behnken design. Ultrason. Sonochem. 22, 437-445.

Kim, D., Lee, K., Park, K.Y., 2015. Enhancement of biogas production from anaerobic digestion of waste activated sludge by hydrothermal pretreatment. Int. Biodeterior. Biodegrad. 101, 42-46.

Pérez-Elvira, S.I., Fdz-Polanco, F., Fdz-Polanco, M., Rodríguez, P., Rougé, P., 2008. Hydrothermal multivariable approach: full-scale feasibility study. Electron. J. Biotechnol. 11, 7-8.

Sarat Chandra, T., Suvidha, G., Mukherji, S., Chauhan, V.S., Vidyashankar, S., Krishnamurthi, K., Sarada, R., Mudliar, S.N., 2014. Statistical optimization of thermal pretreatment conditions for enhanced biomethane production from defatted algal biomass. Bioresour. Technol. 162, 157-165.

Seongyeob, J., Sukyoung, J., SoonWoong, C., 2014. Enhancement of anaerobic biodegradability and solubilization by thermal pre-treatment of waste activated sludge. New Renew. Energy 10, 20-29.

Xue, Y., Liu, H., Chen, S., Dichtl, N., Dai, X., Li, N., 2015. Effects of thermal hydrolysis on organic matter solubilisation and anaerobic digestion of high solid sludge. Chem. Eng. J. 264, 174-180.

Zhang, L., Zhang, Y., Zhang, Q., Verpoort, F., Cheng, W., Caoi, L., Li, M., 2014. Sludge gas production capabilities under various operational conditions of the sludge thermal hydrolysis pretreatment process. J. Energy Inst. 87, 121-126.

Zhang, S., Guo, H., Du, L., Liang, J., Lu, X., Li, N., Zhang, K., 2015. Influence of $\mathrm{NaOH}$ and thermal pretreatment on dewatered activated sludge solubilisation and subsequent anaerobic digestion: focused on high-solid state. Bioresour. Technol. 185, 171-177. 
Thermal hydrolysis of sludge over a limiting temperature. Effect on prediction parameters 



\title{
Thermal hydrolysis of sludge over a limiting temperature. Effect on prediction parameters
}

\author{
I. Sapkaite, F. Fdz-Polanco, S.I. Pérez-Elvira*, \\ Department of Chemical Engineering and Environmental Technology. University of Valladolid. Spain. \\ (E-mail*: sarape@iq.uva.es)
}

\begin{abstract}
Anaerobic digestion has today become a promising method for sludge treatment and thermal hydrolysis (TH) is an important pre-treatment method to improve the efficiency of the process, especially for the digestion of waste activated sludge (WAS). The effect of exceeding the limiting thermal hydrolysis temperature and the influence of reaction time were investigated in this study. Biochemical methane potential tests (BMP) were set up to evaluate the methane production. Only pre-treatment at $150{ }^{\circ} \mathrm{C}$ presented higher methane production up to $30 \%$ compared to the untreated sample. Thermal hydrolysis at $200{ }^{\circ} \mathrm{C}$ showed evident changes in TH behaviour and efficiency. The application of higher severity factor (T-t) led to less methane production that is reflected in the decline on biodegradability and degradation factor. It was also determined that it is not reliable to use of solubilisation as prediction parameter to quantify $\mathrm{TH}$ efficiency since it is not related to biodegradability or methane production. At both, moderate or higher than the limit $\mathrm{TH}$ temperatures, reaction time had a negligible effect on the parameters studied.
\end{abstract}

\section{Keywords}

BMP; severity factor; solubilisation; thermal hydrolysis; waste activated sludge

\section{INTRODUCTION}

Increased methane production from anaerobic digestion $(\mathrm{AD})$ is the primary goal of thermal pretreatment processes in sludge treatment today, because not only resources in sludge are being recovered, but also the energy, which can be produced from the increased methane, can be used to make the thermal pre-treatment process energetically neutral. This means that identifying the factors which affect methane yield through thermal pre-treatment is of great interest.

Thermal hydrolysis $(\mathrm{TH})$ process is the most widespread high pressure steam pre-treatment process used in Europe for sludge disintegration where sludge is heated to about $170{ }^{\circ} \mathrm{C}$ and 7 bars for about 30 minutes (Shana et al. 2013). Heat applied during thermal pre-treatment disrupts the chemical bonds of the cell wall and membrane, thus solubilises the cell components and makes the sludge more accessible to the anaerobic microorganisms (Appels et al. 2008). This fact improves the overall digestion process velocity and the degree of sludge degradation thus reducing anaerobic digester retention time, final quantity of residual sludge and increasing methane production rates. This is particularly effective when treating waste activated sludge that contains bacterial cells, which are not easily biodegradable (Hii et al. 2014).

There is a statement saying that the higher the temperature, the more efficient the treatment (Prorot et al. 2011). To the same, a linear relation between solubilisation and biodegradation has been shown (Dwyer et al. 2008; Perez-Elvira et al. 2015). However, that TH efficiency could be expressed different (e.g. increased solubility, dewaterability, degradation, biogas production and so on) depending on the objective in every research study. Moreover, most of the studies are performed in a narrow experimental conditions range (in most cases process temperature $\leq 170{ }^{\circ} \mathrm{C}$ ) thus resulting in the inconsistent or contrary conclusions. So the doubt of the physical and biological process behaviour applying high $\mathrm{TH}$ temperature (e.g. $200^{\circ} \mathrm{C}$ ) still persists. Only some authors have already reported that exceeding a limit temperature $\left(170^{\circ} \mathrm{C}\right) \mathrm{TH}$ behaviour and efficiency totally changes (Bougrier et al. 2006; Ariunbaatar et al. 2014). 
Although TH effect depends on the substrate nature and temperature range (Ariunbaatar et al. 2014) uncertainty on the effect of reaction time still remains. Perhaps some conditions combining low-high temperature and short-long time, however, could show similar and notable effect on the final results.

This study aims to experimentally evaluate the effect of exceeding this limiting temperature and verify the influence of reaction time. Simultaneously the study searches to verify if the increase in solubilisation and severity factor can be established as control parameters by keeping or not direct relationship with prediction parameters.

\section{MATERIALS AND METHODS}

\section{Sludge sampling}

To carry out the study, a single sample of concentrated waste activated sludge (WAS) was taken from the municipal waste water treatment plant of Valladolid (Spain). According to Pérez-Elvira et al. (2008), the sludge was thickened to $14 \%$ TS (73\% VS) to perform the research with concentrated sludge, that is the real operation in pre-treatment units.

The anaerobic inoculum for the biochemical methane potential (BMP) tests was sampled from the anaerobic digester in the WWTP treating mixed sludge, and pre-incubated for 3 days at $35^{\circ} \mathrm{C}$ in a thermostated chamber prior to use in order to activate the microorganisms and to deplete most of the residual organic matter.

\section{Thermal hydrolysis pre-treatment, operating variables and experimental set-up}

The experiment was carried out in a lab-scale thermal pre-treatment plant (Figure 1), which consists of a $1.5 \mathrm{~L}$ reactor heated with the live steam from a boiler, and connected to an atmospheric flash tank $(6 \mathrm{~L})$ by a decompression valve that opens in a steam-explosion effect (sudden decompression). Two variables were evaluated: temperature $\left(150^{\circ}, 200^{\circ} \mathrm{C}\right)$ and time $(5 ; 30$ and 50 minutes). The operation is batch and controlled manually.

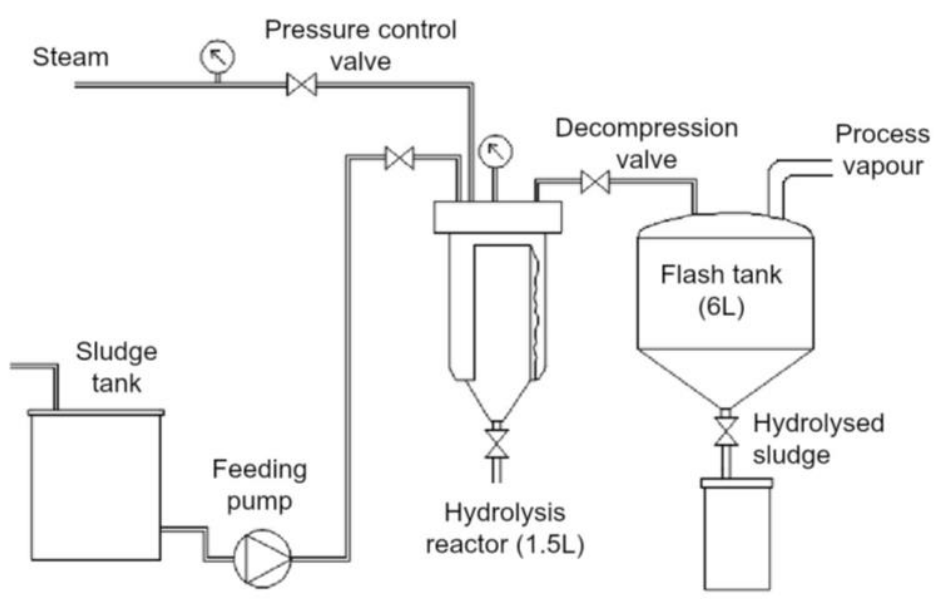

Figure 1. Thermal pre-treatment system.

\section{Batch anaerobic biodegradability tests}

BMP tests were performed in triplicate assays using $300 \mathrm{~mL}$ serum bottles, filled with $100 \mathrm{ml}$ of a mixture of anaerobic inoculum and the corresponding substrate at a substrate to inoculum ratio (SIR) of $0.5 \mathrm{~g} / \mathrm{g}$ on volatile solids (VS) basis. In this test, micronutrients and macronutrients were added ensuring no nutritional limitation for optimal function of anaerobic microorganisms. Moreover, $\mathrm{NaHCO}_{3}$ and $\mathrm{Na}_{2} \mathrm{~S}$ were added to provide buffer capacity and avoid aerobic conditions respectively. 
The methodology used was the one suggested by Angelidaki et al. (2009).

The bottles were incubated in a thermostated chamber at $35^{\circ} \mathrm{C}$ in an orbital shaker at $150 \mathrm{rpm} / \mathrm{min}$. Methane production in the BMP tests was determined by periodic measurements of pressure and biogas composition in the headspace of the bottles. Blanks containing only anaerobic inoculum were mounted to determine the endogenous methane production from the remaining organic matter that comes with the inoculum, which was subtracted from the total methane production in the BMP tests to obtain the real methane production of the substrate. The experimental values obtained are always referred to average values, with the corresponding standard deviation.

\section{Analytical methods and performance parameters}

Total solids (TS) and volatile solids (VS) concentrations were determined according to Standard Methods, 21st edition (APHA, 2005). The total COD was obtained by a direct COD analysis. The soluble phase for SCOD was achieved by centrifugation at $5000 \mathrm{rpm}$ for 10 minutes. The pressure in the headspace of the BMP bottles was measured with a pressure sensor PN 5007 (IFM, Germany), and biogas composition was determined using a gas chromatograph coupled to a thermal conductivity detector (Varian CP-3800, USA).

Table 1 summarizes the target parameters calculated.

Table 1. Parameters determined for the estimation

\begin{tabular}{|c|c|c|c|}
\hline Parameter & Symbol & Units & Equation \\
\hline Severity factor & $\log R_{0}$ & -- & $\log R_{0}=\log \left(t \cdot \exp \left(\frac{T-100}{14.75}\right)\right)$ \\
\hline $\begin{array}{l}\text { Solubilization } \\
\text { factor }\end{array}$ & SF & $\%$ & $\% S F=\frac{(\mathrm{SCOD} / \mathrm{TCOD})_{T H}-(S C O D / T C O D)_{0}}{((T C O D-S C O D) / T C O D)_{0}} \times 100$ \\
\hline $\begin{array}{l}\text { Methane } \\
\text { potential }\end{array}$ & $\mathrm{CH}_{4}$ & $\begin{array}{c}\mathrm{mL} \mathrm{CH}_{4} / g \\
\mathrm{VS}_{\mathrm{fed}}\end{array}$ & $\mathrm{CH}_{4}=\frac{m L C H_{4}}{g V S_{\text {fed }}}$ at standard conditions $\left(0^{\circ} \mathrm{C}, 1 \mathrm{~atm}\right)$ \\
\hline Biodegradability & $\mathrm{BD}$ & $\%$ & $\% B D=\frac{m L C H_{4} / g V S_{f e d}}{\left(350 m L C H_{4} / g T C O D_{r e m}\right) \cdot(g T C O D / g V S)} \times 100$ \\
\hline $\begin{array}{l}\text { Degradation } \\
\text { factor }\end{array}$ & DF & $\%$ & 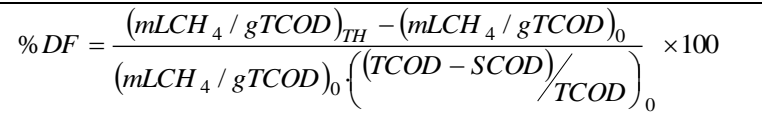 \\
\hline
\end{tabular}

It may be noted that both solubilisation and degradation factors (SF and DF) are calculated with respect to the particulate fraction of the $\mathrm{COD}$, in contrast to most of the references that express these parameters with respect to the total COD. These proposed expressions are more accurate as the particulate matter is the potentially hydrolysable fraction during the pre-treatment. And sludge biodegradability (BD) was calculated as the ratio of the experimental ( $\left.\mathrm{mL} \mathrm{CH}_{4} / \mathrm{gCOD}\right)$ to the theoretical methane production $\left(350 \mathrm{~mL} \mathrm{CH}_{4} / \mathrm{gCOD}_{\text {removed }}\right)$.

\section{Parameter fitting}

The Modified Gompertz (MG) equation (Equation [1]) was used to fine-tune the experimental data from BMP tests to theoretical equation in order to estimate kinetic parameters with a certain degree of confidence. The parameters from the MG equation are mainly used for comparison purpose since it is a model that is being widely employed for anaerobic batch test assessment (BoladoRodriguez et al. 2016; Kafle and Chen 2016; Lobo Baeta et al. 2016). 


$$
B=P \times \exp \left\{-\exp \left[\frac{R_{m} \times e}{P}(\lambda-t)+1\right]\right\}
$$

where $\mathrm{B}$ is the calculated methane production ( $\mathrm{mL} \mathrm{CH} / \mathrm{gVS}$ ) for each time $\mathrm{t}$; $\mathrm{P}$ is the maximum methane production parameter expressed as $\mathrm{mL} \mathrm{CH} / \mathrm{gVS} ; \mathrm{R}_{\mathrm{m}}$ is the maximum methane production rate $(\mathrm{mL} \mathrm{CH} / \mathrm{gVS} / \mathrm{d})$ and $\lambda$ is a lag-phase parameter in days $(\mathrm{d})$. The correlation factor $\left(\mathrm{R}^{2}\right)$ was also calculated to assess the accuracy of each model with respect to the experimental data.

\section{RESULTS AND DISCUSSION}

\section{Biodegradability tests (BMP)}

Figure 2 shows the anaerobic digestion curves achieved in the BMP tests.

a)

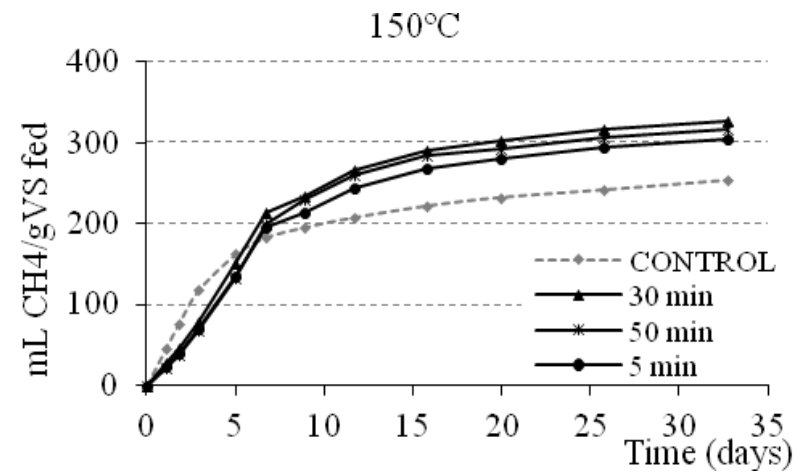

b)

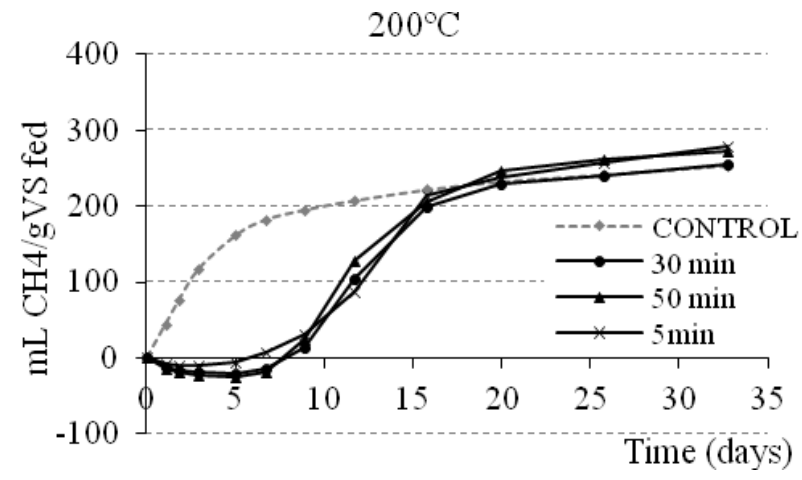

Figure 2. Methane production curves after BMP tests of thermally pre-treated waste activated sludge at $150^{\circ} \mathrm{C}$ (a) and $200^{\circ} \mathrm{C}(\mathrm{b})$.

Starting from the temperature, Figure 2 shows a clear effect - at $150^{\circ} \mathrm{C} \mathrm{TH}$ presents higher methane production (30\%) compared to the control (untreated sample), however at $200^{\circ} \mathrm{C}$ methane production remains almost constant. In addition a very marked lag phase, larger than 8 days, also appears at higher temperatures confirming evident changes in TH behaviour and efficiency.

From a time point of view - noticeable effect of $\mathrm{TH}$ reaction time has not been noticed at both temperatures investigated which is consistent with most reports indicating that $\mathrm{TH}$ time has no significant influence on biogas production (Donoso-Bravo et al. 2011; Pérez-Elvira et al. 2015).

\section{Relationship between pre-treatment conditions and efficiency parameters}

For a precise improvement determination, Table 2 displays efficiency parameters calculated for the different operating conditions. 
Table 2. Experimental-set-up and performance parameters

\begin{tabular}{|c|c|c|c|c|c|c|c|c|c|c|}
\hline & \multicolumn{4}{|c|}{ THERMAL HYDROLYSIS } & \multicolumn{3}{|c|}{ ANAEROBIC DIGESTION } & \multicolumn{3}{|c|}{ KINETIC PARAMETERS } \\
\hline & $\mathrm{T}$ & $\mathrm{t}$ & & $\% S F$ & $\mathrm{CH}_{4}$ & $\% B D$ & $\% D F$ & $R_{m}$ & $\lambda$ & \\
\hline & $\left({ }^{\circ} \mathrm{C}\right)$ & $(\min )$ & $\log \mathrm{R}_{0}$ & $(\%)$ & $(\mathrm{mL} / \mathrm{gVS})$ & $(\%)$ & $(\%)$ & $\begin{array}{c}(\mathrm{mL} \\
\mathrm{CH} 4 / \mathrm{gVS} / \mathrm{d})\end{array}$ & (d) & $R^{2}$ \\
\hline CONTROL & --- & --- & 0 & $0 \%$ & 254 & $49 \%$ & $0 \%$ & 34.8 & 0 & 0.971 \\
\hline TH-1 & 150 & 5 & 2.17 & $23 \%$ & 304 & $61 \%$ & $28 \%$ & 30.2 & 0.6 & 0.993 \\
\hline TH-2 & 150 & 30 & 2.95 & $36 \%$ & 327 & $66 \%$ & $41 \%$ & 33.1 & 0.5 & 0.993 \\
\hline TH-3 & 150 & 50 & 3.17 & $39 \%$ & 316 & $63 \%$ & $34 \%$ & 32.6 & 0.9 & 0.995 \\
\hline TH-4 & 200 & 5 & 3.64 & $47 \%$ & 278 & $57 \%$ & $20 \%$ & 30.4 & 8.5 & 0.995 \\
\hline TH-5 & 200 & 30 & 4.42 & $47 \%$ & 254 & $58 \%$ & $22 \%$ & 34.3 & 8.8 & 0.996 \\
\hline TH-6 & 200 & 50 & 4.64 & $48 \%$ & 273 & $52 \%$ & $8 \%$ & 33.9 & 8.3 & 0.994 \\
\hline
\end{tabular}

Correlating the parameters with respect to the severity factor (Figure 3) an obvious effect of temperature is demosntrated.

a)

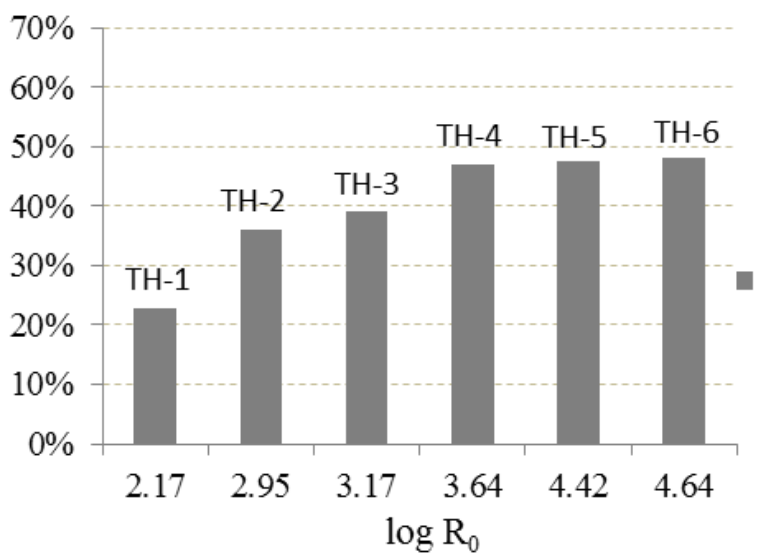

b)

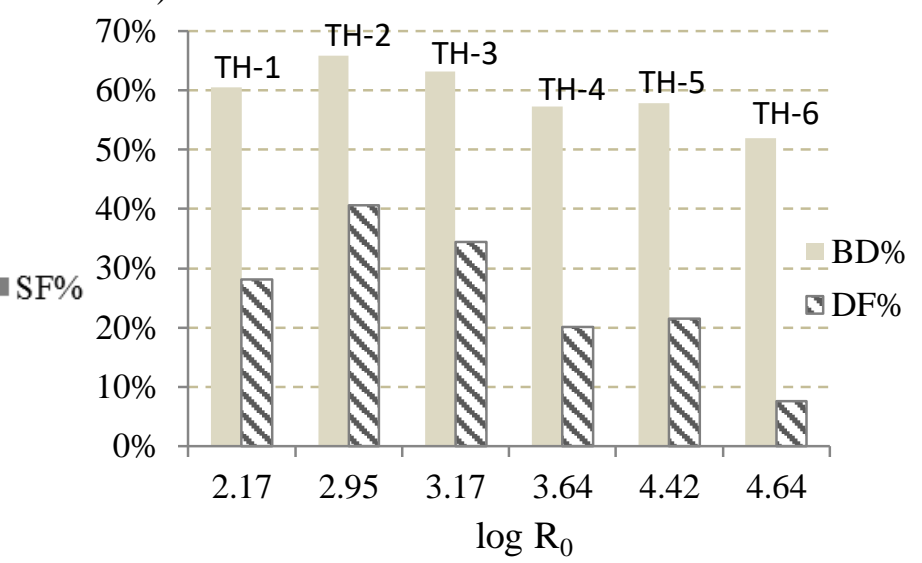

Figure 3. Relationship between performance parameters (SF, DF, BD) and severity factor $\left(\log \mathrm{R}_{0}\right)$.

Analyzing the influence of severity factor $\left(\log \mathrm{R}_{0}\right)$ on solubilisation $(\mathrm{SF})$, Figure $3 \mathrm{a}$ shows that solubility rises as the severity factor increases. This increase in solubility is more visible at low severity factor values, while for higher values a practically constant value of $47 \%$ is reached. These results are in agreement with those obtained by other authors confirming that solubilisation efficiency increase proportional to the temperature rise. Higher pre-treatment temperatures enhance extracellular polymeric substances (EPS) solubilisation and cell lysis (Seongyeob et al. 2014; Xue et al. 2015; Zhang et al. 2015). However, the Figure 3b shows that disintegration factor (DF) and biodegradability (BD), both of them related with methane production, exhibit a different behaviour. Both parameters involve presenting a maximum to severity values next to 3 (TH2\&TH3). The application of higher severity conditions leads to less methane production that is reflected in the decline of biodegradability. This negative effect occurs because thermal pre-treatment at high temperatures $\left(>170^{\circ} \mathrm{C}\right)$ leads to the formation of non-biodegradable recalcitrant compounds (in most TH cases melanoidins) (Nielsen et al. 2011; Ariunbaatar et al. 2014). These coloured recalcitrant compounds are produced by polymerisation of low molecular weight intermediates, such as carbohydrates and amino compounds at elevated temperature (Maillard reaction) (Dwyer et al. 2008). Thus, for higher temperature, biodegradability of sludge is no more improved and decreased (TH4-TH6) (Table 2) what means that not all organic matter solubilized was degraded to methane. To the same, the lag phase increased dramatically from $\lambda=0$ in the control up to $8.3-8.8$ days for pre-treatment at higher severity (TH4-TH6) (Table 2).

Comparing physical (solubilisation) and biological (biodegradation and degradation factor) 
behaviour obtained applying different severity conditions it can be stated that from a practical point of view solubilisation is not a suitable prediction parameter. The increase in solubilisation obtained at higher severity factors is not always associated with increased methane production. In this case, this result disclaim the statement saying that the higher the temperature, the more efficient the treatment (Prorot et al. 2011).

Although this study (Figure $3 \mathrm{a}$ and $3 \mathrm{~b}$ ) demonstrate that reaction time has a negligible effect on the studied parameters at both TH temperatures' and there is no symptom that a combinations of low temperature and long reaction time (TH3) or high temperature and short time (TH4) could show similar and notable effect on the final results (probably due to the narrow experimental range), Sapkaite et al. (2017) have founded that it is possible to achieve identical specific methane productivity $\left(340-350 \mathrm{mLCH}_{4} / \mathrm{gVS}_{\text {fed }}\right)$ operating $\mathrm{TH}$ at $140-145^{\circ} \mathrm{C}$ during $20-35$ minutes or at $160-170{ }^{\circ} \mathrm{C}$ for $5-10 \mathrm{~min}$.

Pre-treatment conditions at $150^{\circ} \mathrm{C}$ for $30 \mathrm{~min}$ (TH2) could be accepted like optimal from this experiment.

\section{CONCLUSIONS}

After experimental evaluation of $\mathrm{TH}$ at standard and exceeding the limit temperatures the main conclusion is that severity factor cannot be used in combination with solubility to prophecy $\mathrm{TH}$ productivity. Solubility rises while severity factor do, however biodegradability and degradation factor exhibit a maximum for severity factor next to 3 (at $150{ }^{\circ} \mathrm{C}$ for $30 \mathrm{~min}$ and at $150{ }^{\circ} \mathrm{C}$ for $50 \mathrm{~min}$ ). The application of higher severity leads to less methane production that is reflected in the decline on biodegradability and degradation factor, due to the formation of non biodegradable or recalcitrant compounds. Consequently, it is not recommended for use of solubilisation as prediction parameter to quantify TH efficiency since it is not related to biodegradability or methane production.

At both, moderate or higher than the limit TH temperatures, reaction time has a negligible effect on the parameters studied.

\section{REFERENCES}

Angelidaki, I., Alves, M., Bolzonella, D., Borzacconi, L., Campos, J.L., Guwy, A.J., Kalyuzhnyi, S., Jenicek, P., Van Lier, J.B. (2009). Defining the biomethane potential (BMP) of solid organic wastes and energy crops: a proposed protocol for batch assays. Water Science and Technology 59(5), 927-934.

APHA, AWWA, WPCP. (2005). Standard Methods for the Examination of Water and Wastewater, 21th ed. Washington DC.

Appels, L., Baeyens, J., Degreve, J., Dewil, R., 2008. Principles and potential of the anaerobic digestion of waste activated sludge. Progress in Energy and Combustion Science 34, 755-781.

Ariunbaatar, J., Panico, A., Esposito, G., Pirozzi, F., Lens, P. N. L., 2014. Pretreatment methods to enhance anaerobic digestion of organic solid. Applied Energy 123, 143-156.

Bolado-Rodríguez, S., Toquero, C., Martín-Juárez, J., Travaini, R., García-Encina, P.A. (2016). Effect of thermal, acid, alkaline and alkaline-peroxide pretreatments on the biochemical methane potential and kinetics of the anaerobic digestion of wheat straw and sugarcane bagasse. Bioresource Technology 201, 182-190.

Bougrier, C., Albasi, C., Delgenes, J. P., Carrere, H., 2006. Effect of ultrasonic, thermal and ozone pretreatments on waste activated sludge solubilization and anaerobic biodegradability. Chemical Engineering Processes 45, 711-718.

Donoso-Bravo, A., Pérez-Elvira, S. I., Aymerich, E., Fdz-Polanco, F., 2011. Assessment of the influence of the thermal pre-treatment time on the macromolecular composition and anaerobic biodegradability of sewage sludge. Bioresource Technology 102, 660-666.

Dwyer, J., Starrenburg, D., Tait, S., Barr, K., Batstone, D.J., Lant, P. (2008). Decreasing activated sludge thermal hydrolysis temperature reduces product colour, without decreasing degradability. Water Research 42, 4699-4709. 
Hii, K., Baroutina, S., Parthasarathy, R., Gapes, D. J., Eshtiaghi, N., 2014. A review of wet air oxidation and thermal hydrolysis technologies. Bioresource Technology 155, 289-299.

Kafle, G.K., Chen, L. (2016). Comparison on batch anaerobic digestion of five different livestock manures and prediction of biochemical methane potential (BMP) using different statistical models. Waste Management 48, 492-502.

Lobo Baeta, B.E., Sousa Lima, D.R., Herrera Adarme, O.F., Alves Gurgel, L.V., de Aquino, S.F. (2016). Optimization of sugarcane bagasse autohydrolysis for methane production from hemicellulose hydrolyzates in a biorefinery concept. Bioresource Technology 200, 137-146.

Nielsen, H.B., Thygesen, A., Thomsen, A.B., Schmidt, J.E. (2011). Anaerobic digestion of waste activated sludge - comparison of thermal pre-treatments with thermal inter-stage treatments. Journal of Chemical Technology and Biotechnology 86, 238-245.

Pérez-Elvira, S. I., Fdz-Polanco, F., Fdz-Polanco, M., Rodríguez, P., Rougé, P. (2008). Hydrothermal multivariable approach: Full-scale feasibility study. Electronic Journal of Biotechnology 11, 7-8.

Pérez-Elvira, S. I.; Sapkaite, I.; Fernández-Polanco, F. (2015). Evaluation of thermal steam-explosion key operation factors to optimize biogas production from biological sludge. Water Science and Technology 72.6, 937-945.

Prorot, A., Laurent, J., Dagot, C., Leprat, P. (2011). Sludge disintegration during heat treatment at low temperature: A better understanding of involved mechanisms with a multiparametric approach. Biochemical Engineering Journal 54, 178-184.

Sapkaite, I., Barrado, E., Fdz-Polanco, F., Pérez-Elvira, S. I. (2017). Optimization of a thermal hydrolysis process for sludge pre-treatment. Journal of Environmental Management 191, 25-30.

Seongyeob, J., Sukyoung, J., SoonWoong, C. (2014). Enhancement of Anaerobic Biodegradability and Solubilization by Thermal Pre-treatment of Waste Activated Sludge. New and Renewable Energy 10, 2029.

Shana, A., Ouki S., Asaadi, M., Mancini, G., 2013. The impact of intermediate thermal hydrolysis on the degradation kinetics of carbohydrates in sewage sludge. Bioresource Technology 137, 239-244.

Xue, Y., Liu, H., Chen, S., Dichtl, N., Dai, X., Li, N. (2015) Effects of thermal hydrolysis on organic matter solubilisation and anaerobic digestion of high solid sludge. Chemical Engineering Journal 264, 174-180.

Zhang, S., Guo, H., Du, L., Liang, J., Lu, X., Li, N., Zhang, K. (2015). Influence of NaOH and thermal pretreatment on dewatered activated sludge solubilisation and subsequent anaerobic digestion: Focused on high-solid state. Bioresourse Technology 185, 171-177. 


\section{CHAPTER 7}

Pérez-Elvira S.I, Sapkaite I, Fdz-Polanco F (2016)

Brazilian Journal of Chemical Engineering 33 (4), 699-704

Separate digestion of liquid and solid fractions of thermally pretreated secondary sludge. Assessment and global evaluation 



\title{
Brazilian Journal \\ of Chemical \\ Engineering
}

ISSN 0104-6632

\section{SEPARATE DIGESTION OF LIQUID AND SOLID FRACTIONS OF THERMALLY PRETREATED SECONDARY SLUDGE. ASSESSMENT AND GLOBAL EVALUATION}

\author{
S. I. Pérez-Elvira*, I. Sapkaite and F. Fdz-Polanco \\ Department of Chemical Engineering and Environmental Technology, \\ University of Valladolid, C/ Dr. Mergelina s/n, 47011, Valladolid, Spain. \\ Phone: + 34 983.18.4934; Fax: + 34 983.18.4865 \\ E-mail: sarape@iq.uva.es
}

(Submitted: April 30, 2015 ; Revised: July 8, 2015 ; Accepted: July 13, 2015)

\begin{abstract}
The fractioning into separate liquid and solid fractions obtained by centrifugation of thickened fresh and thermally pretreated $\left(170{ }^{\circ} \mathrm{C}, 50\right.$ minutes $)$ secondary sludge showed that $30 \%$ of the particulate organic matter was released during the pretreatment, correspondingly increasing the methane production of the particulate matter by $30 \%$ (from 259 to $329 \mathrm{~mL} \mathrm{CH} / \mathrm{g} \mathrm{VS}_{\mathrm{fed}}$ ). The responsible of this enhancement was the liquid fraction, as the biodegradability of the solid fraction remained constant after the pretreatment. Mass balances showed that $34 \%$ of the VS were released to the liquid fraction, generating nearly $50 \%$ of the total methane produced, with much faster kinetics compared to the solid fraction. These results support the hypothesis of a separate liquid-solid digestion of thermally pretreated sludge, which would result in decreasing the digestion volume to half while duplicating the methane productivity per kilogram of sludge fed to digestion.

Keywords: Anaerobic digestion; BMP; Liquid/solid fractions; Secondary sludge; Thermal hydrolysis.
\end{abstract}

\section{INTRODUCTION}

Owing to environmental, economic, social and legal factors, there is a great interest in the reduction of sludge production volume, as well as resource recovery options. Anaerobic digestion is a well-proven route, combining sludge removal with energy production. However, waste activated sludge (WAS) is biological (Neyens and Baeyens, 2003) and, therefore, anaerobic digestion is unable to remove a high fraction of the organic matter and unable to reduce significantly its final volume.

Hydrolysis being the rate limiting step for the biological degradation of WAS (Li and Noike, 1992; Shimizu et al., 1993), the introduction of a thermal hydrolysis pretreatment has proven to be a very interesting option (Kepp et al., 1999; Bougrier et al.,
2008; Carrère et al., 2010), currently implemented full-scale (mainly Cambi ${ }^{\circledR}$ and Biothelys $\left.{ }^{\circledR}\right)$.

On the other hand, taking into account the different kinetics of hydrolytic, acidogenic and methanogenic stages, and the solubilisation reported for the organic matter after a thermal pretreatment (Carrère et al., 2008), it is reasonable to consider the possibility of a separate digestion of solid and liquid fractions. This scenario has been proposed and studied for slurries coming from pig and dairy installation (Nozhevnikova et al., 1999; Rico et al, 2007; Sutaryo et al., 2013), but is still unexplored in the case of sludge.

The hypothesis that supports this research is that a thermal hydrolysis pre-treatment improves the biodegradabilty and kinetics of sludge, but the resulting solid and liquid phases are probably radically

*To whom correspondence should be addressed

This is an extended version of the work presented at the XI Latin American Symposium on Anaerobic Digestion (DAAL-2014), Havana, Cuba. 
different and can be considered separately in order to conceive a novel and optimized global digestion approach (higher methane productivity and smaller digestion volume).

The aim of this study is to identify the contributions to the final methane potential of the liquid and solid fractions obtained by centrifugation of thickened and thermally pretreated waste activated sludge, by performing biochemical methane production tests (BMP) on the different fractions, and a subsequent balance which integrates and compares the mass fractioning and methane production of the different phases in a global digestion scheme.

\section{MATERIALS AND METHODS}

\section{Sludge Sampling, Fractioning and Pretreatment}

A single sample of waste activated sludge (WAS) was taken from the municipal wastewater treatment plant of Valladolid (Spain) and thickened without polyelectrolyte to perform the research with concentrated sludge, that is the real feeding to pre-treatment units, as justified in Pérez-Elvira et al. (2008).

A fraction of the fresh WAS was treated in a thermal hydrolysis batch unit, where it was heated with live steam at $170{ }^{\circ} \mathrm{C}$ ( 8 bar $)$ during 50 minutes, and then suddenly decompressed to atmospheric pressure. The effect of the pretreatment on the sludge solubilisation was expressed as the ratio of soluble organic matter with respect to the total (SCOD/TCOD).

Solid and liquid fractions of both fresh ("CONTROL") and pre-treated ("TH") sludge were separated by centrifugation at $5000 \mathrm{rpm}$ for 10 minutes. Table 1 presents the results of the fractioning and phase characterization.

\section{Biochemical Methane Potential Tests (BMP)}

The evaluation of the anaerobic digestion of the different samples (total, solid and liquid fractions) was performed in BMP assays at $35^{\circ} \mathrm{C}$, conducted in triplicate in $160 \mathrm{~mL}$ serum bottles filled with $50 \mathrm{~mL}$ of a mixture of anaerobic inoculum (from the digester of a municipal WWTP, 15 days SRT) and the corresponding substrate (fresh WAS, hydrolyzed WAS, or solid and liquid fractions of both) at a substrate to inoculum ratio (SIR) of $0.5 \mathrm{~g} / \mathrm{g}$ (on VS basis). During the test, the bottles were incubated in a thermostated chamber in an orbital shaker. Methane production in the BMP assays was recorded by periodic measurements of pressure and biogas composition in the headspace of the bottles. The specific methane production was expressed with respect to the volatile solids of substrate fed to each test (mL $\mathrm{CH}_{4} / \mathrm{g}$ VS). The endogenous methane production of the inoculum was subtracted from the total methane production in the BMP tests to obtain the real methane production of each substrate.

\section{Analytical Methods}

Total solids (TS), volatile solids (VS), total chemical oxygen demand (TCOD) and soluble chemical oxygen demand (SCOD) concentrations were determined according to Standard Methods (21st edition, 2005). The soluble phase for SCOD was obtained by centrifugation at $5000 \mathrm{rpm}$ for 10 minutes. The pressure in the headspace of the BMP bottles was measured with a pressure sensor PN 5007 (IFM, Germany), and biogas composition was determined using a gas chromatograph coupled with a thermal conductivity detector (Varian CP-3800, USA).

\section{RESULTS AND DISCUSSION}

\section{Sludge Characterization and Thermal Hydrolysis Performance}

Table 1 presents the fractioning balance obtained in the centrifugation, the characterization of the different samples in terms of solids and COD, and the ratio $\mathrm{SCOD} / \mathrm{TCOD}$ in each sample (no SCOD can be measured in solid fractions).

Table 1: Sludge fractioning and characterization of the different fractions (total, solid and liquid) before (CONTROL) and after (TH) the pretreatment, and soluble COD ratio.

\begin{tabular}{|l|c|c|c|c|c|}
\hline & TS & VS & TCOD & SCOD & SCOD/TCOD \\
\cline { 2 - 6 } & $\mathbf{g} / \mathbf{k g}$ & $\mathbf{g} / \mathbf{k g}$ & $\mathbf{m g} / \mathbf{L}$ & $\mathbf{m g} / \mathbf{L}$ & $\mathbf{\%}$ \\
\hline CONTROL & 132.1 & 104.6 & 164,000 & 19,120 & 12 \\
CONTROL-LIQUID & 15.4 & 10.9 & 24,651 & 19,120 & 78 \\
CONTROL-SOLID & 137.6 & 108.9 & 245,110 & -- & - \\
TH & 78.3 & 59.5 & 100,063 & 36,947 & 37 \\
TH-LIQUID & 31.7 & 27.6 & 37.500 & 36,947 & 99 \\
TH-SOLID & 208.4 & 149.2 & 344.825 & -- & -- \\
\hline
\end{tabular}


Comparing the values of TCOD and TS of "CONTROL" and "TH" samples, it can be observed that sludge is diluted by steam condensation (1.7 dilution factor). The corresponding SCOD/TCOD ratios of both samples exhibit that $30 \%$ of the particulate matter was solubilized during the thermal pretreatment.

\section{Methane Potential of Control and Hydrolyzed Fractions}

Figure 1 presents the digestion curves obtained in the BMP tests. It can be observed that, in the untreated sludge, the methane production of the solid and liquid fractions is similar, although the liquid phase presented an unexpected 5 days lag-phase, probably due to the fact that this phase is the result of the centrifugation of a thickened sludge, and therefore not representative of the real soluble easily

degradable phase. As expected, the methane production of the hydrolyzed sludge was higher compared to the untreated ( 329 vs. $259 \mathrm{~mL} \mathrm{CH}_{4} / \mathrm{g} \mathrm{VS}_{\mathrm{fed}}$ ), representing a $30 \%$ increase in the methane production with respect to the particulate phase, which is consistent with the $30 \%$ solubilisation of the particulate phase obtained. The fractioning of the hydrolyzed sludge showed that the contribution of the enhancement in methane production and kinetics after the hydrolysis is due to the liquid fraction, remaining the solid fraction difficult to degrade.

\section{Performance of Thermal Hydrolysis in Solid and Liquid Fractions}

As announced in the previous discussion, it is interesting to compare the separate performance of liquid and solid fractions. Figure 2 compares the results obtained in the BMP for each phase.

UNTREATED SLUDGE

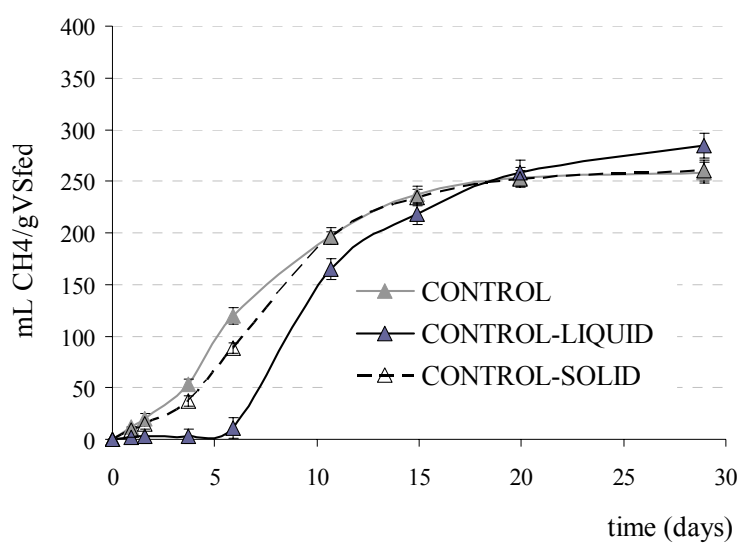

HYDROLYSED SLUDGE

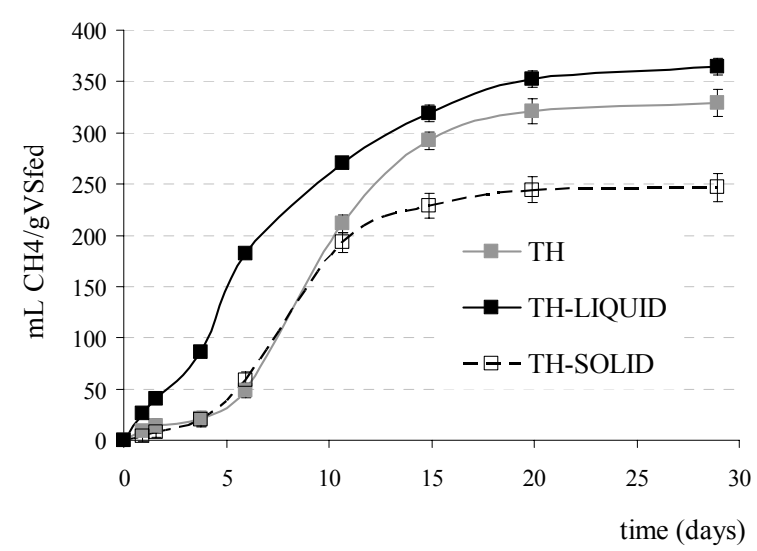

Figure 1: Methane production curves in the BMP test performed for the different fractions of WAS (total, liquid and solid) before (CONTROL) and after (TH).

LIQUID FRACTIONS

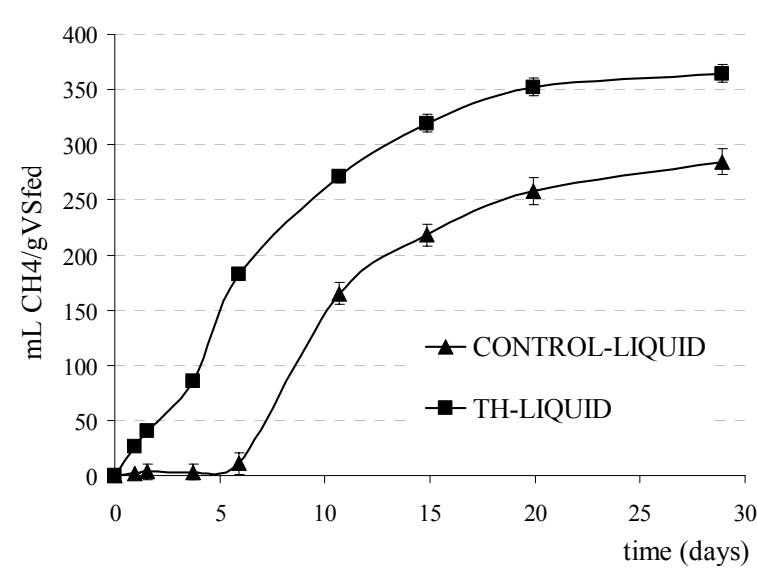

SOLID FRACTIONS

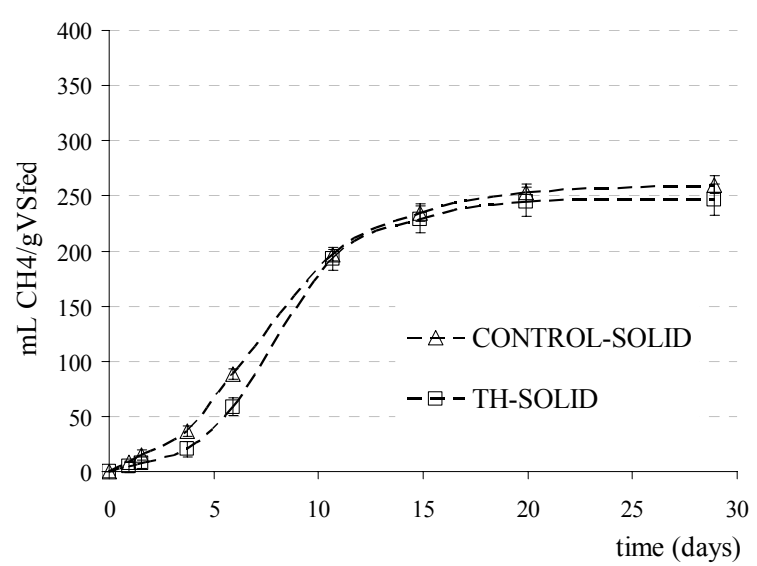

Figure 2: Comparison of the methane production curves for untreated (control) and pre-treated (TH) in the solid and liquid fractions. 
The thermal hydrolysis pre-treatment increased the methane production due to the solubilisation of solids, which moved to the liquid phase, obtaining a value of $370 \mathrm{~mL} \mathrm{CH} / \mathrm{g} \mathrm{VS}_{\text {fed }}$ in this liquid phase. However, the methane production of the solids remained similar to the original value for the solid phase, around $260 \mathrm{~mL} \mathrm{CH}_{4} / \mathrm{g} \mathrm{VS}_{\text {fed. }}$.

\section{Global Evaluation from Mass Balances}

Although the previous results exhibit very useful information to understand the performance of the thermal pretreatment on the sludge. This is useless if the corresponding mass balances are not performed, as the contribution of solid and liquid fractions is key to an overall evaluation. From the experimental data obtained, mass balances were performed in order to quantify the influence of each fraction (liquid and solid) on the total methane production.

A calculation basis of $1 \mathrm{~kg}$ of sludge to be digested was considered, and the experimental data were translated into a methane production parameter, expressed as the $\mathrm{CH}_{4}$ obtained per kilogram of sludge fed to digestion.

Table 2 presents the experimental data extracted from the previous discussion, together with the results of the balances performed. Figure 3 compares the methane production per kilogram of sludge treated in the different fractions.

From this analysis, it is evident that the advanced digestion that combines thermal hydrolysis and anaerobic digestion presents a very noticeable difference with respect to the untreated sludge (control) in terms of the contribution of phases to the total methane production.

In the untreated sludge, the solid fraction is responsible for all the methane production, because the mass balance shows that the solid fraction accounts for $96 \%$ of the total mass (representing nearly $100 \%$ of the total VS). To complete a more realistic global balance, the liquid stream separated by centrifugation before the thickening of the WAS should be considered, although it is expected that this contribution would still be negligible.

In the case of the thermally pretreated sludge, the solid fraction is only $26 \%$ of the total mass, although it contains $66 \%$ of the VS to be degraded. The remaining $34 \%$ of VS released to the liquid phase are responsible for the production of $49 \%$ of the methane, with very different kinetics (higher rate, no lag-phase).

Table 2: Mass balances for VS feeding contribution and methane production for the total and the liquid/solid fractions of untreated (CONTROL) and thermally pretreated (TH) sludge.

\begin{tabular}{|l|c|c|c|c|c|c|}
\hline & \multicolumn{2}{|c|}{ EXPERIMENTAL DATA } & \multicolumn{3}{c|}{ MASS BALANCES } \\
\cline { 2 - 7 } & Mass values & $\begin{array}{c}\text { Phases } \\
\text { fractioning }\end{array}$ & $\begin{array}{c}\text { Specific } \\
\text { methane } \\
\text { production }\end{array}$ & $\begin{array}{c}\text { Contribution to } \\
\text { VS feeding }\end{array}$ & $\begin{array}{c}\text { Methane } \\
\text { production }\end{array}$ & $\begin{array}{c}\text { Contribution to } \\
\text { methane } \\
\text { production }\end{array}$ \\
\cline { 2 - 7 } & $\mathbf{( g )}$ & $\mathbf{\%}$ & $\mathbf{m L} \mathbf{C H}_{\mathbf{4}} / \mathbf{g} \mathbf{V S}_{\text {fed }}$ & $\mathbf{\%}$ & $\begin{array}{c}\mathbf{m L} \mathbf{C H}_{\mathbf{4}} / \mathbf{k g} \text { of } \\
\text { sludge digested }\end{array}$ & $\mathbf{\%}$ \\
\hline CONTROL & 1000 & $100 \%$ & 259 & & 27.2 & \\
CONTROL-LIQUID & 43 & $4 \%$ & 285 & $0.5 \%$ & 0.1 & $0.5 \%$ \\
CONTROL-SOLID & 957 & $96 \%$ & 260 & $99.5 \%$ & 27.1 & $99.5 \%$ \\
TH & 1758 & $100 \%$ & 329 & & 34.4 & \\
TH-LIQUID & 1297 & $74 \%$ & 370 & $34.2 \%$ & 16.7 & $48.6 \%$ \\
TH-SOLID & 461 & $26 \%$ & 257 & $65.8 \%$ & 17.7 & $51.4 \%$ \\
\hline
\end{tabular}

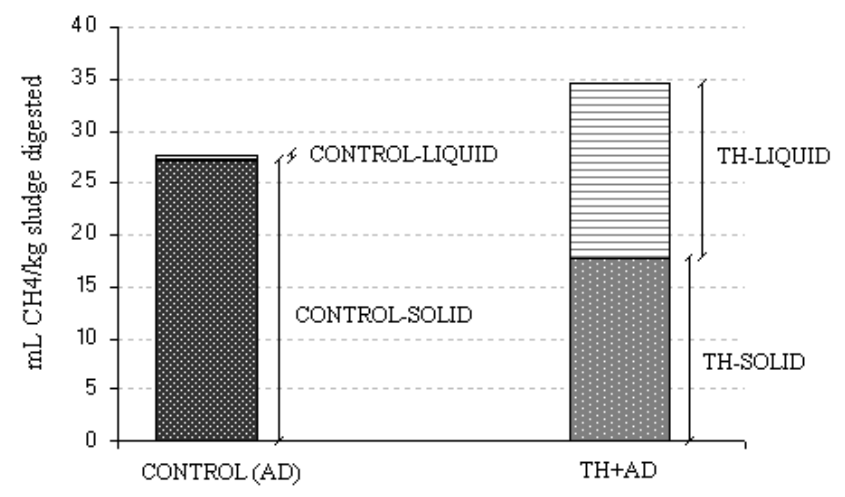

Figure 3: Methane production calculated per kilogram of sludge digested for the liquid and solid fractions of untreated (CONTROL) and thermally pretreated (TH) sludge. 
These results suggest the possibility of a new scenario for the anaerobic digestion of sludge, combining a thermal hydrolysis pre-treatment with the separate digestion of the liquid and solid fractions in digesters operated at different hydraulic retention times (HRT), thus decreasing the total digestion volume. The idea from the experimental results is that the organic content of the liquid phase presents faster degradation kinetics, corresponding to the compounds solubilised during the hydrolysis pre-treatment, while the solid phase still needs high retention time, similar to a conventional solids digester. Therefore, the separate digestion proposed operates at different HRT, with different digester rheologies and control.

\section{Proposal of a Separate Digestion Scenario}

Two scenarios were compared: Scenario A corresponds to the conventional digestion of sludge, at 3\% VS concentration and a HRT of 30 days.

Scenario B (presented in Figure 4) corresponds to the digestion scheme evaluated in this paper, consisting of a thermal hydrolysis pre-treatment followed by phase separation and digestion of solid and liquid phases in two different digesters, operated at different HRT.

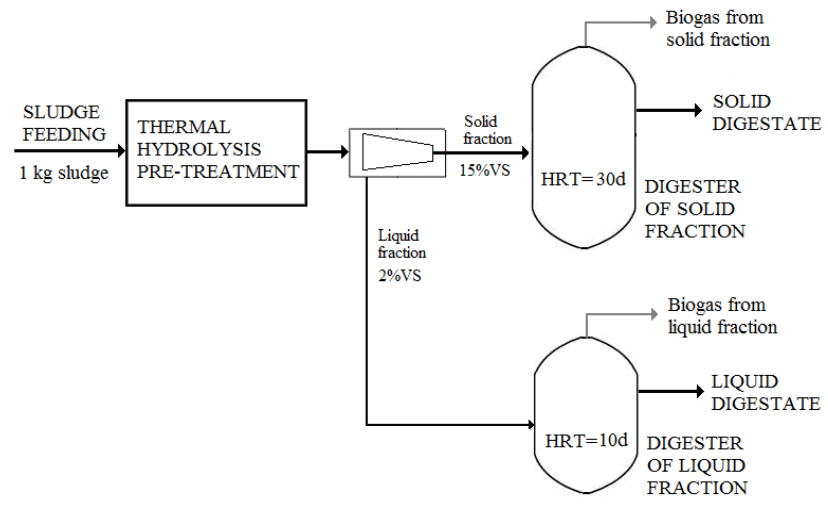

Figure 4: Proposed scenario for the digestion of separate solid and liquid phases resulting from a thermal hydrolysis pre-treatment.

Mass balances were performed for both scenarios according to the previously described calculation basis and methodology. However, as the HRT is a key parameter from the point of view of digester volume, the methane production obtained per kilogram of sludge feeding was expressed as methane productivity per day $(\mathrm{mL} \mathrm{CH} / 4 \mathrm{~kg}$ sludge.day) dividing by the HRT. This parameter really represents the productivity of the digester.
The results obtained are presented in Figure 5 for both scenarios A and B (separating liquid and solid digestion in this second case).

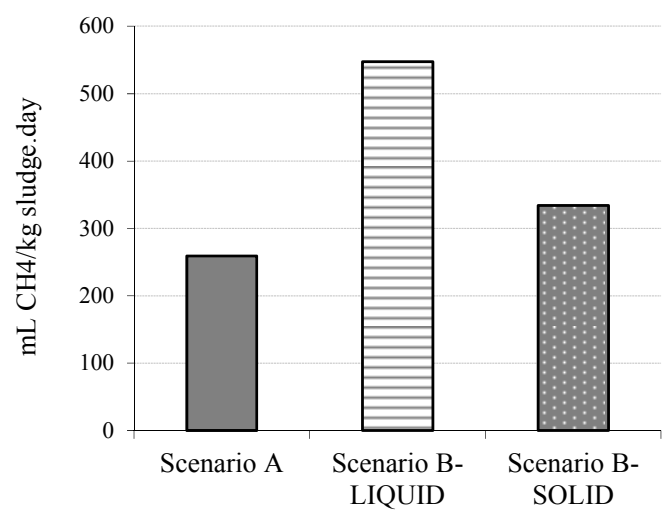

Figure 5: Methane productivity, calculated per kilogram of sludge digested and day, for the conventional sludge digestion (Scenario A) and the proposed advanced separate digestion scheme (Scenario B).

These values clearly exhibit that the digestion of the liquid fraction alone after the thermal hydrolysis of the sludge accounts for more than twice compared to the conventional digestion of the sludge. Furthermore, this "liquid-fraction digester", while operated at a similar sludge concentration compared to the conventional, is four times smaller.

Regarding the solid fraction, the methane productivity is slightly higher than the conventional digester, although this "solid-fraction digester" is again four times smaller compared to the conventional, while operated at a high concentration.

\section{CONCLUSIONS}

The study performed in this paper is based on the hypothesis that the combination of sludge pre-treatment $\left(170{ }^{\circ} \mathrm{C}, 50\right.$ minutes $)$ and the subsequent separate digestion of the solid and liquid fractions can result in a global better methane productivity digester and smaller digestion volume.

The results obtained for the methane potential of fresh and pre-treated solid and liquid fractions showed that the $30 \%$ increase in the methane production obtained after the pre-treatment (from 259 to $329 \mathrm{~mL}$ $\mathrm{CH}_{4} / \mathrm{g} \mathrm{VS}_{\text {fed }}$ ) corresponds to the enhancement in the methane production of the liquid fraction, due to the release of the particulate organic matter to this phase, while the biodegradability of the solid fraction remained constant after the pretreatment. 
The mass balances performed based on these experimental data showed that $34 \%$ of the VS were released to the liquid fraction, generating nearly $50 \%$ of the total methane produced per kilogram of sludge digested, with much faster kinetics compared to the solid fraction.

These results support the initial hypothesis of a separate digestion of the liquid and solid fractions resulting from thermal pre-treatment of sludge. This approach would result in decreasing the digestion volume to half while duplicating the methane productivity per kilogram of sludge fed to digestion.

\section{REFERENCES}

Bougrier, C., Delgenès, J. P. and Carrére, H., Effects of thermal treatments on five different waste activated sludge samples solubilisation, physical properties and anaerobic digestion. Chemical Engineering Journal, 139, 236-244 (2008).

Carrère, H., Bougrier, C., Castets, D. and Delgenes, J. P., Impact of initial biodegradability on sludge anaerobic digestion enhancement by thermal pretreatment. J. Environ. Sci. Health, Part - A, Toxic/ Hazard Subst. Environ. Eng., 43 (13), 1551-1555 (2008).

Carrère, H., Dumas, C., Battimelli, A., Batstone, D., Delgenes, J., Steyer, J. and Ferrer, I., Pretreatment methods to improve sludge anaerobic degradability: A review. Journal of Hazardous Materials, 183, 1-15 (2010).

Kepp, U., Machenbach, I., Weisz, N. and Solheim, O. E., Enhanced stabilisation of sewage sludge through thermal hydrolysis -3 years of experience with full scale plants. Water Sci. Technol., 42(9), 89-96 (1999).

Li, Y. Y. and Noike, T., Upgrading of anaerobic digestion of waste activated sludge by thermal pretreatment, Wat. Sci. Technol., 26(3-4), 857-866 (1992).

Neyens, E. and Baeyens, J., A review of thermal sludge pretreatment processes to improve dewaterability. Journal of Hazardous Materials, 98, 51-67 (2003).

Nozhevnikova, A. N., Kotsyurbenko, O. R. and Parshina, S. N., Anaerobic manure treatment under extreme temperature conditions. Wat. Sci. Tech., 40, 215-221 (1999).

Perez-Elvira, S. I., Fdz-Polanco, F., Fdz-Polanco, M., Rodríguez, P. and Rouge, P., Hydrothermal multivariable approach. Full-scale feasibility study. Electronic Journal of Biotechnology, 11(4), 7-8 (2008)

Rico, J. L., García, H., Rico, C. and Tejero, L., Characterisation of solid and liquid fractions of dairy manure with regard to their component distribution and methane production. Bioresource Technology, 98(5), 971-979 (2007).

Shimizu, T., Kudo, K. and Nasu, Y., Anaerobic waste activated sludge digestion-a bioconversion mechanism and kinetic model. Biotechnol. Bioeng., 41, 1082-1091 (1993).

Sutaryo, S., Warda, A. J. and Møllera, H. B., Anaerobic digestion of acidified slurry fractions derived from different solid-liquid separation methods. Bioresource Technology, 130, 495-501 (2013). 


\section{CHAPTER 8}

Assessment of "gas explosion" pre-treatment on the anaerobic digestion efficiency in terms of methane production 



\title{
Assessment of "gas explosion" pre-treatment on the anaerobic digestion efficiency in terms of methane production
}

\author{
I. Sapkaite, F. Fdz-Polanco, S.I. Pérez-Elvira*. \\ Department of Chemical Engineering and Environmental Technology. University of Valladolid. Spain. \\ (E-mail*: sarape@iq.uva.es)
}

\begin{abstract}
In this study the "gas explosion" pre-treatment of waste activated sludge and digestate was assessed at lab-scale under different variables combinations. The gases used were $\mathrm{CO}_{2}$ and $\mathrm{CH}_{4}$ Biochemical methane potential (BMP) tests were set-up to evaluate the anaerobic degradation of pretreated sludge. All the experimental sets improved poorly or did not improve at all the anaerobic digestion in terms of methane production. No significant differences between pre-treatment variables combinations or gas used were obtained. Moreover, sludge solubilisation was also negligible making no effect for digestion efficiency. Therefore, "gas explosion" pre-treatment does not seem an effective pre-treatment method for sludge solubilisation and anaerobic digestion efficiency improvement.
\end{abstract}

Keywords: anaerobic digestion; BMP; gas explosion; sludge pre-treatment; waste activated sludge

\section{INTRODUCTION}

A number of pre-treatment methods prior to anaerobic digestion (AD) have been developed and investigated in order to enhance the disintegration and solubilisation of sludge solids. They all induce the solubilisation of complex particulate matter, so it is more rapidly and completely consumed during anaerobic digestion, increasing the volume of biogas produced, and decreasing the amount of solids to be disposed (Pérez-Elvira et al. 2010).

In parallel with the popular thermal pre-treatment ("steam explosion") process, "gas explosion" technology as a pre-treatment method to improve anaerobic digestion is similarly used. The main difference of the processes is that instead of the steam used in thermal pre-treatment, biogas (or other soluble gas like $\mathrm{CO}_{2}, \mathrm{CH}_{4}$ or $\mathrm{NH}_{3}$ ) is applied for the substrate pressurisation in an alternative technology. The commercialized gas pre-treatment technology Cellruptor uses a unique pressure swing technology (few pressure-depressure cycles) to open up biosolids materials, such as waste activated sludge or crop biomass, to increase the rate of subsequent fermentative processes, including anaerobic digestion (Jolly et al. 2009). Depending on the nature of the feedstocks, biogas production rates may increase in the range $5-20 \%$ (Ecosolids).

The main feature of this process compared to thermal hydrolysis is direct biogas, produced during $\mathrm{AD}$, utilization for sludge pressurization. It means that no steam production is required. No additional energy is consumed. The biogas needed for sludge pre-treatment process is produced during sludge degradation, thus probably resulting in an energetically neutral or even self-sufficient process. However, there is no information about this hypothesis.

Despite of no relevant literature available, some results of the "gas explosion" technology can be find out in investigation works. Zheng et al. (1998) compared $\mathrm{CO}_{2}$ explosion with steam and ammonia explosion for pre-treatment of recycled paper mix, sugarcane bagasse, and re-pulping waste of recycled paper and found that $\mathrm{CO}_{2}$ explosion was more cost-effective than ammonia explosion. Further, it did not cause the formation of inhibitory compounds that could occur in steam explosion. Ma et al. (2011) performed a $\mathrm{CO}_{2}$ pre-treatment study with kitchen waste. The substrate was pressurized to 10 bar with $\mathrm{CO}_{2}$ as pressurizing gas. After few minutes of contact time, the depressurization of the reactor to atmospheric pressure ( 1 bar) was performed by quick release of the $\mathrm{CO}_{2}$ gas. The solubilisation achieved was just $12 \%$, however the cumulative biogas production was the highest, corresponding to $0.52 \mathrm{~L} / \mathrm{gCODt}$ removed. Thiruvenkadam (2011) in his master thesis 
reported Cellruptor pre-treatment (10 bar; $\left.\mathrm{CO}_{2}\right)$ being an effective technology in increasing the biogas production, especially with dry substrates, such as maize, hay, etc., than sewage sludge.

The objective of this study is to evaluate the effect of $\mathrm{CO}_{2}$ and $\mathrm{CH}_{4}$ gas pre-treatment for waste activated sludge and digestate on the anaerobic digestion efficiency in terms of methane production. Different pre-treatment variables combinations are applied.

\section{MATERIALS AND METHODS}

\section{Sludge sampling}

The substrates used in the study were waste activated sludge (WAS) and digested sludge (DG) from anaerobic digester. Both were taken from the municipal waste water treatment plant (WWTP) of Valladolid (Spain). The main characteristics of the substrates are given in Table 1:

Table 1. Substrates characteristics.

\begin{tabular}{|c|c|c|c|c|c|}
\hline & Sludge type & $T S(g / k g)$ & $V S(g / k g)$ & $D Q O_{T}\left(g O_{2} / L\right)$ & $D Q O_{S}\left(g O_{2} / L\right)$ \\
\hline \multirow{2}{*}{$\begin{array}{c}\mathrm{CO}_{2} \\
\text { explosion }\end{array}$} & WAS & 32,09 & 25,88 & 15,52 & 1,07 \\
\hline & DG & 39,03 & 24,06 & 22,81 & 0,19 \\
\hline \multirow{2}{*}{$\begin{array}{c}\mathrm{CH}_{4} \\
\text { explosion }\end{array}$} & WAS & 63,65 & 49,83 & 62,23 & 2,33 \\
\hline & $\mathrm{DG}$ & 44,41 & 23,71 & 37,02 & 5,03 \\
\hline \multirow{2}{*}{$\begin{array}{l}\mathrm{CH}_{4} \mathrm{Re}- \\
\text { explosion }\end{array}$} & WAS & 65,43 & 47,60 & 70,95 & 0,51 \\
\hline & DG & 21,20 & 11,69 & 15,74 & 0,54 \\
\hline
\end{tabular}

The anaerobic inoculum for the biochemical methane potential (BMP) tests was sampled from the anaerobic digester in the WWTP treating mixed sludge, and pre-incubated for 3 days at $35^{\circ} \mathrm{C}$ in a thermostated chamber prior to use in order to activate the microorganisms and to deplete most of the residual organic matter.

\section{$\mathrm{CO}_{2}$ and $\mathrm{CH}_{4}$ pre-treatments, operating variables and experimental set-up}

The experiment was carried out in a lab-scale pre-treatment plant (Figure 1), which consists of a 1.5 $\mathrm{L}$ reactor pressurised with the corresponding gas from a gas bottle, and connected to an atmospheric flash tank $(6 \mathrm{~L})$ by a decompression valve that opens in a gas-explosion effect (sudden decompression).

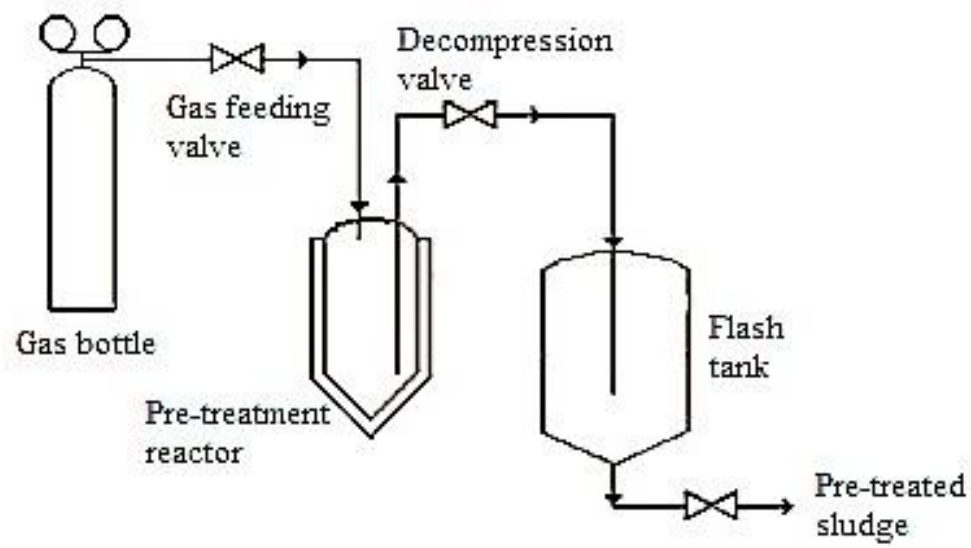

Figure 1. Gas pre-treatment system.

Two types of sludge were pre-treated: waste activated sludge and digested sludge. $\mathrm{CO}_{2} \& \mathrm{CH}_{4}$ pre-treatment process conditions were the same: pressure 5 or 8 bar, measured by a pressure meter, 
time 1 or 10 minutes, measured by a chronometer and fast or slow decompression. In a third experiment set $\left(\mathrm{CH}_{4}\right.$ Re-explosion) pre-treatment pressure was 6 bars and time 1 min with fast or slow depressure. Moreover, pressure-depressure cycles were introduced in this experiment. One pressure-depressure cycle means that after the usual pre-treatment process sludge was introduced again to the reactor, pressurised till 6 bars, maintained for 1 min and flashed to the atmospheric tank. Two and three pressure-depressure cycles mean that pre-treated sludge was 2 or 3 times returned to the reactor for process repetition. Zero cycles means the usual pre-treatment procedure. The operation is batch and controlled manually.

\begin{tabular}{l|l}
$\mathrm{CO}_{2}$ explosion & Substrate: WAS, DG \\
\hline $\mathrm{CH}_{4}$ explosion & $\begin{array}{l}\text { Pressure: } 5,8 \text { bar } \\
\text { Depressure: fast, slow } \\
\\
\text { Time: } 1,10 \text { min }\end{array}$
\end{tabular}

\begin{tabular}{l|l}
$\mathrm{CH}_{4}$ Re-explosion & Substrate: WAS, DG \\
& Pressure: 6 bar \\
Depressure: fast, slow \\
Time: 1 min \\
P-d cycles: $0,1,2,3$
\end{tabular}

\section{Biochemical methane potential tests (BMP)}

BMP assays were conducted in triplicate using $160 \mathrm{~mL}$ serum bottles, filled a mixture of anaerobic inoculum and the corresponding substrate at a substrate to inoculum ratio (SIR) of $0.5 \mathrm{~g} / \mathrm{g}$ on volatile solids (VS) basis. Micronutrients and macronutrients were added to the assays ensuring no nutritional limitation for optimal function of anaerobic microorganisms. Moreover, $\mathrm{NaHCO}_{3}$ and $\mathrm{Na}_{2} \mathrm{~S}$ were added to provide buffer capacity and avoid aerobic conditions respectively. The methodology used was the one suggested by Angelidaki et al. (2009).

The bottles were incubated in a thermostated chamber at $35^{\circ} \mathrm{C}$ in an orbital shaker at 150 $\mathrm{rpm} / \mathrm{min}$. Methane production in the BMP tests was determined by periodic measurements of pressure and biogas composition in the headspace of the bottles. Blanks containing only anaerobic inoculum were mounted to determine the endogenous methane production from the remaining organic matter that comes with the inoculum, which was subtracted from the total methane production in the BMP tests to obtain the real methane production of the substrate.

\section{Analytical methods and prediction parameters}

Total solids (TS) and volatile solids (VS) concentrations were determined according to Standard Methods, 21st edition (APHA, 2005). The total COD was obtained by a direct COD analysis. For the soluble COD determination the sample was previously centrifuged at $5000 \mathrm{rpm}$ for 10 minutes and filtrated using a $47 \mathrm{~mm}$ hydrophilic Glass Fiber filter with a $0.7 \mu \mathrm{m}$ pore size (AP40). The pressure in the headspace of the BMP bottles was measured with a pressure sensor PN 5007 (IFM, Germany), and biogas composition was determined using a gas chromatograph coupled to a thermal conductivity detector (Varian CP-3800, USA).

Table 2 summarizes the target parameters calculated. The performance of the digestion was calculated by comparing the $\mathrm{CH}_{4}$ values obtained for the treated samples with respect to the untreated, calculating the increase in methane production $\left(\Delta \mathrm{CH}_{4} \%\right)$. 
Table 2. Performance parameters.

\begin{tabular}{llll}
\hline Parameter & Symbol & Units & Equation \\
\hline $\begin{array}{l}\text { Sludge } \\
\text { solubilisation }\end{array}$ & $\mathrm{SF}$ & $\%$ & $\left.\% \mathrm{SF}=\frac{(\mathrm{SCOD} / \mathrm{TCOD})_{T H}-(S C O D / T C O D)_{0}}{((T C O D-S C O D) / T C O D}\right)_{0}$ \\
\hline $\begin{array}{l}\text { Specific methane } \\
\text { production }\end{array}$ & $\mathrm{CH}_{4}$ & $\mathrm{~mL} \mathrm{CH}_{4} / \mathrm{g} \mathrm{VS}_{\text {fed }}$ & $\mathrm{CH}_{4}=\frac{m L C H_{4}}{g V S_{f e d}}$ at standard conditions $\left(0^{\circ} \mathrm{C}, 1 \mathrm{~atm}\right)$ \\
\hline $\begin{array}{l}\text { Increase in methane } \\
\text { production }\end{array}$ & $\mathrm{NCH}_{4}$ & $\%$ & $\% \mathrm{CH}_{4}=\frac{\left(\mathrm{CH}_{4}\right)_{T H}-\left(\mathrm{CH}_{4}\right)_{0}}{\left(\mathrm{CH}_{4}\right)_{0}} \times 100$ \\
\hline
\end{tabular}

\section{RESULTS AND DISCUSSION}

\section{$\mathrm{CO}_{2}$ and $\mathrm{CH}_{4}$ pre-treatments}

The results of the cumulative methane production from the anaerobic digestion (BMP) of pretreated waste activated sludge and digestate are presented in Figure 2.
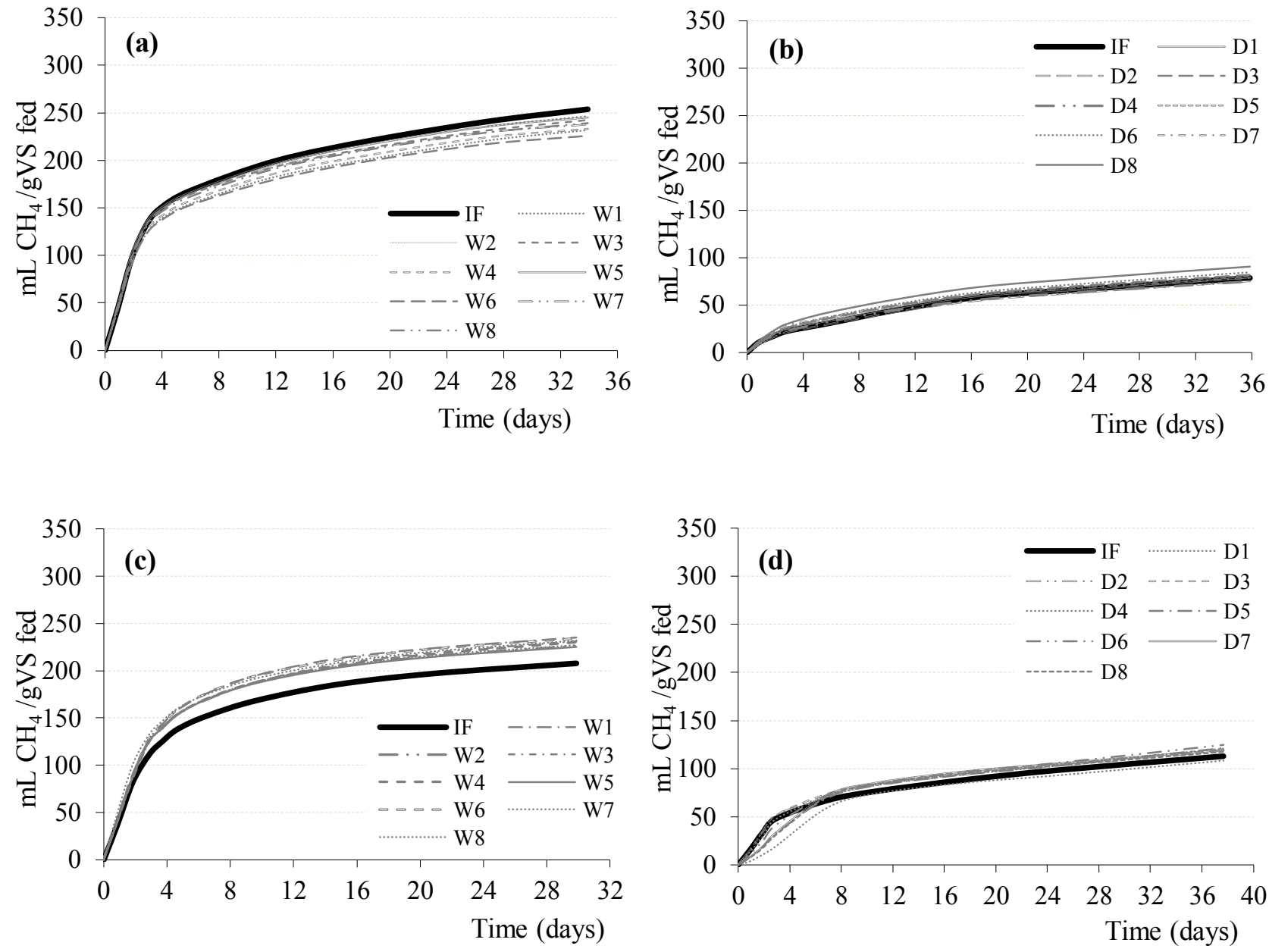

Figure 2. Evolution of the methane production of: (a) $\mathrm{CO}_{2}$ pre-treatment of waste activated sludge (W); (b) $\mathrm{CO}_{2}$ pre-treatment of digestate (D); (c)\&(d) $\mathrm{CH}_{4}$ pre-treatment of waste activated sludge and digestate.

Looking at the BMP curves the first and clear impression is that all the variable configurations tested in both $\mathrm{CO}_{2}$ and $\mathrm{CH}_{2}$ pre-treatment had no effect on final methane production of waste activated sludge and digestate. Neither 8 or 5 bar nor 1 or 10 pre-treatment minutes with fast or slow decompression did not show any notable difference in four experiment sets. The further concern is 
that despite the unfavorable effect of different pre-treatment conditions on methane production, the latter was negligible or not at all improved. From the Figures 2 (a) and (c) can be better seen the difference between pre-treated samples and un-treated fresh sludge (IF). In case of $\mathrm{CO}_{2}$ explosion with WAS (a) it is clearly seen the negative influence of the pre-treatment on the methane production where absolutely all pre-treated samples produced less methane than the untreated sludge. On the contrary, with $\mathrm{CH}_{4}$ gas pre-treated WAS sludge (c) showed a small improvement on methane production. In other two experiment sets (b) and (d) the pre-treated waste activated sludge and digestate produced almost the same amount of methane like untreated sludge.

For more precise pre-treatment study analysis experimental set-up and corresponding results are summarized in Table 3.

Table 3. Experimental data and performance parameters.

\begin{tabular}{|c|c|c|c|c|c|c|c|c|c|c|}
\hline & \multirow[b]{2}{*}{ Trial } & \multicolumn{3}{|c|}{ Pre-treatment conditions } & \multicolumn{3}{|c|}{ Waste activated sludge } & \multicolumn{3}{|c|}{ Digestate } \\
\hline & & $\begin{array}{c}\text { Pressure } \\
\text { (bar) }\end{array}$ & Depressure & $\begin{array}{l}\text { Time } \\
\text { (min) }\end{array}$ & $\begin{array}{c}\mathrm{CH}_{4} \\
\text { production } \\
\left(\mathrm{mL} / \mathrm{g} V S_{\text {fed }}\right)\end{array}$ & $\begin{array}{c}\boldsymbol{A C H}_{4} \\
(\%)\end{array}$ & $\begin{array}{l}S B \\
(\%)\end{array}$ & $\begin{array}{c}\mathrm{CH}_{4} \\
\text { production } \\
\left(\mathrm{mL} / \mathrm{g} V S_{\text {fed }}\right)\end{array}$ & $\begin{array}{c}\mathrm{ACH}_{4} \\
(\%)\end{array}$ & $\begin{array}{l}S B \\
(\%)\end{array}$ \\
\hline \multirow{9}{*}{5} & IF & & & & 254 & & & 79 & & \\
\hline & W1 & 8 & $\mathrm{f}$ & 1 & 231 & -8.8 & 1.2 & 79 & 0.0 & 4.4 \\
\hline & W2 & 5 & $\mathrm{f}$ & 1 & 246 & -2.9 & 2.2 & 75 & -5.1 & 4.6 \\
\hline & W3 & 8 & $\mathrm{~s}$ & 1 & 242 & -4.5 & 0.6 & 82 & 3.8 & 6.9 \\
\hline & W4 & 5 & $\mathrm{~s}$ & 10 & 233 & -8.2 & 2.2 & 74 & -6.3 & 3.2 \\
\hline & W5 & 8 & $\mathrm{~s}$ & 10 & 245 & -3.5 & 4.3 & 81 & 2.5 & 4.3 \\
\hline & W6 & 5 & $\mathrm{~s}$ & 1 & 225 & -11.1 & 1.0 & 84 & 6.3 & 4.9 \\
\hline & W7 & 5 & $\mathrm{f}$ & 10 & 237 & -6.4 & 0.0 & 78 & -1.3 & 4.3 \\
\hline & W8 & 8 & $\mathrm{f}$ & 10 & 239 & -5.9 & 0.0 & 90 & 13.9 & 4.7 \\
\hline & IF & & & & 208 & & & 113 & & \\
\hline & D1 & 8 & $\mathrm{f}$ & 1 & 235 & 13.1 & 3.0 & 121 & 7.1 & 6.0 \\
\hline & D2 & 5 & $\mathrm{f}$ & 1 & 226 & 8.7 & 3.2 & 119 & 5.3 & 6.9 \\
\hline & D3 & 8 & $\mathrm{~s}$ & 1 & 231 & 11.1 & 2.5 & 119 & 5.3 & 6.7 \\
\hline & D4 & 5 & $\mathrm{~s}$ & 10 & 230 & 10.6 & 2.5 & 109 & -3.5 & 5.8 \\
\hline & D5 & 8 & $\mathrm{~s}$ & 10 & 225 & 8.3 & 3.5 & 121 & 7.1 & 6.1 \\
\hline & D6 & 5 & $\mathrm{~s}$ & 1 & 234 & 12.5 & 2.6 & 125 & 10.6 & 5.2 \\
\hline & D7 & 5 & $\mathrm{f}$ & 10 & 227 & 9.3 & 3.9 & 120 & 6.2 & 5.5 \\
\hline & D8 & 8 & $\mathrm{f}$ & 10 & 232 & 11.4 & 3.0 & 117 & 3.5 & 5.0 \\
\hline
\end{tabular}

Talking about the sludge solubilisation, the highest values were obtained for digestate after $\mathrm{CO}_{2}$ (4.7\%) and $\mathrm{CH}_{4}$ (5.9\%) pre-treatment (average values). This could be explained due to the different and less complex composition of sludge compared to waste activated sludge. However, the improvement of methane production in these experiment sets was insignificant even if the sludge solubilisation was the most noticeable. In the experiments with waste activated sludge the solubilisation was poor reaching the average values of $1.4 \%$ and $3 \%$ after the $\mathrm{CO}_{2}$ and $\mathrm{CH}_{4}$ pretreatments, respectively. The quantity of the methane produced after $\mathrm{CO}_{2}$ gas pre-treatment was less in all the trials compared to untreated sludge $\left(<254 \mathrm{~mL} \mathrm{CH}_{4} / \mathrm{g}\right.$ VSfed) and after $\mathrm{CH} 4$ pre-treatment on the contrary, major compared to the fresh sludge $\left(>208 \mathrm{~mL} \mathrm{CH}_{4} / \mathrm{g}\right.$ VSfed). This difference between experiment sets could be explained in two ways: the first, it could probably be because of the different gas used and the second, it could be because of the different sludge sample. There is no information in the literature about the influence of the gas used to the pre-treatment efficiency. 


\section{$\mathrm{CH}_{4}$ Re-pre-treatment}

Figure 3 presents anaerobic digestion curves obtained in a BMP tests after $\mathrm{CH}_{4}$ re-explosion. The main difference of these experimental trials compared to the previous is the pressure-depressure variable. In some trials (with 1, 2 or 3 pressure-depressure cycles) the pre-treated sludge was returned again to the reactor for pre-treatment procedure repetition.

In a Figure 3 (a) a quite significant methane production behaviour between trials W1 - W4 and W5 -W8 can be seen during the first 12 - 16 days of anaerobic digestion. Experiment trials W5 W8 at the pre-treatment procedure had a slow depressure type, meaning no "gas explosion". Probably therefore these four trials had a marked lag phase in the beginning of the digestion process meaning a toxic or difficult biodegradable compounds.
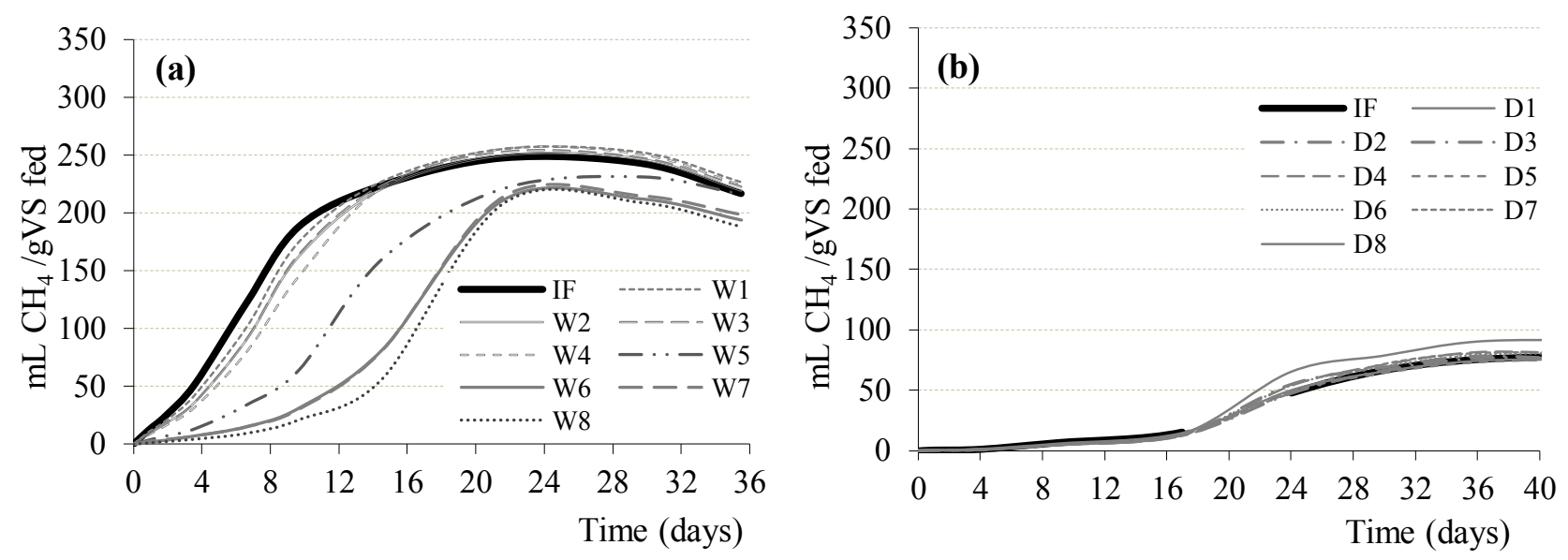

Figure 3. Evolution of the methane production of: (a) $\mathrm{CH}_{4}$ pre-treatment waste activated sludge (W); (b) $\mathrm{CH}_{4}$ pre-treatment digestate (D).

The final methane production at the end of the test of these four trials was less compared to the untreated sludge $\left(<217 \mathrm{~mL} \mathrm{CH}_{4} / \mathrm{g}\right.$ VSfed). Other W1 - W4 experiment trials improved anaerobic biodegradability in term of methane production negligible. Talking about digestate, all the pretreatment trials had a marked lag phase of approximately 16 days and no significant improvement of methane production was observed. Moreover, pressure-depressure variable did not affect sludge pretreatment process for methane production improvement.

Experimental data and performance parameters are presented in Table 3. 
Table 3. Experimental set-up and performance parameters.

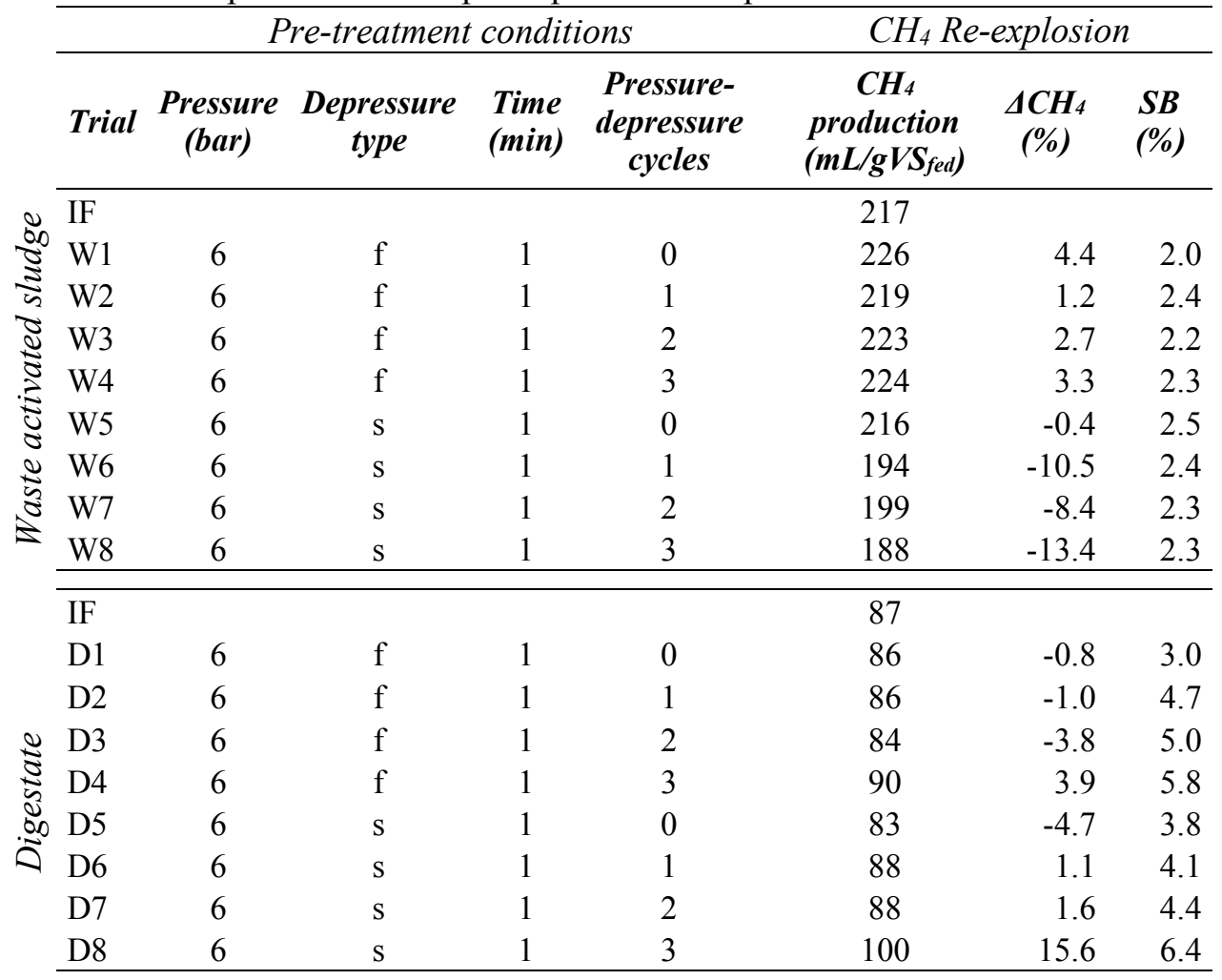

Generally, all the experimental sets discussed improved poorly or did not improve at all the anaerobic digestion in terms of methane production. No significant differences between pretreatment variables combinations or gas used were obtained. Moreover, sludge solubilisation was also negligible making no effect for digestion efficiency. Even there is just a few literature sources, the scarce results obtained in this study can be compared to ones from other researches. Ma et al. (2011) performed a $\mathrm{CO}_{2}$ pre-treatment study with kitchen waste. The solubilisation achieved was just $12 \%$, however, the cumulative biogas production was the highest, corresponding to $0.52 \mathrm{~L} / \mathrm{gCODt}$ removed. This discrepancy between the solubilisation effect and the biodegradability was explained by the dependence on the mode of pressurization (number of pressure-depressure cycles) and the pressure applied. Thiruvenkadam (2011) in his master thesis reported gas pre-treatment (10 bar; $\mathrm{CO}_{2}$ ) being an effective technology in increasing the biogas production, especially with dry substrates, such as maize, hay, etc., than sewage sludge. From the batch experiments, $\mathrm{CO}_{2}$ pretreatment showed maximum and minimum increase of methane yield in hay $(32 \%)$ and dewatered waste activated sludge sludge $(2 \%)$ respectively.

\section{CONCLUSIONS}

Evaluating the influence of gas pre-treatment with different variables combinations on anaerobic digestion of waste activated sludge and digestate, the main conclusion is that gas explosion pretreatment does not seem an effective pre-treatment method for sludge solubilisation and anaerobic digestion efficiency improvement. Results obtained in this study were insignificant at all the pretreatment conditions tested.

\section{REFERENCES}

Angelidaki, I., Alves, M., Bolzonella, D., Borzacconi, L., Campos, J.L., Guwy, A.J., Kalyuzhnyi, S., Jenicek, P., Van Lier, J.B. (2009). Defining the biomethane potential (BMP) of solid organic wastes and energy crops: a proposed protocol for batch assays. Water Science and Technology, 59(5), 927-934. 
Ecosolids [online]. Available at: https://www.environmental-expert.com/products/cellruptor-140806 [access 2016/08/10].

Jolly, M., Gillard, J. (2009). The economics of advanced digestion. 14th European Biosolids and Organic Resources Conference and Exhibition. United Kingdom.

Ma, J., Duong, T.H., Smits, M., Verstraete, W., Carballe, M. (2011). Enhanced biomethanation of kitchen waste by different pre-treatments. Bioresource Technology 102, 592-599.

Pérez-Elvira, S.I., Fdz-Polanco, M., Fdz-Polanco, F. (2010). Increasing the performance of anaerobic digestión: Pilot scale experimental study for thermal hydrolysis of mixed sludge. Frontiers of Environmental Science \& Engineering 4(2), 135-141.

Thiruvenkadam, S. (2011). Evaluation of Cellruptor pre-treatment on biogas yield from various substrates. Masther thesis. Department of Biotechnology, Royal Institute of Technology, Stockholm, Sweden.

Zheng, Y.Z., Lin, H.M., Tsao, G.T. (1998). Pretreatment for cellulose hydrolysis by carbon dioxide explosion. Biotechnology Progress 14, 890-896. 
2 CHAPTER 9

\section{General discussion and conclusions}



While anaerobic digestion of sludge is the only choice to recover energy in wastewater treatment, although limited by the low biodegradability of secondary sludge, the introduction of a pre-treatment prior to the digester is worldwide accepted as the most attractive alternative. Moreover, thermal hydrolysis has demonstrated to be the most profitable and reliable technology on the market.

A substantial number of laboratory studies and full-scale applications over the years have documented many thermal pre-treatment advantages for anaerobic digestion and overall sludge treatment improvement. However, at both laboratory- and full-scale the process efficiency could vary quite widely or even appear contrary due to many variables involved in the process (described in previous chapters).

The crucial factors for thermal hydrolysis pre-treatment are:

- Sludge type: While primary sludge is already readily degradable and pre-treatment has less effectiveness, thermal hydrolysis of waste activated sludge is known to be more effective. Therefore, waste activated sludge was selected for this thesis due to its low biodegradability and difficult further treatment.

- Sludge concentration: The water content of the sludge is an especially important factor for pre-treatment economy, since increasing the dry solids of the sludge intrinsically reduces process energy requirements. Sludge concentration of app. 14\% DS was fixed for all the experiments based on literature and on previous studies performed by this research group. Further thickening $>18 \%$ DS may incur heat transfer limitation as well as practical processing concerns.

- Process configuration and energy integration: The optimization of the the global process scheme and the energy integration is absolutely necessary in order to recover the energy from biogas, to minimize the energy required to operate the thermal process and to maximize the global economy (while subjected to market values for energy and biosolids). A key equipment is the Combined Heat and Power (CHP) technology, which generates both electricity and heat from a single fuel source at the same time. The optimization of the recovery of heat from hot streams and the global energy integration is a mayor issue for the full scale, while directly related to the process operation conditions. In order to make profitable the energy demand of the thermal process, the three main goals to optimize are: methane production increase (for power generation of the CHP), changes in sludge rheology 
(decrease mixing and pumpingenergy) and improved dewaterability (which reduces downstream transport and processing requirements).

- Operation conditions for the thermal pre-treatment: The performance of the process, together with the energy requirements, depends directly on the operation conditions established. The reported bibliography about factors and values vary in a rather wide range:

\begin{tabular}{c|c|c|c|c|c}
\multicolumn{3}{c|}{ Laboratory-scale TH } & \multicolumn{3}{c}{ Full-scale TH } \\
\hline $\mathrm{T}\left({ }^{\circ} \mathrm{C}\right)$ & $\mathrm{t}(\mathrm{min})$ & Steam explosion & $\mathrm{T}\left({ }^{\circ} \mathrm{C}\right)$ & $\mathrm{t}(\mathrm{min})$ & Steam explosion \\
\hline $60-270$ & $10-180$ & without/with & $140-220$ & $15-70$ & without/with
\end{tabular}

Knowing that thermal hydrolysis is an energy-consuming process, the proper selection of the pretreatment conditions is indispensable, since it plays a key role on the process economics. For this reason part of the studies performed in present thesis were devoted to find the optimum conditions for thermal pre-treatment of waste activated sludge. The thermal pre-treatment factors evaluated in the thesis were combinations of temperature and time, and the steam explosion effect (as scarce bibliography is reported on this issue). The process efficiency was evaluated as the improvement of two parameters: i) sludge solubilisation during the pre-treatment process, and ii) methane production during the anaerobic digestion.

An initial analysis performed in a wide range of experimental conditions $\left(110-180^{\circ} \mathrm{C}, 5-50\right.$ min, $0-3$ flashes) exhibited that the thermal pre-treatment of waste activated sludge increases both the solubilisation (up to $40 \%$ ) and anaerobic biodegradability (up to $60 \%$ ).

The application of statistical analysis demonstrated that efficiency of the thermal pre-treatment is mainly influenced by temperature and by the steam-explosion effect. However, the reaction time and the re-flashing have a lower affect. A maximum methane production $\left(362 \mathrm{mLCH}_{4} / \mathrm{gVS}_{\text {fed }}\right)$ was predicted for the pre-treatment at $163^{\circ} \mathrm{C}$ for $35 \mathrm{~min}$ and sudden decompression. This optimum did not match with the optimum in solubilisation $\left(41 \%\right.$ at $180^{\circ} \mathrm{C}, 49 \mathrm{~min}$, sudden decompression), thus exhibiting the first conclusion: thermal hydrolysis has no joint optimum conditions for methane production and solubilisation, and sludge solubilisation should not be used as a prediction criterion to quantify pre-treatment efficiency, since it is not directly related to methane production. On the other hand, for the high intensity pre-treatment (high temperature and long times) sludge biodegradability increased, although solubilisation had increase, indicating that some soluble but non-biodegradable compounds were produced during severe thermal hydrolysis. These results were further confirmed after the experimental evaluation of thermal hydrolysis at exceeding the limiting temperature 
$\left(200^{\circ} \mathrm{C}\right)$. The possible formation of complex substances also appeared at lower temperatures for longer pre-treatment times.

A second clear conclusion is that it is not necessary an exhaustive control of thermal pretreatment conditions. An increase in methane production exceeding $50 \%$ was obtained by a thermal hydrolysis performed in the range $140-170^{\circ} \mathrm{C}$ heating and $5-35 \mathrm{~min}$. From here a relevant technical aspect to be mentioned is that at higher pre-treatment temperature, shorter reaction time is required. These results are very interesting in order to minimize energy requirement of thermal hydrolysis process.

A novel configuration of separate digestion of liquid and solid fractions of thermally pre-treated secondary sludge showed to be very interesting in terms of global digestion optimization. The mass balances performed based on the experimental data demonstrated that $34 \%$ of the VS of thermally pre-treated secondary sludge were released to the liquid fraction, generating nearly $50 \%$ of the total methane produced per kilogram of sludge digested, with much faster kinetics compared to the solid fraction. Therefore, the application of separate liquid-solid fractions digestion of thermally pretreated secondary sludge would result in decreasing the total digestion volume and, to the same, improving energy benefits due to the digesters operated at different hydraulic retention times.

The alternative pre-treatment method - "gas explosion" originally seemed to be a quite attractive sludge pre-treatment process. The main feature of this process compared to thermal hydrolysis is direct biogas, produced during anaerobic digestion, utilization for sludge pressurization, what means, that no steam production is required, no additional energy is consumed. However, the evaluation of $\mathrm{CO}_{2}$ and $\mathrm{CH}_{4}$ gas pre-treatment for waste activated sludge and digestate on the anaerobic digestion efficiency showed to be an ineffective pre-treatment method for sludge solubilisation and anaerobic biodegradability. Moreover, no significant differences between pre-treatment variables combinations or gas used were obtained.

The specific conclusions of the present thesis, matching with the particular objectives stablished in section 1.2., are:

1. Sludge solubilisation cannot be used as prediction criterion to quantify pre-treatment efficiency, since it is not directly related to methane production. The solubilisation response for the different factors evaluated (temperature, time and decompression) was not directly related in the evaluated operating range with subsequent methane production through anaerobic digestion. 
2. The pre-treatment factors that mainly influence the increase in methane production, in the ranges evaluated are temperature $\left(110-200^{\circ} \mathrm{C}\right)$ and decompression way, while the duration of the heating $(5-50 \mathrm{~min})$ exhibited to have quite low relevance. Regarding the effect of steam explosion, a great positive effect was obtained, thus confirming the convenience of this strategy for the full scale. However, the re-flashing of the already flashed sludge had no further influence.

3. Thermal hydrolysis of waste activated sludge is a robust pre-treatment process, leading to similar improvements in methane production (exceeding 50\% increases, from 220 to 360 $\mathrm{mL} \mathrm{CH}_{4} / \mathrm{g} \mathrm{VS}_{\text {fed }}$ ) for a wide range of experimental conditions: $140-170^{\circ} \mathrm{C}$ heating and $5-$ 35 min. Therefore an exhaustive control of thermal pre-treatment conditions is not necessary.

4. There is a limiting temperature for thermal hydrolysis processes (always at $200^{\circ} \mathrm{C}$, but also over $170^{\circ} \mathrm{C}$ ) that causes the formation of soluble but non-biodegradable compounds that also lead to lag phases due to methanogens inhibition.

5. The separate digestion of the liquid and solid fractions from thermally pre-treated secondary sludge showed to be a very interesting option in order to optimize the digestion volume, which can be reduced to more than the half, while duplicating the methane production per kilogram of sludge fed to digestion.

6. The simple pressure effect, without heating (performed with $\mathrm{CO}_{2}$ and $\mathrm{CH}_{4}$ ) showed to be an ineffective pre-treatment, both for solubilisation and anaerobic biodegradability improvement.

A final consideration from all the study performed is that for any particular case study, specific studies with the specific sludge are imperative to obtain the real response of that substrate to the proposed process, and check the optimum operating conditions and process consideration. In other words, there is no optimum for any type of sludge and case study. The proposal of the optimum scheme will depend on regulations (disposal, energy and etc.), and on the specific requirements of the particular situation (renovation of existing WWTPs or new construction, digestion needs, available disposal options and etc.). Likewise, the real economic benefit is connected to current market values (capital, disposal and energy costs). 
CHAPTER 10

Future perspectives 

Despite the advances carried out in this thesis towards the worldwide implementation of thermal pre-treatment process for anaerobic digestion improvement, the main drawback of the process significant energy consumption, and still a high quantity of organic matter that is recycled to land after digestion constitute niches for further research. In this regard, the promising results obtained during this thesis suggest that further research should focus on:

Evaluation of the reproducibility of the results obtained for different sludge samples, in order to validate the results here obtained and to analyze the possible influence of sludge characteristics (for example: sludge age) on the response of the process.

* Comparative energetic-economic analysis of the optimum range of experimental conditions concluded in the study. This evaluation allows to quantify the energetic feasibility of the proposed process and the benefit with respect to the conventional AD scenario. A sensitivity analysis would also help to assess the influence of the temperature - time variations on the economic response, in order to identify the economic optimum.

Evaluation of other parameters apart from solubilisation to assess the performance of the thermal hydrolysis and the influence of steam explosion technique, such as particle size. It is expected that rapid decompression due to steam release causes rupture resulting in particle size reduction and, therefore, improving hydrolysis step in anaerobic digestion, and altering sludge rheology. However, contrary results appear in the literature. Regarding the importance of particle size and its influence on dewaterability potential, research study is required in this area, especially due to the impact of pre-treatment conditions and influence on anaerobic digestion.

Deeper insight on the compounds liberated and formed during pre-treatment at mild or severe conditions, such as melanoidins or humic acids.

Evaluation of other benefits of the pre-treatment performed and the influence of changing operation conditions on digestion performance (apart from the biogas increase), such as sludge rheology. The study is certainly relevant considering the significant energy benefit from the thermal pre-treatment technology due to improved sludge rheology, which allows higher loading rates to the digester, destabilizes foam, and improves mass transfer with reduced energy requirement for pumping and mixing.

* Further analysis on biosolids properties, such as dewaterability (which reduces downstream 
transport and processing requirements), micropollutants concentration (key aspect in future regulations) or hygienization (key for land application).

- Comparative global evaluation (energy, cost, digestion performance, biosolids,...) of novel process configurations, such as phase segregation (scheme a) or intermediate thermal hydrolysis (scheme d), in comparison with the conventional thermal hydrolysis schemes (schemes b and c).

\section{a) SDSL}

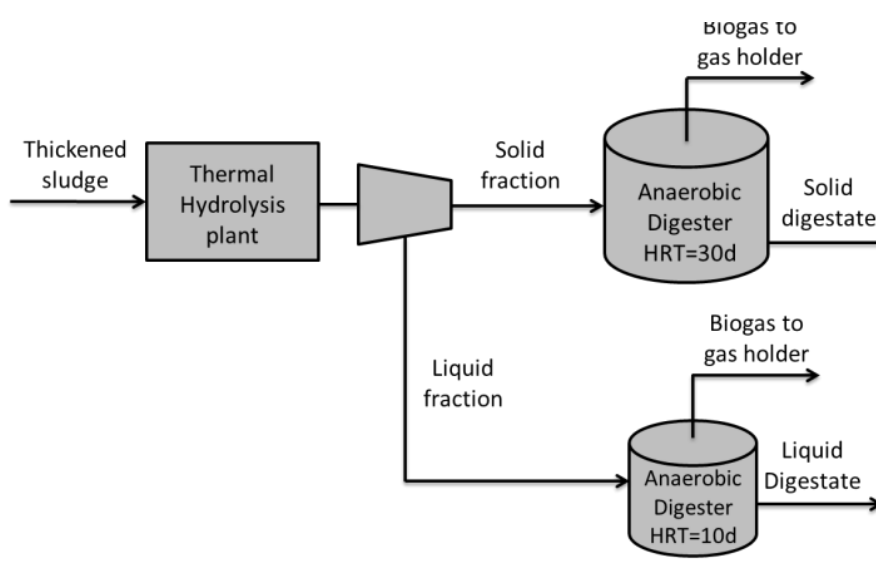

b) THP1

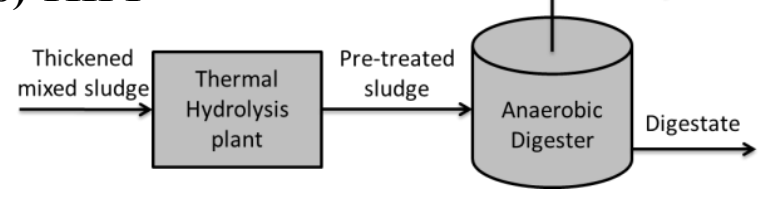

c) THP2 $\quad \begin{array}{r}\text { Biogas to } \\ \text { gas holder }\end{array}$

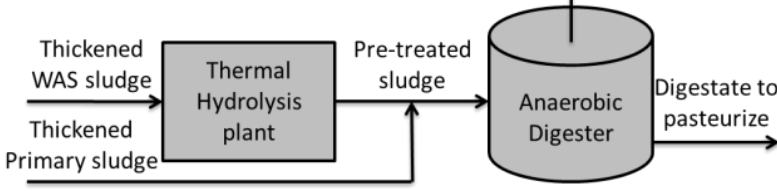

d) ITH

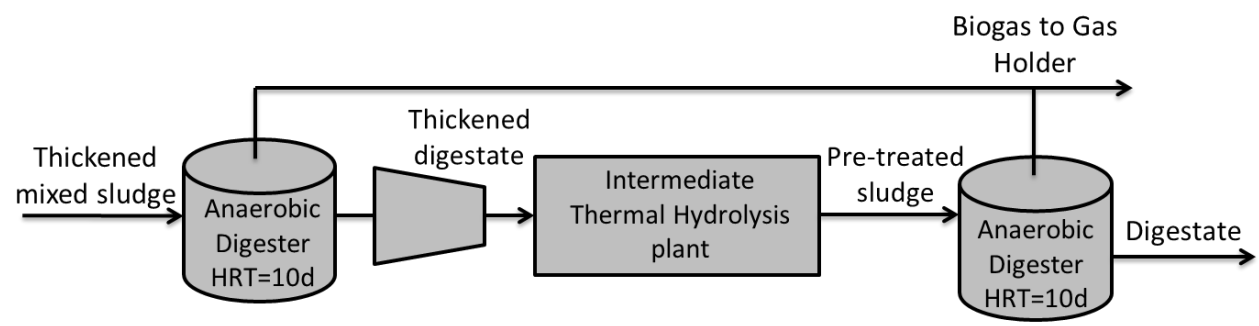

The different schemes proposed are below described:

- Schematic SDLS presents the separate digestion of liquid and solid fractions of thermally pre-treated sludge. Further evaluation study is needed for this configuration, since the evaluation performed in this thesis demonstrated to be an attractive choice for future optimization of overall digestion process with higher methane production and smaller digestion volume leading to a performance in an energy-favorable way.

- Schematics THP1 and THP2 are the most common forms of thermal hydrolysis pretreatments. Their application depends on the final purpose of the pre-treatment - to 
hydrolyze only the secondary sludge (THP2) when the aim is to increase biogas yield and reduce biosolids volume, or to hydrolyze both the primary and the secondary sludge (THP1) when the additional objective is to pasteurize the biosolids. THP1 represents most of the real application of full-scale thermal hydrolysis process, while THP2 presents a more beneficial energy balance (the hydrolysis unit is significantly reduced in size, and the steam demand met with no auxiliary fuel), although, biosolids from THP2 need further pasteurization.

- Schematic ITH is a novel sludge treatment configuration, which consists of an intermediate step of thermal hydrolysis (ITH). The ITH pre-treatment consist of a conventional mesophilic anaerobic digestion followed by thermal pre-treatment and a second stage of mesophilic anaerobic digestion of the resulting stage. After the first digestion stage, the remaining quantity of energy rich sludge could be further subjected to anaerobic digestion with the view of obtaining additional biogas, reducing the sludge volume to be disposed and improving quality of digested cake. A comprehensive study is needed for this thermal pre-treatment configuration due to its perspective in reducing the carbon footprint and leading to more sustainable overall sludge treatment process. 
CHAPTER 11

Curriculum Vitae 



\section{Publications in international journals}

- Optimization of a thermal hydrolysis process for sludge pre-treatment (2017). Sapkaite, I., Barrado, E., Fdz-Polanco, F., Pérez-Elvira, S. I. Journal of Environmental Management 192, 25-30.

- Separate digestion of liquid and solid fractions of thermally pretreated secondary sludge. Assessment and global evaluation (2016). Pérez-Elvira, S. I., Sapkaite, I., FdzPolanco, F. Brazilian Journal of Chemical Engineering 33 (4), 699-704.

- From pre-treatment toward inter-treatment. Getting some clues from sewage sludge biomethanation (2016). Ortega-Martinez, E., Sapkaite, I., Fdz-Polanco, F., Donoso-Bravo, A. Bioresource Technology 212, 227-235.

- Evaluation of thermal steam-explosion key operation factors to optimize biogas production from biological sludge (2015). Pérez-Elvira, S. I., Sapkaite, I., Fdz-Polanco, F. Water Science \& Technology 72 (6), 937-945.

- Thermal pretreatment and hydraulic retention time in continuous digesters fed with sewage sludge: Assessment using the ADM1 (2013). Souza, T.S.O., Ferreira, L.C., Sapkaite, I., Perez-Elvira, S.I., Fdz-Polanco, F. Bioresource Technology 148, 317-324.

Participation in congress and courses

\section{Latin American Workshop and Symposium on Anaerobic Digestion}

* Sapkaite I, Perez-Elvira S.I, Fdz-Polanco F. Comparison of scenarios combining thermal hydrolysis and digestion of sludge. Economic global balance. 23-27 October 2016, Cuzco, Peru (Oral presentation).

* Sapkaite I, Perez-Elvira S.I, Fdz-Polanco F. The effect of Intermediate Thermal Hydrolysis on sludge digestion process efficiency. 23-27 October 2016, Cuzco, Peru (Oral presentation).

\section{4th World Congress on Anaerobic Digestion}

* Sapkaite I, Fdz-Polanco F, Perez-Elvira S.I. Thermal Hydrolysis of Sludge over a limiting temperature. Effect on prediction parameters. 15-18 November 2015, Viña del Mar, Chile (Oral presentation).

\section{Latinamerican Symposium of Anaerobic Digestion}

Perez-Elvira S.I, Sapkaite I, Fdz-Polanco F. Separate digestion of liquid and solid fractions of thermally pretreated secondary sludge. Assessment and global evaluation. 24-27 November 2014, La Habana, Cuba (Poster). 
Pérez-Elvira S.I, Sapkaite I, Fdz-Polanco F. Evaluation of thermal steam-explosion key operation factors to optimize biogas production from biological sludge. 24-27 November 2014, La Habana, Cuba (Oral Presentation).

* Kist D.L, Cano R, Sapkaite I, Pérez-Elvira S.I, Fdz-Polanco F, Monteggia L.O. Effects of Thermal Steam Explosion Pre-treatment on Water Hyacinth Anaerobic Digestion. 24-27 November 2014, La Habana, Cuba (Oral Presentation).

* Kist D.L, Cano R, Sapkaite I, Pérez-Elvira S.I, Fdz-Polanco F, Monteggia L.O. Ultrasound Pretreatment of Macrophytes for Enhanced Biogas Production. 24-27 November 2014, La Habana, Cuba (Oral Presentation).

\section{3th World Congress on Anaerobic Digestion: Recovering (bio) resources for the world}

Pérez-Elvira S.I, Sapkaite I, Ferreira L.C, Fdz-Polanco F. Thermal hydrolysis pre-treatment of biosolids: A review on commercial processes. 25-28 June 2013, Santiago de Compostela, Spain (Poster).

\section{Short courses}

\section{Specialized Course: Reuse climate change and anaerobic digestion}

Assistant. 14th World Congress on Anaerobic Digestion, San Pedro de Atacama, Chile, 10-13 November 2015.

\section{Pre-Conference Specialised Short Course: Innovative Sludge Pre-treatments}

Assistant. School of Industrial Engineering, University of Valladolid, Valladolid, Spain, 24 June 2013.

\section{Stays abroad}

June - October 2016

Research stay at University of the Republic, Montevideo, Uruguay. Professor Liliana Borzacconi. 
